ESCOLA POLITÉCNICA DA UNIVERSIDADE DE SÃO PAULO DEPARTAMENTO DE ENGENHARIA DE TRANSPORTES

MÁRIO ALEXANDRE DE ABREU

ANÁLISE DA QUALIDADE DOS DADOS GPS: ESTUDO DE CASO DA ESTAÇÃO DE CANANÉIA 
MÁRIO ALEXANDRE DE ABREU

\section{ANÁLISE DA QUALIDADE DOS DADOS GPS: ESTUDO DE CASO DA ESTAÇÃO DE CANANÉIA.}

Dissertação apresentada à Escola Politécnica da Universidade de São Paulo para obtenção do título de Mestre em Engenharia.

São Paulo 
MÁRIO ALEXANDRE DE ABREU

\title{
ANÁLISE DA QUALIDADE DOS DADOS GPS: ESTUDO DE CASO DA ESTAÇÃO DE CANANÉIA.
}

\author{
Dissertação apresentada à Escola Politécnica da \\ Universidade de São Paulo para obtenção do título \\ de Mestre em Engenharia. \\ Área de Concentração: \\ Engenharia de Transportes \\ Orientador: \\ Prof. Dr. Edvaldo Simões da Fonseca Junior
}

São Paulo 
Este exemplar foi revisado e alterado em relação à versão original, sob responsabilidade única do autor e com a anuência de seu orientador.

São Paulo, 04 de maio de 2007.

Assinatura do autor

Mário Alexandre de Abreu

Assinatura do orientador

FICHA CATALOGRÁFICA

Abreu, Mário Alexandre de

Análise da qualidade dos dados GPS: estudo de caso da estacão de Cananéia / M.A. de Abreu. -- ed. rev. -- São Paulo, 2007. $180 \mathrm{p}$.

Dissertação (Mestrado) - Escola Politécnica da Universidade de São Paulo. Departamento de Engenharia de Transportes.

1.Geodésia 2.Geodésia espacial 3.Sistema de posicionamento global I.Universidade de São Paulo. Escola Politécnica. Departamento de Engenharia de Transportes II.t. 
Aos meus queridos pais Magno (in memorian) e Fátima pelo constante incentivo e à minha amada esposa Natacha pelo companheirismo e dedicação. 


\section{AGRADECIMENTOS}

Ao meu orientador Prof. Dr. Edvaldo Simões da Fonseca Junior pelo incentivo, apoio e confiança;

A CAPES pela concessão de bolsa durante o primeiro ano desta pesquisa;

Ao Dr. Carlos Augusto de Sampaio França e Prof. Dr. Paulo de Oliveira Camargo pelas sugestões apresentadas durante o exame de qualificação, que muito contribuíram para esta pesquisa;

Aos Professores Dr. Denizar Blitzkow e Dr. Nicola Paciléo Netto pelo incentivo e aprendizado nestes anos de convivência;

À Coordenação de Geodésia do IBGE e ao IO-USP pela cessão dos dados utilizados nesta pesquisa;

À Dra . Sônia Maria Alves Costa por autorizar a utilização do programa Bernese e pelo auxílio constante;

Ao amigo Rodrigo Affonso de Albuquerque Nóbrega pelo grande incentivo para o início deste trabalho;

Aos amigos Daniel Silva Costa e Flávio Guilherme Vaz de Almeida pelas discussões e constante colaboração;

Ao amigo Alberto Luís da Silva pelo auxílio no entendimento do programa Bernese além das discussões durante o trabalho;

Ao amigo Newton José de Moura Júnior pela ajuda no desenvolvimento dos shell em LINUX; 
À Ana Cristina Oliveira Cancoro de Matos pelo auxílio no desenvolvimento dos scripts em UNIX e pela ajuda e interesse nesta pesquisa;

À Maria Cristina Barboza Lobianco pela revisão do Resumo e do Abstract, além da cooperação em alguns momentos críticos;

Ao amigo André Rodrigues pelas discussões sobre o TEQC;

Aos amigos Rodrigo Gonçales e Andrezza Lucas pela amizade e por terem proporcionado que minhas estadias em São Paulo fossem mais agradáveis;

Ao amigo Elivagner Barros de Oliveira pelo incentivo e cooperação.

Aos amigos de POLI: Claudomiro Santos, Marcos Almir de Oliveira, Jefferson Rocco e Adilson Haroldo Piveta pela cooperação;

Aos amigos de CGED, em especial ao Wagner Carrupt Machado, ao Daniel Goldani, ao Rafael Santos Genro, ao Marco Aurélio de Almeida Lima e ao Jardel Aparecido Fazan,

Às funcionárias da Biblioteca da Engenharia Civil, Sarah Lorenzon Pereira e Silvia Regina Saran Della Torre pela revisão das Referências e pela preparação da ficha catalográfica;

A todos que direta ou indiretamente contribuíram para o sucesso deste trabalho. 


\section{RESUMO}

Na Geodésia, quando se deseja determinar coordenadas com exatidão e precisão, faz-se uso do posicionamento relativo. Esta técnica consiste no emprego de dois ou mais receptores GPS onde um receptor permanece sobre um ou mais pontos de coordenadas conhecidas (base) e um ou mais receptores (rover) são colocados sobre os pontos a serem determinados. Para auxiliar e aumentar a produtividade dos usuários que utilizam o posicionamento relativo foram criados os Sistemas de Controle Ativo (SCA), que permitem ao usuário empregar apenas um receptor para realizar o posicionamento relativo, desde que dados coletados simultaneamente de uma estação contínua, pertencente a uma rede ativa, estejam disponíveis. No Brasil, a rede ativa, gerenciada pelo IBGE, é materializada pela RBMC - Rede Brasileira de Monitoramento Contínuo do Sistema GPS. Os dados de 24 estações distribuídas por todo o território nacional são coletados ininterruptamente e disponibilizados para os usuários. Devido ao grande aumento da utilização das redes de monitoramento contínuo, é de suma importância que as observáveis das estações passem por um controle de qualidade, assegurando confiabilidade aos dados coletados. Neste trabalho é apresentada uma análise detalhada dos indicativos de qualidade dos dados da estação NEIA (Cananéia/SP), pertencente a RBMC, referente ao período compreendido entre janeiro de $2002 \mathrm{e}$ abril de 2006, bem como da variação temporal de suas coordenadas (latitude, longitude e altura geométrica), quando comparadas com as coordenadas fiduciais da estação. Estas análises foram realizadas com base nos resultados de processamento obtidos com o uso dos seguintes programas: TEQC, BERNESE V. 5.0 e pelo serviço de processamento on-line AUSPOS.

Palavras-chave: Geodésia. Análise da qualidade. Processamento de dados. GPS. 


\begin{abstract}
In Geodesy, when the determination of coordinates with great accuracy and precision is desired, relative positioning is used. This technique consists of the use of the two or more receivers, where a receiver is placed on a station of known coordinates (base) and one or more remote receivers (rover) is placed on the stations to be determines. To help and increase the productivity of the users that use relative positioning, had been created the Control Active Systems (SCA), that allow the use of only one receiver by the user to carry out the relative positioning, provided that the data collected simultaneously from a continuous station of an active network is available. In Brazil, the active network is materialized by the RBMC - Brazilian Network of Continuous Monitoring of GPS, managed by the IBGE. Data of 24 stations distributed throughout the country is collected uninterruptedly and made available for the users. Due to the great increase of the use of the networks of continuous monitoring, it is of high importance that the observations pass through a quality control, assuring trustworthiness to the collected data. In this work is presented a detailed analysis of the data quality of station NEIA (Cananéia/São Paulo State/Brazil), belonging to the RBMC, referring to the period between January 2002 and May 2006, and the secular variation of its coordinates (latitude, longitude and geometric height), when compared with the fiducials coordinates of this station. These analyses had been carried out based on the results obtained by the processing with the following softwares: TEQC, BERNESE V. 5.0 and the AUSPOS on-line processing service.
\end{abstract}

Keywords: Geodesy. Quality analysis. Data processing. GPS. 


\section{LISTA DE FIGURAS}

Figura 1: Estações do segmento de controle do GPS .................................... 34

Figura 2: Estrutura dos sinais GPS ........................................................... 36

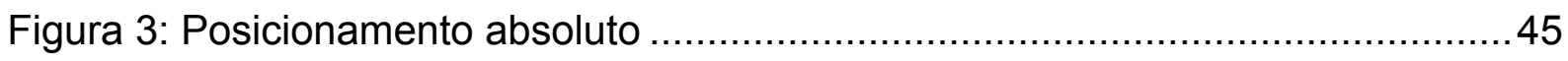

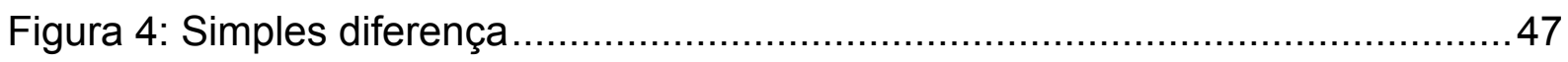

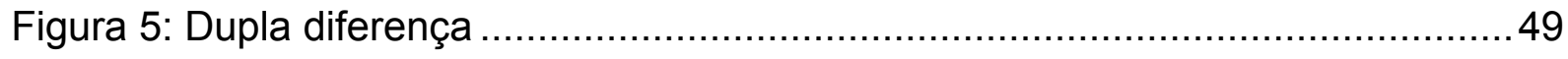

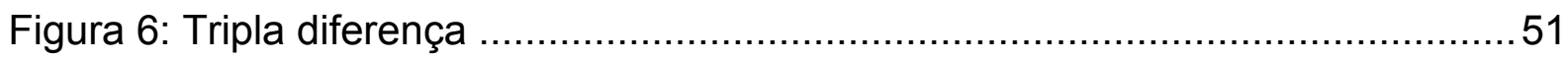

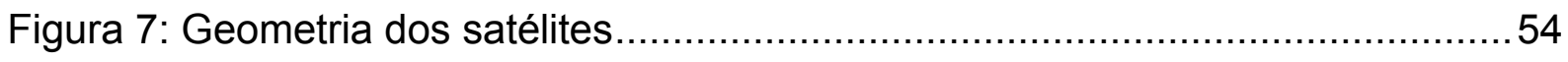

Figura 8: Camadas da Atmosfera Terrestre .................................................. 58

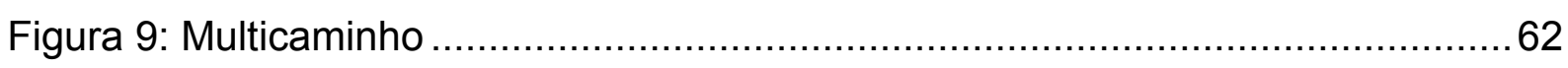

Figura 10: Fluxograma da utilização das DD de fase da onda portadora na resolução das ambigüidades.................................................. 72

Figura 11: Distribuição atual das estações da RBMC ..................................... 84

Figura 12: Receptor e computador da estação NEIA ........................................ 85

Figura 13: Vista frontal do pilar e antena da estação NEIA ................................. 86

Figura 14: Vista lateral esquerda do pilar e antena da estação NEIA ...................... 86

Figura 15: Vista lateral direita do pilar e antena da estação NEIA ......................... 87

Figura 16: Exemplo de gráfico de representação temporal .................................. 101

Figura 17: Exemplos de séries temporais ideais ........................................ 103

Figura 18: Desenho esquemático ou Boxplot ................................................ 107

Figura 19: Histograma do número de horas coletadas por sessão no $1^{\circ}$ período... 111

Figura 20: Histograma do número de horas coletadas por sessão no $2^{\circ}$ período... 112

Figura 21: Histograma do número de observações coletadas por sessão no $1^{\circ}$ período......................................................................... 113

Figura 22: Histograma do número de observações coletadas por sessão no

$2^{\circ}$ período.......................................................................... 114

Figura 23: Histograma do número de perdas de ciclos por sessão no $1^{\circ}$ período. . 116

Figura 24: Histograma do número de perdas de ciclos por sessão no $2^{\circ}$ período. . 116

Figura 25: Boxplots para MP1 para os dois períodos........................................ 120

Figura 26: Boxplots para MP2 para os dois períodos........................................120

Figura 27: Gráfico dos valores calculados para MP1 e MP2 no $1^{\circ}$ período,

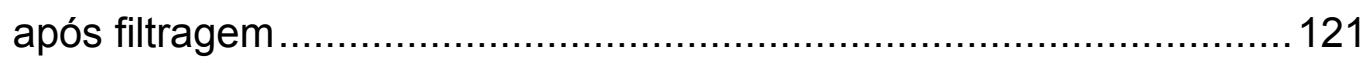


Figura 28: Gráfico dos valores calculados para MP1 e MP2 no $2^{\circ}$ período, após filtragem

Figura 29: Gráfico das diferenças em latitude na semana1 …............................ 127

Figura 30: Gráfico das diferenças em longitude na semana1 ..............................127

Figura 31: Gráfico das diferenças em altura geométrica na semana1 ..................128

Figura 32: Gráfico das diferenças em latitude na semana2. ............................... 129

Figura 33: Gráfico das diferenças em longitude na semana2 .............................130

Figura 34: Gráfico das diferenças em altura geométrica na semana2. .................. 130

Figura 35: Gráfico das diferenças em latitude na semana3 ................................. 132

Figura 36: Gráfico das diferenças em longitude na semana3. ............................. 132

Figura 37: Gráfico das diferenças em altura na semana3..................................133

Figura 38: Gráfico das diferenças diárias em latitude para os dois períodos. ......... 135

Figura 39: Gráfico das diferenças diárias em longitude para os dois períodos. ...... 136

Figura 40: Gráfico das diferenças diárias em altura geométrica para os

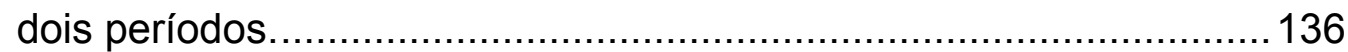

Figura 41: Boxplot das diferenças diárias em latitude para os dois períodos.......... 142

Figura 42: Gráfico das diferenças diárias em latitude após filtragem ..................... 142

Figura 43: Boxplot das diferenças diárias em longitude para os dois períodos....... 144

Figura 44: Gráfico das diferenças diárias em longitude após filtragem ...................145

Figura 45: Boxplot das diferenças diárias em altura geométrica para os

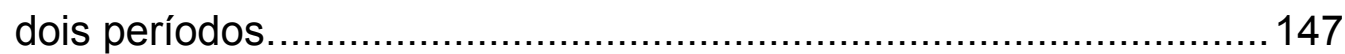

Figura 46: Gráfico das diferenças diárias em altura geométrica após filtragem ......147

Figura 47: Boxplot das diferenças diárias em latitude para os dois períodos..........151

Figura 48: Gráfico das diferenças diárias em latitude utilizando o

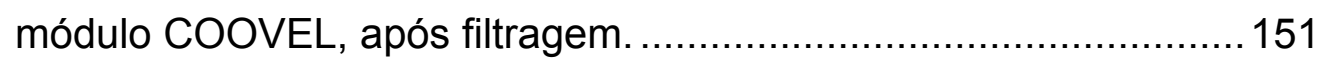

Figura 49: Boxplot das diferenças diárias em longitude para os dois períodos.......153

Figura 50: Gráfico das diferenças diárias em longitude utilizando o módulo COOVEL, após filtragem.............................................154

Figura 51: Boxplot das diferenças diárias em altura geométrica para os dois períodos.

Figura 52: Gráfico das diferenças diárias em altura geométrica utilizando o

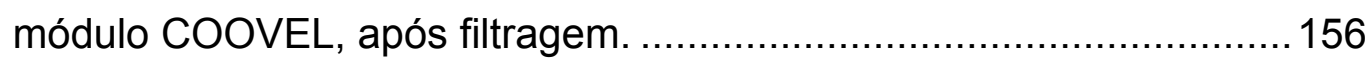

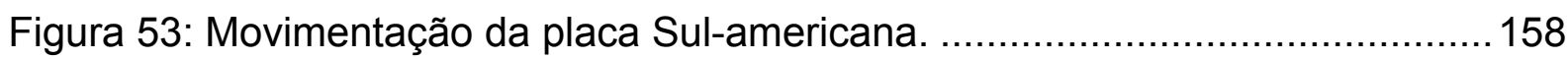

Figura 54: Vetor resultante do deslocamento................................................. 159 
Figura 55: Gráfico das diferenças semanais em latitude (IBGE) ......................... 162

Figura 56: Gráfico das diferenças semanais em longitude (IBGE)...................... 162

Figura 57: Gráfico das diferenças semanais em altura geométrica (IBGE)............ 163

Figura 58: Gráfico das diferenças semanais em latitude (DGFI)..........................165

Figura 59: Gráfico das diferenças semanais em longitude (DGFI)....................... 165

Figura 60: Gráfico das diferenças semanais em altura geométrica (DGFI).............166 


\section{LISTA DE QUADROS}

Quadro 1 - Exatidão das efemérides 44

Quadro 2 - Fontes e efeitos dos erros envolvidos nas observáveis GPS .56

Quadro 3 - Total de horas coletadas por sessão. 112

Quadro 4 - Total de observações coletadas por sessão 114

Quadro 5 - Valores de perdas de ciclos 115

Quadro 6 - Valores calculados para MP1. 118

Quadro 7 - Valores calculados para MP2. 118

Quadro 8 - Valores calculados para eliminação de outliers em MP1 e MP2 ...... 119

Quadro 9 - Média e desvio padrão das diferenças da semana1 128

Quadro 10 - Média e desvio padrão das diferenças da semana2 131

Quadro 11 - Média e desvio padrão das diferenças da semana3 133

Quadro 12 - Tendências Anuais Calculadas 137

Quadro 13 - Média e desvio padrão das linhas de base (2002) 139

Quadro 14 - Média e desvio padrão das linhas de base (2004) 139

Quadro 15 - Valores das diferenças diárias em latitude 141

Quadro 16 - Valores calculados para eliminação de outliers em latitude 141

Quadro 17 - Valores das diferenças diárias em longitude 143

Quadro 18 - Valores calculados para eliminação de outliers em longitude . 144

Quadro 19 - Valores das diferenças diárias em altura geométrica 146

Quadro 20 - Valores calculados para eliminação de outliers em altura geométrica

Quadro 21 - Diferenças em latitude, longitude e altura geométrica após a filtragem .

Quadro 22 - Deslocamentos anuais calculados

Quadro 23 - Valores das diferenças diárias em latitude utilizando o módulo COOVEL .

Quadro 24 - Valores calculados para eliminação de outliers em latitude 150

Quadro 25 - Valores das diferenças diárias em longitude 152

Quadro 26 - Valores calculados para eliminação de outliers em longitude . 153

Quadro 27 - Valores das diferenças diárias em altura geométrica. 154 
Quadro 28 - Valores calculados para eliminação de outliers em altura geométrica

Quadro 29 - Diferenças em latitude, longitude e altura geométrica utilizando o

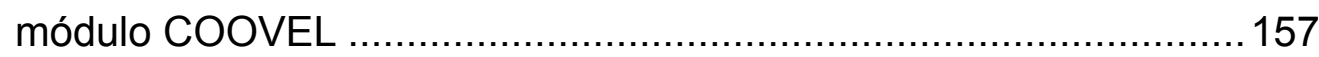

Quadro 30 - Deslocamentos anuais calculados utilizando o módulo COOVEL...... 157

Quadro 31 - Comparação entre os deslocamentos anuais calculados

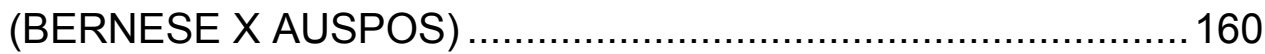

Quadro 32 - Comparação entre os deslocamentos anuais calculados (Nesta pesquisa (BERNESE) X IBGE) 163

Quadro 33 - Comparação entre os deslocamentos anuais calculados (Nesta pesquisa (BERNESE) X DGFI) 


\section{LISTA DE TABELAS}

Tabela 2.1 - Características e combinações dos sinais GPS ..............................69

Tabela 4.1 - Comprimento das linhas de base utilizadas ............................... 125 


\section{LISTA DE ABREVIATURAS E SIGLAS}

$\begin{array}{ll}\text { AFB } & \text { Air Force Base } \\ \text { AG } & \text { Auto Gipsy } \\ \text { AII } & \text { Accuracy Improvement Initiative } \\ \text { ARP } & \text { Antenna Reference Point } \\ \text { AS } & \text { Anti-Spoofing } \\ \text { ASCII } & \text { American Standard Code for Information Interchange } \\ \text { AUSPOS } & \text { Australian Surveying and Land Information Group's Online GPS } \\ \text { AUTONAV } & \text { Processing Service } \\ \text { C/A } & \text { Autonomously Navigate } \\ \text { CDMA } & \text { Coarse-Acquisition } \\ \text { CGED } & \text { Code Division Multiple Access } \\ \text { CIGNET } & \text { Coordenação de Geodésia } \\ \text { Código P } & \text { Cooperative International GPS Network } \\ \text { CPTEC/INPE } & \text { Centro de Previsão de Tempo e Estudos Climáticos / Instituto } \\ & \text { Nacional de Pesquisas Espaciais } \\ \text { CSRS } & \text { Canadian Spatial Reference System } \\ \text { CTP } & \text { Conventional Terrestrial Pole } \\ \text { DD } & \text { Dupla diferença } \\ \text { DGFI } & \text { Deutsches Geodätisches Forschungsinstitut } \\ \text { DoD } & \text { U. S. Department of Defense } \\ \text { DOP } & \text { Dilution of Precision } \\ \text { EGNOS } & \text { European Geostationary Navigation Overlay Service } \\ \text { EP-USP } & \text { Escola Politécnica da Universidade de São Paulo } \\ \text { ESA } & \text { European Space Agency } \\ \text { FAA } & \text { Federal Aviation Administration } \\ \text { FARA } & \text { Fast Ambiguity Resolution Approach } \\ \text { FASF } & \text { Fast Ambiguity Search Filter } \\ \text { FNMA } & \text { Fundo Nacional do Meio Ambiente } \\ \text { GCC } & \text { Galileo Control Center } \\ & \end{array}$




$\begin{array}{ll}\text { GDOP } & \text { Diluição da precisão resultante da combinação de PDOP e TDOP } \\ \text { GIOVE-A } & \text { Galileo In-Orbit Validation Element } \\ \text { GIPSY-OASIS } & \begin{array}{l}\text { GPS-Inferred Positioning System and Orbit Analysis SImulation } \\ \text { Software }\end{array} \\ \text { GLONASS } & \text { Global'naya Navigatsionnay Sputnikovaya Sistema } \\ \text { GNSS } & \text { Global Navigation Satellite System } \\ \text { GPS } & \text { Global Positioning System } \\ \text { GSS } & \text { Galileo Sensor Stations } \\ \text { HDOP } & \text { Diluição da precisão em planimetria } \\ \text { HP } & \text { High Precision } \\ \text { IBGE } & \text { Fundação Instituto Brasileiro de Geografia e Estatística } \\ \text { IERS } & \text { International Earth Rotation and Reference Systems Service } \\ \text { IGR } & \text { Prefixo para indicar as efemérides rápidas disponibilizadas pelo } \\ \text { IGS } & \text { IGS } \\ \text { IGU } & \text { International GNSS Service } \\ \text { INPE } & \text { Prefixo para indicar as efemérides ultra-rápidas disponibilizadas } \\ \text { INCRA } & \text { pelo IGS } \\ \text { IO-USP } & \text { Instituo Nacional de Pesquisas Espaciais } \\ \text { ITRF } & \text { Instituto Nacional de Colonização e Reforma Agrária } \\ \text { ITRF2000 } & \text { Instituto Oceanográfico da Universidade de São Paulo } \\ \text { JPL } & \text { International Terrestrial Reference Frame } \\ \text { JPO } & \text { International Terrestrial Reference Frame - época 2000 } \\ \text { L-All } & \text { Jet Propulsion Laboratory } \\ \text { LAMBDA } & \text { Joint Program Office } \\ \text { LI } & \text { Legacy Accuracy Improvement Initiative } \\ \text { LLR } & \text { Least Squares Ambiguity Decorrelation Approach } \\ \text { LS } & \text { Limite inferior } \\ \text { MCS } & \text { Lunar Laser Range } \\ \text { MIT } & \text { Modified Least Squares Ambiguity Decorrelation Approach } \\ \text { MLAMBDA } & \end{array}$




$\begin{array}{ll}\text { MMQ } & \text { Método dos Minimos Quadrados } \\ \text { MVC } & \text { Matriz Variância-covariância } \\ \text { NAD83 } & \text { North American Datum 1983 } \\ \text { NASA } & \text { National Aeronautics and Space Administration } \\ \text { NAVCEN } & \text { Navigation Center } \\ \text { NAVSTAR } & \text { Navigation STAR } \\ \text { NGA } & \text { National Geospatial-intelligency Agency } \\ \text { NGS } & \text { US National Geodetic Survey } \\ \text { NNSS } & \text { Navy Navigation Satellite System } \\ \text { NRCAN } & \text { Natural Resources Canada } \\ \text { OCS } & \text { Operational Control Segment } \\ \text { ORMS } & \text { Orbiter and Radio Metric Systems Group } \\ \text { OTF } & \text { On-the-fly } \\ \text { PDF } & \text { Portable Document Format } \\ \text { PDOP } & \text { Diluição da precisão em posicionamento tridimensional } \\ \text { PPP } & \text { Posicionamento Preciso por Ponto } \\ \text { PPS } & \text { Precise Positioning Service } \\ \text { PRN } & \text { Pseudo Randon Noise } \\ \text { RBMC } & \text { Rede Brasileira de Monitoramento Contínuo do Sistema GPS } \\ \text { RDOP } & \text { Diluição da precisão relativa entre 2 pontos } \\ \text { RINEX } & \text { Receiver Independent Exchange Format } \\ \text { SA } & \text { Selective Availability } \\ \text { SCA } & \text { Sistema de Controle Ativo } \\ \text { SCOUT } & \text { Scripps Coordinate Update Tool } \\ \text { SD } & \text { Selective Denial } \\ \text { SIRGAS } & \text { Sistema de Referência Geocêntrico para as Américas } \\ \text { SIRGAS2000 } & \text { Sistema de Referência Geocêntrico para as Américas - época } \\ \text { SLR } & \text { 2000.4 } \\ \text { SOPAC } & \text { Satellite Laser Range } \\ \text { SP } & \text { Scripps Orbit and Permanent Array Center } \\ \text { SPS } & \text { Standard Precision } \\ & \\ \text { Stanitioning System }\end{array}$


SVN Space Vehicle Number

TDOP Diluição da precisão para determinação de tempo

TEC Total Electron Content

TEQC Translate, Edit, Quality Check

UE União Européia

UERE User Equivalent Range Error

UNAVCO University NAVSTAR Consortium

VDOP Diluição da precisão em altimetria

VLBI Very Long Baseline Interferometry

WAAS Wide Area Augmentation System 


\section{LISTA DE SIGLAS}

$\begin{array}{ll}\varphi & \text { Latitude } \\ \mathrm{f}_{0} & \text { Freqüência fundamental do GPS igual a 10,23 MHz } \\ \mathrm{h} & \text { Altura geométrica } \\ \lambda & \text { Comprimento de onda } \\ \lambda & \text { Longitude } \\ \rho & \text { Distância geométrica } \\ \sigma_{\mathrm{p}} & \text { Desvio padrão do posicionamento } \\ \sigma_{\mathrm{r}} & \text { Desvio padrão da observação } \\ (\mathrm{X}, \mathrm{Y}, \mathrm{Z}) & \text { Coordenadas cartesianas } \\ \text { Código Y } & \text { Código P criptografado } \\ \mathrm{GAMIT} & \text { Programa de processamento de dados GPS desenvolvido pelo MIT } \\ \text { L1 } & \text { Onda portadora do GPS de freqüência igual a 1575,42 MHz } \\ \text { L2 } & \text { Onda portadora do GPS de freqüência igual a 1227,60 MHz } \\ \text { L2C } & \text { Código inserido na onda portadora L2 do GPS } \\ \text { L5 } & \text { Onda portadora do GPS de freqüência igual a 1176,45 MHz } \\ \mathrm{N} & \text { Norte } \\ \text { NO } & \text { Noroeste } \\ \mathrm{O} & \text { Oeste } \\ \text { V } & \text { Volume }\end{array}$




\section{SUMÁRIO}

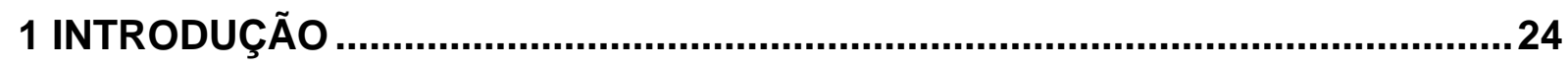

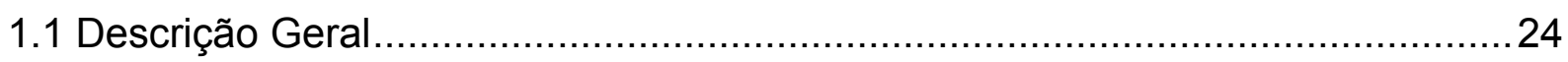

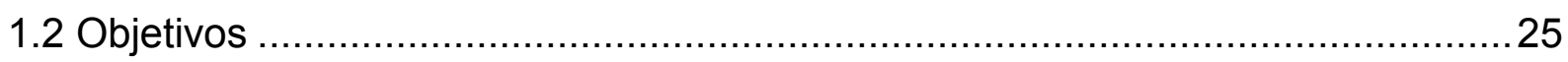

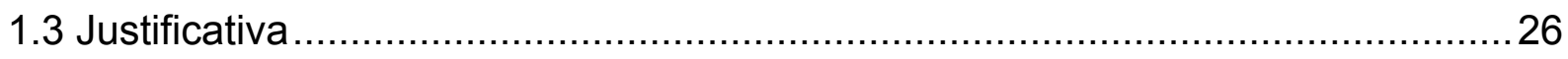

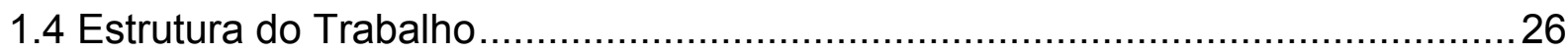

2 SISTEMAS DE POSICIONAMENTO GLOBAL POR SATÉLITE .........................28

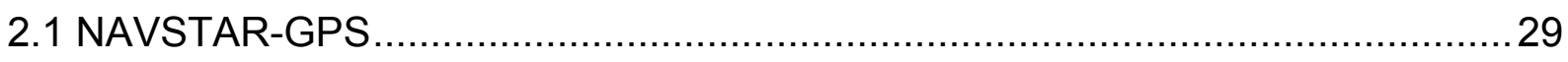

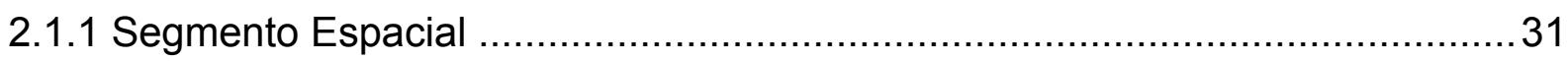

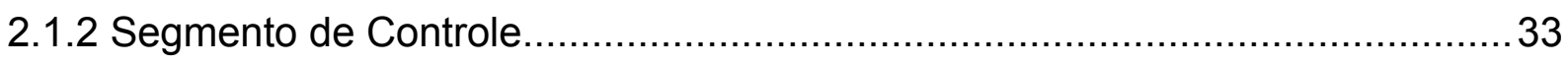

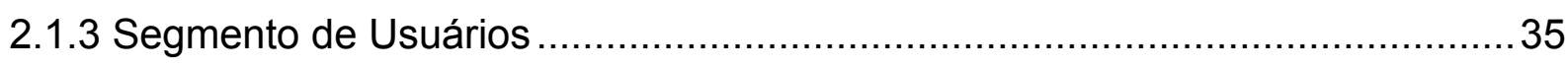

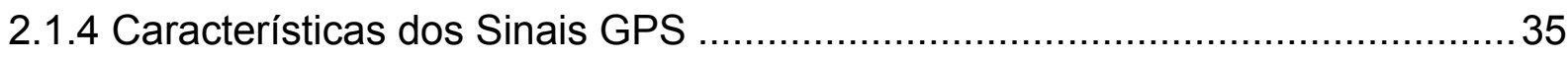

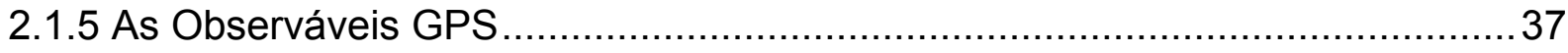

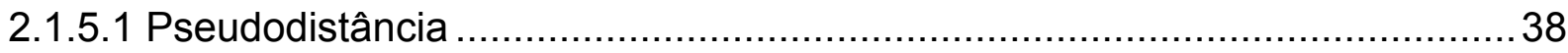

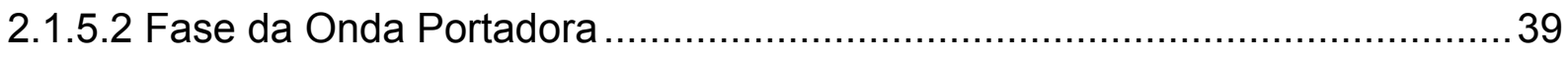

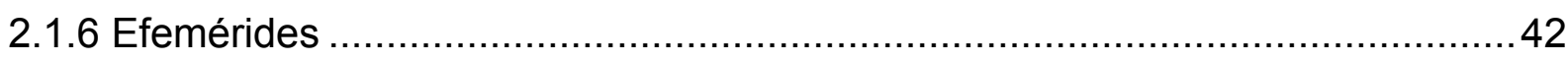

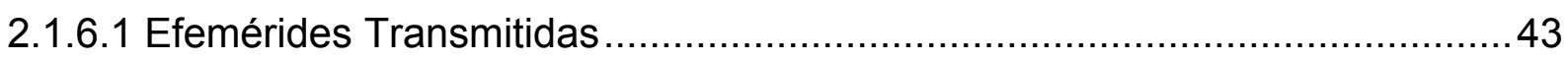

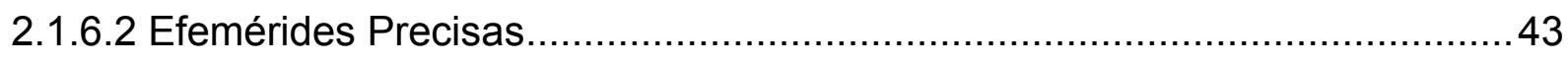

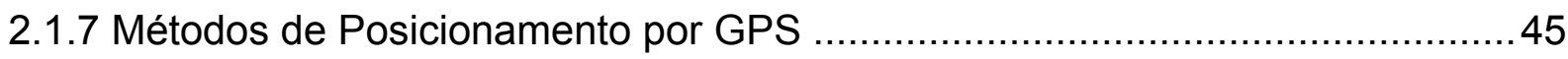

2.1.8 Combinações Lineares entre as Observáveis GPS .....................................46

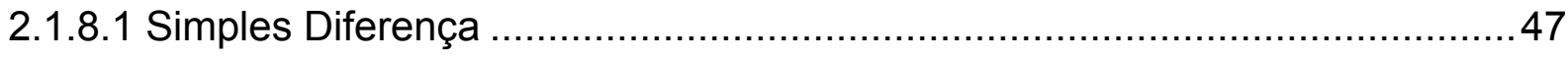

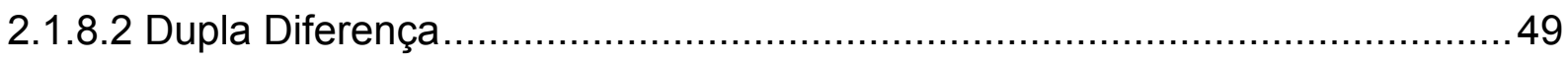

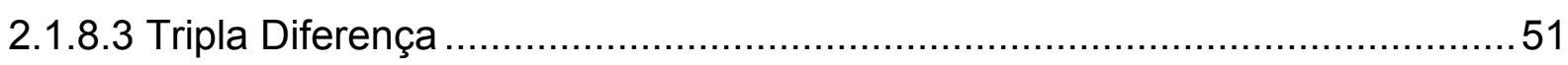

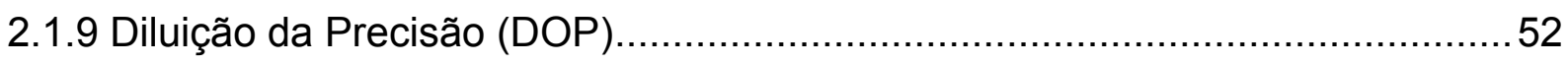

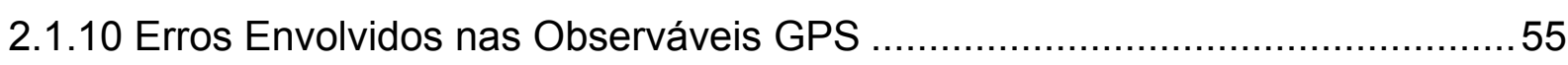

2.1.10.1 Efeitos Relacionados com a Propagação do Sinal ...................................57

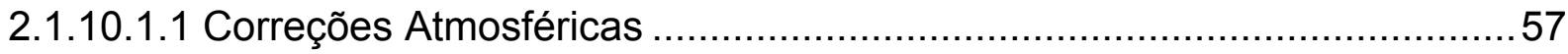

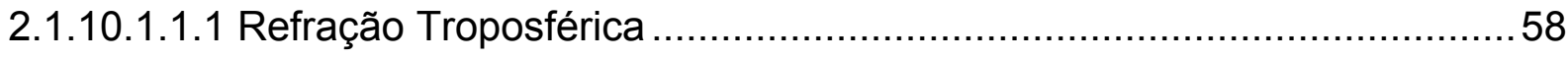

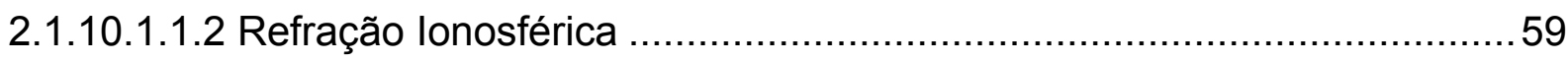

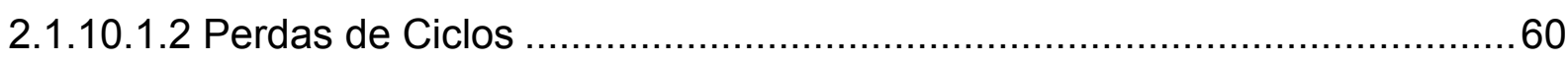

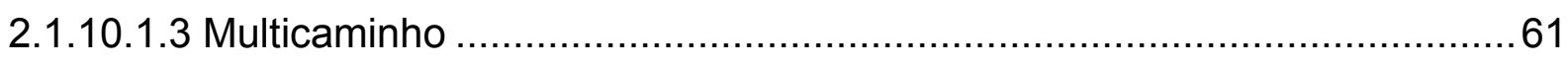

2.1.10.2 Correções Geofísicas Relacionadas com a Estação...................................63 


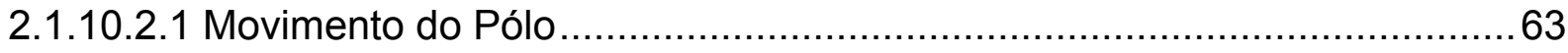

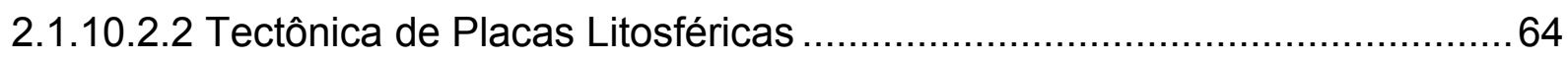

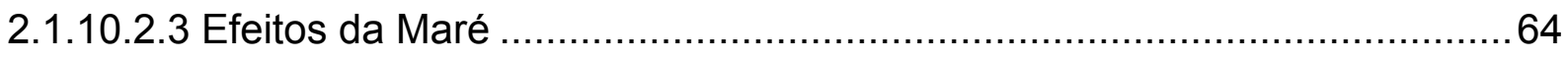

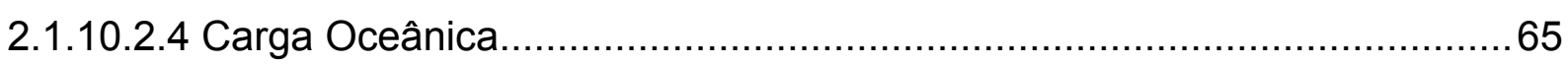

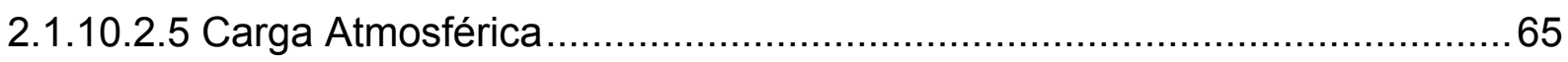

2.1.10.3 Erros Relacionados com o Receptor e a Antena.....................................66

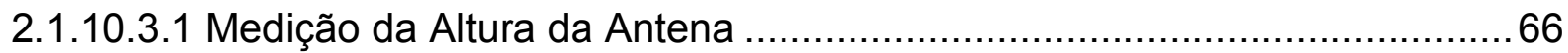

2.1.10.3.2 Erro do Relógio do Receptor (Deriva do Relógio) ..................................67

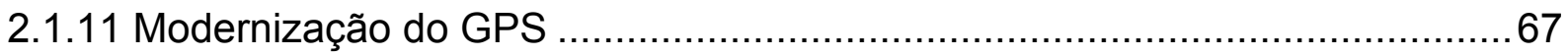

2.1.12 Métodos de Resolução da Ambigüidade ...............................................70

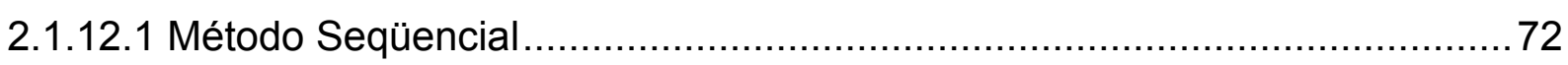

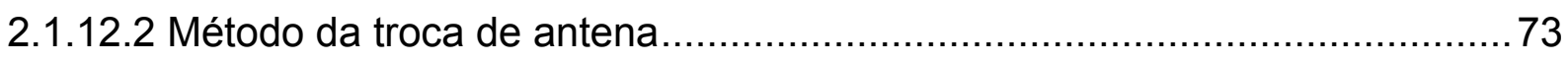

2.1.12.3 Combinações lineares entre as portadoras ...........................................73

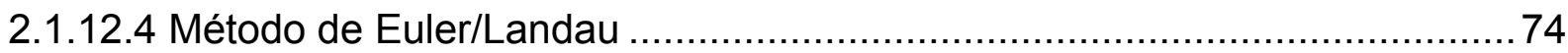

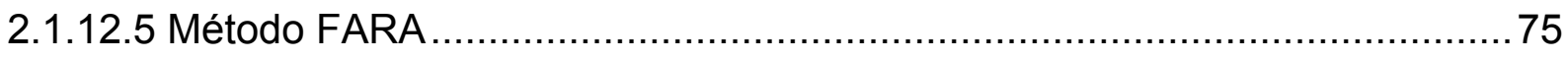

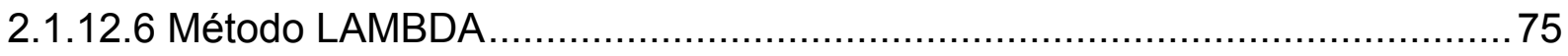

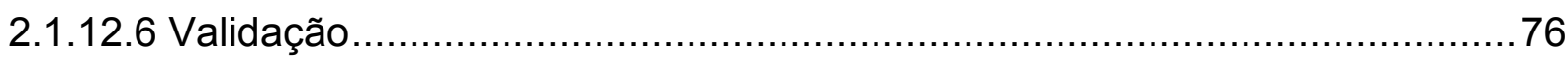

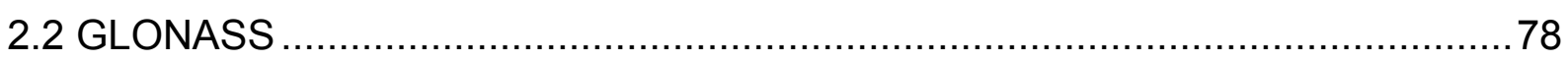

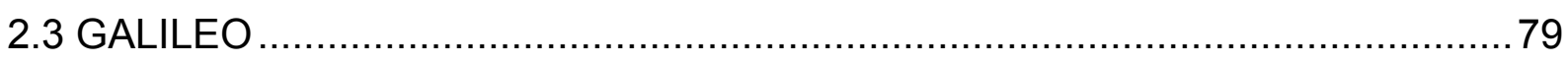

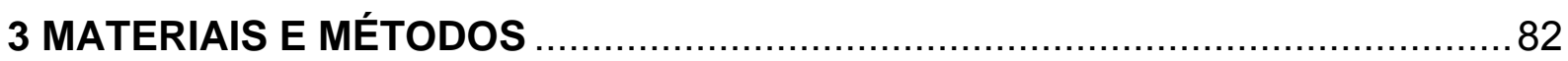

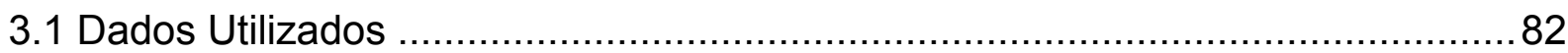

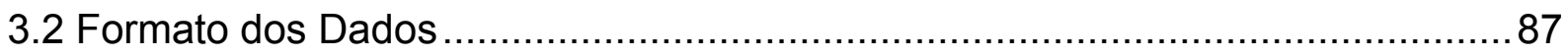

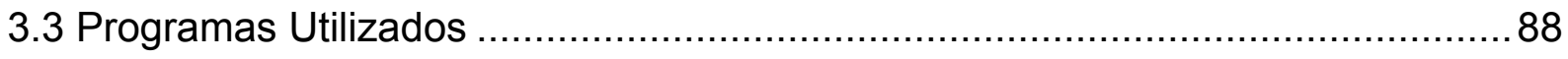

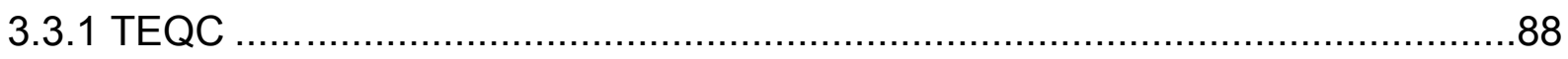

3.3.1.1 Controle de Qualidade Utilizando o TEQC ................................................. 88

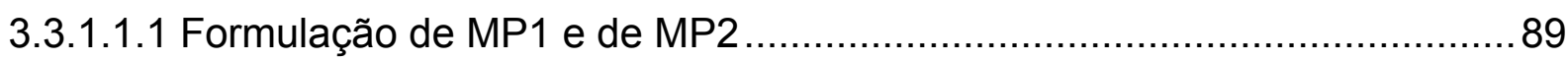

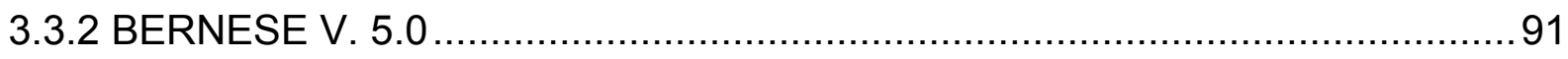

3.3.3 Serviços de Processamento On-line ..........................................................94

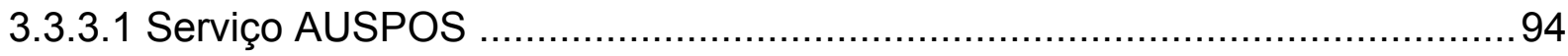

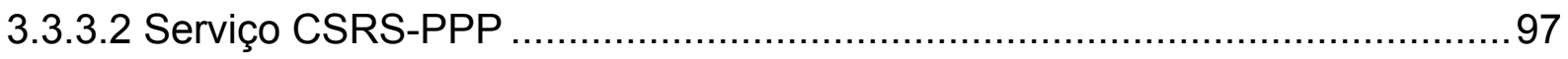

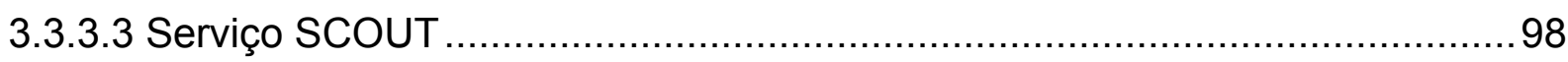

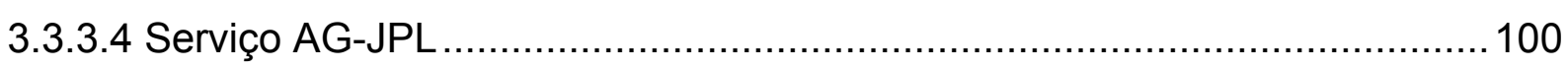

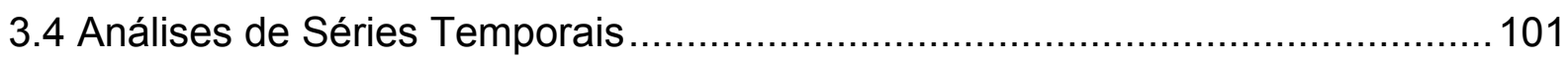

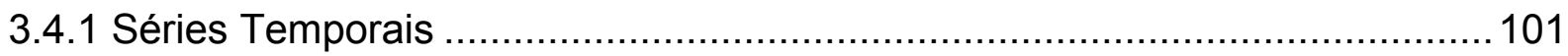


3.4.2 Movimentos Característicos das Séries Temporais .................................. 102

3.4.3 Classificação dos Movimentos das Séries Temporais................................. 102

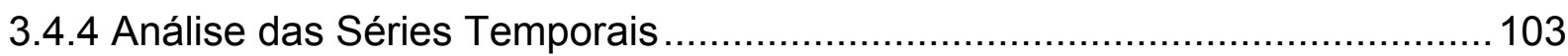

3.4.5 Objetivos da Análise de Séries Temporais ............................................... 104

3.4.6 Médias Móveis (Alisamento de Séries Temporais) …................................. 104

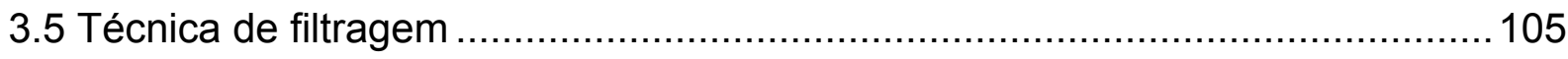

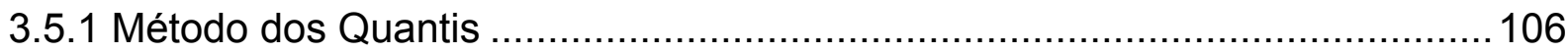

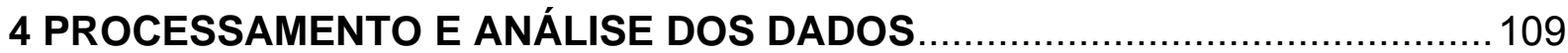

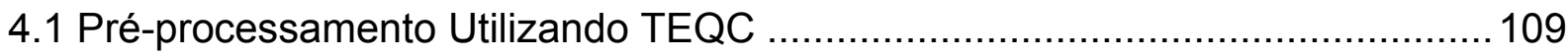

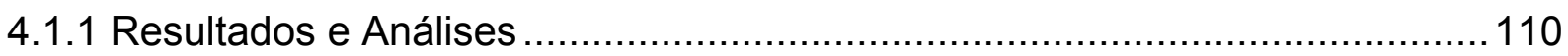

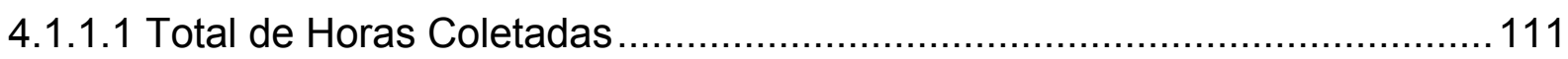

4.1.1.2 Total de Observações Coletadas ........................................................113

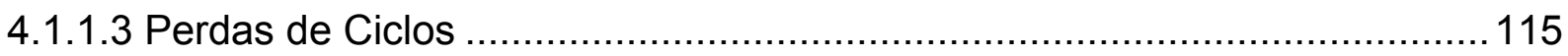

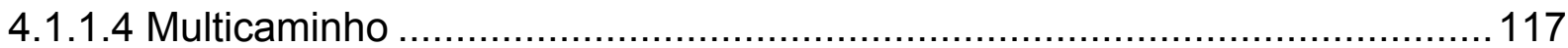

4.2 Processamento Preliminar Utilizando Quatro Diferentes Serviços de

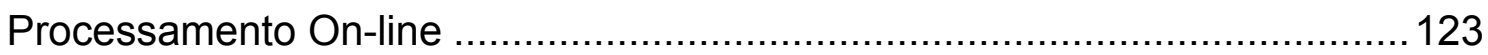

4.2.1 Envio e Processamento dos Arquivos .................................................... 124

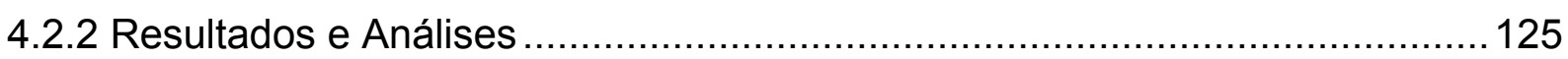

4.2.2.1 Análise das Diferenças da Semana 1 ................................................126

4.2.2.2 Análise das Diferenças da Semana 2 .................................................. 129

4.2.2.3 Análise das Diferenças da Semana 3.................................................. 131

4.3 Processamento Utilizando o Serviço On-line AUSPOS ..................................134

4.3.1 Envio e Processamento dos Arquivos ....................................................... 134

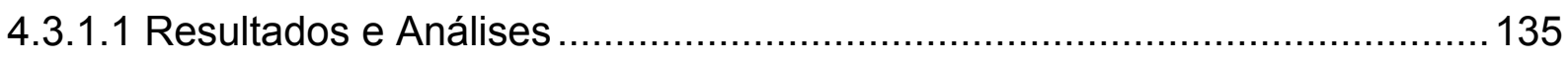

4.4 Processamento Utilizando o Programa Bernese .......................................... 137

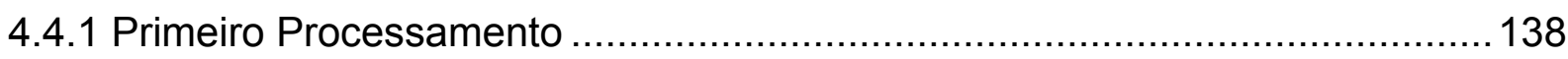

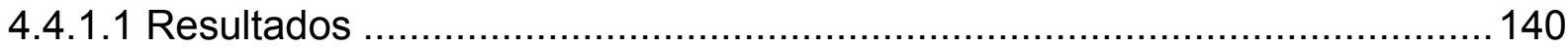

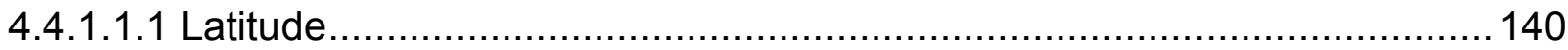

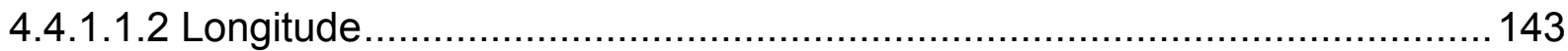

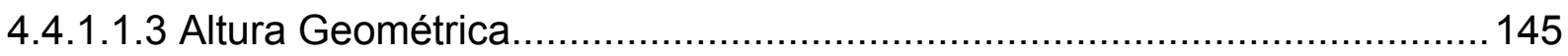

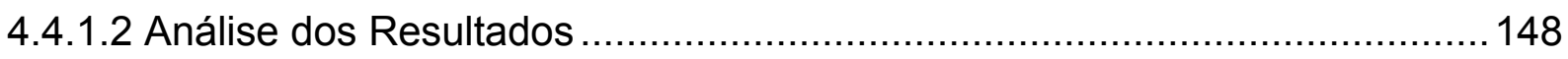

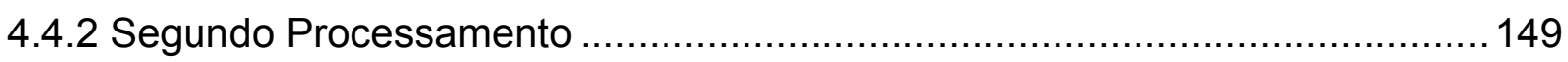

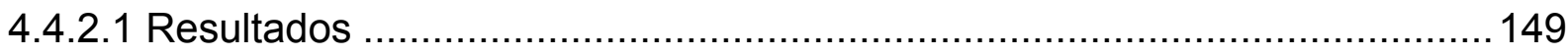

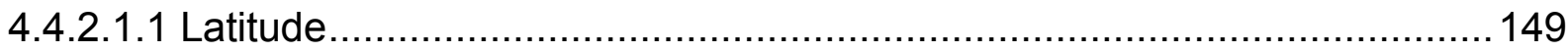


4.4.2.1.2 Longitude

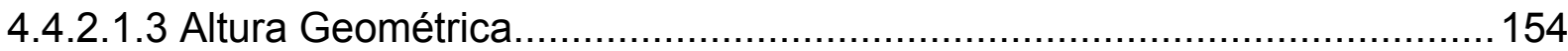

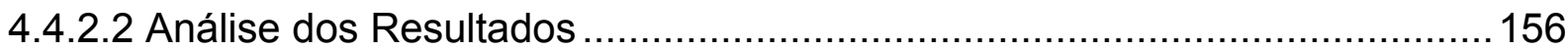

4.5 Comparação entre o processamento utilizando o programa BERNESE e o processamento utilizando o serviço AUSPOS

4.6 Comparação entre o processamento realizado nesta pesquisa e o processamento realizado pelo IBGE.

4.7 Comparação entre o processamento realizado nesta pesquisa e 0 processamento realizado pelo DGFI. 164

5 CONCLUSÕES E RECOMENDAÇÕES 168

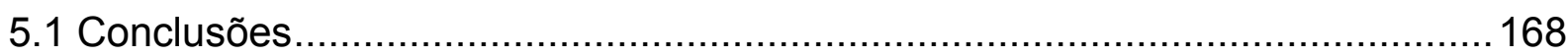

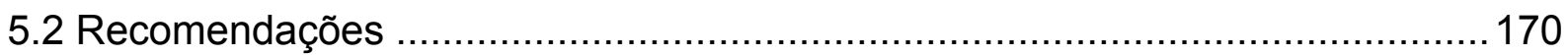

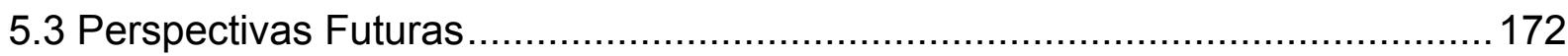

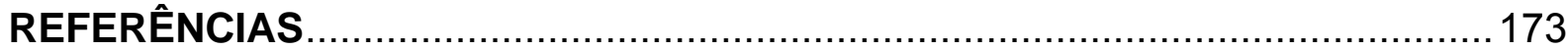

ANEXO A - Arquivo de Saída do Programa TEQC .......................................180 


\section{INTRODUÇÃO}

\subsection{DESCRIÇÃO GERAL}

Nos tempos atuais (2007), quando se pensa em posicionamento com precisão, rapidez, simplicidade operacional e baixo custo, fala-se sempre em utilizar o sistema NAVSTAR-GPS (NAVSTAR - Global Positioning System). O termo NAVSTAR faz referência ao sistema como sendo a "estrela da navegação".

O NAVSTAR GPS, ou simplesmente GPS, é um sistema de radionavegação concebido com a finalidade de ser o principal sistema de navegação das forças militares americanas. Em razão de sua alta exatidão ${ }^{1}$ e do grande desenvolvimento da tecnologia envolvida nos receptores GPS, surgiram usuários dos mais variados segmentos da comunidade civil: navegação, posicionamento geodésico, agricultura, etc, (MONICO, 2000).

O GPS permite que o usuário tenha à sua disposição, no mínimo, quatro satélites para serem observados, estando o observador localizado em qualquer ponto entre a superfície terrestre e a constelação de satélites do sistema. Para os usuários da área de Geodésia, a tecnologia GPS traz um grande benefício em relação aos métodos de levantamento convencionais, ou seja, a não necessidade das estações serem intervisíveis, além de funcionar sob qualquer condição climática.

Sendo as coordenadas dos satélites conhecidas em um sistema de referência adequado, pode-se calcular as coordenadas da antena do usuário no mesmo sistema de referência dos satélites (MONICO, 2000), sendo que, o posicionamento geodésico utilizando o GPS fornece as coordenadas cartesianas $(X, Y, Z)$ de pontos sobre a superfície terrestre, podendo alcançar precisão milimétrica. A partir destas coordenadas, por meio de modelos matemáticos e parâmetros do modelo terrestre envolvido, pode-se transformá-las para coordenadas geodésicas: latitude $(\varphi)$, longitude $(\lambda)$ e altura geométrica ${ }^{2}$ (h) (CASTRO, 2002).

\footnotetext{
${ }^{1}$ A preferência do autor é pela utilização da palavra exatidão ao invés de acurácia.

${ }^{2}$ A preferência do autor é pela utilização do termo altitude quando a mesma é referida ao geóide (altitude ortométrica) e do termo altura quando referida ao elipsóide (altura geométrica), sendo que, ambas têm o mesmo significado lingüístico.
} 
O GPS tem agilizado todo o tipo de posicionamento sobre a superfície terrestre. Unindo o GPS a sistemas de comunicação, têm-se criado novas aplicações de posicionamento, inserindo-se nestas técnicas as redes ativas, chamadas também de Sistemas de Controle Ativo (SCA). Neste caso, usuários que fazem levantamentos GPS relativos não necessitam ocupar as estações de referência, apenas as estações a serem determinadas (FORTES, 1997).

A Fundação Instituto Brasileiro de Geografia e Estatística (IBGE), por intermédio de seu Departamento de Geodésia (DEGED), e em colaboração com o Fundo Nacional de Meio Ambiente (FNMA) e com a Escola Politécnica da USP (EPUSP), iniciou, em 1996, o estabelecimento da rede ativa utilizada atualmente no Brasil, denominada Rede Brasileira de Monitoramento Contínuo do Sistema GPS (RBMC). Suas estações coletam ininterruptamente as observáveis GPS, disponibilizando-as através da internet a quem as queira utilizar.

No Brasil, existem atualmente (fevereiro/2007) 24 estações de rastreio pertencentes à RBMC em funcionamento, dentre a qual a estação NEIA, que a partir de 01/01/2006 passou a integrar a rede. Situada na base "Dr. João Paiva de Carvalho", em Cananéia, a estação faz parte de um projeto conjunto entre o Instituto Oceanográfico da Universidade de São Paulo (IO-USP) e a EP-USP. Os dados da referida estação são o subsídio para o desenvolvimento desta pesquisa.

\subsection{OBJETIVOS}

Os objetivos desta pesquisa consistem na utilização dos dados coletados na estação NEIA para:

- Elaboração de uma metodologia para análise de dados GPS, com o intuito de se demonstrar à qualidade dos mesmos;

- Análise das coordenadas da estação verificando a sua estabilidade e confiabilidade;

- Análise da variação das coordenadas ao longo do tempo, criando um histórico da estação; 
- Servir como modelo metodológico que permita a sua aplicação em outras estações a fim de se obter a qualidade de dados GPS.

\subsection{JUSTIFICATIVA}

Tendo em vista o grande número de usuários que utilizam os dados da estação NEIA para a realização do posicionamento relativo, e que, a estação serve como uma importante referência principalmente para trabalhos realizados no sul do estado de São Paulo (Vale do Ribeira e Litoral Sul) e região norte do estado do Paraná, o controle de qualidade e o histórico do comportamento da estação são importantes para mostrar aos usuários a qualidade dos dados fornecidos, e que, a estação vem ou não sofrendo algum tipo de deslocamento ao longo do tempo, o que, dependendo da aplicação, comprometeria a integridade do trabalho realizado utilizando dados da estação.

\subsection{ESTRUTURA DO TRABALHO}

Este trabalho foi dividido em 5 capítulos, sendo eles: 1) Introdução, 2) Sistemas de Posicionamento Global por Satélite: NAVSTAR-GPS, GLONASS e GALILEO, 3) Materiais e Métodos, 4) Processamento e Análise dos Resultados, e 5) Conclusões e Recomendações.

No primeiro capítulo é realizada uma introdução geral abordando o tema da pesquisa, seus objetivos, sua importância e a estruturação do trabalho. O segundo capítulo descreve os princípios do GPS essenciais para o desenvolvimento desta pesquisa além de informações relativas aos sistemas de posicionamento por satélites GLONASS e GALILEO. O capítulo três descreve os materiais e os métodos utilizados no desenvolvimento da pesquisa. O quarto capítulo apresenta o detalhamento dos processamentos realizados para o controle de qualidade e para o cálculo das coordenadas da estação, além das análises dos resultados obtidos após 
os processamentos. O capítulo cinco contém as considerações finais, conclusões e recomendações para futuros trabalhos. 


\section{SISTEMAS DE POSICIONAMENTO GLOBAL POR SATÉLITE}

Nos últimos 20 anos, o termo GNSS (Global Navigation Satellite System) foi praticamente sinônimo de NAVSTAR-GPS. Logicamente que, o GPS não era o único sistema GNSS disponível, pois, o sistema russo GLONASS (GLObal'naya NAvigatsionnay Sputnikovaya Sistema) também já era operacional durante grande parte deste período. Entretanto, o sistema GLONASS foi tendo sua constelação drasticamente reduzida devido à falta de manutenção, fazendo com que o sistema já não oferecesse mais confiabilidade (AKOS, 2006).

Mas com a grande importância que os sistemas de navegação por satélite passaram a ter, decidiu-se no final dos anos 1990 e início dos anos 2000 pela manutenção e modernização do GLONASS, além da modernização e a integração de novos sinais do GPS sendo que, a mais significativa mudança foi a criação de um terceiro sistema GNSS, sediado na Europa, denominado GALILEO. Os novos sinais, e a integração dos três sistemas permitirão que o GNSS seja utilizado com desempenho melhor do que em sua primeira geração (AKOS, 2006).

Incluem-se na denominação GNSS além dos sistemas de posicionamento global GPS, GLONASS e GALILEO, os sistemas geoestacionários lançados por alguns países no intuito de melhorar, para uma dada região, a precisão dos três sistemas principais como, por exemplo, o sistema europeu EGNOS (European Geostationary Navigation Overlay Service) e o sistema norte-americano WAAS (Wide-Area Augmentation System).

A seguir, serão descritos os três sistemas de posicionamento global. Será dado maior destaque ao GPS, pois, neste trabalho foram utilizados apenas dados deste sistema. Isto se deve ao fato do receptor utilizado não ter a capacidade de receber sinais GLONASS e o sistema GALILEO estar ainda em fase de implantação. O GLONASS, a exemplo do GPS, é um sistema desenvolvido exclusivamente para uso militar, mas acabou sendo envolvido gradualmente às aplicações civis, enquanto que, o GALILEO, está sendo desenvolvido por organismos civis e visa ser um serviço tanto para uso civil quanto militar. 


\subsection{NAVSTAR-GPS}

Criado pelo U.S. Department of Defense (DoD), o sistema NAVSTAR - GPS foi construído para ser o sistema de navegação mais preciso para fins militares, com o objetivo de substituir o sistema de navegação Transit.

O sistema Transit, oficialmente chamado por Navy Navigation Satellite System (NNSS), foi planejado nos anos 1950 e desenvolvido nos anos 1960. Este foi o antecessor do sistema GPS e atualmente não conta com nenhum satélite em órbita, pois, todos foram desativados em 1996 após quase 33 anos de serviço. O sistema Transit foi desenvolvido devido a necessidade de fornecer dados para a navegação dos submarinos nucleares da classe Polaris. Os submarinos posicionavam-se utilizando uma antena que era colocada dentro de um cilindro de fibra de vidro sobre um periscópio móvel, sendo necessário que a mesma fosse exposta acima do nível da água para receber os sinais dos satélites (RUEGER, 1998).

Para realizar o posicionamento, o NNSS utilizava o princípio do efeito Doppler através das ondas eletromagnéticas, mas que, devido a pequena quantidade de satélites, apenas 6 , e suas órbitas serem muito baixas (1100 km), não se tinha como obter posições com muita freqüência e com uma alta precisão (GEMAEL, 2004). Para se obter uma posição com uma incerteza de três a dez metros era necessário ficar de dois a três dias estacionado sobre o mesmo ponto.

O satélite Transit permanecia acima do horizonte por no máximo 18 minutos, com observações intervaladas de 4,6 segundos. Como são quatro as incógnitas a serem determinadas (três coordenadas do centro de fase da antena e a deriva do relógio), a solução por mínimos quadrados, praticamente em tempo real, satisfaz a navegação, mas não a Geodésia. Em termos geodésicos a solução mais usual era utilizar o método de multipassagem, que consistia em acumular várias observações durante um período de tempo, como por exemplo, dois dias. O ajustamento, neste caso, era feito seqüencialmente, e o cálculo das coordenadas levava em conta a contribuição das passagens anteriores (GEMAEL, 2004).

O sistema de satélites para posicionamento era de responsabilidade do Joint Program Office (JPO), localizado na Air Force Base (AFB) em Los Angeles. Em 1973, o JPO, foi orientado pelo DoD a fim de estabelecer, desenvolver e testar um 
novo sistema de posicionamento global. Deste projeto nasceu o NAVSTAR-GPS (HOFMANN-WELLENHOF et al., 1997).

O GPS tornou possível o posicionamento tridimensional em tempo real, o que ainda não era possível com o sistema Transit. O sistema GPS permitiu ainda, a obtenção de informações precisas de tempo, e pode ser utilizado em quaisquer condições climáticas além de não necessitar de intervisibilidade entre os pontos.

Devido à sua alta exatidão e ao grande desenvolvimento de sua tecnologia, passou a ser utilizado em larga escala nos mais diferentes segmentos da comunidade civil, como, por exemplo: navegação, levantamentos geodésicos, meteorologia, aeronomia, controle de frotas, agricultura de precisão, monitorar o movimento da crosta, dentre outros.

A fim de conjugar os usos civil e militar do Sistema de Posicionamento Global, foram criadas soluções para impossibilitar a navegação precisa de mísseis inimigos (GEMAEL, 2004):

1) Selective Availability (SA) - disponibilidade seletiva: deterioração intencional do potencial de posicionamento do código $\mathrm{C} / \mathrm{A}$, realizada pela degradação intencional do relógio (técnica dither: $\delta$ ) e/ou das efemérides (técnica épsilon: $\xi)$. A SA encontra-se desativada desde maio de 2000, quando o então presidente dos Estados Unidos da América Bill Clinton, decidiu suspender a SA, em razão do desenvolvimento da técnica para aplicá-la regionalmente quando necessário, recebendo o nome de Selective Denial - SD (Proibição Seletiva);

2) Anti-spoofing (AS) - anti-burla: criptografia do código $P$ para o código $Y$ e;

3) Limites de altitude $(<18000 \mathrm{~m})$ e de velocidade $(<515 \mathrm{~m} / \mathrm{s})$ para 0 funcionamento de receptores.

Estas ressalvas fazem com que mísseis só possam ser navegados por receptores fabricados com a autorização do DoD.

Em razão destes cuidados, dois serviços passaram a existir (GEMAEL, 2004):

- SPS - Standard Positioning System (Sistema de Posicionamento Padrão): serviço de posicionamento e tempo padrão disponibilizado a todos os usuários do globo, sem cobrança de taxa. Com ele, atualmente, pode obter-se uma exatidão posicional da ordem de 15 a 25 m com receptores de navegação e precisão melhor que $10 \mathrm{~m}$ com receptores 
geodésicos em 95\% do tempo (DIVIS, 2000 apud FREIBERGER Jr., 2002);

- PPS - Precise Positioning Service (Serviço de Posicionamento Preciso): utiliza desde janeiro/1994 o AS para criptografar o código $P$, tornando-se um serviço restrito a uso militar e a usuários autorizados (GEMAEL, 2004). Proporciona exatidão de 10 e $20 \mathrm{~m}$ respectivamente para a componente horizontal e vertical. O DoD não tem interesse em disponibilizá-lo abertamente a todos os usuários do GPS, devido a questões de segurança (MONICO, 2000).

O Sistema de Posicionamento Global é estruturado em três setores fundamentais dependentes entre si: o segmento espacial, o segmento de controle e o segmento dos usuários (LEICK, 1995).

\subsubsection{SEGMENTO ESPACIAL}

O segmento espacial tem como função principal gerar e transmitir os sinais do Sistema de Posicionamento Global.

Consiste atualmente (dezembro/2006) de 30 satélites distribuídos em seis planos orbitais (nomeados de A a F), inclinados $55^{\circ}$ em relação ao plano do equador, estando a uma altitude aproximada de $20.200 \mathrm{~km}$ acima da superfície terrestre, perfazendo um período de revolução de aproximadamente 12 horas siderais (aproximadamente 11 horas e 58 minutos no horário legal). Informações referentes à operacionalidade dos satélites podem ser obtidas no endereço http://www.navcen.uscg.gov/ (visitado em junho de 2006), do Navigation Center (NAVCEN) da Guarda Costeira Norte-Americana.

Os satélites têm várias maneiras de serem identificados, podendo ser através: do Space Vehicle Number (SVN) baseado na seqüência de lançamento dos mesmos, do número de sua posição orbital, do número catalogado pela National Aeronautics and Space Administration (NASA) ou pelo seu Pseudo Randon Noise PRN (ver seção 2.1.4), que é um identificador que o satélite recebe assim que entra 
em sua órbita, sendo este último o mais utilizado para identificar o satélite (HOFMANN-WELLENHOF et al., 1997).

No segmento espacial existem 5 blocos de satélites classificados conforme sua construção, descritos a seguir (UNITED STATES NAVAL OBSERVATORY, 2006):

- Satélites do Bloco I: nesta etapa foram lançados os SVN de 1 a 11, entre os anos de 1978 a 1985. Possuíam 3 relógios atômicos, sendo 1 de césio e 2 de rubídio, e tinham expectativa de vida útil por volta de 5 anos, mas em sua maioria seu tempo de vida foi maior. Não existe mais nenhum satélite deste bloco em operação, sendo que o último satélite operacional (SVN 10) foi desativado em 1995. A inclinação da órbita dos satélites, deste bloco, era de $63^{\circ}$ em relação ao plano do equador;

- Satélites do Bloco II: são os SVN de 12 a 21, sendo que, o SVN 12 nunca foi lançado, pois se tratava apenas de um protótipo. Foram projetados de maneira a funcionar corretamente por até 14 dias sem contato com o Segmento de Controle, sendo lançados entre fevereiro/1989 e outubro/1990. A partir deste bloco passou-se a utilizar a inclinação de $55^{\circ}$ em relação ao plano do equador;

- Satélites do Bloco IIA (Advanced - avançado): os SVN de 22 a 40, foram projetados para serem operantes sem contato com o Segmento de Controle por até 180 dias. A única ressalva é que durante esses 180 dias de autonomia haveria perda da exatidão pela não correção das mensagens de navegação. Os satélites dos blocos II e IIA possuem 4 relógios atômicos ( 2 de césio e 2 de rubídio), têm vida útil estimada de 7,3 anos além de terem a capacidade de ativação da SA e do AS, não disponibilizados no Bloco I;

- Satélites do Bloco IIR (Replenishment - reposição): são os SVN de 41 a 62, projetados para trabalhar até 180 dias operando no modo de navegação autônoma (AUTONAV - AUTOnomously NAVigate). Sua exatidão é mantida usando a técnica de medição de distâncias e comunicação entre os satélites do Bloco IIR. Essa capacidade de medir as distâncias entre si é usada para estimar e atualizar os parâmetros nas mensagens de navegação, calculando suas próprias efemérides. Foram projetados com expectativa de vida de 7,8 anos, possuem 3 relógios 
atômicos de rubídio e também possuem a capacidade da SA e do AS. Seus lançamentos ocorreram entre os anos de 1997 a 2004, e atualmente existem 12 deles em órbita;

- Satélites do Bloco IIR-M (Modernizado): o SVN 53 lançado em 26 de setembro de 2005 é o primeiro satélite GPS modernizado que possibilita a transmissão de dois novos sinais militares e um segundo sinal civil (L2C). Além deste, mais dois satélites modernizados do GPS foram lançados sendo, um em 25 de setembro de 2006 (SVN 52) e outro em 17 de novembro de 2006, o SVN 58.

Mais informações sobre os satélites e atualizações da constelação GPS podem ser obtidas através do endereço http://tycho.usno.navy.mil/gpscurr.html (visitado em janeiro de 2007).

\subsubsection{SEgmento de CONTROLE}

O segmento de controle do GPS (OCS - Operational Control Segment) é responsável pela operação do Sistema de Posicionamento Global. Consiste atualmente de 11 estações monitoras e uma Estação Principal de Controle (MCS Master Control Station), localizada na Base da Força Aérea Americana em Colorado Springs (FEDERAL AVIATION ADMINISTRATION, 2006).

A MCS utiliza as informações coletadas pelas estações monitoras para prever o comportamento da órbita de cada satélite e a deriva em seus relógios. Depois de realizados os cáculos, os dados previstos são transmitidos aos satélites, que por sua vez retransmitem estas informações para os usuários. O segmento de controle assegura também que as órbitas dos satélites e a deriva dos relógios permaneçam dentro dos limites aceitáveis (FEDERAL AVIATION ADMINISTRATION, 2006), estes limites de incerteza são de até $160 \mathrm{~cm}$ para a órbita e $7 \mathrm{~ns}$ para os relógios (INTERNATIONAL GNSS SERVICE, 2006).

Originalmente, o segmento de controle do GPS era composto por uma rede de 5 estações terrestre, situadas em: Colorado Springs, no Hawaii, nas Ilhas Ascension (Oceano Atlântico), no Atol Diego Garcia (Oceano Indico) e nas Ilhas Kwajalein 
(Oceano Pacífico Sul). Em 1997, a FAA (Federal Aviation Administration), a National Geospatial-Intelligency Agency (NGA) e outros órgãos iniciaram processos para a melhoria da exatidão, em um projeto chamado de All (Accuracy Improvement Initiative), que, evoluiu para o L-All (Legacy Accuracy Improvement Initiative). De acordo com o L-All estava prevista inicialmente a inclusão de seis e eventualmente onze estações monitoras da NGA ao segmento de controle do GPS, bem como a melhoria dos modelos e processos utilizados na determinação/predição das órbitas. Os principais objetivos desta iniciativa foram: possibilitar o rastreio de todos os satélites GPS a qualquer instante, melhorar em 10\% a exatidão das observações e em $50 \%$ os resultados da previsão das órbitas (CREEL et al, 2006). Destes objetivos, o primeiro foi integralmente atingido; o segundo também foi atingido, mas necessita de uma análise adicional; e o terceiro ficou próximo do valor previamente especificado, atingindo $44 \%$ de melhoria nos resultados de previsão das órbitas.

A Figura 1 apresenta a disposição atual das estações cujos dados são utilizados pelo segmento de controle do GPS.

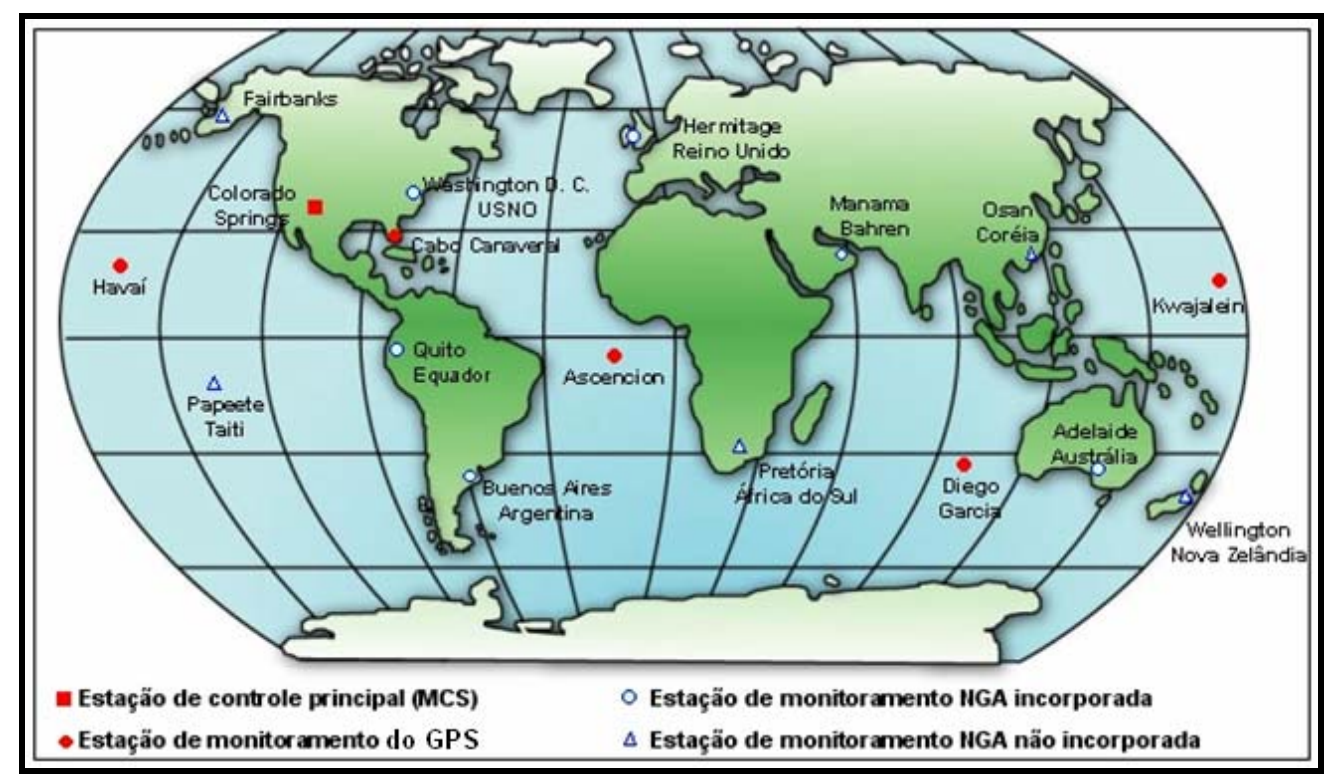

Figura 1: Estações do segmento de controle do GPS Fonte: adaptado de CREEL et al., 2006

Resumidamente, pode-se dizer que as principais tarefas do segmento de controle são (MONICO, 2000):

- Monitorar e controlar ininterruptamente o sistema de satélites;

- Determinar o sistema de tempo GPS; 
- Prever as efemérides e calcular as correções dos relógios dos satélites e;

- Atualizar periodicamente as mensagens de navegação de cada satélite.

\subsubsection{SEGMENTO DE USUÁRIOS}

É constituído por tudo que se relaciona com a comunidade usuária do sistema, como receptores e programas, ou seja, está associado às aplicações do sistema GPS, e está dividido em duas classes: civil e militar (MONICO, 2000).

Nas atividades militares o GPS foi integrado em bombardeiros, em tanques de guerra, em helicópteros, em navios, em submarinos, nos equipamentos dos soldados e visam posicionamento para estratégias de combate, definição de alvos e para a navegação de mísseis. Já a comunidade civil, tem em seu segmento uma grande diversidade de aplicações, sendo utilizado para levantamentos geodésicos, implantação/densificação de redes geodésicas, controle de estruturas e deformações, na agricultura de precisão, na aeronomia, na meteorologia, além de outras infindáveis aplicações, pois o GPS tem a capacidade de servir a um número ilimitado de usuários ao mesmo tempo.

\subsubsection{CARACTERÍSTICAS DOS SINAIS GPS}

Todos os satélites da constelação GPS transmitem duas portadoras (L1 e L2), que tem suas freqüências geradas a partir da freqüência fundamental $\left(f_{0}\right)$ de 10,23 $\mathrm{MHz}$, que ao ser multiplicada por 154 e 120 geram as seguintes freqüências (Banda $L)$ e respectivos comprimentos de onda ( $\lambda$ ), Monico (2000):

$$
\mathrm{L} 1=154 . \mathrm{f}_{0}=1575,42 \mathrm{MHz} \text { e } \lambda \cong 19,0 \mathrm{~cm}
$$


O código PRN é modulado sobre as duas portadoras, sendo composto por uma seqüência binária (0 e 1 ou, +1 e -1) que apresenta característica aleatória. Como essa seqüência é gerada por um algoritmo, o PRN pode ser univocamente identificado. Na portadora L1, são modulados os códigos Coarse Aquisition (C/A) e Precise or Protected $(P)$, e a mensagem de navegação, enquanto que na portadora L2 são modulados os códigos L2C (Civil) e P (Figura 2). Informações sobre a nova portadora L5 podem ser vistas no item (2.1.11).

O código C/A apresenta comprimento de onda de aproximadamente $300 \mathrm{~m}$, possui freqüência de $1,023 \mathrm{MHz}$ e período de repetição de $1 \mathrm{~ms}$. Cada satélite transmite um código C/A diferente. Para evitar que um receptor de sinais GPS tenha dificuldades em distinguir entre os códigos possíveis, os mesmos possuem como característica a baixa correlação entre si, que possibilita a distinção dos sinais recebidos de vários satélites simultaneamente (MONICO, 2000).

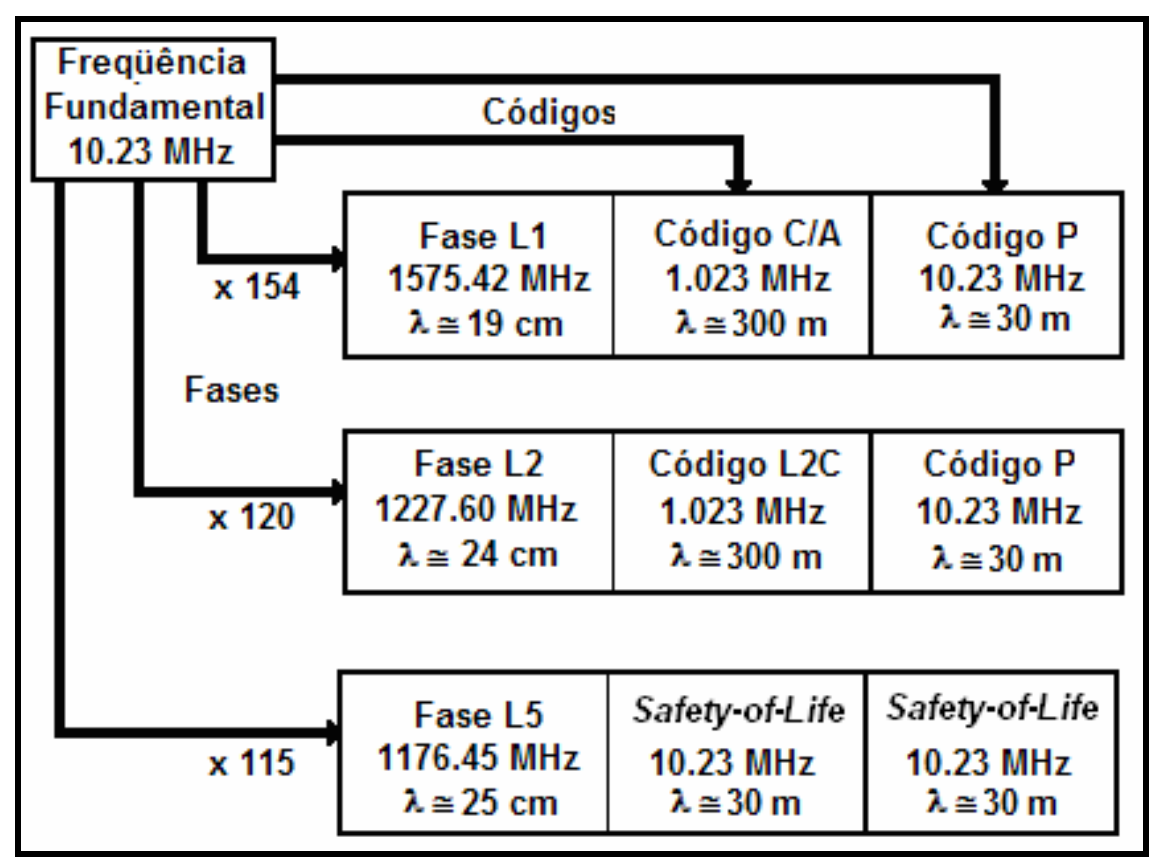

Figura 2: Estrutura dos sinais GPS

Fonte: Adaptado de Bruyninx, 2002

O código $P$, de uso exclusivo dos militares americanos e dos usuários autorizados, apresenta comprimento de onda de aproximadamente $30 \mathrm{~m}$, possui freqüência de $10,23 \mathrm{MHz}$ e intervalo de repetição de 266 dias. O seu comprimento 
de onda, 10 vezes menor do que o do código C/A, resulta em medidas mais precisas. Os códigos são arranjados de forma a produzir 37 seqüências, cada uma com duração de 7 dias, perfazendo assim 37 PRNs. A cada satélite é atribuído um PRN modulado em L1 e L2, dessa forma, todos os satélites transmitem na mesma freqüência, mas podem ser identificados pelo código exclusivo de cada satélite através da técnica Code Division Multiple Access (CDMA), sendo válido tanto para o código C/A como para o código P. (MONICO, 2000).

A mensagem de navegação contém informações sobre: parâmetros de correção dos relógios dos satélites, idade dos dados, número da semana GPS, parâmetros orbitais, satélites com problemas, informação do AS, modelos da ionosfera, diferença entre o tempo GPS e o tempo UTC, além de, uma área reservada a mensagens especiais. Ela é transmitida sob a forma de um quadro de dados, dividido em 5 subquadros, que comporta até 1500 bits de informação. Cada subquadro contém 10 palavras (30 bits), e é transmitido em 6 segundos. Os subquadros 1, 2 e 3 possuem uma só página, enquanto que, os subquadros 4 e 5 , possuem 25 páginas cada um, portanto, são necessários 25 ciclos para transmitir os 25 quadros com a mensagem completa, sendo o tempo total de aquisição da mensagem de navegação de 12,5 minutos (GEMAEL, 2004).

O princípio básico do posicionamento pelo Sistema de Posicionamento Global consiste na medida de distâncias (pseudodistâncias) entre o usuário e no mínimo quatro satélites. Para se obter a posição do usuário, apenas três distâncias não pertencentes ao mesmo plano seriam suficientes. A quarta medida é necessária em razão do não-sincronismo entre os relógios dos satélites e do receptor (MONICO, 2000).

\subsubsection{AS OBSERVÁVEIS GPS}

As observáveis básicas do Sistema de Posicionamento Global permitem determinar a posição, a velocidade e o tempo. Podem ser identificadas como (MONICO, 2000): 
- Pseudodistância a partir do código, que atualmente é utilizada para levantamentos em que não se deseja alcançar alta precisão, com erro acima do metro, e;

- Fase da onda portadora ou diferença da fase de onda portadora, utilizada em levantamentos em que se necessite de alta precisão, que pode variar do milímetro a poucos decímetros.

\subsubsection{PSEUDODISTÂNCIA}

A pseudodistância é a distância medida entre o centro de fase da antena do satélite e o centro de fase da antena do receptor (LEICK, 1995). Assim que o código chega ao receptor, ele gera uma réplica idêntica ao sinal gerado pelo satélite (MONICO, 2000).

A distância satélite-receptor é obtida pela multiplicação do tempo que a onda eletromagnética gasta para percorrê-la, e pela velocidade da luz no vácuo (GEMAEL, 2004). O tempo que a onda leva para percorrer a distância satélitereceptor é determinado através da correlação entre o código gerado pelo satélite no instante de transmissão, e sua réplica gerada no receptor para o instante de recepção.

Na literatura sobre o Sistema de Posicionamento Global, essa observável é denominada pseudodistância, ao invés da distância, em razão do não sincronismo entre os relógios (osciladores) responsáveis pela geração do código no satélite e sua réplica no receptor (MONICO, 2000).

O não sincronismo entre os relógios se deve ao fato dos relógios dos satélites GPS, que possuem padrões atômicos (césio e rubídio) de alta precisão, serem muito mais estáveis que os relógios dos receptores, que são de quartzo.

A equação da pseudodistância $\left(\mathrm{PD}_{\mathrm{r}}^{\mathrm{s}}\right)$ entre o satélite $(\mathrm{s})$ e o receptor $(r)$ é definida como (MONICO, 2000): 


$$
\mathrm{PD}_{\mathrm{r}}^{\mathrm{s}}=\rho_{\mathrm{r}}^{\mathrm{s}}+\mathrm{c} \cdot\left[\mathrm{dt}_{\mathrm{r}}-\mathrm{dt}^{\mathrm{s}}\right]+\mathrm{I}_{\mathrm{r}}^{\mathrm{s}}+\mathrm{T}_{\mathrm{r}}^{\mathrm{s}}+\mathrm{dm}_{\mathrm{r}}^{\mathrm{s}}+\varepsilon_{\mathrm{PDr}}^{\mathrm{s}}
$$

sendo:

$\rho_{\mathrm{r}}^{\mathrm{s}}$ - distância geométrica entre o receptor (r) e o satélite (s);

c - velocidade da luz no vácuo;

$\mathrm{dt}_{\mathrm{r}}$ - erro do relógio do receptor em relação ao tempo GPS no instante tr;

$\mathrm{dt}^{\mathrm{s}}$ - erro do relógio do satélite em relação ao tempo GPS no instante ts;

$\mathrm{I}_{\mathrm{r}}^{\mathrm{s}}$ - efeito sistemático devido à refração ionosférica;

$\mathrm{T}_{\mathrm{r}}^{\mathrm{s}}$ - efeito sistemático devido à refração troposférica;

$\mathrm{dm}_{\mathrm{r}}^{\mathrm{s}}$ - erro devido ao multicaminho;

$\varepsilon_{\mathrm{PDr}}^{\mathrm{s}}-$ representa os erros aleatórios e outros erros sistemáticos.

Na distância geométrica $\left(\rho_{\mathrm{r}}^{\mathrm{s}}\right)$ estão implícitas as coordenadas do satélite e do receptor, como pode ser visto na equação:

$$
\rho_{\mathrm{r}}^{\mathrm{s}}=\sqrt{\left(\mathrm{X}^{\mathrm{s}}-\mathrm{X}_{\mathrm{r}}\right)^{2}+\left(\mathrm{Y}^{\mathrm{s}}-\mathrm{Y}_{\mathrm{r}}\right)^{2}+\left(\mathrm{Z}^{\mathrm{s}}-\mathrm{Z}_{\mathrm{r}}\right)^{2}}
$$

onde:

$\mathrm{X}^{\mathrm{s}}, \mathrm{Y}^{\mathrm{s}}, \mathrm{Z}^{\mathrm{s}}$ - coordenadas cartesianas do satélite e;

$\mathrm{X}_{\mathrm{r}}, \mathrm{Y}_{\mathrm{r}}, \mathrm{Z}_{\mathrm{r}}$ - coordenadas cartesianas da antena do receptor.

\subsubsection{FASE DA ONDA PORTADORA}

Muito mais precisa que a pseudodistância, a fase da onda portadora é uma observável fundamental para várias atividades geodésicas. A fase da onda portadora observada $\left(\phi_{\mathrm{r}}^{\mathrm{s}}\right)$, em unidades de ciclos, é dada por (MONICO, 2000): 


$$
\phi_{\mathrm{r}}^{\mathrm{s}}(\mathrm{t})=\phi_{\mathrm{r}}(\mathrm{t})-\phi^{\mathrm{s}}(\mathrm{t})+\mathrm{N}_{\mathrm{r}}^{\mathrm{s}}+\varepsilon_{\phi_{\mathrm{r}}}^{\mathrm{s}}
$$

onde:

$\mathrm{t}$ - instante de recepção do sinal na estação r;

$\phi^{\mathrm{s}}(\mathrm{t})$ - fase da portadora gerada no satélite (s) e recebida na estação ( $r$ ) no instante de recepção;

$\phi_{\mathrm{r}}(\mathrm{t})$ - fase gerada no receptor no instante de recepção;

$\mathrm{N}_{\mathrm{r}}^{\mathrm{s}}$ - ambigüidade da fase e;

$\varepsilon_{\phi_{\mathrm{r}}}^{\mathrm{s}}$ - resíduos não modelados na fase da onda portadora.

A medida de fase $\phi$ de uma onda qualquer, com freqüência $\mathrm{f}$, pode ser representada por (MONICO, 2000):

$$
\phi(t)=\int_{t_{0}}^{t} f d \tau=-\phi\left(t_{0}\right)+f .(t+d t)
$$

sendo $\phi\left(\mathrm{t}_{0}\right)$ a fase numa época de referência $\mathrm{t}_{0} \mathrm{e} d \mathrm{~d}$ o erro do relógio.

A fase da portadora $\phi^{\mathrm{s}}(\mathrm{t})$, gerada no satélite $\mathrm{s}$ e recebida na estação $\mathrm{r}$, pode ser relacionada com a fase gerada no instante de transmissão $t^{t}$ (MONICO, 2000):

$$
\mathrm{t}^{\mathrm{t}}=\mathrm{t}-\tau
$$

onde $\tau$ é o intervalo de tempo de propagação do sinal, o qual é função da distância geométrica entre o satélite e o receptor e dos, efeitos de troposfera e ionosfera. Esta relação se dá pela lei de conservação dos ciclos, ou seja, que a fase recebida no receptor é igual à fase transmitida pelo satélite $\phi^{\mathrm{s}}(\mathrm{t})$, chegando-se a seguinte expressão (MONICO, 2000):

$$
\phi^{\mathrm{s}}(\mathrm{t})=\phi_{\mathrm{t}}^{\mathrm{s}}(\mathrm{t}-\tau) \cong \phi_{\mathrm{t}}^{\mathrm{s}}-\mathrm{f} \tau
$$


sendo obtida através do desenvolvimento em série $\left(\phi_{\mathrm{t}}^{\mathrm{s}}(\mathrm{t}-\tau)=\phi_{\mathrm{t}}^{\mathrm{s}}(\mathrm{t})-\frac{\partial \phi_{\mathrm{t}}^{\mathrm{s}}}{\mathrm{dt}} \tau-\ldots\right)$, desprezando-se os termos de ordem superior à primeira. A freqüência $\mathrm{f}$ é nominalmente constante, mas pode variar em razão da instabilidade do oscilador e da degradação ocasionada pela SA, hoje não mais, devido ao desligamento da mesma. Utilizando desenvolvimento similar ao da expressão (2.6), obtém-se (MONICO, 2000):

$$
\phi^{\mathrm{s}}(\mathrm{t})=-\phi_{\mathrm{t}}^{\mathrm{s}}\left(\mathrm{t}_{0}\right)+\mathrm{f} \cdot\left[\mathrm{t}+\mathrm{dt}^{\mathrm{s}}\left(\mathrm{t}^{\mathrm{t}}\right)\right]-\mathrm{f} \tau
$$

Analogamente, pode-se expandir a expressão representando a fase gerada no receptor, ou seja (MONICO, 2000):

$$
\phi_{\mathrm{r}}(\mathrm{t})=-\phi_{\mathrm{r}}\left(\mathrm{t}_{0}\right)+\mathrm{f} \cdot\left[\mathrm{t}+\mathrm{dt}_{\mathrm{r}}(\mathrm{t})\right]
$$

Substituindo-se as equações (2.9) e (2.10) na equação (2.5), obtém-se (MONICO, 2000):

$$
\phi_{\mathrm{r}}^{\mathrm{s}}(\mathrm{t})=\mathrm{f} \cdot \tau+\mathrm{f} \cdot\left[\left(\mathrm{dt}_{\mathrm{r}}(\mathrm{t})-\mathrm{dt}^{\mathrm{s}}\left(\mathrm{t}^{\mathrm{t}}\right)\right]+\left[\phi_{\mathrm{t}}^{\mathrm{s}}\left(\mathrm{t}_{0}\right)-\phi_{\mathrm{r}}\left(\mathrm{t}_{0}\right)\right]+\mathrm{N}_{\mathrm{r}}^{\mathrm{s}}+\varepsilon_{\phi_{\mathrm{r}}}^{\mathrm{s}}\right.
$$

O intervalo de tempo de propagação do sinal em (2.11), é descrito em função da parte geométrica $\left(\rho_{\mathrm{r}}^{\mathrm{s}} / \mathrm{c}\right)$, e inclui ainda os efeitos da refração ionosférica $\left(\mathrm{I}_{\mathrm{r}}^{\mathrm{s}} / \mathrm{c}\right)$, da refração troposférica $\left(\mathrm{T}_{\mathrm{r}}^{\mathrm{s}} / \mathrm{c}\right)$ e do multicaminho $(\mathrm{dm} / \mathrm{c})$. Sendo assim, a expressão da fase da onda portadora, pode ser escrita como (MONICO, 2000):

$$
\phi_{\mathrm{r}}^{\mathrm{s}}(\mathrm{t})=\mathrm{f}\left(\frac{\rho_{\mathrm{r}}^{\mathrm{s}}-\mathrm{I}_{\mathrm{r}}^{\mathrm{s}}+\mathrm{T}_{\mathrm{r}}^{\mathrm{s}}+\mathrm{dm}}{\mathrm{c}}\right)+\mathrm{f} \cdot\left[\mathrm{dt}_{\mathrm{r}}-\mathrm{dt}^{\mathrm{s}}\right]+\left[\phi^{\mathrm{s}}\left(\mathrm{t}_{0}\right)-\phi_{\mathrm{r}}\left(\mathrm{t}_{0}\right)\right]+\mathrm{N}_{\mathrm{r}}^{\mathrm{s}}+\varepsilon_{\phi_{\mathrm{r}}}^{\mathrm{s}}
$$

sendo:

f - é a freqüência transmitida pelo satélite; 
c - é a velocidade da luz no vácuo;

$\rho_{\mathrm{r}}^{\mathrm{s}}$ - representa a distância geométrica entre o receptor (r) e o satélite (s);

$\mathrm{dt}_{\mathrm{r}}$ - erro do relógio do receptor em relação ao tempo GPS no instante tr;

$\mathrm{dt}^{\mathrm{s}}$ - erro do relógio do satélite em relação ao tempo GPS no instante ts;

$\mathrm{I}_{\mathrm{r}}^{\mathrm{s}}$ - efeito sistemático devido a refração ionosférica;

$\mathrm{T}_{\mathrm{r}}^{\mathrm{s}}$ - efeito sistemático devido a refração troposférica;

$\mathrm{dm}$ - erro devido ao multicaminho;

$\phi^{\mathrm{s}}$ - fase da portadora gerada no satélite (s) e recebida na estação (r) no instante de recepção;

$\phi_{\mathrm{r}}$ - fase gerada no receptor no instante de recepção;

$\mathrm{t}_{0}$ - época de referência;

$\mathrm{N}_{\mathrm{r}}^{\mathrm{s}}$ - ambigüidade da fase e;

$\varepsilon_{\phi_{\mathrm{r}}}^{\mathrm{s}}$ - resíduos não modelados na fase da onda portadora.

\subsubsection{EFEMÉRIDES}

Para a realização do posicionamento utilizando o Sistema de Posicionamento Global, é necessário que se conheça as coordenadas dos satélites, pois as mesmas servirão de referência para a determinação das coordenadas dos pontos de interesse.

As posições dos satélites são determinadas a partir de informações orbitais inseridas nas mensagens de navegação, que são transmitidas pelos satélites, e são conhecidas por efemérides transmitidas. Também se pode obter $\mathrm{o}$ arquivo de efemérides através da internet, onde as mesmas já estão corrigidas dos efeitos que afetam a órbita do satélite, e são denominadas "efemérides precisas" (HOFMANNWELLNHOF et al., 1997).

A seguir, os dois tipos de efemérides são descritos com mais detalhes. 
As efemérides transmitidas são previstas para permitir seu uso imediato, e por isso, possuem erros superiores aos das efemérides precisas (GEMAEL, 2004).

Duas etapas são necessárias para a produção das efemérides transmitidas (MARQUES; SANTANA; MONICO, 2003):

- Primeiramente, são produzidas efemérides de referência para um determinado período, baseado em um modelo que considera as forças que atuam sobre o satélite, como: as forças de atração da Terra, do Sol e da Lua, e a pressão da radiação solar que incide no satélite;

- Depois, as diferenças entre as observações coletadas nas estações monitoras e as calculadas utilizando as efemérides de referência são processadas e filtradas, incluindo quatro semanas de dados, para prever as correções das efemérides de referência e o comportamento dos relógios dos satélites.

Este método envolve também as observações de pseudodistância dos satélites nas estações de monitoramento, que são corrigidas da refração troposférica e ionosférica, e dos efeitos relativistas. As previsões são transmitidas aos satélites pelo menos uma vez ao dia.

\subsubsection{EFEMÉRIDES PRECISAS}

As efemérides pós-processadas, conhecidas como efemérides precisas, são corrigidas dos efeitos de perturbação da órbita após a passagem dos satélites, ficando disponíveis posteriormente aos usuários, e portanto, não são transmitidas pelos satélites (GEMAEL, 2004). As efemérides precisas visam atender usuários que necessitam de posicionamento com melhor precisão do que a oferecida pelas efemérides transmitidas.

No passado, este tipo de efemérides era oferecido apenas para usuários autorizados. Em virtude disso várias instituições civis concentraram seus esforços 
para organizar uma rede civil, criando em 1990 a Cooperative International GPS NETwork (CIGNET), sob a coordenação do US National Geodetic Survey (NGS) (MONICO, 2000).

A rede CIGNET foi incorporada ao International GNSS Service (IGS), que é uma federação voluntária que conta com 384 estações distribuídas globalmente. Atualmente (maio/2007), deste total de 384 estações, 338 geram dados e produtos precisos destinados aos usuários dos sistemas de posicionamento GPS e GLONASS. O IGS fornece estes dados e produtos, dentre eles as efemérides precisas, visando principalmente atender instituições de pesquisa e ensino. Atualmente existem 10 centros de análises, sendo: um na Suíça, dois na Alemanha, um no Canadá, um na República Tcheca e cinco nos Estados Unidos (INTERNATIONAL GNSS SERVICE, 2006).

A partir das órbitas produzidas pelos vários centros, são realizadas combinações, resultando em três tipos de efemérides: IGU, IGR e IGS, sendo:

- IGU (IGS Ultra-rapid): ficam disponíveis aos usuários com antecedência de algumas horas, no dia a que se refere;

- IGR (IGS Rapid): são disponibilizadas dentro de até 17 horas depois do horário de coleta dos dados pelo usuário;

- IGS (IGS Final): a mais precisa das três, demora cerca de 3 semanas após a data de coleta dos dados para estar disponível aos usuários.

O Quadro 1 mostra os padrões de exatidão da órbita e do relógio para cada tipo de efemérides.

\begin{tabular}{|c|c|c|}
\hline \multirow{2}{*}{ Efemérides } & \multicolumn{2}{|c|}{ Exatidão } \\
\cline { 2 - 3 } & Órbita & Relógio \\
\hline Transmitida & $\sim 160 \mathrm{~cm}$ & $\sim 7 \mathrm{~ns}$ \\
\hline Ultra-rápida & $<5 \mathrm{~cm}$ & $\sim 0,2 \mathrm{~ns}$ \\
\hline Rápida & $<5 \mathrm{~cm}$ & $0,1 \mathrm{~ns}$ \\
\hline Final & $<5 \mathrm{~cm}$ & $<0,1 \mathrm{~ns}$ \\
\hline
\end{tabular}

Quadro 1 - Exatidão das efemérides

Fonte: International GNSS Service, 2006 


\subsubsection{MÉtodos de POSICIONAMENTO POR GPS}

Ao se utilizar o sistema GPS na determinação da posição de objetos, é possível realizar o posicionamento de duas maneiras: a absoluta e a relativa.

O posicionamento absoluto, também conhecido como posicionamento por ponto, é realizado utilizando apenas um receptor, sendo suas coordenadas determinadas à partir das coordenadas dos satélites, calculadas com as efemérides transmitidas nas mensagens de navegação. Pode-se também utilizar as efemérides precisas para o cálculo das coordenadas e as correções dos relógios dos satélites, disponibilizadas pelo IGS. Neste caso, utilizando-se efemérides precisas, o posicionamento absoluto é dito "Posicionamento Preciso por Ponto" (PPP), chegando a alcançar precisão igual, ou melhor, que 1 metro (SILVA, 2005). A Figura 3 ilustra a condição mínima para que se possa realizar o posicionamento absoluto.

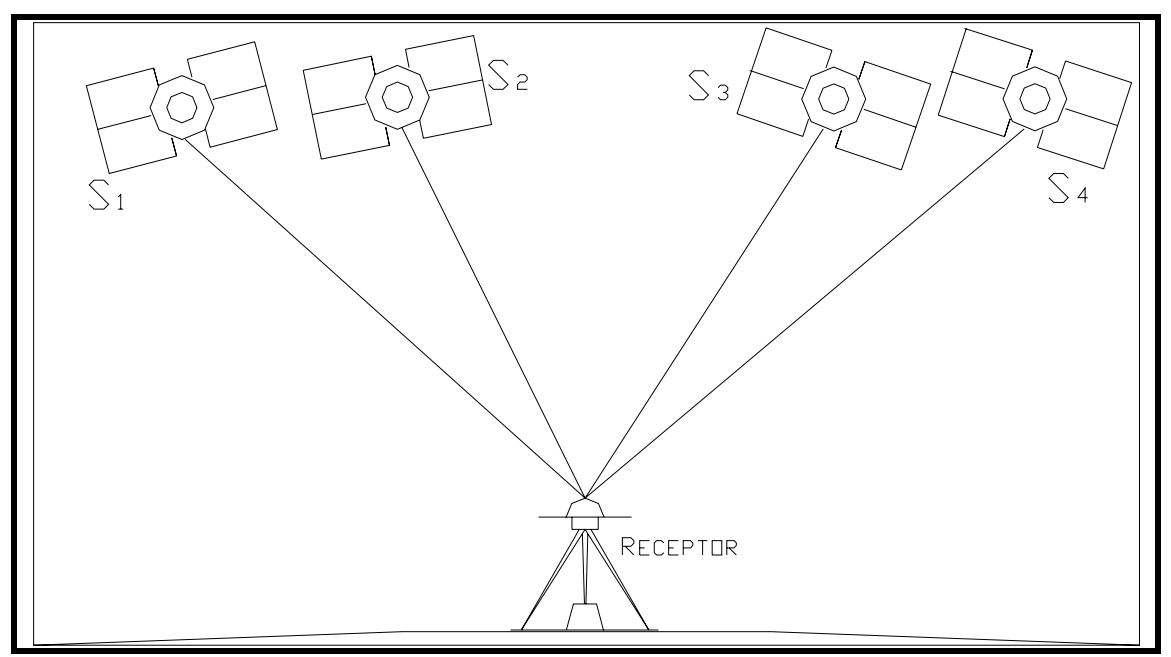

Figura 3: Posicionamento absoluto

O posicionamento relativo é uma técnica onde dois ou mais receptores são utilizados. Quando se realiza o posicionamento relativo objetiva-se determinar as coordenadas de um novo ponto a partir de um ou mais pontos de coordenadas conhecidas, ou seja, deseja-se determinar um vetor entre dois ou mais pontos (linha de base) formado por pelo menos 2 receptores GPS coletando informações simultaneamente (HOFMANN-WELLENHOF et al., 1997).

Atualmente, devido a criação e a grande utilização dos Sistemas de Controle Ativo (SCA), pode-se utilizar apenas um receptor para realizar o posicionamento 
relativo, desde que se utilize também dados coletados simultaneamente em uma estação contínua, pertencente a uma rede ativa. No Brasil, a principal rede ativa é materializada pela RBMC, gerenciada pelo IBGE, disponibiliza aos usuários dados coletados ininterruptamente por 24 estações distribuídas em todo o território nacional. Um breve histórico e as características da RBMC podem ser vistos na seção (3.1). No Brasil, existem outras redes ativas, dentre as quais podemos citar: a RIBaC (Rede INCRA de Bases Comunitárias do GPS) pertencente ao Instituto Nacional de Colonização e Reforma Agrária (INCRA), e a SCNet - Rede de Estações Ativas da Santiago \& Cintra, pertencente à empresa privada Santiago \& Cintra.

O posicionamento relativo pode ser dividido em vários métodos que dependem das necessidades do usuário, dentre os quais podem ser citados: o posicionamento estático, o estático rápido, o semicinemático e o cinemático. Mais detalhes sobre os métodos podem ser encontrados em Hofmann-Wellenhof et al. (1997), Monico (2000) e Seeber (2003).

A exatidão do posicionamento relativo é melhor do que a obtida por posicionamento absoluto, pois minimiza o efeito dos erros sistemáticos. Em levantamentos de alta precisão utiliza-se o posicionamento relativo observando-se a fase da onda portadora, pois como já foi dito anteriormente, esta é muito mais precisa que a pseudodistância.

Se no posicionamento estiverem envolvidos apenas 2 receptores, o processo é chamado de "posicionamento com base simples", se estiverem envolvidos 3 ou mais receptores é chamado de posicionamento com bases múltiplas (RODRIGUES, 2002).

\subsubsection{Combinações LINEARES ENTRE AS OBSERVÁVEIS GPS}

No processamento de dados GPS, coletados utilizando a técnica de posicionamento relativo, as observações GPS podem ser diferenciadas entre receptores, satélites e entre diferentes épocas de medição, permitindo ao usuário montar diversas combinações lineares, que variam de acordo com a sua 
necessidade. Dentre as várias combinações possíveis, três são as mais utilizadas: a simples, a dupla e a tripla diferença, sendo que as duas últimas são derivadas da primeira (SEEBER, 2003).

\subsubsection{SIMPLES DIFERENÇA}

Simples diferenças podem ser formadas entre dois receptores, dois satélites ou duas épocas. A teoria básica é que dois receptores rastreiem o mesmo satélite simultaneamente (MONICO, 2000), como pode ser visto na Figura 4.

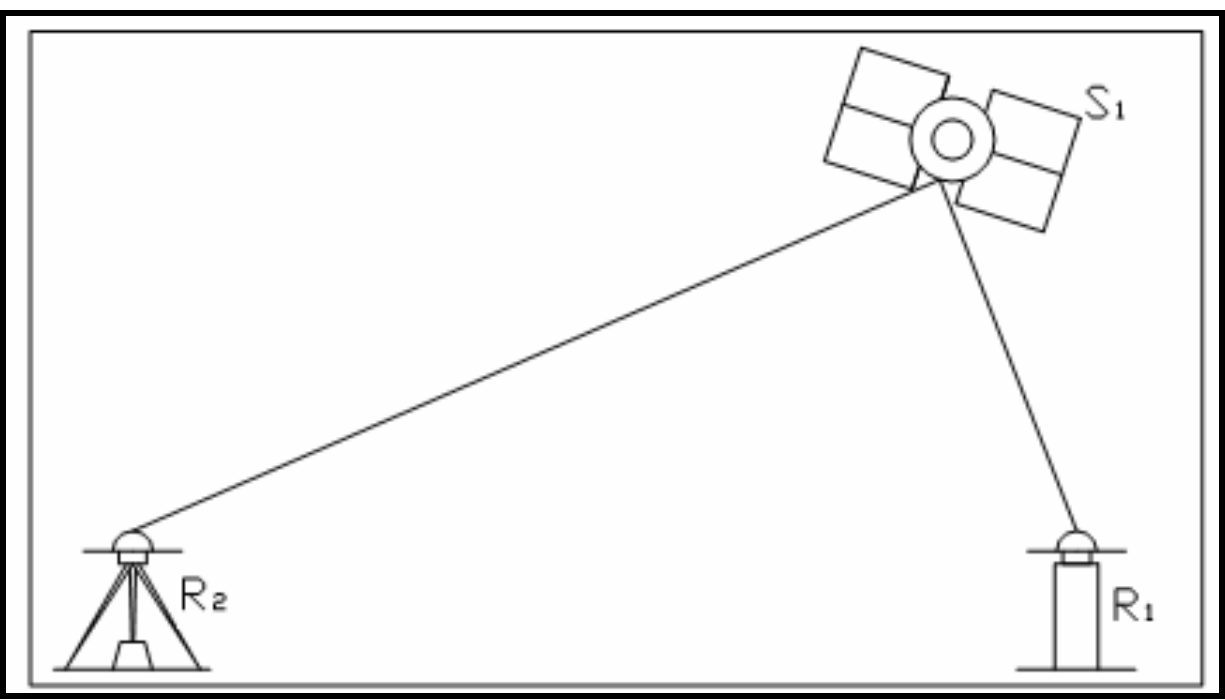

Figura 4: Simples diferença

Nessa combinação o erro do relógio do satélite é eliminado. Erros inerentes à posição dos satélites e à refração atmosférica são minimizados especialmente em bases curtas, isto é, menores que $10 \mathrm{~km}$, pois, assume-se que, neste caso, como os sinais percorrem a camada atmosférica em regiões bem próximas, os efeitos causados pelas refrações ionosférica e troposférica serão iguais, anulando-se (SANTOS, 1990). Para bases longas a refração troposférica pode ser modelada e a ionosférica minimizada, através da utilização das duas portadoras (MONICO, 2000).

A equação de observação de simples diferença para a pseudodistância é dada por (MONICO, 2000): 


$$
\Delta P D_{1,2}^{1}+v_{P D_{S D}}=\Delta \rho_{1,2}^{1}+c\left(\delta \tau_{1}-\delta \tau_{2}\right)
$$

sendo que:

$$
\begin{gathered}
\Delta P D_{1,2}^{1}=P D_{1}^{1}-P D_{2}^{1} \\
\Delta \rho_{1,2}^{1}=\rho_{1}^{1}-\rho_{2}^{1}
\end{gathered}
$$

onde:

$\triangle \mathrm{PD}$ - diferença entre as pseudodistâncias calculadas;

$\mathrm{V}_{\mathrm{PD}_{\mathrm{SD}}}$ - resíduos não modelados da pseudodistância;

PD - pseudodistância;

c - velocidade da luz;

$\tau$ - intervalo de tempo de propagação do sinal;

$\Delta \rho$ - diferença entre as distâncias geométricas calculadas;

$\rho$ - distância geométrica.

Para a fase da onda portadora temos a seguinte equação de observação para a simples diferença (MONICO, 2000):

$$
\Delta \phi_{1,2}^{1}+\mathrm{v}_{\phi_{\mathrm{SD}}}=\frac{\mathrm{f}}{\mathrm{c}} \Delta \rho_{1,2}^{1}+\mathrm{f}\left(\delta \tau_{1}-\delta \tau_{2}\right)+\Delta \mathrm{N}_{1,2}^{1}
$$

onde:

$$
\begin{gathered}
\phi_{1,2}\left(\mathrm{t}_{0}\right)=\phi_{1}\left(\mathrm{t}_{0}\right)-\phi_{2}\left(\mathrm{t}_{0}\right) \\
\Delta \mathrm{N}_{1,2}^{1}=\mathrm{N}_{1}^{1}-\mathrm{N}_{2}^{1}
\end{gathered}
$$

sendo:

$\Delta \phi$ - diferença entre as fases determinadas;

$\mathrm{v}_{\phi_{\mathrm{SD}}}$ - resíduos não modelados da fase;

$\phi$ - fase da onda portadora;

f - freqüência da observável considerada; 
c - velocidade da luz;

$\tau$ - intervalo de tempo de propagação do sinal;

$\Delta \rho$ - diferença entre as distâncias geométricas calculadas;

$\Delta \mathrm{N}$ - diferença entre as ambigüidades determinadas;

$\mathrm{N}$ - ambigüidade;

$\mathrm{t}_{0}$ - época de referência.

\subsubsection{DUPLA DIFERENÇA}

A dupla diferença é a diferença entre duas simples diferenças e envolve, portanto, dois receptores e dois satélites, como pode ser visto na Figura 5.

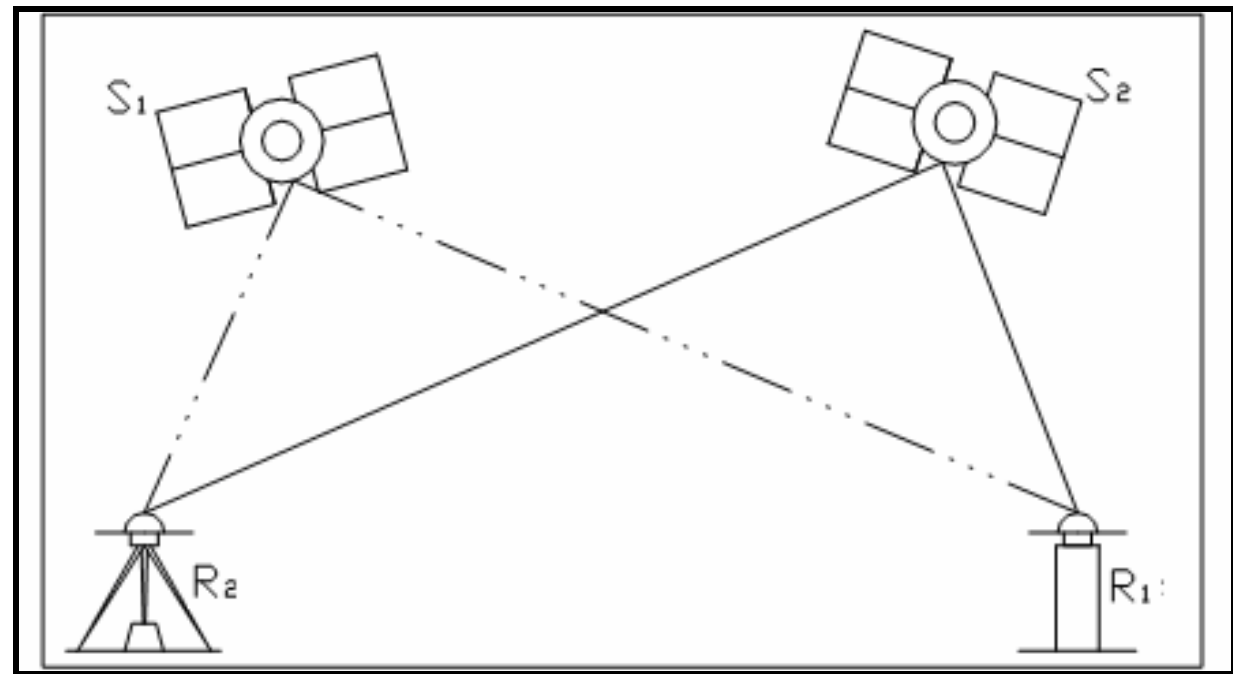

Figura 5: Dupla diferença

A equação de observação da dupla diferença para a pseudodistância é dada por (Monico, 2000):

$$
\Delta \mathrm{PD}_{1,2}^{1,2}+\mathrm{v}_{\mathrm{PD}_{\mathrm{DD}}}=\Delta \rho_{1,2}^{1,2}
$$

tem-se que:

$$
\Delta \rho_{1,2}^{1,2}=\Delta \rho_{1,2}^{1}-\Delta \rho_{1,2}^{2}
$$

sendo: 
$\triangle P D$ - diferença entre as pseudodistâncias calculadas;

$V_{P D_{D D}}$ - resíduos não modelados da pseudodistância;

$P D$ - pseudodistância;

$\Delta \rho$ - diferença entre as distâncias geométricas calculadas;

A equação de observação da dupla diferença para a fase de batimento da onda portadora é dada por (MONICO, 2000):

$$
\Delta \phi_{1,2}^{1,2}=\frac{\mathrm{f}}{\mathrm{c}}\left(\Delta \rho_{1,2}^{1,2}\right)+\mathrm{N}_{1,2}^{1,2}+\mathrm{v}_{\phi_{\mathrm{DD}}}
$$

com

$$
N_{1,2}^{1,2}=N_{1}^{1}-N_{2}^{1}-N_{1}^{2}+N_{2}^{2}
$$

tem-se que:

$\Delta \phi$ - diferença entre as fases determinadas;

$\mathrm{v}_{\phi_{\mathrm{DD}}}$ - resíduos não modelados da fase;

$\phi$ - fase da onda portadora;

f - freqüência da observável considerada;

c - velocidade da luz;

$\Delta \rho$ - diferença entre as distâncias geométricas calculadas;

$\Delta \mathrm{N}$ - diferença entre as ambigüidades determinadas;

$\mathrm{N}$ - ambigüidade;

O termo $N_{1,2}^{1,2}$ é a ambigüidade da dupla diferença, e é suposto ser um número inteiro.

Esta é a combinação mais comumente utilizada no processamento dos dados GPS que envolva a fase da onda portadora, em virtude da qualidade dos resultados que podem ser obtidos (GEMAEL, 2004). Proporciona melhor relação entre o ruído 
resultante e a eliminação de erros sistemáticos envolvidos nas observáveis originais (MONICO, 2000).

Assumindo que as freqüências dos osciladores dos dois satélites são idênticas e que as observações são simultâneas, para esta observação, os efeitos das instabilidades dos osciladores dos satélites e receptores desaparecem (HOFMANNWELLENHOF et al., 1997). Por ser pouco sensível às instabilidades dos osciladores dos satélites e dos receptores, a dupla diferença de fase torna-se muito útil na fixação de perdas de ciclos (RODRIGUES, 2002).

\subsubsection{TRIPLA DIFERENÇA}

A tripla diferença é calculada pela diferença entre duplas diferenças em épocas distintas (t1 e t2), Figura 6.

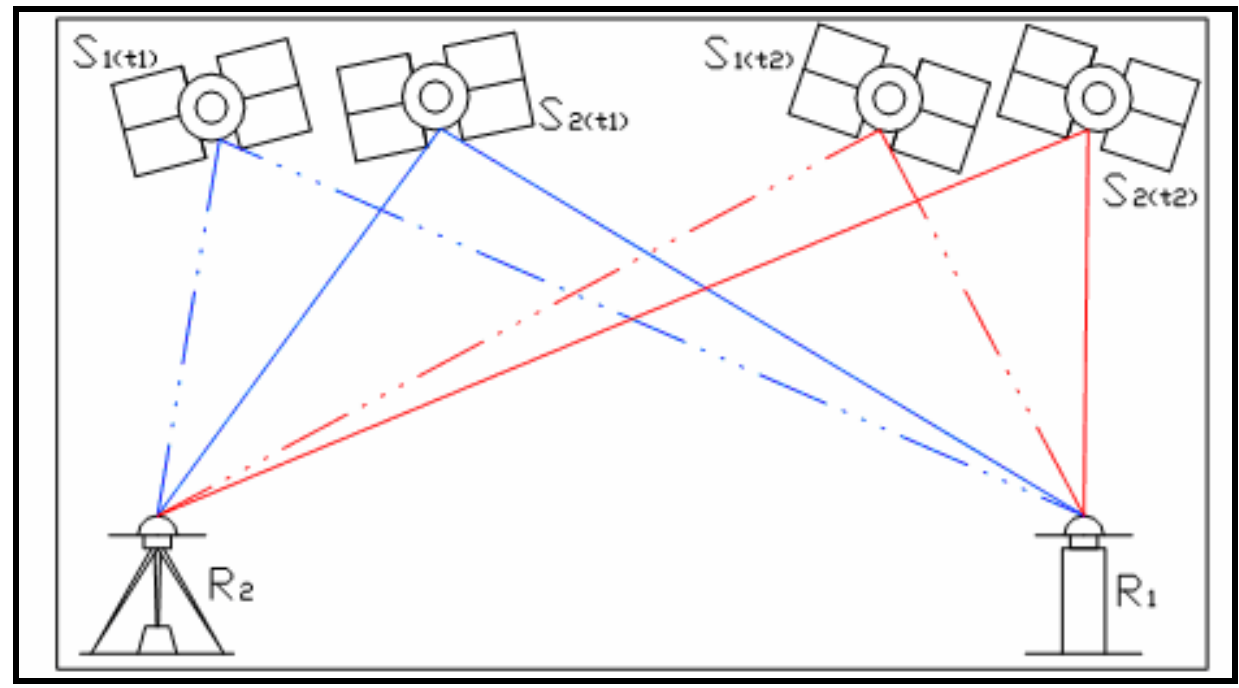

Figura 6: Tripla diferença

Apresenta vantagem apenas para a fase da portadora, já que a ambigüidade é eliminada, restando como incógnitas apenas as coordenadas do receptor. Este algoritmo apresenta maior ruído na observável resultante e grande correlação temporal entre épocas distintas (MONICO, 2000), mas, apesar disso, é um ótimo método para se realizar o pré-processamento e geralmente é utilizado pelos programas de processamento para se detectar perdas de ciclos e erros grosseiros. 
Segundo Monico, 2000, sua equação é dada por:

$$
\Delta \phi_{1,2}^{1,2}\left(\mathrm{t}_{1}\right)-\Delta \phi_{1,2}^{1,2}\left(\mathrm{t}_{2}\right)+\mathrm{v}_{\phi_{\text {TD }}}=\frac{\mathrm{f}}{\mathrm{c}}\left[\Delta \rho_{1,2}^{1,2}\left(\mathrm{t}_{1}\right)-\Delta \rho_{1,2}^{1,2}\left(\mathrm{t}_{2}\right)\right]
$$

sendo:

$\Delta \phi$ - diferença entre as fases determinadas;

$\mathrm{v}_{\phi_{\mathrm{TD}}}$ - resíduos não modelados da fase;

$\phi$ - fase da onda portadora;

f - freqüência da observável considerada;

c - velocidade da luz;

$\Delta \rho$ - diferença entre as distâncias geométricas calculadas;

$\mathrm{t}$ - época de referência.

\subsubsection{DILUIÇÃo dA PRECISÃo (DOP)}

A geometria dos satélites é um fator a ser levado em consideração para se conseguir maior exatidão na determinação das coordenadas de um ponto, já que ela se modifica constantemente devido ao movimento dos satélites e ao movimento de rotação da Terra. Um dos fatores para se estimar a qualidade das observações é a geometria denominada por "fator de diluição de precisão", ou simplesmente DOP.

Segundo Seeber (2003) a exatidão do posicionamento depende de 2 fatores:

- A exatidão da medição de pseudodistância expressa pelo User Equivalent Range Error (UERE), que está associado ao desvio padrão da observação $\left(\sigma_{\mathrm{r}}\right)$;

- A configuração dos satélites observados ou rastreados (DOP).

O UERE é composto por todos os erros que contribuem para incrementar o erro posicional de um receptor GPS no modo absoluto, sendo expresso como um erro equivalente à distância entre o receptor GPS e um satélite. O erro denominado UERE é originado de diferentes fontes independentes entre si, sendo que, seu valor 
total pode ser calculado pela raiz quadrada da soma dos quadrados dos erros individuais. (ROYAL OBSERVATORY OF BELGIUM, 2007).

A relação entre $\sigma_{r}$ e o desvio padrão associado do posicionamento $\left(\sigma_{p}\right)$ é descrito quantitativamente por um escalar utilizado freqüentemente na navegação, denominado DOP, que pode ser determinado conforme a equação (SEEBER, 2003):

$$
\sigma_{\mathrm{P}}=\mathrm{DOP} * \sigma_{\mathrm{r}} \Rightarrow \mathrm{DOP}=\frac{\sigma_{\mathrm{P}}}{\sigma_{\mathrm{r}}}
$$

Dependendo do fim a que o levantamento se destina pode-se utilizar um desses DOP:

- PDOP: diluição da precisão em posicionamento tridimensional;

- VDOP: diluição da precisão em altimetria;

- HDOP: diluição da precisão em planimetria;

- TDOP: diluição da precisão para determinação de tempo;

- GDOP: diluição da precisão resultante da combinação entre PDOP e TDOP;

- RDOP: diluição da precisão relativa entre 2 pontos.

O PDOP é um dos fatores mais utilizados, e pode ser interpretado geometricamente como sendo o inverso do volume $(V)$ de um tetraedro formado entre o receptor e 4 satélites visíveis, conforme equação (2.25) e figura 7. A melhor geometria ocorre quando o volume é máximo, resultando em um valor de DOP mínimo (Monico, 2000).

$$
\text { PDOP } \alpha \frac{1}{\mathrm{~V}}
$$




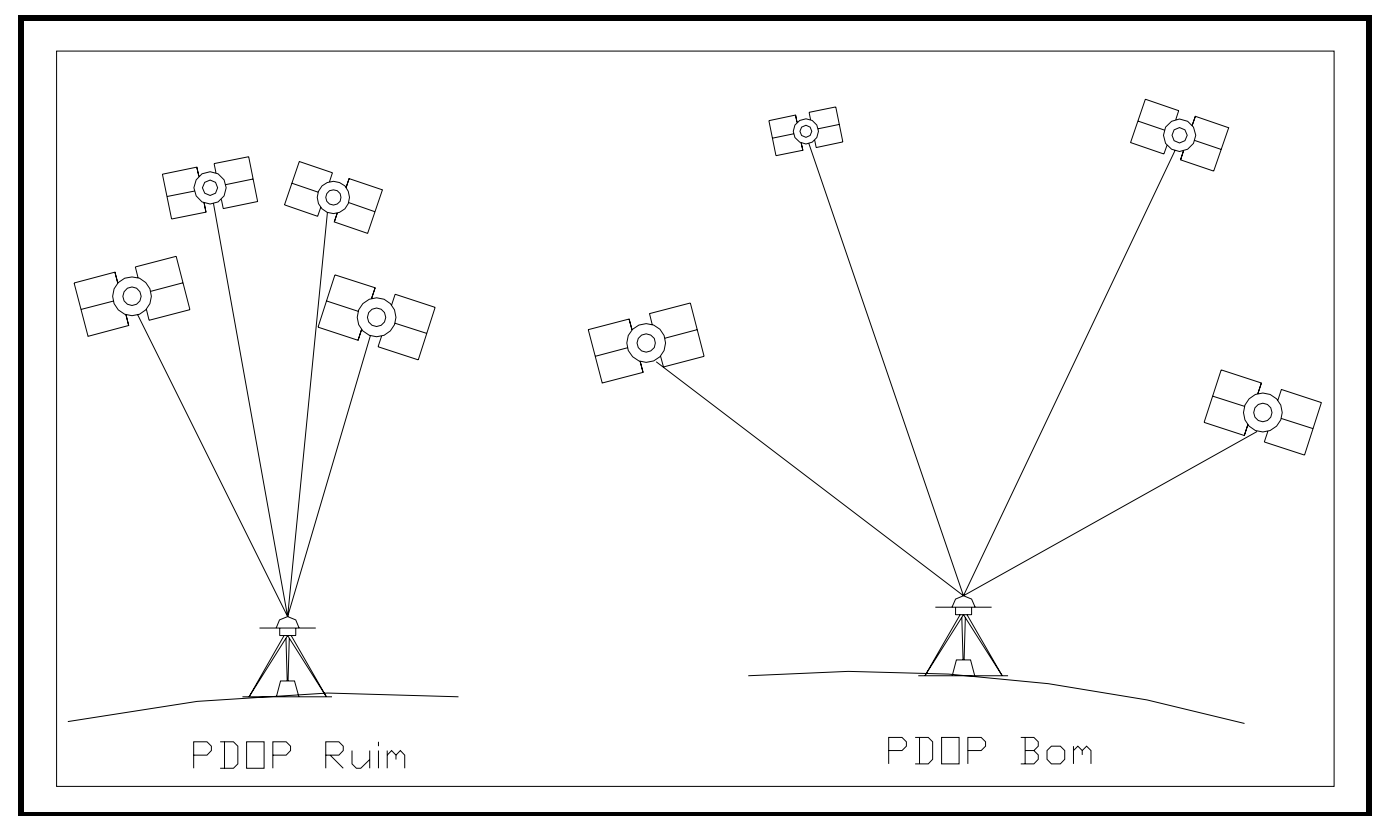

Figura 7: Geometria dos satélites

Ao se utilizar o posicionamento relativo, a grandeza analisada deve ser o RDOP, já que os demais fatores são de grande valia para o posicionamento absoluto. O fator RDOP serve para avaliar as observações realizadas no modo relativo, sendo que, o mesmo pode ser calculado através da seguinte equação (GOAD, 1988 apud SEEBER, 2003):

$$
\mathrm{RDOP}=\sqrt{\operatorname{tr}\left(\mathrm{A}^{\mathrm{T}} \Sigma^{-1} \mathrm{~A}\right)^{-1} / \sigma_{\mathrm{DD}}^{2}}
$$

onde:

$\left(\mathrm{A}^{\mathrm{T}} \Sigma^{-1} \mathrm{~A}\right)^{-1}$ - matriz de covariância;

$\sigma_{\mathrm{DD}}$ - incerteza na medida de dupla diferença;

$\Sigma$ - matriz de covariância da dupla diferença;

A - matriz das derivadas parciais das duplas diferenças.

Existem programas que permitem verificar os valores de DOP ao longo do dia, quantidade de satélites visíveis, elevação dos satélites e outros indicativos, para um período pré-definido pelo usuário. Para executar este planejamento é necessário que se disponha de um arquivo de efemérides recente, pois, o mesmo informará a 
existência de satélites com problemas e desativados, condição importante para o planejamento do rastreio.

\subsubsection{ERROS ENVOLVIDOS NAS OBSERVÁVEIS GPS}

As observáveis GPS estão sujeitas aos erros aleatórios, sistemáticos e grosseiros. Os erros sistemáticos são aqueles que têm suas causas conhecidas e podem ser modelados como termos adicionais ou eliminados por técnicas apropriadas de observação e/ou processamento. Os erros aleatórios não podem ser modelados, e por isso, são considerados uma característica da observação. Os erros grosseiros, geralmente, são os erros introduzidos por falhas humanas na operação do instrumento e podem ser detectados através da realização de várias sessões de coleta sobre o mesmo ponto e minimizados por observadores cuidadosos.

Os diversos erros que afetam as observáveis GPS são apresentados no Quadro 2. As fontes consideradas são os satélites, a propagação do sinal, o conjunto receptor/antena e a própria estação.

Os erros aqui citados são inerentes também aos sistemas de posicionamento GLONASS (ver seção 2.2) e GALILEO (ver seção 2.3).

A modelagem e o tratamento desses erros são de extrema importância para que se possa obter maior exatidão e menor incerteza nas medidas. Muitos deles são praticamente eliminados quando se realiza o posicionamento relativo ou pela combinação linear entre as portadoras L1 e L2. Outros são minimizados utilizandose um modelo matemático adequado (MATSUOKA, 2003). 


\begin{tabular}{|c|c|c|c|}
\hline FONTES & EFEITOS & TIPO DE EFEITO & MAGNITUDE DO EFEITO $(1 \sigma)$ \\
\hline \multirow{4}{*}{ Satélite } & Erro da órbita & Sistemático & $\begin{array}{l}\text { Até } 160 \mathrm{~cm} \text { (INTERNATIONAL GNSS } \\
\text { SERVICE, 2006) }\end{array}$ \\
\hline & Erro do relógio & Sistemático & $\begin{array}{l}\text { Até } 7 \text { ns (INTERNATIONAL GNSS } \\
\text { SERVICE, 2006) }\end{array}$ \\
\hline & Relatividade & Sistemático & $\begin{array}{l}\text { Até } 18,7 \text { mm no sinal GPS } \\
\text { (HOFMANN-WELLENHOF et al., } \\
\text { 1997). Este efeito é compensado } \\
\text { antes do lançamento do satélite, } \\
\text { reduzindo a freqüência dos relógios } \\
\text { dos mesmos (MONICO, 2000) }\end{array}$ \\
\hline & $\begin{array}{l}\text { Atraso entre as duas } \\
\text { portadoras no } \\
\text { hardware do satélite }\end{array}$ & Sistemático & $\begin{array}{l}\text { Determinada na calibração dos } \\
\text { satélites e corrigida através de } \\
\text { informação inserida na mensagem de } \\
\text { navegação (MONICO, 2000) }\end{array}$ \\
\hline \multirow{4}{*}{$\begin{array}{l}\text { Propagação } \\
\text { do sinal }\end{array}$} & Refração troposférica & Sistemático & $\begin{array}{l}\text { Varia de acordo com a elevação do } \\
\text { satélite, gerando uma incerteza de } \\
2,3 \text { a } 20 \text { m nos sinais GPS (SEBEER, } \\
2003 \text { ) }\end{array}$ \\
\hline & Refração ionosférica & Sistemático & $\begin{array}{l}1-100 \mathrm{~m} \text { (1 a } 2 \text { ppm linha de base) } \\
\text { (SEBEER, 2003) }\end{array}$ \\
\hline & Perdas de ciclos & Sistemático & Depende do $\mathrm{n}^{\circ}$ de ciclos perdidos \\
\hline & Rotação da Terra & Sistemático & $\begin{array}{l}\text { Erro angular de } \approx 1,25 " \text {. Corrigida } \\
\text { através da rotação das coordenadas } \\
\text { do satélite sobre o eixo Z deste valor. } \\
\text { (MONICO, 2000) }\end{array}$ \\
\hline \multirow{4}{*}{$\begin{array}{l}\text { Receptor/ } \\
\text { antena }\end{array}$} & Erro do relógio & Sistemático & $\begin{array}{l}3 \text { horas de rastreio pode gerar um } \\
\text { erro aproximado de } 10 \mathrm{~ns}(30 \mathrm{~cm}) \\
\text { (HOFMANN-WELLENHOF et al., } \\
\text { 1997) }\end{array}$ \\
\hline & Erro do hardware & Sistemático & Depende do receptor \\
\hline & Erro entre os canais & Sistemático & Depende do receptor \\
\hline & $\begin{array}{l}\text { Centro de fase da } \\
\text { antena }\end{array}$ & Sistemático & $\begin{array}{l}\text { Depende da antena utilizada, sendo } \\
\text { geralmente menor que } 7 \mathrm{~cm} \text {. }\end{array}$ \\
\hline \multirow{9}{*}{ Estação } & Erro nas coordenadas & Grosseiro & $\begin{array}{l}\text { Erro de } 5 \mathrm{~m} \text { na estação base, gera } \\
\text { até } 1 \mathrm{ppm} \text { em }(\Delta \phi, \Delta \lambda \text { e } \Delta \mathrm{h}) \\
(\mathrm{MONICO}, 2000)\end{array}$ \\
\hline & Multicaminho & Sistemático & Até $1 / 4 \lambda$ (SEEBER, 2003) \\
\hline & Marés terrestres & Sistemático & $\begin{array}{l}\text { Até } 5 \mathrm{~cm} \text { em } \phi, \lambda \text { e } 30 \mathrm{~cm} \text { em h } \\
\text { (INSTITUTO GEOGRÁFICO } \\
\text { NACIONAL, 2006) }\end{array}$ \\
\hline & $\begin{array}{l}\text { Tectônica de placas } \\
\text { litosféricas }\end{array}$ & Sistemático & $\begin{array}{l}\text { Depende da região, máximo de } 7 \\
\text { cm/ano (INSTITUTO GEOGRÁFICO } \\
\text { NACIONAL, 2006) }\end{array}$ \\
\hline & Movimento do Pólo & Sistemático & $\begin{array}{l}\text { Amplitude máxima de até } 10 \mathrm{~m} \text { por } \\
\text { período de } 434 \text { dias (INSTITUTO } \\
\text { GEOGRÁFICO NACIONAL, 2006) } \\
\end{array}$ \\
\hline & Carga oceânica & Sistemático & Até $10 \mathrm{~cm} \mathrm{em} \mathrm{h}(\mathrm{MONICO}, 2000)$ \\
\hline & Carga atmosférica & Sistemático & Até $10 \mathrm{~mm}$ em h (MONICO, 2000) \\
\hline & $\begin{array}{l}\text { Identificação da } \\
\text { estação }\end{array}$ & Grosseiro & Não há como estimar \\
\hline & $\begin{array}{l}\text { Medição da altura da } \\
\text { antena }\end{array}$ & Grosseiro & Não há como estimar \\
\hline
\end{tabular}

Quadro 2 - Fontes e efeitos dos erros envolvidos nas observáveis GPS

Fonte: Adaptado de Monico, 2000 
A seguir serão descritos os erros que podem acarretar maiores incertezas nas medições. Informações mais detalhadas com relação as fontes e os efeitos dos erros envolvidos no GPS podem ser encontrados em Leick (1995), HofmannWellenhof et al. (1997), Monico (2000) e Seeber (2003).

\subsubsection{EFEITOS RELACIONADOS COM A PROPAGAÇÃo do SinAL}

Os sinais provenientes dos satélites atravessam diferentes camadas antes de chegarem ao receptor do usuário, sofrendo variações em sua direção e velocidade de propagação, em sua polarização e em sua potência (SEEBER, 2003), além da possibilidade de sofrer obstrução e reflexão ocasionadas por objetos que estejam próximos à antena. Neste item serão apresentados mais detalhadamente os erros de refração troposférica e ionosférica, de perdas de ciclos e de multicaminho, que são classificados como erros que afetam a propagação do sinal.

\subsection{CORREÇõEs AtMOSFÉRICAS}

Os sinais dos satélites, ao percorrerem seu caminho rumo à superfície terrestre atravessam diferentes camadas naturais, sofrendo interferências que provocam variações em sua direção e velocidade de propagação, além de afetar na polarização e potência do sinal (SEEBER, 2003).

A atmosfera, para efeitos práticos, em relação à propagação de sinais é subdividida em troposfera e ionosfera (figura 8), e como elas apresentam características diferentes, serão apresentadas à seguir separadamente. 


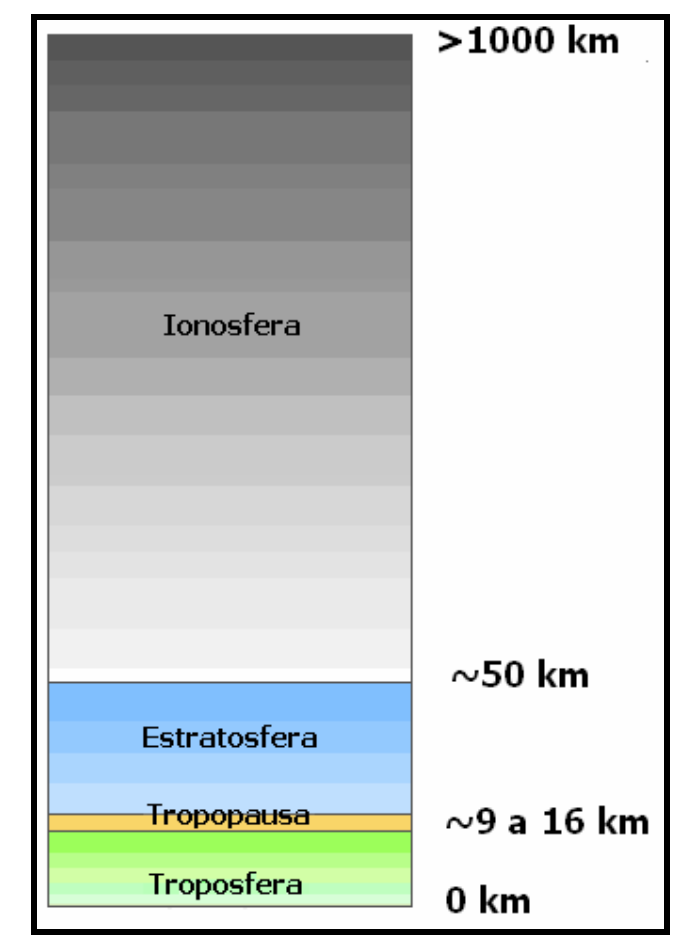

Figura 8: Camadas da Atmosfera Terrestre Fonte: Adaptada de Liu, 2001

\subsection{REFRAÇÃO TROPOSFÉRICA}

A troposfera é a camada da atmosfera que se encontra mais próxima da superfície terrestre, e abrange altitude aproximada de $9 \mathrm{~km}$ nos pólos e $16 \mathrm{~km}$ na região equatorial, sendo esta região variável conhecida como tropopausa (LIU, 2001). Comporta-se, como um meio onde a refração independe da freqüência do sinal transmitido, desde que a mesma seja inferior a $30 \mathrm{GHz}$ (LEICK, 1995), e que devido à sua dinâmica torna-se difícil modelar seu índice de refração.

O efeito da troposfera sobre a distância GPS pode variar de poucos metros a até 20 metros, esta variação ocorre devido à mudanças na densidade da atmosfera e ao ângulo de elevação do satélite.

A minimização do efeito da refração troposférica pode ser feita por meio de técnicas de processamento, ou por meio de modelos (MATSUOKA, 2003). Desta forma, muitos modelos foram desenvolvidos de modo a tentar representar o comportamento da refratividade em relação a altura. Os primeiros estudos partiram de Hopfield, entre os anos de 1969 a 1971, e o modelo por ela desenvolvido, após 
algumas modificações e adaptações continua sendo utilizado (FONSECA Jr., 2002). Vários outros modelos foram desenvolvidos e podem ser encontrados em Saastamoinem (1973), Black (1984), Rothacher et al. (1986) e Niell (1996). Além destes modelos, o CPTEC/INPE (Centro de Previsão de Tempo e Estudos Climáticos / Instituto Nacional de Pesquisas Espaciais) disponibiliza o Modelo do Atraso Zenital Troposférico para os sistemas de posicionamento por satélites GPS e GLONASS.

\subsection{REFRAÇÃO IONOSFÉRICA}

A ionosfera está localizada na parte superior da atmosfera terrestre, e compreende a região situada aproximadamente entre 50 km / 70 km e 1000 km acima da superfície terrestre, e tem por característica a presença de partículas livres e carregadas (íons) que afetam a propagação do sinal (FONSECA Jr., 2002).

A ionosfera, como um meio dispersivo, afeta a modulação e a fase da onda portadora, fazendo com que sofram, respectivamente, um atraso e um avanço (LEICK, 1995).

A refração ionosférica depende diretamente da freqüência do sinal, e o efeito da refração tem relação com o TEC (Total Electron Content), ou seja, é afetado proporcionalmente pela quantidade de elétrons presentes no caminho percorrido pelo sinal entre o satélite e o receptor.

O grande problema para a modelagem da refração ionosférica é que o TEC varia no tempo e no espaço, sendo afetado pelo fluxo de ionização solar, atividade geomagnética, ciclo de manchas solares, estação do ano, localização do usuário e direção do raio vetor satélite-receptor (CAMARGO, 1999).

A cintilação é um fenômeno que ocorre na ionosfera e afeta os sinais GPS e consiste de uma rápida variação na amplitude e fase dos sinais, fazendo com que o receptor perca a sintonia com o satélite devido ao enfraquecimento do sinal (WANNINGER, 1992 apud FONSECA Jr., 2002).

A cintilação é causada por estruturas irregulares de plasma de centenas de metros. Este fato ocorre preferencialmente na faixa de $+30^{\circ}$ a $-30^{\circ}$ de latitude, sendo 
que os eventos de maior intensidade ocorrem na zona entre $+10^{\circ}$ e $-10^{\circ}$ de latitude a partir da linha do equador geomagnético (WANNINGER, 1993 apud FONSECA Jr., 2002).

No Brasil, assim como em todo o continente americano, os efeitos da cintilação são máximos entre os meses de setembro e março, e mínimos entre os meses de abril a agosto (CAMPOS et al., 1993 apud FONSECA Jr., 2002).

É importante lembrar que, no posicionamento relativo com distâncias de até 20 km entre as estações, grande parte dos erros causados pela refração ionosférica são minimizados devido à alta correlação existente entre as estações. Com o aumento da distância entre as estações, os erros passam a ter sua correlação reduzida. Neste caso, a utilização de um modelo da ionosfera se faz necessário.

Pode-se também minimizar ou eliminar os efeitos da refração ionosférica utilizando receptores de dupla freqüência. A partir da combinação das observações das portadoras L1 e L2 pode-se gerar um comprimento de onda menor, resultando em uma maior freqüência. Isto se deve ao fato da refração ionosférica ser inversamente proporcional ao quadrado da freqüência, portanto, freqüências mais altas são menos afetadas (SEEBER, 2003).

Mais detalhes sobre a ionosfera podem ser encontrados em: Camargo, 1999; Fonseca Jr., 2002; e Matsuoka, 2003.

\subsection{PERdAS de Ciclos}

Quando um receptor é ligado, a parte fracionária da fase da portadora (diferença entre a fase transmitida pelo satélite e recebida pelo receptor, e sua réplica gerada pelo receptor) é observada e um contador inteiro é inicializado. Esse contador tem por fim acrescentar um ciclo sempre que houver uma mudança da fase de $2 \pi$ para 0 . A partir de então, para uma determinada época, a fase observada acumulada é a soma da parte fracionária com o número inteiro de ciclos (HOFMANN-WELLENHOF et al., 1997).

Em uma sessão de observação, as medidas efetuadas a partir da fase da onda portadora geralmente são contínuas. Quando há uma descontinuidade é 
caracterizada a perda de ciclo que pode ocorrer por diversos fatores, dentre os quais (SEEBER, 2003):

- Dependentes da observação:

- Obstruções, principalmente em levantamentos cinemáticos;

- Ruídos embutidos no sinal, causados principalmente por multicaminho e cintilação ionosférica;

- Variações bruscas ocorridas na troposfera e ionosfera e;

- Baixa elevação do satélite, que resulta em baixa potência do sinal.

- Dependente do receptor:

- Sinal enfraquecido devido à interferências e;

- Antenas inclinadas.

Quando a perda de ciclos ocorre, a contagem do número inteiro de ciclos sofre um salto, mas a parte fracionária da fase, nas observações que se seguem, não é afetada por este salto. Além disso, a existência de perda de ciclos pode resultar em dificuldades na solução das ambigüidades (LEICK, 1995).

Para detectar e corrigir a perda de ciclo é necessário primeiramente localizar o salto e determinar seu tamanho. Após sua detecção, as correções são feitas pelo acréscimo de um valor fixo em todas as observações de fase subseqüentes. Esse processo de determinação e correção é conhecido como fixação das perdas de ciclos (HOFMANN-WELLENHOF et al., 1997).

\subsection{MULTICAMINHO}

O multicaminho, também conhecido como multipercurso, ocorre quando um sinal enviado pelo satélite atinge um corpo qualquer e sofre um desvio (reflexão) antes que o mesmo chegue a antena do receptor. O sinal sofre desvios, principalmente, devido a objetos e obstruções próximos à estação, tais como: edificações, corpos d’água, cercas, árvores, etc. A Figura 9 representa a ocorrência de multicaminho.

O multicaminho afeta tanto as medições de código quanto as medições de fase da onda portadora, sendo que o efeito sobre a primeira observável é duas vezes 
maior em grandeza do que sobre a segunda (SEEBER, 2003). O efeito do multicaminho pode chegar a um valor de 10 a 20 metros para as pseudodistâncias medidas com o código (HOFMANN-WELLENHOF et al., 1997).

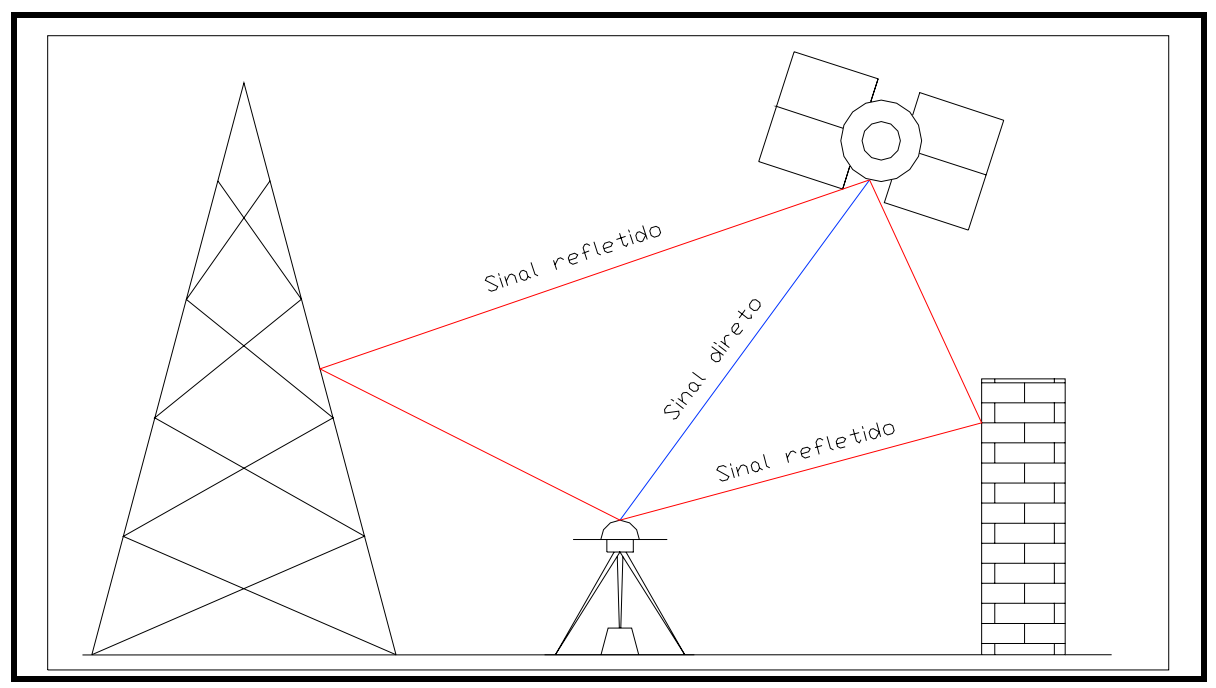

Figura 9: Multicaminho

O multicaminho é difícil de ser modelado, pois, depende, diretamente do ambiente onde está localizado o receptor. Portanto, é primordial ao se realizar o posicionamento, que se evitem locais favoráveis a este efeito, o que nem sempre é possível.

A seguir, são descritos alguns procedimentos que podem ser tomados de forma a diminuir o efeito do multicaminho, como:

- Utilização de antenas capazes de minimizar tal efeito, como as do tipo Choke-Ring (SEEBER, 2003);

- Utilização de receptores que possuam programas internos capazes de identificar e filtrar o multicaminho (MACHADO, 2002);

- Sinais de satélites em baixa elevação, em relação ao plano do horizonte, estão mais expostos a sofrerem efeitos de multicaminho, sendo importante a utilização de máscaras de elevação durante os rastreios, como, por exemplo, de $10^{\circ}$ a $15^{\circ}$ (SILVA, 2005);

- Escolha de locais abertos e desobstruídos (SEEBER, 2003).

Uma maneira de detecção do multicaminho é através da repetição de observações utilizando a mesma geometria entre a constelação de satélites e o receptor, ou seja, em dias siderais diferentes (LEICK, 1995). 


\subsubsection{CORREÇÕES GEOFÍSICAS RELACIONADAS COM A ESTAÇÃO}

As variações, resultantes de fenômenos geofísicos ocorridos durante o período de coleta das observações, podem afetar as coordenadas das estações envolvidas no levantamento. Estas variações, não se tratam especificamente de erros, mas de correções que devem ser aplicadas às observáveis, ou às coordenadas das estações, em levantamentos em que seja necessário atingir um alto nível de acurácia. A seguir, algumas destas correções são apresentadas.

\subsection{MOVIMENTO do Pólo}

A interseção do eixo instantâneo de rotação do globo terrestre se move ao longo do tempo, sendo denominado movimento do Pólo, e isto ocorre principalmente devido as propriedades elásticas da Terra (INSTITUTO GEOGRÁFICO NACIONAL, 2006).

É um movimento praticamente periódico, que pode ser modelado geofisicamente, ainda que, não de uma maneira completa. O monitoramento do movimento do Pólo é realizado pelo International Earth Rotation and Reference Systems Service (IERS) desde 1988, com o auxílio das tecnologias Very Long Baseline Interferometry (VLBI), Satellite Laser Range (SLR), Lunar Laser Range (LLR), GPS dentre outras (GEMAEL, 2004).

A fim de se evitar variações em latitude e longitude provenientes do movimento do Pólo, defini-se o "Conventional Terrestrial Pole" (CTP), fixado a crosta da Terra e definido como o Pólo médio entre os anos de 1900 e 1906 (INSTITUTO GEOGRÁFICO NACIONAL, 2006).

Em posicionamento geodésico de alta precisão, a correção do movimento do Pólo deve ser considerada, pois a mesma pode inserir uma incerteza de até $25 \mathrm{~mm}$ na componente radial, que não é cancelada com o aumento da duração da sessão. No entanto, utilizando-se de posicionamento relativo o mesmo é praticamente eliminado (MONICO, 2000). 


\subsection{TECTÔNICA DE Placas LitosfÉRICAS}

A fim de se manter a estabilidade de um sistema de coordenadas, as coordenadas de um conjunto de estações devem ser estabelecidas para uma dada época e serem atualizadas devido ao movimento das placas litosféricas. Uma maneira de controlar os movimentos horizontais é estimar parâmetros de velocidade para as estações (INSTITUTO GEOGRÁFICO NACIONAL, 2006).

Através de uma rede de estações de monitoramento contínuo distribuídas sobre a área de interesse, as variações em posição do local podem ser monitoradas ao longo do tempo, e o movimento tectônico pode ser estimado com o auxílio de várias tecnologias geodésicas espaciais (SLR, VLBI, GPS).

Geralmente os movimentos das placas são lentos e pouco perceptíveis, com exceção das regiões onde a ocorrência de terremotos é elevada. Nestas regiões, deslocamentos significativos em um período de tempo muito curto podem ocorrer, criando-se a necessidade de um monitoramento sistemático (CRUSTAL DYNAMICS DATA INFORMATION SYSTEM, 2006).

\subsection{EFEITOS DA MARÉ}

Fenômenos de marés são outra fonte de deslocamento permanente das estações, e são modelados conforme as convenções do IERS. A maioria dos programas comerciais não leva em conta estes efeitos, que são anulados com a utilização de linhas de base relativamente curtas empregando-se o método relativo. Em valor absoluto este efeito pode chegar a ser de até $40 \mathrm{~cm}$, e em aplicações rigorosas e em cálculos de redes globais, deve ser introduzido um modelo de correção (INSTITUTO GEOGRÁFICO NACIONAL, 2006).

As marés são causadas pela variação temporal da atração gravitacional do Sol e da Lua devido ao movimento orbital, e podem ser divididas em:

- Marés oceânicas: são muito mais fáceis de serem modeladas em regiões litorâneas e em suas imediações, podendo ser corrigida através 
de modelos específicos. Sua periodicidade pode ser modelada a partir do movimento dos corpos celestes (INSTITUTO GEOGRÁFICO NACIONAL, 2006).

- Marés terrestres: geram deslocamentos periódicos nas estações, que varia em função do tempo e da posição da estação, podendo chegar a até $40 \mathrm{~cm}$ na componente vertical e $5 \mathrm{~cm}$ na horizontal (MONICO, 2000). Mais informações sobre marés podem ser encontradas em Mccarthy, 1992.

\subsection{CARGA OCEÂNICA}

Denomina-se carga oceânica a deformação do solo do mar e do solo costeiro como conseqüência da redistribuição da água do mar que ocorre durante a maré oceânica. A crosta terrestre se deforma devido ao peso da água (INSTITUTO GEOGRÁFICO NACIONAL, 2006).

A magnitude do deslocamento é função das características da crosta e das posições do Sol, da Lua e da estação, podendo chegar a até $10 \mathrm{~cm}$ na componente vertical em regiões costeiras. Em regiões afastadas da costa esse valor é menor, podendo alcançar cerca de $1 \mathrm{~cm}$ para uma distância oceano-estação de $1000 \mathrm{~km}$. Em levantamentos de alta precisão tal efeito deve ser considerado, mas, na maioria das aplicações práticas este efeito pode ser desprezado (MONICO, 2000).

\subsection{CARGA ATMOSFÉRICA}

Variações da distribuição da massa atmosférica induzem a deformações na crosta, principalmente na direção vertical. As maiores deformações estão associadas com tempestades (synoptic storms) na atmosfera, podendo alcançar $1 \mathrm{~cm}$. A maioria dos programas de processamento GPS não apresenta modelos de correção para este efeito, pois, este não é um efeito com o qual o usuário deva se preocupar, mas 
vale a pena saber que o mesmo afeta as coordenadas determinadas por GPS (MONICO, 2000).

\subsubsection{ERROS RELACIONADOS COM O RECEPTOR E A ANTENA}

Os erros aqui descritos são aqueles ocasionados por problemas no hardware do receptor/antena e pela manipulação errada da antena, além da anotação equivocada de sua altura.

\subsection{MEdiçÃo dA Altura da AnTENA}

A medição da altura da antena pode resultar em erro grosseiro, sendo este o que ocorre com maior freqüência durante o levantamento GPS. O grande problema é que este tipo de erro não é detectado no processamento dos dados coletados. A maneira de tentar se evitar este tipo de erro é realizar múltiplas sessões de rastreio fazendo com que cada ponto medido seja reocupado.

Ao se realizar o processamento dos dados GPS é necessário que seja inserido o valor da altura da antena medido em campo, a fim de indicar seu desnível em relação ao marco ocupado. Existem dois tipos de medidas: a inclinada e a vertical. A inclinada é obtida medindo-se a distância entre o ponto a ser posicionado e a borda da antena. A vertical é a distância medida entre o marco ocupado e o Antenna Reference Point (ARP), situado na rosca da base da antena (SANTOS, 2005). Existe ainda a medida conhecida como true vertical, que é a altura medida entre o marco ocupado e a antena, já corrigido do valor referente ao centro de fase da antena.

Quando é utilizado um pilar, com pino de centragem forçada, em que o ARP da antena fique rente à cabeça do pilar, caso da estação NEIA, considera-se que sua altura é zero, evitando-se assim o erro na medição da mesma. 


\subsection{ERRO do RELógIo do RECEPTOR (DERIVA do RELóGIO)}

A grande maioria dos receptores GPS possui osciladores de quartzo, que proporcionam boa estabilidade a um custo relativamente baixo (MONICO, 2000). No entanto, são muito sensíveis a variações de temperatura, efeito este que, acelera seu processo de envelhecimento (SILVA, 2005).

No posicionamento absoluto, o erro do relógio do receptor aparece como incógnita nas equações de observação do modelo. O erro do relógio neste tipo de levantamento deve ser estimado, pois um erro da ordem de $1 \mathrm{~ms}$ provoca um erro na medida da distância entre o satélite e o receptor da ordem de $300 \mathrm{~m}$. Por isso existe a necessidade de observação de, pelo menos, 4 satélites simultaneamente possibilitando a determinação da deriva do relógio do receptor (FAZAN, 2002).

Já no posicionamento relativo, desde que haja simultaneidade nas observações, esse erro é praticamente eliminado, não exigindo padrões de tempo altamente estáveis (GREWAL et al. 2001 apud SILVA, 2005).

\subsubsection{MODERNIZAÇÃO DO GPS}

Após vários anos de utilização, o Sistema de Posicionamento Global foi reconhecido como uma grande ferramenta para o futuro da navegação, seja para aplicações militares ou civis. A aviação civil foi um dos principais beneficiários do GPS, favorecida pela abrangência global do sistema. Em 1999, em razão dos resultados benéficos trazidos à comunidade civil, o vice-presidente americano, Al Gore, anunciou que os Estados Unidos estavam iniciando os planos de modernização do GPS a fim de estender suas potencialidades além daquelas propiciadas pela constelação existente até aquele momento.

As novas diretrizes mostram a intenção do governo dos Estados Unidos em manter o serviço básico do Sistema de Posicionamento Global de forma contínua e gratuita a todos os usuários civis, desde que seja utilizada para fins pacíficos. $O$ governo norte-americano entende que o GPS tornou-se um instrumento de utilização 
global, sendo de grande importância não só para assuntos de segurança nacional, mas também para vários setores da economia mundial.

A modernização do GPS vem ocorrendo em seus dois principais segmentos: no de controle e no espacial, o que gera elevados custos de implementação.

Um dos principais componentes desta modernização é a adição de um novo código para o uso civil e uma nova portadora. O primeiro destes novos sinais é um código civil, nomeado L2C, que foi adicionado à portadora L2 existente, situado em 1227,60 MHz. O primeiro satélite atualizado do bloco IIR, designado de IIR-M (modernizado), lançado em 25 de setembro de 2005 (FEDERAL AVIATION ADMINISTRATION, 2006) é o primeiro da era modernizada do GPS, de um total de oito previstos, e está ativo desde 16 de dezembro do mesmo ano.

Os benefícios do novo sinal poderão ser sentidos pelos usuários assim que o novo satélite entrar em operação, não sendo necessário que toda a constelação transmita a L2C. Além do código em L2, os satélites modernizados transmitirão também dois códigos de uso exclusivo dos militares norte-americanos - L1M em L1 e L2M em L2 (FEDERAL AVIATION ADMINISTRATION, 2006).

Uma terceira portadora denominada L5, situada na freqüência de 1176,45 $\mathrm{MHz}$, será fornecida primeiramente nos satélites do bloco IIF (quarta geração dos satélites do bloco II), previstos para serem lançados a partir de 2007, e continuará sendo implementada nos satélites do bloco III programados para serem lançados a partir de 2012. Esta nova freqüência L5 será protegida mundialmente e destinada para o uso em radionavegação aeronáutica, e propiciará aplicações voltadas para a segurança da aviação. De maior potência que as freqüências existentes, a L5 tornará mais fácil o rastreamento de sinais GPS e possibilitará o processamento utilizando três ondas portadoras. Para que se tenha acesso a seus benefícios, há a necessidade de que toda a constelação transmita sinais nesta freqüência, mas isto ainda está longe de se tornar realidade. Levando-se em consideração a atual taxa de renovação dos satélites GPS, os três sinais civis (L1-C/A, L2-L2C e L5) só estarão disponíveis operacionalmente a partir de 2012, devendo estar em total operação por volta de 2015 (FEDERAL AVIATION ADMINISTRATION, 2006).

Com esta nova concepção colocada em prática, será possível alcançar melhor precisão para as medidas de fase de batimento da onda portadora, resultando em coordenadas mais exatas. 
Para a Geodésia e a Topografia a terceira portadora será importante na resolução das ambigüidades, pois a mesma será facilitada, tendo em vista que será possível realizar mais combinações lineares, isto é, somar ou subtrair observações de fase em duas freqüências. Na Tabela 2.1 são mostradas algumas das combinações resultantes. Pode-se observar que a combinação wide-lane (L2-L5) resulta em uma freqüência de comprimento de onda maior que as freqüências $L 1$ e L2. Esta característica é muito importante, pois, geralmente, quanto maior o comprimento de onda, mais rápida será a resolução das ambigüidades (SANTOS, 2000).

Tabela 2.1 - Características e combinações dos sinais GPS

\begin{tabular}{ccc}
\hline Sinal & Freqüência (MHz) & $\begin{array}{c}\text { Comprimento de onda } \\
(\mathbf{c m})\end{array}$ \\
\hline Portadora L1 & 1575,42 & 19,03 \\
Portadora L2 & 1227,60 & 24,42 \\
Portadora L5 & 1176,45 & 25,48 \\
Wide-Lane (L1-L2) & 347,83 & 86,19 \\
Narrow-Lane (L1+L2) & 2803,02 & 10,70 \\
L1-L5 & 398,97 & 75,14 \\
L2-L5 & 51,15 & 586,10 \\
\hline
\end{tabular}

Fonte: Santos, 2000

Com a modernização do GPS, a qualidade do posicionamento melhorará gradualmente nos anos subseqüentes. Desde o início do GPS, podem-se distinguir para navegação, as seguintes exatidões (BRUYNINX, 2002):

- 20 - 100 m: utilizando código C/A com SA ativa (antes de maio de 2000);

- 10 - 20 m: atualmente, utilizando código C/A com SA desativada;

- 5 - 10 m: a partir de 2009, utilizando os códigos C/A e L2C;

- 1 - 5 m: a partir de 2013, utilizando o código C/A, o código L2C e o novo código modulado na portadora L5. 


\subsubsection{MÉTOdOS DE RESOLUÇÃo DA AMBIGÜIDADE}

Nos últimos anos, foram intensificados os esforços para tentar se resolver as ambigüidades da fase da onda portadora do GPS. Desde a primeira demonstração de uso das observações da fase da onda portadora do GPS para posicionamento sub-centimétrico até o desenvolvimento das técnicas on-the-fly (OTF) de resolução instantânea da ambigüidade, vários métodos foram propostos por diversas instituições distribuídas pelo mundo inteiro, tendo-se sempre buscado solucionar as ambigüidades para o posicionamento relativo cinemático (KIM e LANGLEY, 2000).

Em vista disso, grande atenção vem sendo dada à solução rápida das ambigüidades, cujo modelo matemático funcional tem como observações básicas as duplas diferenças (DD) da fase de batimento da onda portadora e da pseudodistância (MACHADO e MONICO, 1999). A pesquisa nesta área tendeu a aumentar devido ao número extensivo de aplicações científicas que podem se beneficiar com o posicionamento de alta precisão além de, também, existir grande interesse comercial na resolução deste problema (KIM e LANGLEY, 2000).

A ambigüidade da onda portadora do GPS representa um contador arbitrário do ciclo da mesma, que registra o início das observações de um satélite em uma seqüência inteira, sem interrupções, de observações da onda por ele emitida. Uma vez que as ambigüidades inteiras são fixadas corretamente, as observações da fase da onda portadora, conceitualmente, estão convergindo para medidas de distância de alta acurácia atingindo a escala milimétrica, e a partir daí, é possível alcançar o nível centimétrico na solução do posicionamento. Entretanto, fixar as ambigüidades inteiras é um problema complicado, especialmente se visarmos a eficiência e o elevado desempenho computacionais envolvidos, devido a isso, este assunto tem sido uma rica fonte para as pesquisas em GPS nos últimos tempos (KIM e LANGLEY, 2000).

Segundo Kim e Langley, 2000, os métodos de solução da ambigüidade podem ser classificados em:

- Métodos de solução no domínio das observações: são as técnicas mais simples de resolução da ambigüidade. Utilizam os códigos C/A ou $P$ para determinar as ambigüidades correspondentes às observações da 
fase. Geralmente, não é um método muito bom para determinação das ambigüidades inteiras, pois, não possibilita as combinações lineares entre as fases das ondas portadoras L1 e L2, que podem ser utilizadas como um filtro para as ambigüidades estimadas. Mais detalhes podem ser encontrados em Collins, 1999;

- Método de procura no domínio das coordenadas: esta técnica utiliza apenas o valor fracionário da medida instantânea da fase da onda portadora, sendo que, os valores da função da ambigüidade não são afetados pela mudança do número inteiro de ciclos da fase da onda portadora e nem devido à perda de ciclos. Apesar de o algoritmo original ter sido melhorado por Han e Rizos, 1996, a técnica fornece uma eficiência computacional muito baixa;

- Método de procura no domínio das ambigüidades: esta classe compreende a maioria dos modelos desenvolvidos, baseados no Método dos Mínimos Quadrados (MMQ). A estimação do parâmetro, teoricamente, é realizado em três etapas: a solução flutuante (Float), a estimação das ambigüidades inteiras, e a solução fixa (Fixed). Estas técnicas empregam a matriz de variância-covariância (MVC) obtida na etapa da solução flutuante na fase de estimação das ambigüidades inteiras, ajustando-as até chegar a uma solução fixa.

Outra proposta de classificação dos métodos de solução das ambigüidades pode ser encontrada em (HAN e RIZOS, 1997 apud MACHADO, 2002).

Entre os métodos de solução existentes pode-se citar: Método da troca de antena, proposto por Remondi; Método de Euler/Landau, Método FARA (Fast Ambiguity Resolution Approach), proposto por Frei; método LAMBDA (Least squares AMBiguity Decorrelation Approach), proposto por Teunissen (MONICO, 1996), Método FASF (Fast Ambiguity Search Filter) proposto por Chen \& Lachapelle em 1996 e o Whitining Filtering, proposto por Mohamed em 1998. A maioria desses métodos utiliza a solução pelo MMQ com algoritmo de procura (MACHADO, 2002).

A Figura 10 mostra o fluxograma da utilização das DD de fase da onda portadora para o posicionamento GPS. Em geral, há três procedimentos envolvidos: [1] o procedimento do filtro float, [2a] a definição da ambigüidade e [2b] o 
procedimento de validação, e o procedimento [3] que é a geração da solução fixa (LIU, 2003), sendo $(\check{\boldsymbol{N}})$ a solução float das DD de ambigüidades e $\left(\boldsymbol{C}_{\check{N}}\right)$ a sua MVC.

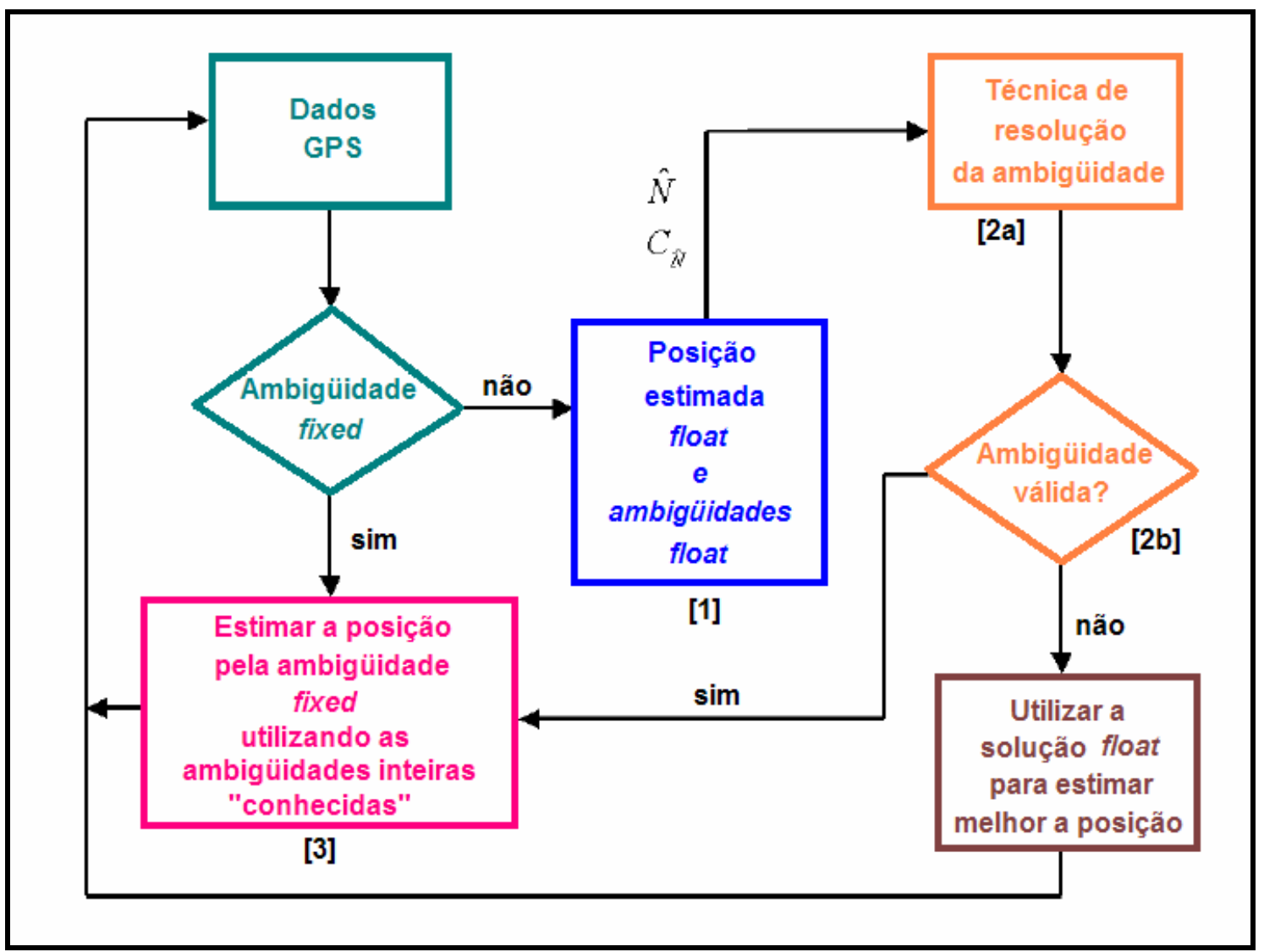

Figura 10: Fluxograma da utilização das DD de fase da onda portadora na resolução das ambigüidades.

Fonte: Liu, 2003

A seguir, são apresentados alguns métodos de solução da ambigüidade GPS existentes.

\subsubsection{MÉTODO SEQÜENCIAL}

Este método, proposto por Talbot, utiliza o Filtro de Kalman para a estimação das DD de ambigüidade e de sua respectiva MVC (MACHADO, 2002), e classificase como um método de procura no espaço das ambigüidades (KIM e LANGLEY, 2000). 
Utilizando-se a MVC, as DD de ambigüidade são testadas e avaliadas a cada época, e caso alguma possa ser fixada como inteira, ela é inserida como injunção no ajustamento. O processamento continua até que todas as DD de ambigüidades sejam solucionadas, e devido à forte correlação entre as ambigüidades, a solução de uma delas contribui positivamente para a solução das demais (MACHADO, 2002).

Esse método não se enquadra como um método de solução rápida, pois, requer que a geometria dos satélites se altere, mas, pode ser utilizado para calcular a MVC das DD de ambigüidades para serem utilizadas como entrada em outros métodos (MACHADO, 2002).

\subsubsection{MÉTODO DA TROCA DE ANTENA}

Proposto por Remondi, consiste na instalação de dois receptores (1 e 2) em duas estações ( $\mathrm{i}$ e j) distintas, que podem estar separadas de 2 a $5 \mathrm{~m}$. É necessário que uma das duas estações tenha coordenadas conhecidas. Para aplicação do método, deve-se coletar dados por aproximadamente um minuto, e sem perder o contato com os satélites, trocar as antenas de posição, ou seja, a antena que estava ocupando a estação i passa a ocupar a estação j e vice-versa, e por fim coletar dados por mais um minuto (MONICO, 1996).

Neste método, ao invés de se esperar a mudança da geometria dos satélites, altera-se a geometria das antenas, mas, caso ocorra perda de ciclos, deve-se repetir o processo.

\subsubsection{COMBINAÇÕES LINEARES ENTRE AS PORTADORAS}

Algumas combinações lineares entre as fases das ondas portadoras L1 e L2 apresentam importante papel no que diz respeito à solução das ambigüidades. Geralmente, procura-se por combinações que produzam comprimentos de onda 
maiores e baixos níveis de ruídos, sendo este, o caso da combinação linear wide lane, com aproximadamente 86,2 cm de comprimento de onda (TALBOT, 1991 apud MACHADO, 2002). Essa técnica se enquadra na técnica de solução da ambigüidade no domínio da observação (KIM e LANGLEY, 2000).

Para obter melhor precisão, tanto das componentes da linha de base, quanto das DD de ambigüidades, é necessário que outras combinações, como a L0 (ou L3) (Ionospheric Free), sejam utilizadas sequencialmente no processo (TALBOT, 1991 apud MACHADO, 2002).

Com a implantação da terceira freqüência civil (L5), prevista no processo de modernização do GPS, será possível aplicar uma combinação linear com comprimento de onda de $5,86 \mathrm{~m}$, o que será benéfico para a resolução de ambigüidades (SANTOS, 2000).

\subsubsection{MÉTODO DE EULER/LANDAU}

Proposto por Euller e Landau em 1992 está baseado no MMQ com algoritmo de procura, e segundo Kim e Langley, 2000, se enquadra nas técnicas de busca no domínio da ambigüidade. Entretanto, devido ao esforço computacional necessário, que inviabilizaria a aplicação prática, pois não proporcionaria uma solução rápida, aplica-se a decomposição de Cholesky, na MVC das DD de ambigüidades (MACHADO, 2002). A decomposição pode ser vista em Monico, 1996.

A cada novo elemento calculado, um valor parcial $\left(\chi^{2}\right)$ também pode ser calculado, o qual é testado contra um valor pré-estabelecido. Em caso de rejeição, o cálculo de $\left(\chi^{2}\right)$ é interrompido e outro valor de ambigüidade é testado. No caso de mais de um vetor ser aceito em uma determinada época, a procura continua na próxima época, e somente, os vetores aceitos são utilizados (MONICO, 1996). 
O método FARA foi proposto por Frei em 1992 e consiste na utilização do MMQ com algoritmo de procura, se enquadrando nas técnicas de busca no domínio das ambigüidades (KIM e LANGLEY, 2000). Intervalos de confiança são utilizados para comparações, ou seja, um intervalo para cada DD de ambigüidade "possível" e entre suas diferenças é criado (MONICO, 1996).

O resultado da procura fornece uma lista de possíveis conjuntos de ambigüidades, os quais são introduzidos no ajustamento como injunções, e o vetor que apresentar menor variância a posteriori é selecionado para a solução final (MACHADO, 2002).

\subsubsection{MÉTODO LAMBDA}

O método LAMBDA, proposto em 1993 por P.J.G. Teunissen, da Universidade de Tecnologia de Delft, na Holanda, utiliza o MMQ associado com algoritmo de procura, sendo que, este método também se enquadra nas técnicas de busca no domínio das ambigüidades (KIM e LANGLEY, 2000).

Suas principais características são a estimação seqüencial através do $M M Q$, precedido pela decorrelação das ambigüidades. A novidade em relação aos outros métodos é a reparametrização da decorrelação das ambigüidades, que através do MMQ pode estimar o valor inteiro da ambigüidade, sendo computacionalmente rápido e eficiente. Para navegação precisa ou em levantamentos utilizando o GPS, pode-se atingir a resolução da ambigüidade com alto grau de confiança, utilizando dados de um pequeno intervalo de tempo. A resolução é possível instantaneamente, sendo realmente OTF (DELFT UNIVERSITY OF TECHNOLOGY, 2007).

Assumindo-se um vetor de ambigüidades n-dimensional, o método LAMBDA pode ser resumido ao seguinte princípio (LIU, 2003): 


$$
(\tilde{\mathrm{N}}-\mathrm{N}) \mathrm{C}_{\tilde{\mathrm{N}}}^{-1}(\tilde{\mathrm{N}}-\mathrm{N})^{\mathrm{T}}=\text { mínimo }, \text { com } \mathrm{N} \in \mathrm{Z}^{\mathrm{n}}
$$

onde:

N - solução float das DD de ambigüidades;

$\mathrm{N}$ - vetor dos parâmetros referentes às DD de ambigüidades;

$\mathrm{C}_{\tilde{\mathrm{N}}}-\mathrm{MVC}$ da solução float;

$\mathrm{Z}^{\mathrm{n}}$ - espaço inteiro n-dimensional.

Mais detalhes sobre este método e sua formulação matemática podem ser vistos em Machado, 2002 e Delft University of Technology, 2007.

Uma variação do método LAMBDA é o método MLAMBDA (Modified LAMBDA), que tem como objetivo reduzir a complexidade computacional do método LAMBDA e pode ser visto em, Chang, Yang e Zhou, 2005.

\subsubsection{VALIDAÇÃO}

Antes de aceitar a solução gerada por um dos métodos descritos, é recomendável verificar a qualidade desses parâmetros através do processo de validação da solução da ambigüidade (TEUNISSEN, 1998b apud MACHADO, 2002).

A fase de validação da solução da ambigüidade pode ser dividida em duas etapas (WANG, 1999 apud MACHADO, 2002):

- Teste de aceitação: visa verificar a compatibilidade entre cada vetor que satisfaz a área de procura com as observações GPS;

- Teste de discriminação: objetiva comparar o quanto o vetor que produz a melhor solução difere da segunda melhor.

A validação da solução das ambigüidades está envolvida com testes estatísticos, sendo que, três hipóteses podem ser postuladas (TEUNISSEN, 1998b apud MACHADO, 2002):

- $\mathrm{H}_{1}$ : representa o modelo de observação sem injunção, cuja solução pelo MMQ proporciona a solução float; 
- $\mathrm{H}_{2}$ : é mais relaxada e não impõem nenhuma restrição ao modelo;

- $\mathrm{H}_{3}$ : representa o modelo de observação com injunção, cuja solução pelo MMQ é a fixed.

$\mathrm{O}$ teste de validação é realizado através da validação da $\mathrm{H} 3$, a qual pode ser efetuada comparando-a contra $\mathrm{H} 1$ ou $\mathrm{H} 2$. Porém, se $\mathrm{H} 3$ for comparada contra $\mathrm{H} 1$, a validação torna-se mais confiável (MACHADO, 2002).

A validação não garante que apenas um vetor passará no teste, sendo assim, é necessário realizar o teste de discriminação entre os vetores não rejeitados. $O$ teste de discriminação permite verificar o quanto o vetor que produz a menor unidade de variância a posteriori ( $\left.\check{n}_{1}\right)$ difere do vetor que produz a segunda menor $\left(\check{n}_{2}\right)$. Um dos testes de discriminação mais conhecido e utilizado é o teste ratio, o qual consiste em se calcular a razão entre a unidade de variância a posteriori de $\check{n}_{2}$ e $\check{n}_{1}$, sendo (TEUNISSEN, 1998b apud MACHADO, 2002):

$$
\Omega_{2} / \Omega_{1}>\mathrm{e}_{\mathrm{r}}
$$

onde:

$\Omega_{1}$ e $\Omega_{2}$ - representam a forma quadrática para ň $\check{n}_{1}$. $\check{n}_{2}$;

$e_{r}$ - valor crítico $\left(e_{r}>1\right)$ que é definido empiricamente.

Outro teste de discriminação proposto é dado pela diferença entre $\Omega_{1}$ e $\Omega_{2}$ (TIBERIUS \& DE JONGE, 1995 apud MACHADO, 2002):

$$
\Delta \Omega=\Omega_{2}-\Omega_{1}>\mathrm{e}_{\Delta}
$$

onde:

$e_{\Delta}$ é o valor crítico (recomendado $e_{\Delta}=15$ ), definido empiricamente.

A discriminação entre as ambigüidades é assumida suficiente quando a distância entre ň2 e ň for suficientemente maior que a distância entre $\check{n}_{1}$ e ň (TIBERIUS \& DE JONGE, 1995 apud MACHADO, 2002). 
Em síntese, a estimação rápida dos valores de ambigüidade é de fundamental importância para levantamentos em que seja necessário atingir uma maior acurácia. Solucionar rapidamente as ambigüidades acarreta como conseqüência o aumento da produtividade, uma vez que, o tempo de rastreio pode ser bastante reduzido (MACHADO, 2002).

\subsection{GLONASS}

O sistema russo GLONASS - GLObal'naya NAvigatsionnay Sputnikovaya Sistema, que pode ser traduzido como "Sistema Global de Posicionamento por Satélite", é baseado em uma constelação de satélites ativos que transmitem continuamente sinais codificados em duas faixas de freqüência, que podem ser recebidos por usuários em qualquer lugar da superfície da Terra, para determinar a sua posição em tempo real. O sistema utiliza basicamente os mesmos princípios de transmissão de dados e de métodos de posicionamento do GPS.

O GLONASS disponibiliza dois tipos de sinal de navegação: o sinal padrão de precisão para navegação SP (Standard Precision) e o sinal de alta precisão para navegação HP (High Precision). Os serviços de posicionamento SP estão disponíveis a todos os usuários civis do GLONASS (COORDINATIONAL SCIENTIFIC INFORMATION CENTER, 2006). Os sinais de navegação estão situados na Faixa L em 25 canais separados por intervalos de 0,5625 MHz em 2 faixas de freqüência: 1602,5625 - 1615,5 MHz e 1240 - $1260 \mathrm{MHz}$, isto significa que, cada satélite transmite o sinal em sua própria freqüência. Entretanto, alguns satélites possuem a mesma freqüência, mas como são colocados em posições antípodas nos planos orbitais, não ficam disponíveis ao mesmo tempo para um mesmo usuário (ASTRONAUTIX, 2006).

Os primeiros satélites GLONASS foram colocados em órbita em 1982. Os planos originais apontavam para que o sistema estivesse em total operação por volta de 1991, mas, o sistema foi declarado oficialmente operacional apenas no dia 24 de setembro de 1993, por meio de decreto do então presidente da Federação Russa, sendo que, a constelação não foi completada antes do final de 1995 e início do ano 
seguinte. O sistema foi projetado para ser composto por 24 satélites, sendo 21 operacionais e 3 sobressalentes, distribuídos em três planos orbitais inclinados $64,8^{\circ}$ em relação ao plano do equador, e orbitarem a uma altitude aproximada de $19.100 \mathrm{~km}$, com um período de revolução de 11 horas e 15 minutos (POLISCHUK et al., 2002).

Entre 1996 e 1998, devido à falta de financiamento, a constelação do GLONASS não foi mantida. Em conseqüência, o número de satélites operacionais declinou significativamente.

A constelação está operando atualmente de modo degradado, mas, um programa para a reestruturação gradual da constelação do GLONASS está em andamento. O novo projeto denominado GLONASS-M, será dotado de novos e modernos satélites com melhores características de sinal, além de uma vida útil mais longa (entre 7 a 8 anos em vez dos atuais 3 anos).

No dia 25 de dezembro de 2005 foi iniciada a era de modernização do sistema, com o lançamento simultâneo de três satélites GLONASS-M. Dando continuidade ao plano de modernização, no dia 25 de dezembro de 2006, outros três satélites modernizados foram lançados mas, ainda, não encontram-se em operação pois estão em fase de testes e validação (INTERNATIONAL GNSS SERVICE, 2006). De acordo com Sergei Ivanov, ministro da defesa russo, no futuro, os planos apontam para a transição dos satélites atuais, para uma terceira geração de satélites de menor massa, chamados de GLONASS-K, com uma vida útil de aproximadamente 10 anos (MUNDOGEO, 2006).

\subsection{GALILEO}

O GALILEO é o projeto de navegação por satélite desenvolvido conjuntamente pela União Européia (UE) e pela European Space Agency (ESA), que visa fornecer um serviço de posicionamento global para a sociedade civil. O projeto, iniciado em 2002, está planejado para estar totalmente operacional em 2010 (ENCYCLOPEDIA OF ASTROBIOLOGY ASTRONOMY AND SPACEFLIGHT, 2006). 
Diferentemente do GPS e do GLONASS, o GALILEO não será controlado por militares, evitando que o sistema seja desligado a qualquer momento a fim de satisfazer objetivos estritamente bélicos. Em contrapartida, por ser um projeto comercial, o GALILEO cobrará por seus serviços e não será gratuito como os outros dois sistemas. Apesar disso, os três sistemas de navegação poderão operar conjuntamente, proporcionando ao usuário uma superabundância de satélites. Essa interação entre os 3 sistemas permitirá total cobertura sobre a superfície terrestre. Os satélites GALILEO possuirão órbitas um pouco mais inclinadas $\left(56^{\circ}\right)$ em relação ao plano equatorial do que o GPS, possibilitando uma boa cobertura a até $75^{\circ}$ de latitude (EUROPEAN SPACE AGENCY, 2006).

O GALILEO será um aperfeiçoamento do sistema EGNOS, que foi criado à partir de uma parceria entre a ESA, a Comissão Européia e a Organização Européia para a Segurança da Navegação Aérea e foi o primeiro aporte europeu ao GNSS. O sistema EGNOS consiste em três satélites geoestacionários e em uma rede de estações terrestres que transmitem um sinal que contém informações da confiabilidade e exatidão dos sinais emitidos pelos sistemas GPS e GLONASS. Com isto, permite aos usuários situados na Europa determinar sua posição, utilizando receptor de navegação dotado de dispositivo para recepção dos sinais de correção, com um erro aproximado de $5 \mathrm{~m}$ comparados aos aproximadamente $15 \mathrm{~m}$ sem a utilização do serviço (EUROPEAN SPACE AGENCY, 2006).

O primeiro satélite experimental do GALILEO, chamado de GIOVE-A (Galileo In-Orbit Validation Element-A), foi lançado em 28 de dezembro de 2005, chegando a sua órbita programada de $23.260 \mathrm{~km}$ de altura, tendo transmitido seus primeiros sinais a partir de 12 de janeiro de 2006. Um segundo satélite, chamado de GIOVE-B, está programado para ser lançado ao final de 2007. As principais funções destes satélites experimentais são testar algumas tecnologias que estão sendo desenvolvidas pela ESA e ajustar as freqüências dos sinais dos satélites. Uma vez finalizada esta fase de validação, os satélites restantes serão lançados a fim de que - GALILEO alcance a sua operacionalidade completa dentro do prazo previsto, ou seja, até o ano de 2010 (EUROPEAN SPACE AGENCY, 2006).

O sistema, quando inteiramente operacional, contará com 30 satélites (27 ativos e 3 sobressalentes) posicionados em três planos orbitais e a uma altura de 23.222 km. O grande número de satélites aliado a otimização da constelação, e a 
disponibilidade dos três satélites de reposição, garantirá que a perda de um satélite não acarrete problemas aos usuários (EUROPEAN SPACE AGENCY, 2006).

Dois centros de controle, denominados Galileo Control Centers (GCC), situados no continente europeu, serão responsáveis pelo controle dos satélites. Os dados serão fornecidos por uma rede global de vinte estações de monitoramento (Galileo Sensor Stations - GSS), e transmitidos aos GCC's através de uma rede de comunicação. Os GCC's utilizarão os dados das estações monitoras com o intuito de verificar a integridade dos dados e sincronizar o sinal de tempo dos satélites e da estação na Terra (EUROPEAN SPACE AGENCY, 2006).

A maior novidade proporcionada pelo novo sistema é que, cada satélite do GALILEO possuirá um transponder ${ }^{3}$ capaz de receber sinais de socorro dos transmissores dos usuários. Ao receber um sinal de emergência na Terra, o satélite alertará um centro de coordenação de salvamento, que começará a operação de busca. Ao mesmo tempo, o satélite também transmitirá um sinal de retorno ao usuário, avisando que seu alerta foi retransmitido e que, a ajuda está a caminho. Esta característica de interação direta com o usuário é nova, e é considerada a principal melhoria comparada aos sistemas existentes, pois os mesmos não fornecem um relatório ao usuário (EUROPEAN SPACE AGENCY, 2006).

\footnotetext{
${ }^{3}$ dispositivo de comunicação eletrônico cujo objetivo é receber, amplificar e retransmitir um sinal em uma freqüência diferente ou, transmitir de uma fonte uma mensagem pré-determinada em resposta à outra mensagem pré-definida advinda de outra fonte (WIKIPÉDIA, 2006).
} 


\section{MATERIAIS E MÉTODOS}

A seguir são descritos a fonte e o formato dos dados, além dos programas utilizados para a realização desta pesquisa.

\subsection{DADOS UTILIZADOS}

Os dados utilizados nesta pesquisa são da estação GPS ativa NEIA, pertencente à RBMC, localizada na base "Dr. João Paiva de Carvalho" do Instituto Oceanográfico da USP, na cidade de Cananéia/SP.

A estação GPS NEIA é mantida por um convênio entre a EP-USP e o IO-USP e tem seus dados disponibilizados através do sítio do IBGE (http://www.ibge.gov.br/), no link Download, na área de Geociências, acessando a pasta RBMC/DADOS.

A estação está equipada com um receptor GPS da marca Trimble, modelo 4000SSi, que coleta observáveis das duas portadoras ( $L 1$ e L2) e possui uma antena Dorne Margolin equipada com Choke-Ring, modelo TRM29659.00.

Junto à estação existe um computador que é utilizado para o gerenciamento da mesma. Este computador utiliza o sistema operacional LINUX, e através de scripts adotados pela equipe do IO-USP, coleta os dados do receptor, gera os arquivos diários, armazena e também envia os referidos arquivos ao servidor principal.

Devido ao processamento dos dados desta pesquisa ser realizado no modo relativo, foi necessária a utilização de pelo menos uma estação de referência para o cálculo das coordenadas da estação NEIA. A referência escolhida para o processamento foi a estação PARA (ver seção 4.4.1), situada em Curitiba/PR, devido à sua proximidade e integridade dos dados, além de pertencer à RBMC. Os dados utilizados da estação PARA, de 2002 a 2006, foram disponibilizados pela Coordenação de Geodésia do IBGE (CGED/IBGE).

Cabe aqui um pequeno histórico da RBMC, que foi idealizada por Fortes e Godoy (1991) para ser uma rede de rastreamento contínuo durante as 24 horas do dia ao longo de todo o ano. Além de atender às necessidades do próprio IBGE, a 
rede tem como principal característica o suporte aos usuários do Sistema de Posicionamento Global situados no território nacional e em países vizinhos, proporcionando aos mesmos, observações GPS de modo que utilizando apenas um receptor possa realizar o posicionamento relativo, já que o outro se encontra em uma das estações da rede (FONSECA Jr., 2002).

A configuração inicial da RBMC era composta por nove estações que foram implantadas na primeira etapa do projeto além de estações de densificação previstas para uma segunda etapa (FORTES, 1997). Sete estações foram implantadas entre os anos de 1996 e 1997 pelo IBGE, com apoio da EP-USP através de recursos disponibilizados pelo FNMA para a aquisição dos equipamentos, além de duas estações pertencentes à rede IGS. Destas, uma está localizada nas dependências do Instituto de Pesquisas Espaciais (INPE), em Euzébio, no Ceará, instalada no ano de 1993, e outra, implantada no ano de 1995 nas dependências do IBGE, situada na Reserva Ecológica do Roncador, em Brasília, Distrito Federal. (FORTES, 1997)

Atualmente, fevereiro/2007, a RBMC conta com 27 estações, sendo que 24 estão ativas, e outras três encontra-se em fase final de testes. A Figura 11 mostra a distribuição atual das estações da RBMC. 


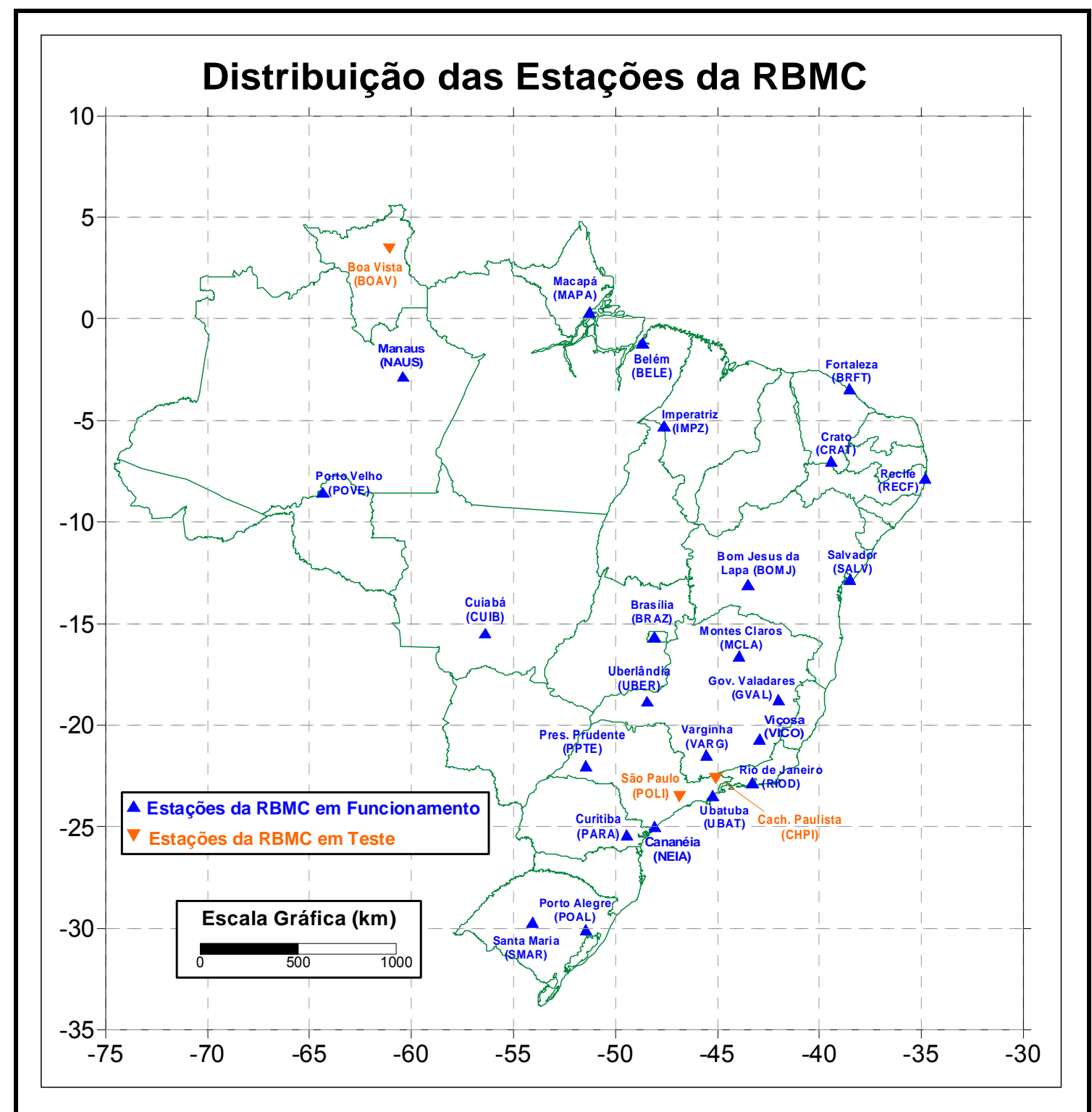

Figura 11: Distribuição atual das estações da RBMC

Fonte: Instituto Brasileiro de Geografia e Estatística, 2006

Cabe ressaltar que todos os locais selecionados para a instalação das estações da RBMC foram escolhidos seguindo as especificações e normas gerais para levantamentos GPS (INSTITUTO BRASILEIRO DE GEOGRAFIA E ESTATÍSTICA, 1993), sendo dada atenção especial para (FORTES, 1997):

- Ausência de obstruções a partir de $10^{\circ}$ acima do horizonte da estação;

- Ausência de superfícies próximas à estação que possam acarretar efeitos de multicaminho;

- Ausência de fontes eletromagnéticas na faixa de freqüência dos sinais GPS (1,2 a 1,6 GHz). 
Além destas condições, outros critérios também foram definidos considerando o caráter permanente das estações, sendo eles (FORTES, 1997):

- Uso de dispositivo de centragem forçada a fim de garantir erros inferiores a $1 \mathrm{~mm}$ quando houver a necessidade de troca e/ou manutenção da antena;

- Estrutura de concreto altamente estável com o intuito de evitar o recalque da mesma;

- Acesso público restrito para evitar a destruição do pilar por vândalos;

- Disponibilidade de uma sala próxima à estação com fornecimento contínuo de energia, assim como acesso via linha telefônica e/ou via rede para transmissão de dados e monitoramento do funcionamento da estação;

- Além de segurança permanente para preservação dos equipamentos.

Vale aqui destacar que na construção e manutenção da estação NEIA (Figuras $12,13,14$ e 15), todos os cuidados citados acima foram tomados no intuito de fornecer dados confiáveis a todos os usuários daquela estação.

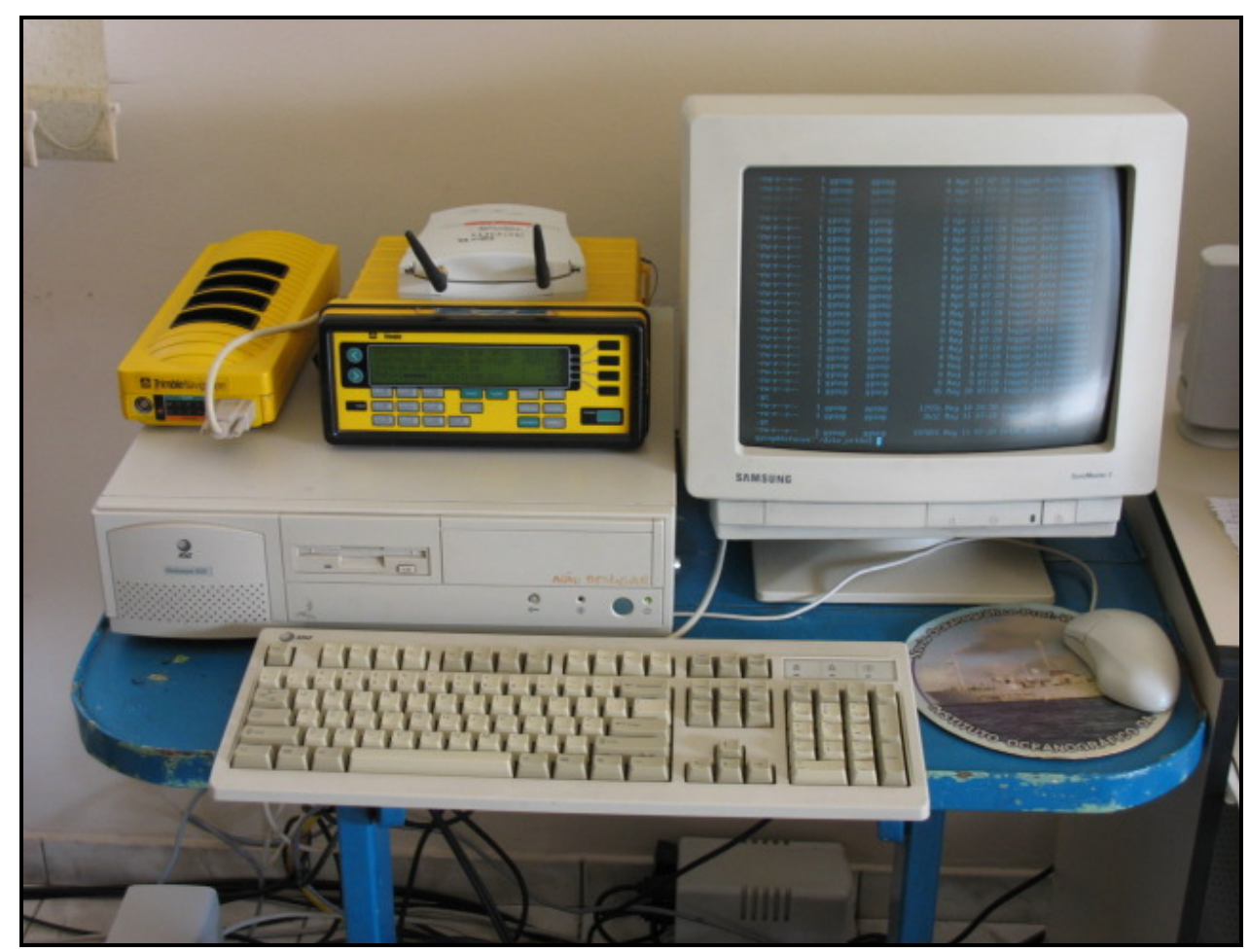

Figura 12: Receptor e computador da estação NEIA

Fonte: Banco de dados do IO-USP 


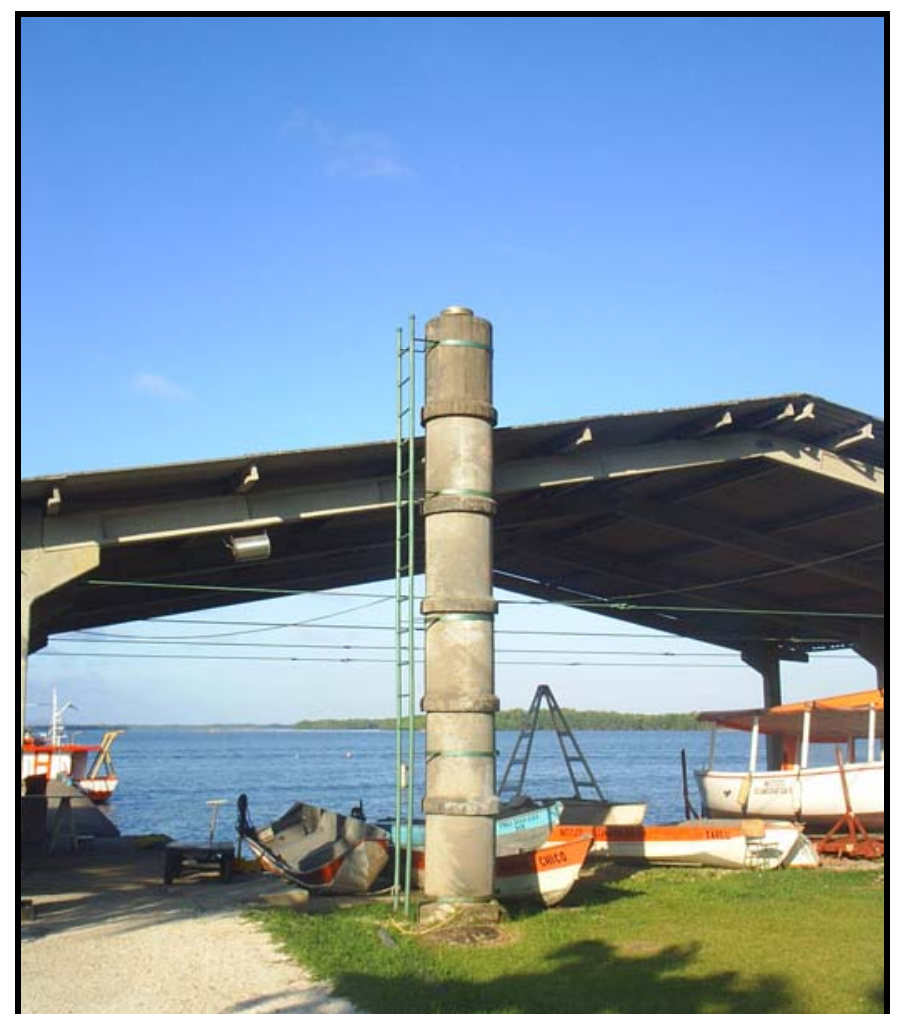

Figura 13: Vista frontal do pilar e antena da estação NEIA Fonte: Banco de dados do IO-USP

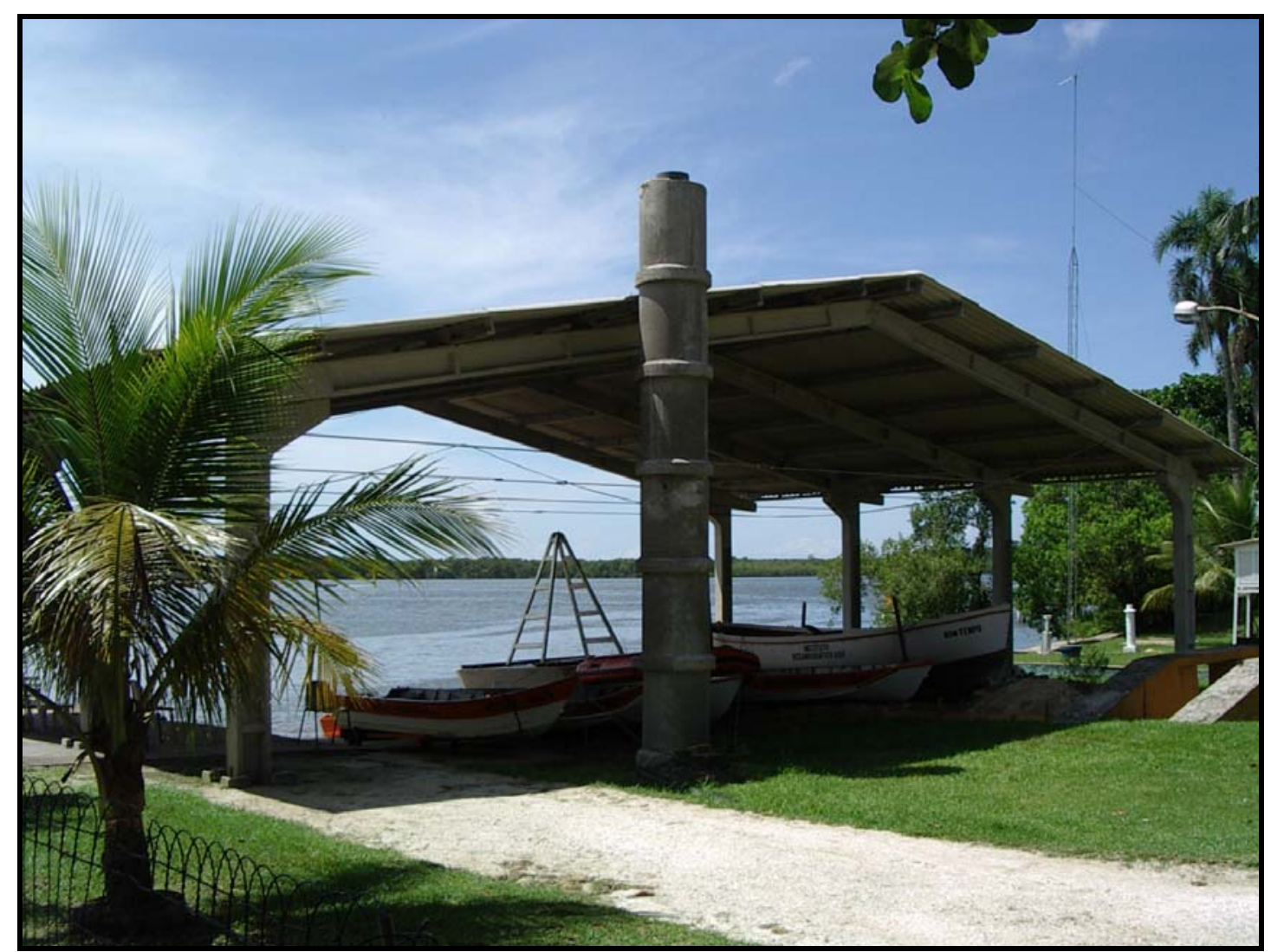

Figura 14: Vista lateral esquerda do pilar e antena da estação NEIA Fonte: Banco de dados do IO-USP 


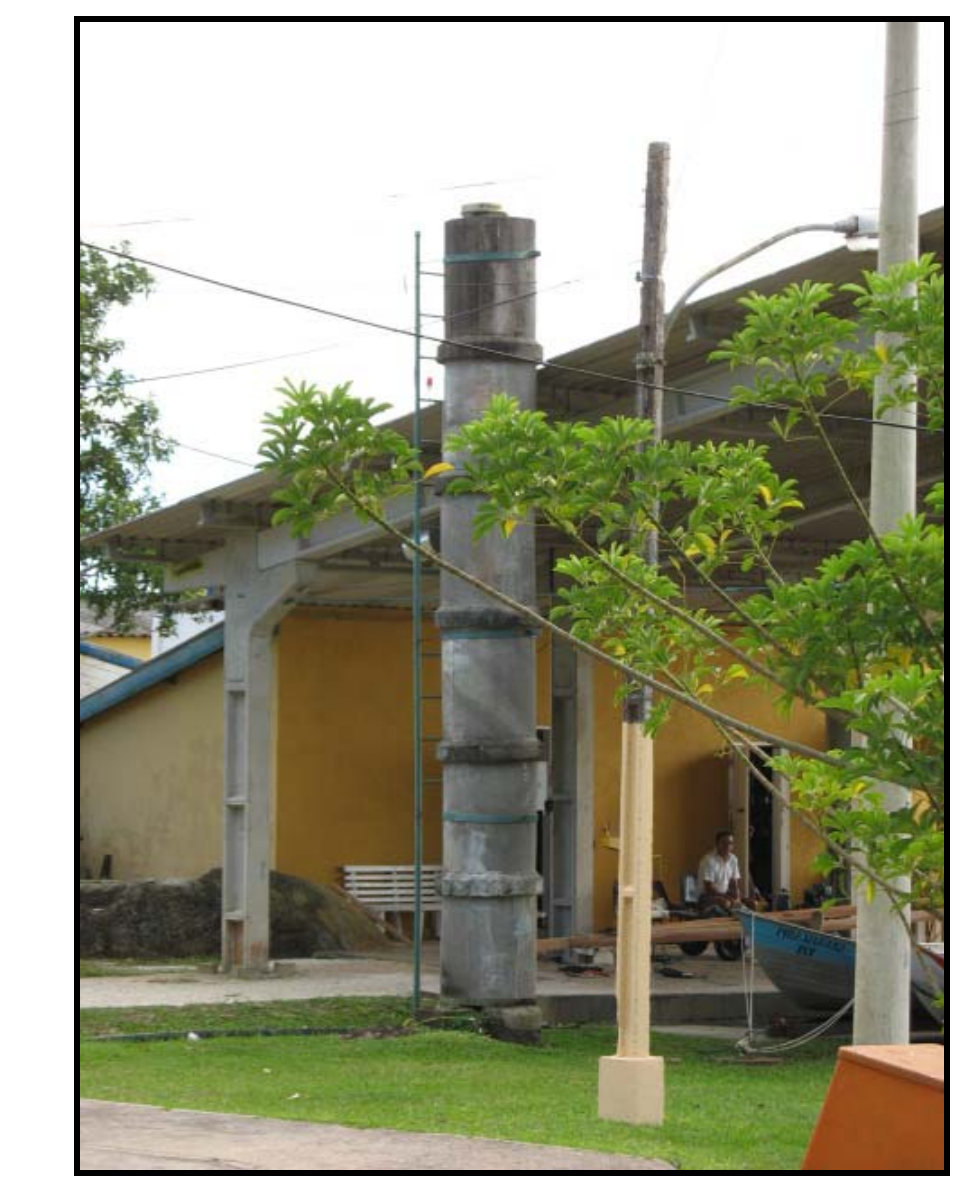

Figura 15: Vista lateral direita do pilar e antena da estação NEIA Fonte: Banco de dados do IO-USP

\subsection{FORMATO DOS DADOS}

Os dados, quando gerados, saem do receptor em formato proprietário e são transformados automaticamente para o formato RINEX (Receiver Independent Exchange Format). Os dados são convertidos para este formato, pois o mesmo pode ser utilizado em qualquer programa de processamento de dados GPS, enquanto o formato proprietário, por ser um formato específico do fabricante, só pode ser utilizado em programas de processamento desenvolvidos pelo mesmo.

Portanto, os dados originais utilizados neste trabalho estão em formato RINEX, possuem 24 horas de observação com taxa de coleta de 15 segundos e máscara de elevação de $10^{\circ}$. 


\subsubsection{TEQC}

O TEQC (Translate, Edit, Quality Check), desenvolvido pela UNAVCO (University NAVSTAR Consortium), é um programa de utilização gratuita. Com ele pode-se trabalhar utilizando dados dos sistemas GPS, GLONASS ou do extinto TRANSIT. Neste trabalho foram utilizados dados coletados apenas pelo sistema GPS. O TEQC permite manipular os dados GPS de várias formas, dentre as quais se destacam:

- Conversão de arquivos GPS em formato binário para o formato RINEX;

- Edição realizada sobre os arquivos RINEX, como: eliminação de uma ou mais observáveis, junção de arquivos consecutivos, divisão do arquivo em intervalos de tempo determinados e;

- Controle de qualidade, onde se pode avaliar a qualidade dos dados coletados através de indicativos calculados pelo programa, como: perdas de ciclos e multicaminho.

O programa TEQC pode ser encontrado no sítio da UNAVCO (http://facility.unavco.org/software/teqc/teqc.html) e está disponível para download gratuitamente. São disponibilizadas versões para as plataformas UNIX, LINUX, MAC e DOS/WINDOWS. No trabalho apresentado foi utilizada a versão para DOS/WINDOWS, de 16/12/2005 compilada utilizando o compilador Borland 5.0.

\subsubsection{CONTROLE DE QUALIDADE UTILIZANDO O TEQC}

Ao realizar o controle de qualidade utilizando O TEQC, o programa gera 7 arquivos de saída com os resultados calculados. Destes, 6 são arquivos gráficos que podem ser visualizados através do programa QCVIEW, e um arquivo ASCII (American Standard Code for Information Interchange) com extensão YYS (sendo 
YY o ano do arquivo analisado) contendo um sumário do controle de qualidade que traz as seguintes informações: tempo total das observações coletadas, máscara de elevação, deriva do relógio do receptor, ângulo de elevação dos satélites, multicaminho em L1 e em L2, perdas de ciclos, além de outras informações. Neste trabalho, os gráficos apresentados para o multicaminho e perdas de ciclos foram construídos com informações extraídas do referido arquivo.

\subsection{FORMULAÇÃo DE MP1 E DE MP2}

Os indicativos MP1 e MP2 quantificam a presença de multicaminho nas portadoras L1 e L2. Nestes indicativos também estão embutidas as incertezas advindas do ruído gerado pelo conjunto receptor/antena.

Os valores de MP1 e MP2 são calculados partindo-se das equações de pseudodistância e da fase de batimento da onda portadora (UNAVCO, 2006). As combinações lineares para MP1 e MP2 são dados por (FORTES, 1997):

$$
\begin{aligned}
& \mathrm{MP} 1 \equiv \mathrm{PD}_{1}-\left(1+\frac{2}{\alpha-1}\right) \phi_{1}+\left(\frac{2}{\alpha-1}\right) \phi_{2}=\mathrm{M}_{\mathrm{PD} 1}+\mathrm{B}_{1}-\left(1+\frac{2}{\alpha-1}\right) \mathrm{M}_{\phi_{1}}+\left(\frac{2}{\alpha-1}\right) \mathrm{M}_{\phi_{2}} \\
& \mathrm{MP} 2 \equiv \mathrm{PD}_{2}-\left(\frac{2 \alpha}{\alpha-1}\right) \phi_{1}+\left(\frac{2 \alpha}{\alpha-1}-1\right) \phi_{2}=\mathrm{M}_{\mathrm{PD} 2}+\mathrm{B}_{2}-\left(\frac{2 \alpha}{\alpha-1}\right) \mathrm{M}_{\phi_{1}}+\left(\frac{2 \alpha}{\alpha-1}-1\right) \mathrm{M}_{\phi_{2}}
\end{aligned}
$$

sendo as tendências (bias terms), ou termos de viés, $B_{1}$ e $B_{2}$ resultantes das ambigüidades da fase e são dadas por:

$$
\begin{aligned}
& \mathrm{B}_{1}=-\left(1+\frac{2}{\alpha-1}\right) \lambda_{1} \mathrm{~N}_{1}+\left(\frac{2}{\alpha-1}\right) \lambda_{2} \mathrm{~N}_{2} \\
& \mathrm{~B}_{2}=-\left(\frac{2 \alpha}{\alpha-1}\right) \lambda_{1} \mathrm{~N}_{1}+\left(\frac{2 \alpha}{\alpha-1}-1\right) \lambda_{2} \mathrm{~N}_{2}
\end{aligned}
$$


onde:

$\mathrm{PD}_{1}$ - medidas da pseudodistância na portadora $\mathrm{L} 1$;

$\mathrm{PD}_{2}$ - medidas de pseudodistância na portadora L2;

$\alpha \equiv\left(\frac{f_{1}}{f_{2}}\right)^{2}$ - sendo $f_{1}$ a freqüência em $L 1$ e $f_{2}$ a freqüência em $L 2 ;$

$f_{1}=$ freqüência para $L 1, f_{1}=1575,42 \mathrm{MHz}$;

$\mathrm{f}_{2}=$ freqüência para $L 2, \mathrm{f}_{2}=1227,60 \mathrm{MHz}$;

$\phi_{1}$ - medidas de fase na portadora $L 1$;

$\phi_{2}$ - medidas de fase na portadora L2;

$\mathrm{M}_{\mathrm{PD} 1}$ - representa o efeito do multicaminho em $\mathrm{PD}_{1}$;

$\mathrm{M}_{\mathrm{PD} 2}$ - representa o efeito do multicaminho em $\mathrm{PD}_{2}$;

$M_{\phi_{1}}$ - representa o efeito do multicaminho em $\phi_{1}$;

$\mathrm{M}_{\phi_{2}}$ - representa o efeito do multicaminho em $\phi_{2}$;

$\lambda_{1}=$ comprimento de onda para $L 1, \lambda_{1} \cong 19,03 \mathrm{~cm}$;

$\lambda_{2}=$ comprimento de onda para $\mathrm{L} 2, \lambda_{2} \cong 24,42 \mathrm{~cm}$;

$\mathrm{N}_{1}=$ ambigüidade da fase da onda portadora $L 1$;

$\mathrm{N}_{2}$ = ambigüidade da fase da onda portadora L2.

Analisando-se as equações 3.1 e 3.2, observa-se no segundo membro das mesmas que os indicativos MP1 e MP2 podem ser calculados diretamente a partir das observáveis de pseudodistância e fase. Porém, se analisarmos o terceiro termo dessas equações, verifica-se que os valores de MP dependem do efeito do multicaminho na pseudodistância $\left(\mathrm{M}_{\mathrm{PD}}\right)$ e na fase $\left(\mathrm{M}_{\phi}\right)$ e dos termos de viés $(B)$ originados das ambigüidades da fase. Portanto, independente do valor absoluto calculado para MP1 e MP2, o acompanhamento de sua variação ao longo do tempo fornece informações implícitas sobre a qualidade dos dados. Portanto, se um valor de MP1 muda bruscamente, isso significa que houve um efeito acentuado do multicaminho em $\mathrm{PD}_{1}$ (dado por uma variação de $\mathrm{M}_{\mathrm{PD} 1}$ ) ou ocorreu uma perda de ciclos que provocou uma modificação acentuada de $\mathrm{B}_{1}$ (desprezando, neste caso, 
os efeitos das modificações em $\mathrm{M}_{\phi_{1}}$, por serem os valores do efeito do multicaminho nas fases muito menores que os relativos aos códigos) (FORTES, 1997).

Além disso, os valores calculados para MP1 e MP2 são afetados pelos ruídos advindos das conexões e cabos do receptor e da antena. Nesta pesquisa, o multicaminho nas duas portadoras será escrito sempre como MP1 e MP2, mas sabese que o mesmo é afetado pelos outros fatores, citados anteriormente.

\subsubsection{BERNESE V. 5.0}

O programa Bernese V.5.0, desenvolvido pelo Instituto Astronômico da Universidade de Berna, na Suíça, é utilizado para processamento dos dados dos sistemas de navegação GPS e GLONASS. O programa é composto por vários módulos para a realização do processamento.

O programa Bernese, em sua versão 5.0, utilizado nessa pesquisa, é apropriado para (HUGENTOBLER et al., 2006):

- Processamento rápido de pequenos levantamentos GPS, tanto com a portadora L1 quanto com a portadora L2;

- Processamento automático de redes de monitoramento contínuo;

- Obtenção de soluções livres no ajustamento de redes (free network solutions);

- Resolução de ambigüidades de linhas de base longas (2000 km ou maiores) utilizando órbitas precisas;

- Modelagem da troposfera e da ionosfera;

- Estimativa de erro dos relógios;

- Combinação de diferentes tipos de receptores;

- Processamento combinado de observáveis GPS e GLONASS;

- Determinação de órbitas e estimação dos parâmetros de rotação da Terra.

Em contrapartida, deve-se dizer que, por haver uma grande quantidade de opções, este programa não é de fácil aprendizado. 
As rotinas do Bernese são abertas, havendo a possibilidade de implementá-las conforme a necessidade do usuário.

Pode-se citar como usuários típicos desse programa (HUGENTOBLER et al., 2006):

- Pesquisadores envolvidos com aplicações científicas (pesquisa e educação);

- Agências de mapeamento responsáveis por levantamentos;

- Agências responsáveis por redes GPS permanentes;

- Empresas especializadas em aplicações complexas e que necessitem de confiabilidade e grande produtividade.

A seguir, é apresentada a seqüência de processamento utilizada no programa Bernese V. 5.0 e um breve descritivo sobre cada módulo utilizado:

- POLUPD - converte para o formato do Berneses os parâmetros de rotação da Terra, a partir de arquivos de pólo no formato IERS;

- PRETAB - tem como objetivo obter um arquivo de órbita tabular, ou seja, transformar a órbita precisa (formato SP3), referenciada ao sistema terrestre, em um arquivo de órbita tabular referenciado a um sistema celeste inercial. Adicionalmente, pode ser utilizado para extrair informações do relógio dos satélites e gerar um arquivo de relógio no formato do BERNESE, para ser utilizado no programa CODSPP;

- ORBGEN - prepara a órbita padrão a ser utilizada no processamento a partir da posição dos satélites contida no arquivo de órbita tabular. A órbita padrão é resultado de uma integração numérica das equações de movimento;

- RNXOBV3 - importa os arquivos no formato RINEX para o formato Bernese (binário);

- CODSPP - sua principal tarefa é calcular as correções do relógio do receptor, sincronizando-os com o tempo GPS, além de possibilitar a determinação de coordenadas aproximadas das estações;

- SNGDIF - cria as linhas de base e as armazena em um arquivo;

- MAUPRP - após serem criadas as linhas de base, é possível eliminar ou diminuir significativamente alguns erros inerentes às observações. $O$ módulo tem como finalidade principal, selecionar as perdas de ciclos 
através de um pré-processamento de simples diferença de fase. Se perdas de ciclos forem encontradas o programa tentará corrigir as observações;

- GPSEST - o módulo GPSEST têm como tarefa o ajustamento pelo $M M Q$, sendo o principal programa de estimação de parâmetros do software GPS BERNESE, permitindo estimar diferentes tipos de variáveis, dentre as quais:

- Coordenadas das estações;

- Parâmetros do relógio do receptor;

- Elementos orbitais;

- Ambigüidades;

- Variações do centro de fase da antena;

- Parâmetros de troposfera e;

- Parâmetros de ionosfera;

- RESRMS - após ter sido gerado um arquivo contendo os resíduos do ajustamento pelos mínimos quadrados, este módulo é utilizado para detectar outliers no arquivo de resíduo. Este programa detecta os outliers e os coloca em um arquivo que contém uma lista de observações que foram identificadas como ruins pelo programa. Além disso, ele também mostra um resumo da qualidade das observações GPS;

- SATMRK - tem como objetivo principal editar os arquivos de observações do Bernese, utilizando o arquivo gerado pelo RESRMS, onde constam os outliers;

- GPSEST - na etapa anterior deste módulo foram determinados arquivos de coordenadas e resíduos, a partir de um ajustamento pelo $M M Q$, realizando um processamento das observações GPS, com ambigüidades não resolvidas. Agora, em um segundo processamento realizado pelo GPSEST, o principal objetivo é tentar solucionar as ambigüidades, sem a preocupação de determinar as coordenadas;

- GPSEST - depois de resolvidas as ambigüidades para todas as linhas de base, o módulo GPSEST é utilizado novamente, agora com o objetivo 
de gerar a solução final para as coordenadas das estações, assim como os arquivos de variância-covariância para cada uma das seções;

- COOVEL - este módulo tem como objetivo realizar a propagação das velocidades nas coordenadas da estação de referência. A partir de um arquivo que contém as velocidades, em $X, Y$ e $Z$, da estação de referência. Este módulo propaga as coordenadas ao longo do tempo, sendo necessário para isso informar a época de referência das coordenadas utilizadas. A propagação é calculada para cada dia processado, portanto, as coordenadas de referência mudam diariamente;

- BPE - O "Bernese Processing Engine" (BPE) é parte integrante do programa BERNESE, e permite ao usuário realizar o processamento de dados GPS automaticamente. O BPE executa uma lista de tarefas definidas, que é implementada de acordo com a necessidade do usuário, ou seja, com o tipo de processamento que será realizado. É uma ferramenta de grande utilidade para a otimização e automatização do processamento.

\subsubsection{SERVIÇOS DE PROCESSAMENTO ON-LINE}

Neste item serão apresentados os serviços de processamento on-line utilizados neste trabalho. Todos os serviços aqui descritos estão disponíveis na internet, através de acesso gratuito.

\subsubsection{SERVIÇO AUSPOS}

O serviço de processamento on-line AUSPOS (Australian Surveying and Land Information Group's Online GPS Processing Service) realiza o processamento no modo diferencial, utilizando-se de estações do IGS para determinar as coordenadas 
da estação de interesse. Para isso, é necessário que o usuário submeta através da Internet, dados GPS de dupla freqüência em formato RINEX, observados no modo estático, para que sejam processados. O serviço aceita dados enviados via e-mail ou que, seja informado o servidor de ftp onde os dados estão disponíveis, podendo ser submetidos até 7 arquivos por vez para processamento.

Para verificação dos arquivos RINEX o AUSPOS utiliza o programa TEQC para que sejam detectados possíveis problemas que possam afetar o processamento, além de aceitar que sejam enviados arquivos utilizando os seguintes tipos de compressão: Hatanaka (*.05d), .Z, .GZ e .ZIP. O formato Hatanaka criado por Yuki Hatanaka (HATANAKA, 1998), é um tipo de compressão específica para arquivos GPS em formato RINEX; arquivos do tipo .Z são criados utilizando o comando Compress do sistema UNIX, .GZ criados pelo programa Gzip, e .ZIP são criados no sistema Windows. No processamento dos dados GPS o AUSPOS utiliza o programa MicroCosm, desenvolvido pela Van Martin Systems Inc (MicroCosm, 2005).

Este serviço utiliza para o processamento estações e efemérides precisas do IGS e pode trabalhar com dados GPS coletados em qualquer lugar do globo terrestre (AUSTRALIAN SURVEYING AND LAND INFORMATION GROUP'S ONLINE GPS PROCESSING SYSTEM, 2005). Como as efemérides precisas demoram aproximadamente 15 dias para serem calculadas e disponibilizadas, quando o usuário envia um arquivo coletado recentemente para o qual as efemérides precisas ainda não tenham sido calculadas, o serviço utiliza para o processamento as efemérides rápidas ou ultra-rápidas, fornecidas pelo IGS. As estações de referência utilizadas no processamento são escolhidas pelo serviço, sem que o usuário possa indicar as estações de sua preferência.

Para o envio dos arquivos, devem-se seguir os seguintes passos:

- Acessar o sítio do serviço AUSPOS (http://www.ga.gov.au/bin/gps.pl), escolher a maneira de envio dos dados, por upload na própria página ou por um endereço de ftp;

- Deve-se escolher o número de arquivos a serem enviados, em um máximo de sete arquivos. Para se enviar mais de um arquivo de uma única vez é necessário que os mesmos sejam consecutivos, sem que haja um único dia faltante na seqüência enviada; 
- Posteriormente é necessário, através de um browser, selecionar cada arquivo a ser enviado, inserir a altura da antena, o tipo de antena, conforme nomenclatura do NGS, adicionar o endereço de e-mail para onde os resultados deverão ser enviados, apertar o botão submit;

- Uma nova janela será aberta mostrando a seqüência de envio dos dados.

Após o processamento dos dados, um relatório em formato PDF (Portable Document Format) gerado pelo serviço é enviado para o e-mail designado pelo usuário. O tempo de resposta varia de alguns minutos a algumas horas, dependendo do número de arquivos enviados. O relatório resultante do processamento traz informações importantes para o usuário, como:

- Dias processados e horários de início e fim de cada arquivo;

- Estações utilizadas no processamento;

- Coordenadas cartesianas e geodésicas das estações referidas ao ITRF2000 (International Terrestrial Reference Frame - época 2000), e respectivos desvios padrão, apenas para as coordenadas cartesianas;

- Quadro contendo informações sobre o RMS de cada estação, número de observações coletadas e porcentagem de observações descartadas;

- Informações sobre os modelos utilizados para: modelagem das observáveis (modelos de troposfera, ionosfera e de correção do centro de massa dos satélites), modelagem orbital (modelo do potencial gravitacional, de maré oceânica e de maré terrestre), e modelagem da estação (modelos de precessão, de nutação, de movimento do pólo, de rotação da Terra e de movimentação da Placa);

- Recomendação para verificar as seguintes informações para validação dos resultados: diferença das coordenadas a priori e as calculadas não deve ser maior que $15 \mathrm{~m}$, a precisão das coordenadas não deve ser maior que $0,025 \mathrm{~m}$ e a porcentagem de observações excluídas não devem ultrapassar $25 \%$. 


\subsubsection{SERVIÇO CSRS-PPP}

O serviço de processamento on-line CSRS-PPP (Canadian Spatial Reference System - Precise Point Positioning), disponibilizado pelo "Canadian Geodetic Service of Natural Resources Canada" fornece aos usuários a possibilidade de submeter através da Internet, dados GPS de simples ou dupla freqüência em formato RINEX, observados em modo estático ou cinemático. A qualidade dos resultados depende do tipo de equipamento utilizado pelo usuário, da dinâmica atmosférica e da duração da sessão observada (GEODETIC SURVEY DIVISION, 2005).

O processamento é realizado no modo absoluto, e utiliza arquivos de órbita precisa e de correção dos relógios fornecidos pelo IGS. Como descrito no serviço anterior, na falta das efemérides precisas, o serviço utiliza para o processamento as efemérides rápidas ou ultra-rápidas.

O CSRS-PPP aceita os seguintes tipos de compressão: Hatanaka, .Z, .GZ e .ZIP e no processamento dos dados GPS utiliza o programa GPSPACE, desenvolvido pelo próprio NRCAN (Natural Resources Canada).

Para o envio dos arquivos, devem-se seguir os seguintes passos:

- Acessar o sítio do serviço CSRS-PPP, disponível no endereço (http://www.geod.nrcan.gc.ca/online data e.php), fazer um cadastro onde será gerado o nome de usuário e a senha. Depois disto pode-se acessar o serviço, e selecionar:

- um arquivo RINEX no campo especificado;

- tipo de coleta dos dados: estático ou cinemático;

- sistema de referência para as coordenadas calculadas: NAD83 (North American Datum 1983) ou ITRF2000 e;

- e-mail de recebimento do relatório.

- Ao apertar o botão start, os dados serão enviados ao CSRS-PPP para que sejam processados. Ao final do envio uma mensagem será exibida avisando se os dados foram ou não enviados.

O resultado do processamento é enviado para o e-mail do usuário em aproximadamente dois minutos, e apresenta as coordenadas calculadas colocadas 
diretamente no corpo do e-mail, além de ser disponibilizado um link onde podem ser encontrados os relatórios completos, que trazem as seguintes informações:

- Dia processado e horário de início e fim do arquivo;

- Desvio a priori e a posteriori do código e da fase;

- Coordenadas geodésicas calculadas, referidas ao ITRF2000 e respectivos desvios padrão;

- Parâmetros estimados para: atraso troposférico, deriva do relógio da estação, resíduos da fase, do código e das ambigüidades para cada satélite;

- Sumário com as correções realizadas para cada época;

- Sumário com as informações sobre o arquivo, os parâmetros utilizados no processamento e as opções utilizadas no processamento.

\subsubsection{SERVIÇO SCOUT}

O serviço de processamento on-line SCOUT (Scripps Coordinate Update Tool), disponibilizado pelo SOPAC (Scripps Orbit and Permanent Array Center) dos Estados Unidos, realiza o processamento no modo relativo, utilizando-se de estações do IGS para determinar as coordenadas da estação de interesse. Devem ser enviados dados GPS de dupla freqüência em formato RINEX, observados no modo estático, para que os mesmos sejam processados. Para o envio dos dados é necessário que seja informado o endereço do servidor de ftp onde os dados estão colocados, ou então, enviar os dados para o próprio ftp do SCOUT e através de um browser carregá-los, sendo permitido o envio de apenas um arquivo por vez.

O SCOUT também utiliza o programa TEQC para que sejam detectados possíveis problemas nos arquivos RINEX, além de aceitar que sejam enviados arquivos utilizando os mesmos tipos de compactação descritos no serviço AUSPOS, com exceção da extensão .ZIP, que não é aceita. O SCOUT utiliza para o processamento dos dados o programa GAMIT, desenvolvido pelo "Department of Earth Atmospheric and Planetary Sciences, Massachusetts Institute of Technology (MIT)" (GAMIT, 2005 - http://www-gpsg.mit.edu/ simon/gtgk/). 
O serviço utiliza para o processamento estações e efemérides precisas do IGS, e como descrito nos serviços anteriores, na falta das efemérides precisas, o serviço utiliza para o processamento as efemérides rápidas ou ultra-rápidas (SCRIPPS COORDINATE UPDATE TOOL, 2005). As estações de referência são definidas pelo próprio programa.

Para o envio dos arquivos, devem-se seguir os seguintes passos:

- Acessar o sítio do serviço SCOUT (http://sopac.ucsd.edu/cgibin/SCOUT.cgi) e informar o endereço de e-mail para onde os relatórios de processamento devam ser enviados;

- Escolher a maneira de envio dos dados, por um endereço de ftp do usuário ou por dados carregados no próprio ftp do serviço;

- Ao apertar o botão submit, uma nova janela é aberta, onde é mostrada a verificação do arquivo RINEX feita pelo TEQC. Além disso, ainda deve ser informado pelo usuário: tipo de receptor e tipo/altura da antena utilizados na coleta;

- Deve-se apertar o botão submit novamente, após isto serão apresentadas informações das estações do IGS utilizadas para o processamento, número de arquivos do usuário que estão em processamento e o tempo aproximado de envio dos resultados para o email designado. O relatório de processamento pode demorar de 30 minutos a algumas horas para ser enviado, isso varia de acordo com o número de arquivos que o usuário tenha enviado em seqüência.

Após o processamento dos dados, os resultados gerados pelo serviço são enviados para o e-mail designado pelo usuário. Não é enviado um relatório completo, as informações são colocadas diretamente no corpo do e-mail, sendo elas:

- Estações utilizadas no processamento;

- Coordenadas cartesianas e geodésicas das estações, referidas ao ITRF2000, e respectivos desvios padrão e;

- Tipo de órbita utilizada. 


\subsubsection{SERVIÇO AG-JPL}

O AG-JPL (Auto Gipsy - Jet Propulsion Laboratory), é um serviço norteamericano administrado pela NASA que realiza processamento on-line no modo relativo. Para isso, devem ser enviados dados GPS de dupla freqüência em formato RINEX, observados no modo estático (JET PROPULSION LABORATORY, 2005). Dentre os serviços aqui descritos é o que apresenta em seu sítio menos informações ao usuário.

O Auto GIPSY aceita arquivos compactados em formato Hatanaka com os tipos de compressão .Z e .GZ, sendo que, utiliza para o processamento dos dados o programa GIPSY-OASIS (GPS-Inferred Positioning System and Orbit Analysis SImulation Software), desenvolvido pelo Orbiter and Radio Metric Systems Group (ORMS) da NASA (GIPSY-OASIS, 2005 - http://gipsy.jpl.nasa.gov/orms/goa/).

Para o envio dos dados é necessário que seja enviado um e-mail para ag@cobra.jpl.nasa.gov, informando no corpo da mensagem o endereço de um servidor de ftp do usuário onde o arquivo a ser processado está disponível, e no título da mensagem deve conter o texto "Static".

Após o processamento dos dados, um e-mail de resposta intitulado "Output" é enviado ao usuário, constando o endereço ftp onde podem ser encontrados os resultados do processamento e um aviso de que os mesmos estarão disponíveis apenas por alguns dias, sendo que, o e-mail de resposta ao usuário demora aproximadamente 10 minutos. No endereço disponibilizado podem ser encontrados os arquivos de saída, que trazem as seguintes informações:

- As coordenadas geodésicas calculadas (ITRF2000) e respectivos desvios padrão e;

- Parâmetros de correção calculados para: atraso troposférico e deriva do relógio da estação. 
A Geodésia, assim como outras ciências, realiza e utiliza observações que estão relacionadas com o tempo. Ao conjunto destas observações dá-se o nome de séries temporais. Neste capítulo serão apresentados alguns conceitos e o método conhecido como média móvel, para a análise das séries temporais.

\subsubsection{SÉRIES TEMPORAIS}

Uma série temporal é um conjunto de observações ordenadas ao longo do tempo, geralmente em intervalos iguais (MORETTIN, 1987).

Podemos tomar como exemplo de séries temporais os valores mensais de temperatura de uma cidade, os valores diários de registros maregráficos em Cananéia e a seqüência de observáveis GPS na estação NEIA.

Uma série temporal pode ser representada matematicamente pelos valores $\left(\mathrm{Y}_{1}, \mathrm{Y}_{2}, \ldots, \mathrm{Y}_{\mathrm{n}}\right)$ de uma variável $\mathrm{Y}$ nos tempos $\left(\mathrm{t}_{1}, \mathrm{t}_{2}, \ldots, \mathrm{t}_{\mathrm{n}}\right)$. Portanto, $\mathrm{Y}$ é uma função de $\mathrm{t}$ sendo escrita por $\mathrm{Y}=\mathrm{F}(\mathrm{t})$. Podendo ser representada graficamente por meio da construção de um gráfico (Figura 16) de Y em função de t (SPIEGEL, 1994).

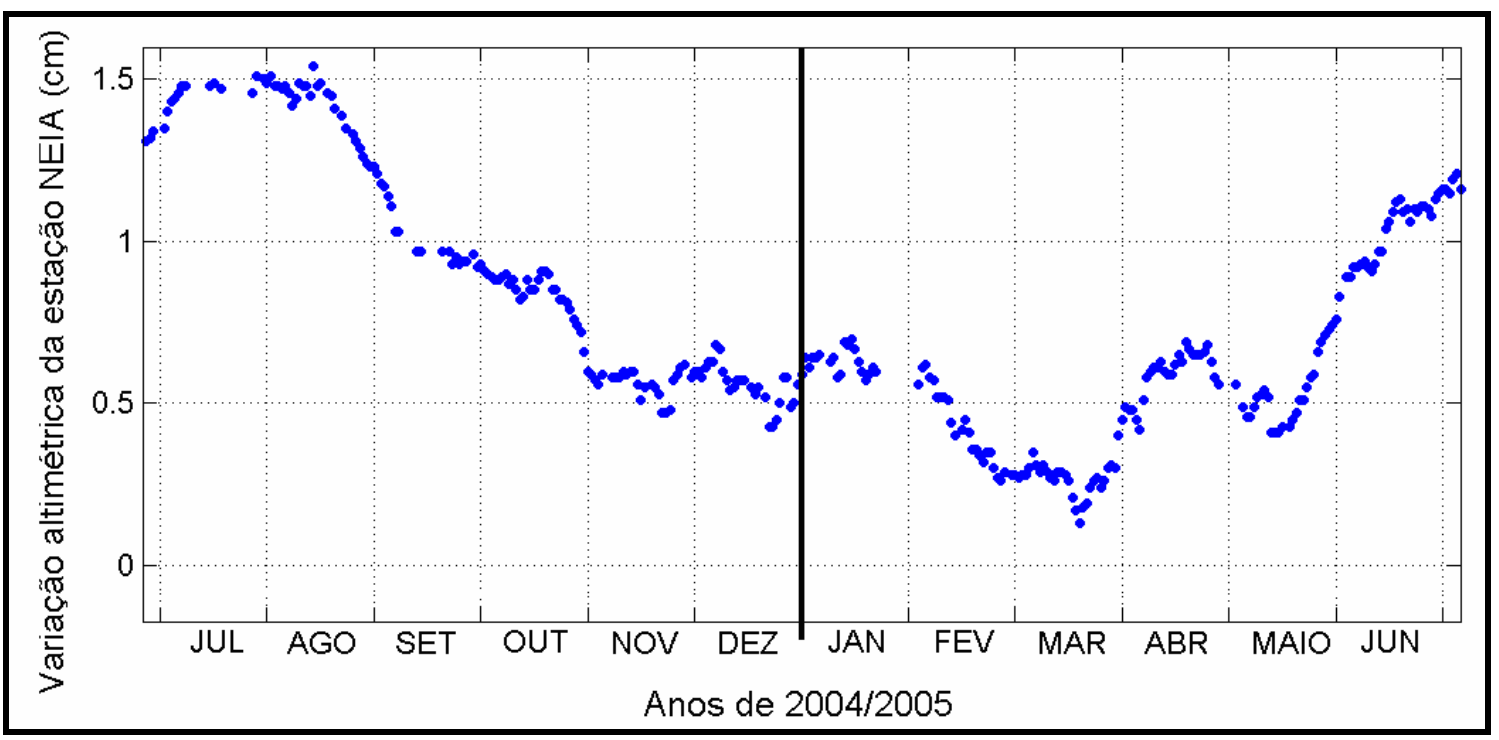

Figura 16: Exemplo de gráfico de representação temporal 


\subsubsection{Movimentos CARActerísticos das SÉRIES TEMPORAIS}

Apesar de existirem sofisticadas técnicas de análises de séries temporais, o gráfico ainda é uma boa alternativa para se identificar algumas características dessas observações temporais, como por exemplo, tendências ou sazonalidades (CHATFIELD 1996 apud SILVA, 2005).

Estudos realizados com séries temporais, e sua posterior análise, podem revelar movimentos ou variações características importantes (SPIEGEL, 1994).

\subsubsection{ClAsSificaÇÃo dos MOVIMENTOS dAS SÉRIES TEMPORAIS}

Os movimentos que caracterizam uma série temporal são divididos em quatro classes principais, geralmente chamadas de componentes de uma série temporal, sendo elas (SPIEGEL, 1994):

1) Movimentos de longo prazo ou seculares: está ligado à direção geral, segundo a qual parece que o gráfico da série temporal se desenvolve em um longo intervalo de tempo. Para algumas séries temporais pode ser adequado apresentá-la como uma reta ou curva de tendência, e pode-se citar como exemplo, a deriva continental;

2) Variações cíclicas: referem-se às oscilações a longo prazo ou aos desvios em torno da reta ou curva de tendência. Esses ciclos podem ser ou não periódicos, isto é, podem ou não seguir padrões análogos depois de intervalos de tempo iguais. Como exemplo de variação cíclica pode-se citar as explosões solares, que afetam o GPS;

3) Variações sazonais ou estacionais: está ligado a padrões idênticos, ou quase idênticos, que uma série temporal parece obedecer durante os mesmos períodos em anos sucessivos. Esses movimentos resultam de eventos periódicos que ocorrem anualmente como, por exemplo, o comportamento da ionosfera. Apesar das variações sazonais estarem geralmente referidas à periodicidade anual, os intervalos podem ser 
estendidos para qualquer espaço de tempo, seja ele mensal, semanal, diário ou horário, podendo variar conforme o tipo de dados que se tenha para analisar;

4) Movimentos irregulares ou aleatórios: referem-se aos movimentos esporádicos nas séries temporais, provocados por eventos casuais como explosões solares (causando bruscas variações na ionosfera). É certo afirmar que esses eventos produzem variações somente por um período curto de tempo, mas podem ser tão intensos que acarretem novos movimentos cíclicos ou de alguma outra natureza.

\subsubsection{ANÁLISE DAS SÉRIES TEMPORAIS}

A análise das séries temporais se dá através de uma descrição (usualmente matemática) dos movimentos que a compõem (SPIEGEL, 1994). Supondo-se uma série temporal ideal, podemos visualizar esses processos através da Figura 17.

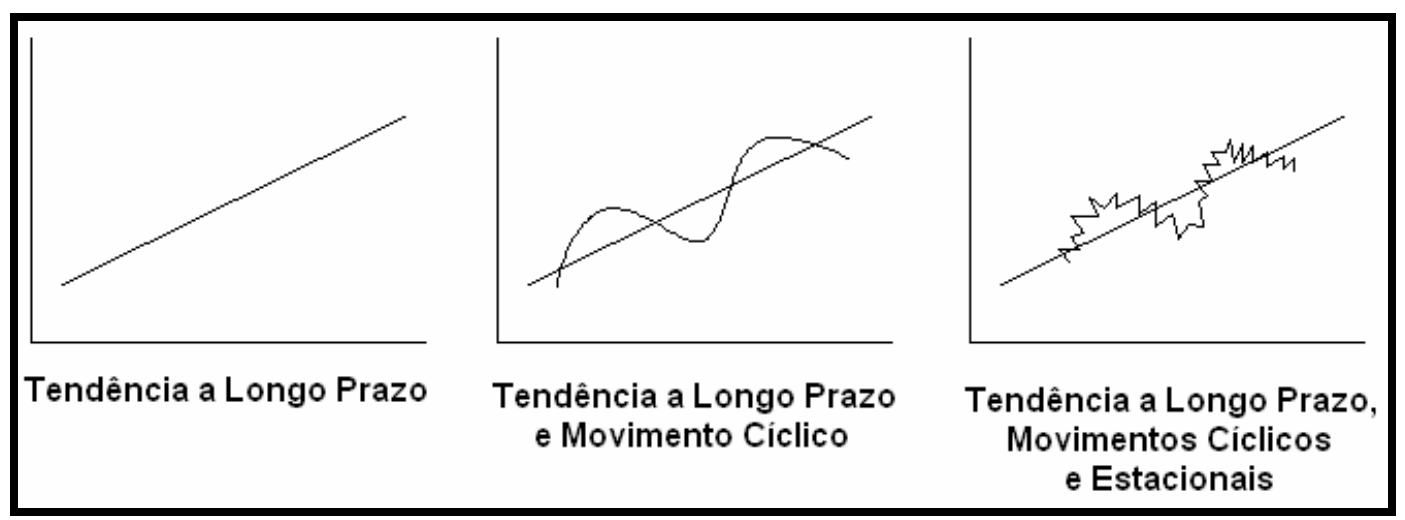

Figura 17: Exemplos de séries temporais ideais Fonte: adaptado de SPIEGEL, 1994.

Pode-se dizer que a variável $\mathrm{Y}$ da série temporal é o produto ou a soma das variáveis T, C, S e I, sendo respectivamente, os movimentos de tendências, cíclicos, sazonais e irregulares, portanto (SPIEGEL, 1994): 


$$
\begin{aligned}
& \mathrm{Y}=\text { T.C.S.I } \\
& \mathrm{Y}=\mathrm{T}+\mathrm{C}+\mathrm{S}+\mathrm{I}
\end{aligned}
$$

\subsubsection{OBJETIVOS DA ANÁLISE DE SÉRIES TEMPORAIS}

A partir de uma série temporal $\mathrm{Y}\left(\mathrm{t}_{1}\right), \mathrm{Y}\left(\mathrm{t}_{2}\right), \ldots, \mathrm{Y}\left(\mathrm{t}_{\mathrm{n}}\right)$, pode-se estar interessado em (MORETTIN, 1987):

1) Investigar o mecanismo gerador da série temporal; por exemplo, analisando uma série maregráfica, pode-se querer saber como as ondas foram geradas;

2) Fazer previsões de valores futuros da série, podendo ser previsões a curto ou longo prazo;

3) Apenas descrever o comportamento da série, podendo-se, neste caso, utilizar ferramentas úteis como verificação de tendências, de ciclos sazonais, além da construção de gráficos, histogramas e diagramas de dispersão;

4) Procurar periodicidades relevantes nos dados, podendo ser de grande importância a análise espectral.

\subsubsection{MÉdias Móveis (Alisamento de SÉRIES TEMPoraIS)}

Dado um conjunto de números: $\mathrm{Y}_{1}, \mathrm{Y}_{2}, \ldots, \mathrm{Y}_{\mathrm{n}}$, é definida a média móvel de ordem $\mathrm{N}$, obtida pela seqüência das médias aritméticas:

$$
\frac{Y_{1}+Y_{2}+\ldots+Y_{n}}{n}, \frac{Y_{2}+Y_{3}+\ldots+Y_{n+1}}{n}, \frac{Y_{3}+Y_{4}+\ldots+Y_{n+2}}{n}, \ldots
$$


Se os dados utilizados são anuais ou mensais, as médias móveis de ordem $\mathrm{N}$ são chamadas, respectivamente de média móvel de $\mathrm{N}$ anos ou de $\mathrm{N}$ meses, mas pode-se utilizar qualquer unidade de tempo desejada.

O nome média móvel é utilizado porque, a cada período, a observação mais antiga é substituída pela mais recente, calculando-se uma nova média (MORETTIN, 1987).

Uma importante propriedade das médias móveis é a de reduzir a variação apresentada por um conjunto de dados. Em se tratando de séries temporais, essa propriedade é utilizada para eliminar flutuações indesejáveis, sendo denominada alisamento das séries temporais (SPIEGEL, 1994).

Utilizando-se médias móveis de ordens apropriadas, pode-se eliminar as variações cíclicas, sazonais e irregulares, havendo a conservação do movimento de tendência. A grande desvantagem desse método é que os dados do início e fim da série desaparecem, e isso pode ser um sério problema quando a quantidade de dados não for muito grande (SPIEGEL, 1994).

\subsection{TÉCNICA DE FILTRAGEM}

Quando ocorre a existência de pontos com valores muito discrepantes em relação à maioria do restante da amostra, deve-se realizar a filtragem dos dados a fim de se observar mais facilmente determinados movimentos característicos da série analisada. A média e o desvio padrão, neste caso, podem não representar de forma coerente o todo, e, portanto, não podem ser utilizados para realizar a filtragem dos dados. Assim sendo, deve-se buscar outro método para realizar tal tarefa.

Um método eficiente a ser utilizado nestas condições, é o método dos quantis com a utilização de boxplots, pois o mesmo apresenta-se como um procedimento eficaz para a eliminação de outliers. A seguir, o método é descrito detalhadamente. 


\subsubsection{MÉTODO DOS QUANTIS}

Tanto a média quanto o desvio padrão podem não ser medidas adequadas para representar um determinado conjunto de dados, pois (MORETTIN, 2006):

- São afetados, de forma exagerada, por valores extremos;

- Apenas com estes dois valores não se tem idéia da simetria ou assimetria da distribuição.

De modo a contornar essas limitações, outras medidas têm de ser consideradas, como, por exemplo, a mediana.

A mediana é um valor que divide os dados exatamente no meio, deixando metade dos dados abaixo e metade acima de seu valor. A partir da mediana, podese definir uma medida, chamada quartil de ordem $p$ ou $p$-quartil, indicada por $q(p)$, onde p é uma porção qualquer entre zero e um $(0<p<1)$, tal que $100 p \%$ das observações sejam menores do que $q(p)$. A seguir, são mostrados alguns quantis $e$ seus nomes particulares (MORETTIN, 2006):

$$
\begin{aligned}
& -q(0,25): 1^{\text {ㅇ }} \text { Quartil } \\
& -q(0,50): \text { Mediana }=2^{\circ} \text { o Quartil } \\
& -q(0,75): 3^{\circ} \text { o Quartil }
\end{aligned}
$$

Os quantis $q(0,25)=q_{1}, q(0,5)=q_{2}$ e $q(0,75)=q_{3}$ são medidas de localização resistentes de uma distribuição. Diz-se que uma medida de localização ou dispersão é resistente quando a mesma for pouco afetada por mudanças de uma pequena porção dos dados. A mediana é uma medida resistente, ao passo que a média e o desvio padrão não o são (MORETTIN, 2006).

Os cinco valores: valor mínimo da amostra $\left(x_{(1)}\right)$, $1^{\circ}$ quartil $\left(q_{1}\right), 2^{\circ}$ quartil $\left(q_{2}\right), 3^{\circ}$ quartil $\left(q_{3}\right)$ e valor máximo da amostra $\left(x_{(n)}\right)$ são importantes para se verificar a assimetria da distribuição dos dados, sendo que, a maneira de representar graficamente a mediana e os quantis é através de um diagrama, chamado de boxplot.

Para construir este diagrama (Figura 18), considerasse um retângulo onde estão representados a mediana e os $1^{\circ}$ e $3^{\circ}$ quartis. A partir do retângulo, para cima, segue uma linha até o ponto de valor máximo da amostra que não exceda $\mathrm{LS}=\mathrm{q}_{3}+\left(1,5 *\left(\mathrm{q}_{3}-\mathrm{q}_{1}\right)\right)$, sendo LS o limite superior. De modo similar, da parte 
inferior do retângulo, para baixo, segue uma linha até o ponto de valor mínimo da amostra que não seja menor do que $L I=q_{1}-\left(1,5^{*}\left(q_{3}-q_{1}\right)\right)$, onde $L I$ é o limite inferior. Os valores compreendidos entre esses dois limites (LS e LI) são chamados valores adjacentes. As observações que estiverem acima do limite superior ou abaixo do limite inferior estabelecidos são chamadas pontos exteriores. Essas são observações destoantes das demais e podem ou não ser o que chamamos de outliers ou valores atípicos (MORETTIN, 2006).

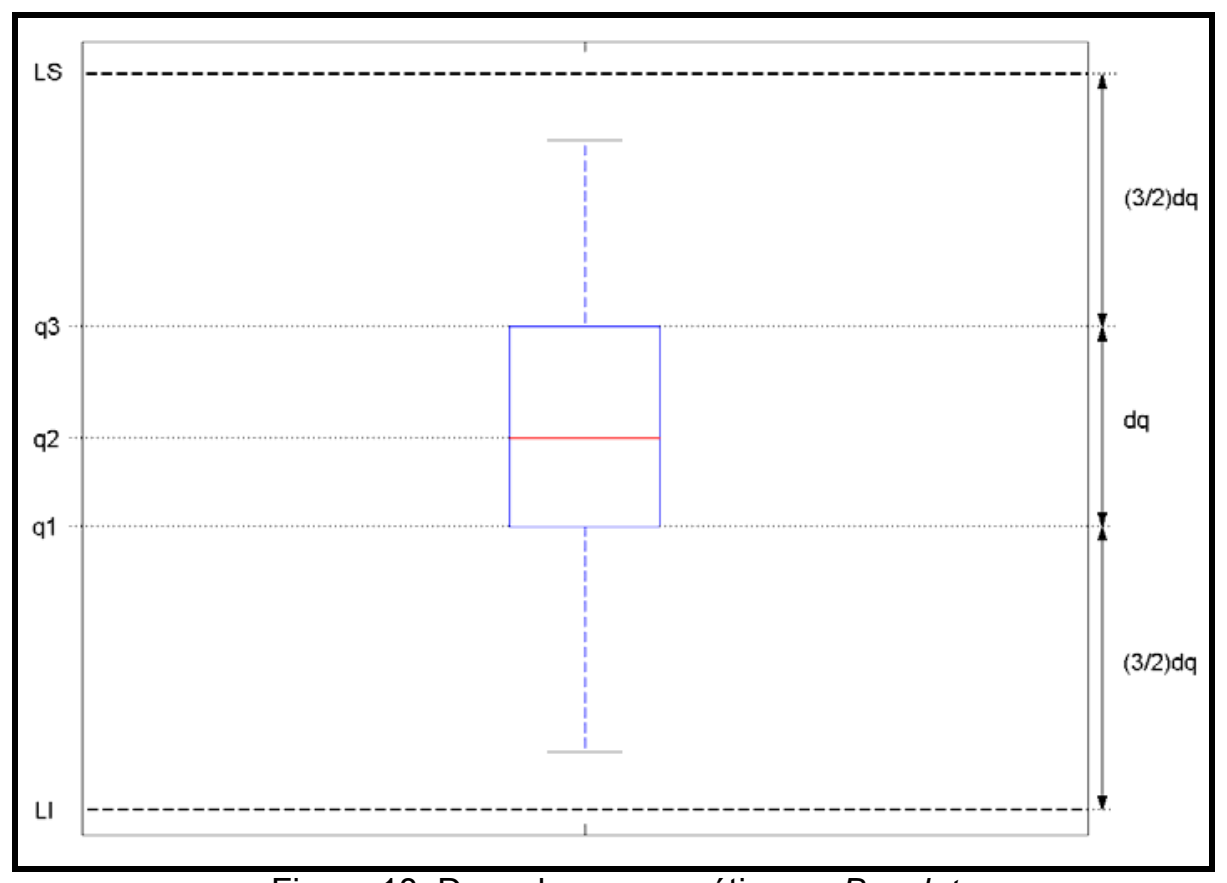

Figura 18: Desenho esquemático ou Boxplot

Fonte: adaptado de Morettin, 2006

O boxplot dá uma idéia da posição, dispersão, assimetria, caudas e dados discrepantes. A posição central é dada pela mediana e a dispersão por $d_{q}=q_{3}-q_{1}$. As posições relativas de $\mathrm{q}_{1}, \mathrm{q}_{2}$ e $\mathrm{q}_{3}$ dão a noção da assimetria da distribuição (MORETTIN, 2006).

Do ponto de vista estatístico, um outlier pode ser produto de um erro de observação ou de arredondamento. Na prática, o termo outlier têm o mesmo significado de: pontos ou valores exteriores, e observações fora de lugar, discrepantes ou atípicas.

A justificativa para utilizar os limites, LI e LS, para definir as observações atípicas é a seguinte: considere uma curva normal com média zero, e portanto, com mediana zero. Pode-se verificar, através da tabela de distribuição normal padrão, 
que se $q 1=-0,6745, q 2=0$ e q3 $=0,6745$ temos, portanto, $d q=1,349$. Segue-se que os limites são $\mathrm{LI}=-2,698$ e $\mathrm{LS}=2,698$. A área entre estes dois valores, embaixo da curva normal, é 0,993 , ou seja $99,3 \%$ da distribuição está entre estes dois valores, sendo que, para dados com uma distribuição normal, os pontos exteriores constituirão cerca de $0,7 \%$ da distribuição (MORETTIN, 2006). 


\section{PROCESSAMENTO E ANÁLISE DOS DADOS}

Neste capítulo serão apresentadas as seqüências de processamento e a análise dos resultados gerados com o uso dos programas TEQC e Bernese V5.0, e dos serviços de processamento on-line AUSPOS, CSRS-PPP, SCOUT e AG-JPL.

\subsection{PRÉ-PROCESSAMENTO UTILIZANDO TEQC}

Os arquivos que originalmente continham 24 horas de dados de observação foram divididos em 2 arquivos de 12 horas, sendo um arquivo de 0 h às $12 \mathrm{hs}$ UTC, e o outro de $12 \mathrm{hs}$ às $23 \mathrm{~h} 59 \mathrm{~min}$ UTC. Para se dividir o arquivo original em duas partes foi utilizado o próprio programa TEQC. Foram analisados nesta etapa do trabalho os dados do período completo de coleta da estação NEIA, compreendido entre janeiro de 2002 e abril de 2006.

O programa TEQC foi utilizado para gerar os indicativos de qualidade da estação NEIA. Para extração dos resultados, foi criado um arquivo em lote (BAT) que repetisse para todos os arquivos RINEX a seguinte linha de comando: Teqc +qc -plot-week???? -set_mask 10 neia???1.??o.

O comando $(+q c)$ deve ser colocado para utilizar o modo de controle de qualidade do TEQC, (-plot) para que não fossem gerados arquivos de saída que não seriam utilizados neste trabalho, (-week) para inserção da semana GPS, (-set_mask 10) para utilizar apenas observações acima da máscara de $10^{\circ}$ e em seguida 0 nome do arquivo que passaria pelo controle de qualidade.

$\mathrm{O}$ arquivo em lote é um tipo de arquivo onde podem ser inseridos vários comandos a serem executados ao invés de ter de escrevê-los um a um em linha de comando. Pode-se criá-lo utilizando um editor de texto para escrever os comandos necessários e depois de pronto deve-se salvá-lo com a extensão BAT, o que o torna um arquivo executável. 


\subsubsection{Resultados e ANÁlises}

Para extrair as informações também foi criado um arquivo em lote que, depois de executado, gerava um arquivo de nome igual ao arquivo RINEX de origem, mas com a extensão XXS (onde XX é o ano das observáveis coletadas). Por exemplo, o arquivo RINEX neia0011.04o, depois do processamento tem-se a saída neia0011.04S, sendo que, a quantidade de arquivos de saída (.XXS) será igual ao número de arquivos RINEX (.XXo) processados.

Dentro do arquivo S (ANEXO A) estão as informações extraídas pelo TEQC de cada arquivo RINEX, sendo elas:

- Horário de início e fim do arquivo;

- Tempo total de coleta de dados;

- Intervalo de coleta;

- Número de observações possíveis no período observado;

- Número de observações efetivamente coletadas no período observado;

- Multicaminho em L1 (MP1);

- Multicaminho em L2 (MP2);

- Deriva do relógio e;

- Perdas de ciclos.

As informações desejadas (número de horas coletadas, multicaminho em L1 e L2, número total de observações e perdas de ciclos) de cada arquivo foram extraídas utilizando um script feito em LINUX. O script é um tipo de arquivo executável similar ao arquivo em lote criado em DOS. Após a extração das informações necessárias os dados foram tabulados e os gráficos gerados.

Para facilitar, o período compreendido entre Oh às 12:00hs UTC foi chamado de $1^{\circ}$ período, e o que vai das $12: 00$ hs às $23: 59 \mathrm{hs}$ UTC foi chamado de $2^{\circ}$ período.

Todas as classes de ocorrência definidas nesta pesquisa foram determinadas a partir da análise visual dos resultados. 


\subsubsection{TOTAL DE HORAS COLETADAS}

O total de horas coletadas permite verificar o quanto a estação foi eficiente na coleta dos dados, permitindo monitorar as possíveis perdas.

Os histogramas (Figuras 19 e 20) e o Quadro 3, a seguir, apresentam o número de horas coletadas e sua freqüência de ocorrência. Deve-se perceber, nos histogramas, que a linha tracejada em vermelho representa uma linha de corte, e acima dela encontra-se o valor para a maior classe de ocorrência. Isso foi necessário para ampliar o histograma, pois, senão, não seria possível visualizar as classes de menor ocorrência. Além disso, o valor máximo do eixo y nos dois histogramas é diferente.

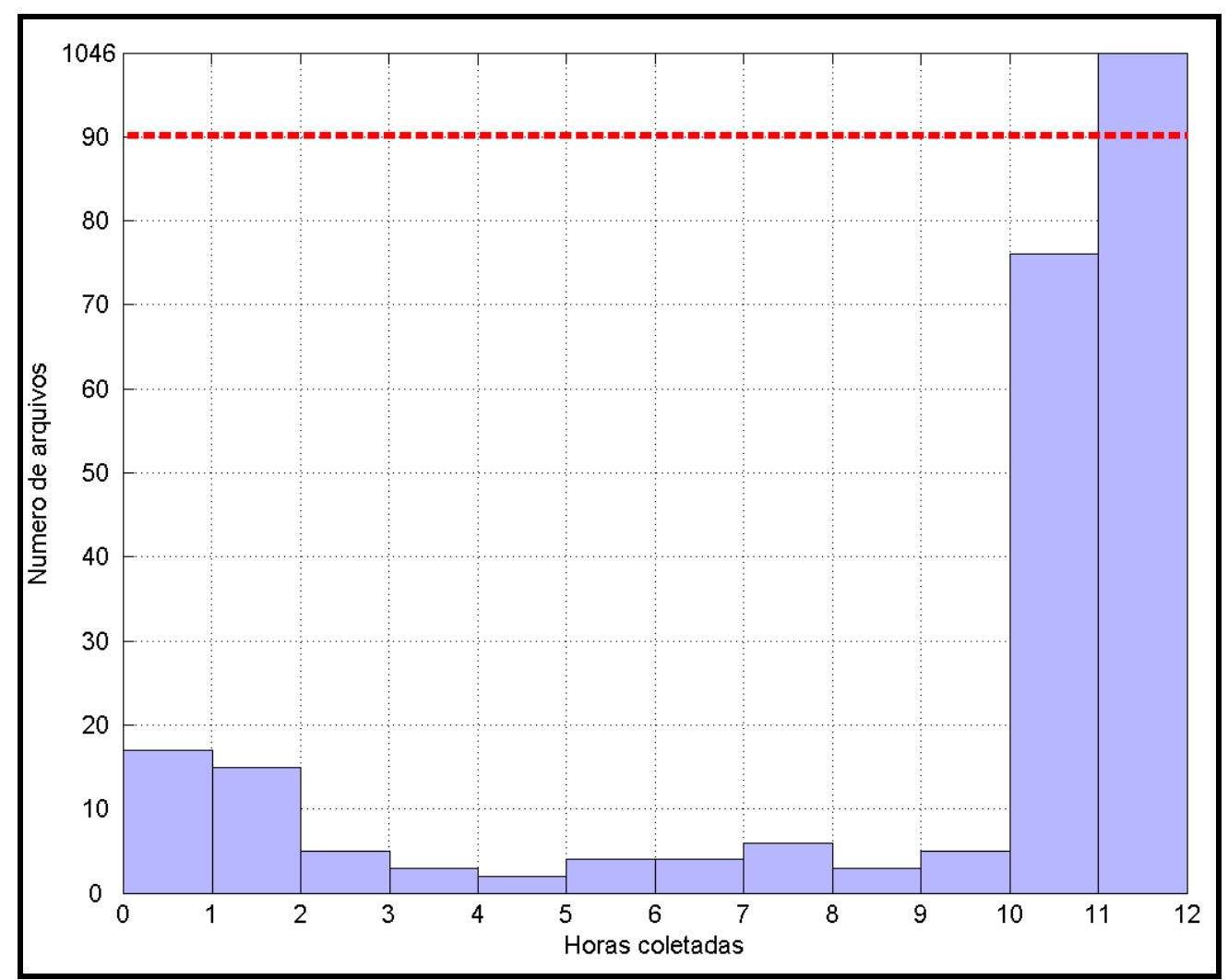

Figura 19: Histograma do número de horas coletadas por sessão no $1^{0}$ período. 


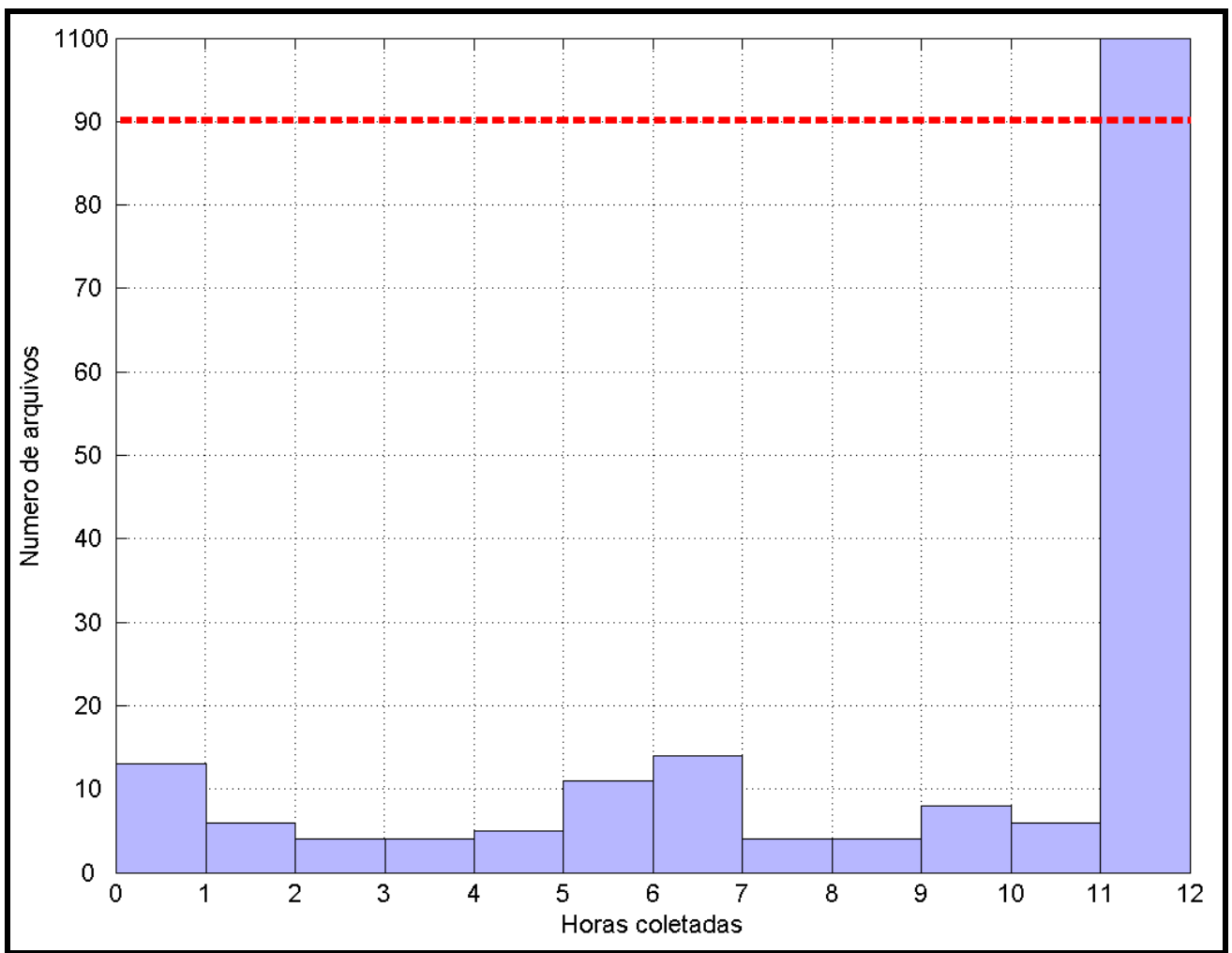

Figura 20: Histograma do número de horas coletadas por sessão no $2^{0}$ período.

\begin{tabular}{|c|c|c|}
\hline \multirow{2}{*}{ Horas Coletadas } & \multicolumn{2}{|c|}{ № de arquivos (\% da amostra) } \\
\cline { 2 - 3 } & 1o período & 20 período \\
\hline $0 \vdash 2$ & $32(2,7 \%)$ & $19(1,6 \%)$ \\
\hline $2 \vdash 4$ & $8(0,7 \%)$ & $8(0,7 \%)$ \\
\hline $4 \vdash 6$ & $6(0,5 \%)$ & $16(1,4 \%)$ \\
\hline $6 \vdash 8$ & $10(0,8 \%)$ & $21(1,8 \%)$ \\
\hline $8 \vdash 10$ & $8(0,7 \%)$ & $14(1,2 \%)$ \\
\hline $10 \vdash 12$ & $1122(94,6 \%)$ & $1106(93,4 \%)$ \\
\hline
\end{tabular}

Quadro 3 - Total de horas coletadas por sessão

Observando-se o Quadro 3 verifica-se que, para $01^{\circ}$ período, de um total de 1186 arquivos analisados, 1122 continham mais que 10 horas de observação, ou seja, $94,6 \%$ do total. No $2^{\circ}$ período, de um total de 1184 arquivos processados, 1106 $(93,4 \%)$ possuíam mais de 10 horas de coleta. O número médio de horas coletadas para o $1^{\circ}$ período foi de 11 horas e 27 minutos, e para o $2^{\circ}$ período o tempo médio coletado foi de 11 horas e 33 minutos. 


\subsubsection{TOTAL DE OBSERVAÇÕES COLETADAS}

O número de observações coletadas é importante para monitorar o funcionamento da estação e verificar se a mesma não sofre perdas constantes em suas épocas de coleta.

Os histogramas (Figuras 21 e 22) apresentam o número de observações coletadas, divididas em classes de ocorrência encontradas para cada período. Para o 1ํ período, de um total de 1186 arquivos analisados, $933(78,7 \%)$ continham mais que 15.000 observações coletadas. No $2^{\circ}$ período, de um total de 1184 arquivos processados, $925(78,2 \%)$ possuíam mais de 15.000 observações coletadas, sendo que, estes valores podem ser vistos no Quadro 4.

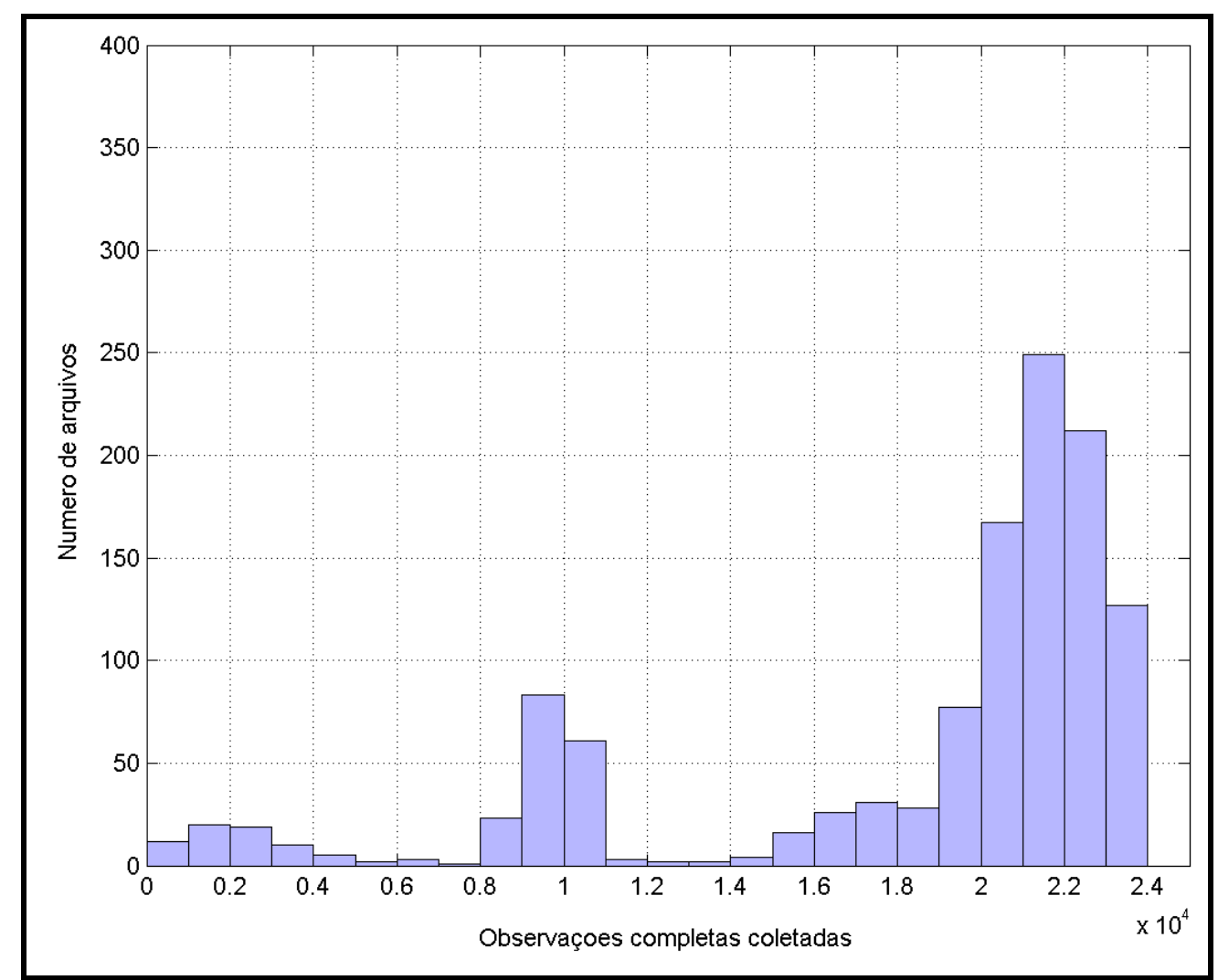

Figura 21: Histograma do número de observações coletadas por sessão no 1ํ período. 


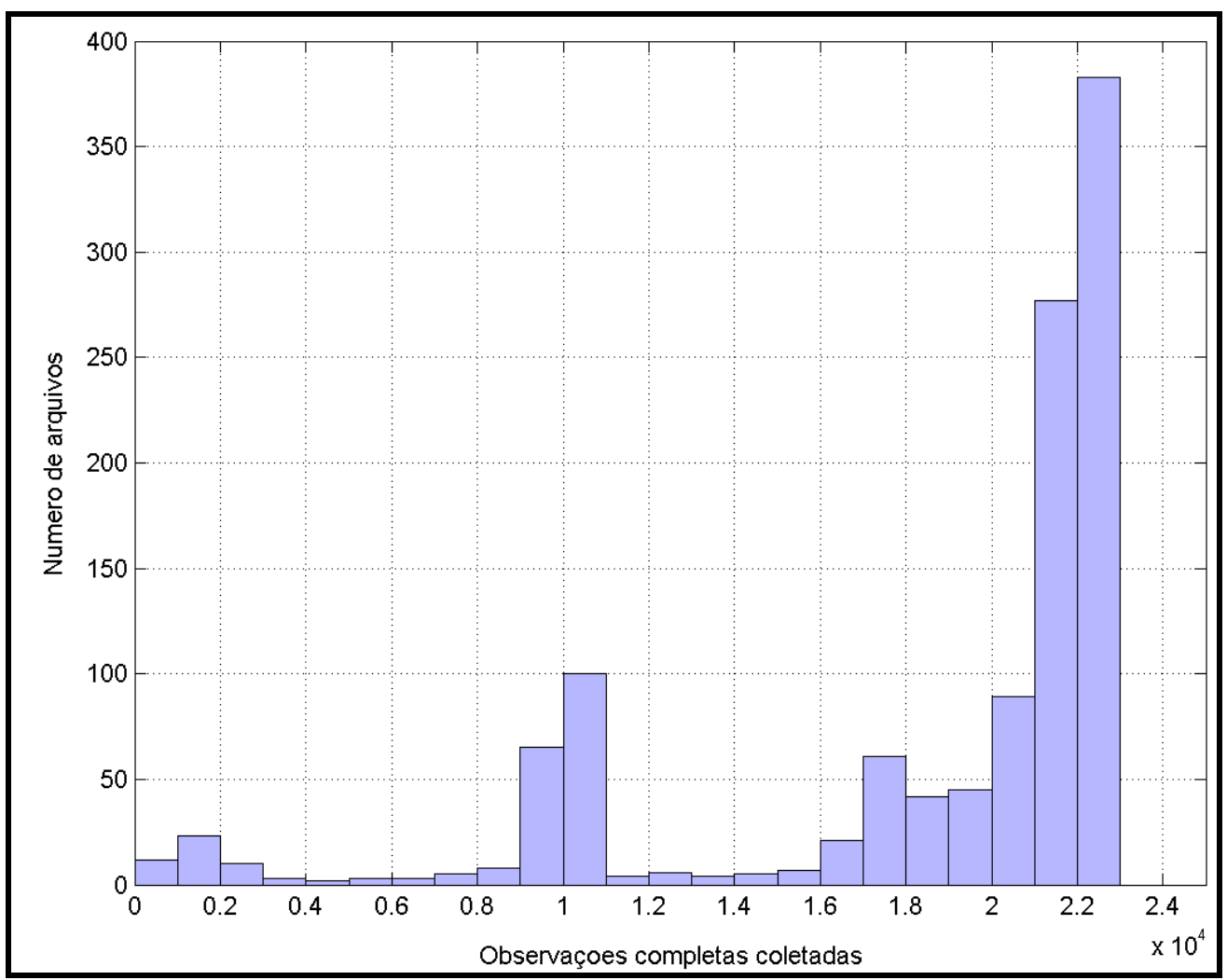

Figura 22: Histograma do número de observações coletadas por sessão no $2^{\circ}$ período.

\begin{tabular}{|c|c|c|}
\hline \multirow{2}{*}{$\begin{array}{c}\text { Observações coletadas } \\
\text { (em milhares) }\end{array}$} & \multicolumn{2}{|c|}{ № de arquivos (\% da amostra) } \\
\cline { 2 - 3 } & 1 período & 20 período \\
\hline $0 \vdash 5$ & $69(5,8 \%)$ & $56(4,7 \%)$ \\
\hline $5 \vdash 10$ & $112(9,4 \%)$ & $84(7,1 \%)$ \\
\hline $10 \vdash 15$ & $72(6,1 \%)$ & $119(10,1 \%)$ \\
\hline $15 \vdash 20$ & $178(15,0 \%)$ & $176(14,9 \%)$ \\
\hline$>20$ & $755(63,7 \%)$ & $749(63,3 \%)$ \\
\hline
\end{tabular}

Quadro 4 - Total de observações coletadas por sessão

Levando-se em consideração que cada arquivo continha 12 horas de observação, a uma taxa de coleta de 15 segundos, tem-se um total de 2880 épocas. Estimando-se como tendo em média nove satélites sendo rastreados continuamente em cada época, tem-se, teoricamente, um total de 25920 observações que poderiam ser coletadas em condições ideais. O número médio de observações coletadas para o $1^{\circ}$ período foi de 18374 ( $70,9 \%$ das possíveis), e para o $2^{\circ}$ período a média de observações coletadas foi de 18404 ( $71,0 \%$ das possíveis). 


\subsubsection{PERDAS DE CICLOS}

O indicativo de perdas de ciclos traz a informação da existência de obstruções que ocorreram durante o rastreio e que podem afetar a resolução das ambigüidades, acarretando em uma incerteza da coordenada final.

Através do Quadro 5 e dos histogramas (Figuras 23 e 24), é possível quantificar o número de perdas de ciclos sofridas pela estação. Deve-se considerar, nas Figuras 23 e 24, que a escala no eixo das abscissas é diferente.

\begin{tabular}{|c|c|c|}
\hline \multirow{2}{*}{$\begin{array}{l}\text { Perdas de ciclos } \\
\text { (épocas) }\end{array}$} & \multicolumn{2}{|c|}{ № de arquivos (\% da amostra) } \\
\hline & 1ํo período & $2^{\circ}$ período \\
\hline $0 \vdash 10$ & $32(2,7 \%)$ & $39(3,3 \%)$ \\
\hline $10 \vdash 20$ & $47(4,0 \%)$ & $158(13,3 \%)$ \\
\hline $20 \vdash 30$ & $245(20,7 \%)$ & $513(43,3 \%)$ \\
\hline $30 \vdash 40$ & $284(23,9 \%)$ & $289(24,4 \%)$ \\
\hline $40 \vdash 50$ & $187(15,8 \%)$ & $77(6,5 \%)$ \\
\hline $50 \vdash 60$ & $96(8,1 \%)$ & $34(2,9 \%)$ \\
\hline $60 \vdash 70$ & $48(4,0 \%)$ & $21(1,8 \%)$ \\
\hline $70 \vdash 80$ & $45(3,8 \%)$ & $15(1,3 \%)$ \\
\hline $80 \vdash 90$ & $42(3,5 \%)$ & $9(0,8 \%)$ \\
\hline $90 \vdash 100$ & $21(1,8 \%)$ & $6(0,5 \%)$ \\
\hline $100 \vdash 120$ & $45(3,8 \%)$ & $10(0,8 \%)$ \\
\hline $120 \vdash 140$ & $23(1,9 \%)$ & $4(0,3 \%)$ \\
\hline $140 \vdash 160$ & $30(2,5 \%)$ & $4(0,3 \%)$ \\
\hline $160 \vdash 180$ & $21(1,8 \%)$ & $1(0,1 \%)$ \\
\hline $180 \vdash 200$ & $8(0,7 \%)$ & $0(0,0 \%)$ \\
\hline$>200$ & $12(1,0 \%)$ & $4(0,3 \%)$ \\
\hline
\end{tabular}

Quadro 5 - Valores de perdas de ciclos 


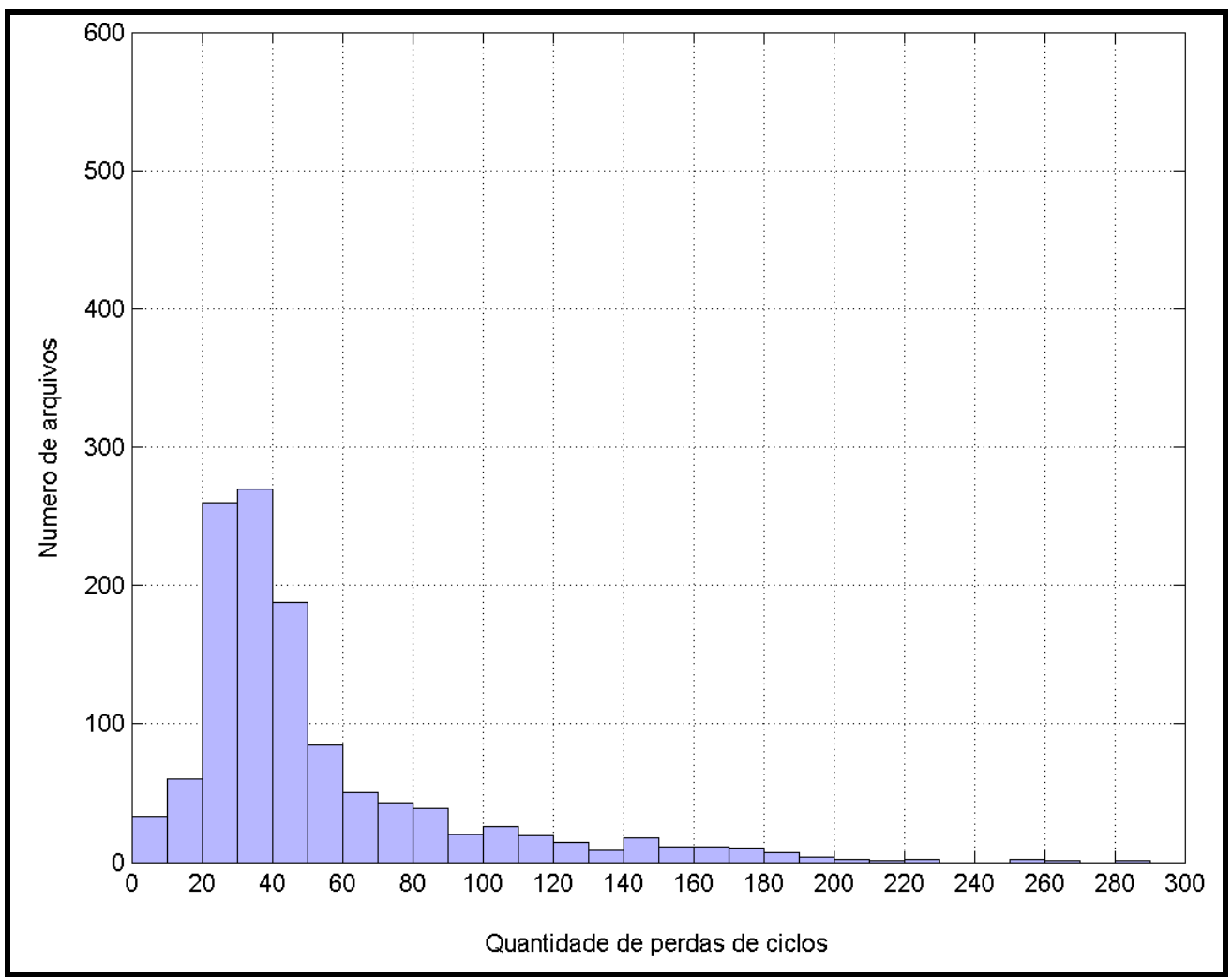

Figura 23: Histograma do número de perdas de ciclos por sessão no $1^{\circ}$ período.

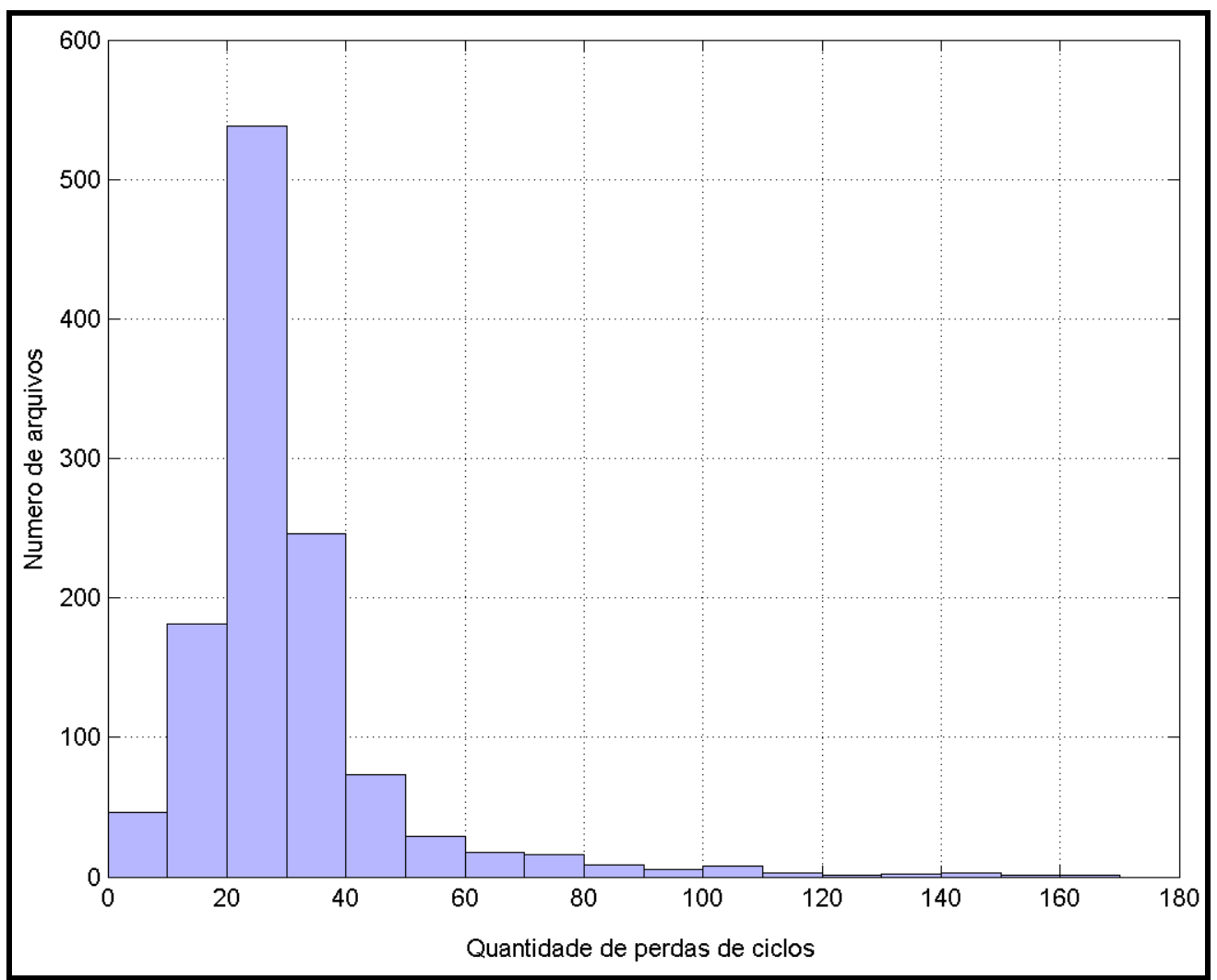

Figura 24: Histograma do número de perdas de ciclos por sessão no $2^{\underline{0}}$ período. 
Analisando-se os resultados apresentados observa-se que o número de perdas calculadas, em média, para o $1^{0}$ período foi de 52,5. Considerando que temos em média 18374 observações coletadas para o $1^{\circ}$ período, temos uma perda a cada 456 observações, ou seja, uma perda a cada 13 minutos de coleta aproximadamente. Para o $2^{\circ}$ período a média de perdas calculadas foi de 30,9 Como para o $2^{\circ}$ período temos uma média de 18404 observações coletadas, ocorre uma perda a cada 596 observações completas, resultando em uma perda a cada 16,5 minutos de coleta.

Analisando-se o número de arquivos processados, têm-se os seguintes resultados: no $1^{\circ}$ período, de 1186 arquivos analisados, $1047(88,3 \%)$ continham até 100 perdas e no $2^{\circ}$ período, dos 1184 arquivos processados, 1164 (98,3\%) possuíam menos de 100 perdas de ciclos. Pode-se comprovar estas informações consultando-se o Quadro 5.

\subsubsection{MULTICAMINHO}

Como descrito no item 2.10.1.3, o multicaminho é resultante do local em que a estação está localizada. A partir dos indicativos MP1 e MP2, calculados pelo TEQC, podemos quantificar o multicaminho que afeta a estação. Vale ressaltar, que os indicativos de multicaminho calculados pelo TEQC, também representam a qualidade do conjunto receptor/antena.

Os Quadros 6 e 7 apresentam a freqüência de ocorrência do efeito de multicaminho nas portadoras L1 e L2. 


\begin{tabular}{|c|c|c|}
\hline \multirow{2}{*}{$\begin{array}{c}\text { MP1 } \\
(\mathbf{c m})\end{array}$} & \multicolumn{2}{|c|}{ № de arquivos (\% da amostra) } \\
\cline { 2 - 3 } & 1ㅇ período & 2o período \\
\hline $0 \vdash 10$ & $214(18,0 \%)$ & $262(22,1 \%)$ \\
\hline $10 \vdash 20$ & $90(7,6 \%)$ & $71(6,0 \%)$ \\
\hline $20 \vdash 30$ & $691(58,3 \%)$ & $645(54,5 \%)$ \\
\hline $30 \vdash 40$ & $157(13,2 \%)$ & $172(14,5 \%)$ \\
\hline $40 \vdash 50$ & $5(0,4 \%)$ & $5(0,4 \%)$ \\
\hline $50 \vdash 60$ & $9(0,8 \%)$ & $9(0,8 \%)$ \\
\hline $60 \vdash 70$ & $20(1,7 \%)$ & $16(1,4 \%)$ \\
\hline $70 \vdash 80$ & $0(0,0 \%)$ & $4(0,3 \%)$ \\
\hline
\end{tabular}

Quadro 6 - Valores calculados para MP1

\begin{tabular}{|c|c|c|}
\hline \multirow{2}{*}{$\begin{array}{c}\text { MP2 } \\
(\mathbf{c m})\end{array}$} & \multicolumn{2}{|c|}{ № de arquivos (\% da amostra) } \\
\cline { 2 - 3 } & $\mathbf{1}$ o período & 20 período \\
\hline$<60$ & $11(0,9 \%)$ & $17(1,4 \%)$ \\
\hline $60 \vdash 70$ & $29(2,4 \%)$ & $18(1,5 \%)$ \\
\hline $70 \vdash 80$ & $84(7,1 \%)$ & $77(6,5 \%)$ \\
\hline $80 \vdash 90$ & $539(45,4 \%)$ & $299(25,3 \%)$ \\
\hline $90 \vdash 100$ & $229(19,3 \%)$ & $357(30,2 \%)$ \\
\hline $100 \vdash 110$ & $92(7,8 \%)$ & $205(17,3 \%)$ \\
\hline $110 \vdash 120$ & $96(8,1 \%)$ & $80(6,8 \%)$ \\
\hline $120 \vdash 130$ & $48(4,0 \%)$ & $66(5,6 \%)$ \\
\hline $130 \vdash 140$ & $17(1,4 \%)$ & $24(2,0 \%)$ \\
\hline $140 \vdash 150$ & $6(0,5 \%)$ & $6(0,5 \%)$ \\
\hline $150 \vdash 250$ & $5(0,4 \%)$ & $4(0,3 \%)$ \\
\hline$>250$ & $30(2,5 \%)$ & $31(2,6 \%)$ \\
\hline
\end{tabular}


No Quadro 6, referente a MP1, é possível observar que:

- no $1^{\text {o }}$ período, dos 1186 arquivos analisados, 1152 (97,1\%) apresentaram multicaminho em L1 menor que $40 \mathrm{~cm}$, sendo que, o MP1 médio para o período foi de $24 \mathrm{~cm}$ com desvio padrão de $10 \mathrm{~cm}$;

- no $2^{\circ}$ período, de 1184 arquivos processados, 1150 (97,1\%) possuíam MP1 menor que $40 \mathrm{~cm}$, com um valor médio de $24 \mathrm{~cm}$ e desvio de 11 $\mathrm{cm}$.

Analisando-se o Quadro 7, pode-se verificar que para o efeito de multicaminho em L2, temos:

- no $1^{\circ}$ período $91,1 \%$ dos dados (1080 de 1186), ficaram abaixo de 120 $\mathrm{cm}$, obtendo média de $101 \mathrm{~cm}$ e desvio de $43 \mathrm{~cm}$;

- para o 2ำ período de 1184 arquivos, 1053 (88,9\%) ficaram abaixo dos $120 \mathrm{~cm}$, sendo que a média calculada para o período foi de $105 \mathrm{~cm}$ com desvio padrão de $44 \mathrm{~cm}$.

O Quadro 8 apresenta os valores calculados do $1^{\circ}$ quartil, da mediana, do $3^{\circ}$ quartil, dos limites inferior e superior e dos valores de máximo e mínimo utilizados para detecção e eliminação de outliers. As Figuras 25 e 26 trazem os boxplots que representam graficamente os valores apresentados no Quadro 8. Em todos os boxplots, apresentados nesta pesquisa, os pontos vermelhos, que estão além de LI e LS, são a representação dos pontos que foram eliminados e que, encontram-se mais próximos aos limites de corte (LI e LS).

\begin{tabular}{|c|c|c|c|c|}
\hline \multirow{2}{*}{ Indicadores } & \multicolumn{2}{|c|}{ MP1 (m) } & \multicolumn{2}{|c|}{ MP2 (m) } \\
\hline & 1으. & $2^{\circ}$ per. & $1^{\circ}$ per. & $2^{\circ}$ per. \\
\hline Mínimo & 0,00 & 0,00 & 0,00 & 0,00 \\
\hline Máximo & 0,71 & 0,80 & 3,86 & 3,86 \\
\hline 1ㅇQ Quartil & 0,19 & 0,12 & 0,85 & 0,88 \\
\hline Mediana & 0,27 & 0,28 & 0,89 & 0,95 \\
\hline 3으artil & 0,29 & 0,30 & 1,00 & 1,05 \\
\hline Limite Inferior & 0,04 & $-0,15$ & 0,63 & 0,63 \\
\hline Limite Superior & 0,44 & 0,57 & 1,23 & 1,31 \\
\hline
\end{tabular}

Quadro 8 - Valores calculados para eliminação de outliers em MP1 e MP2 


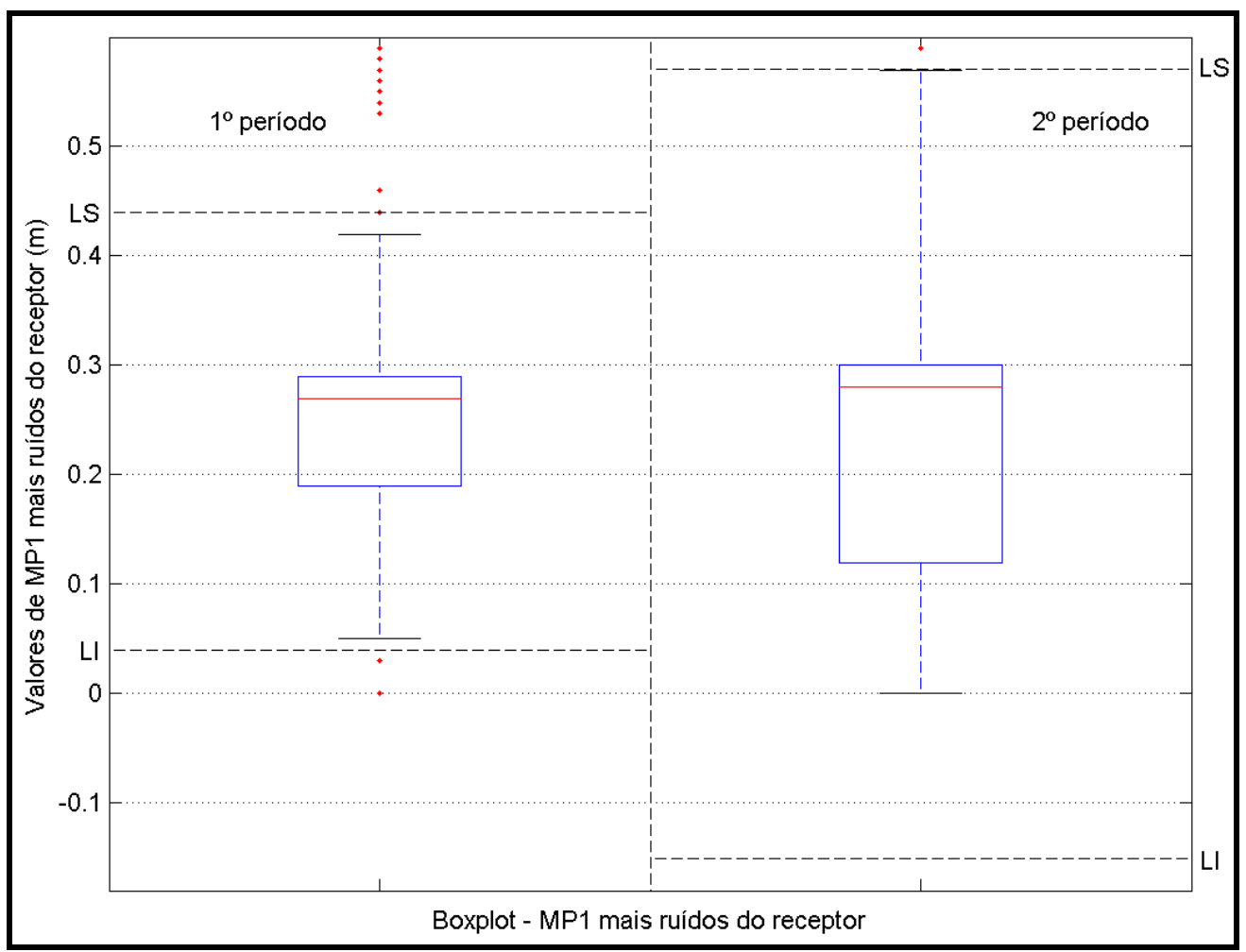

Figura 25: Boxplots para MP1 para os dois períodos.

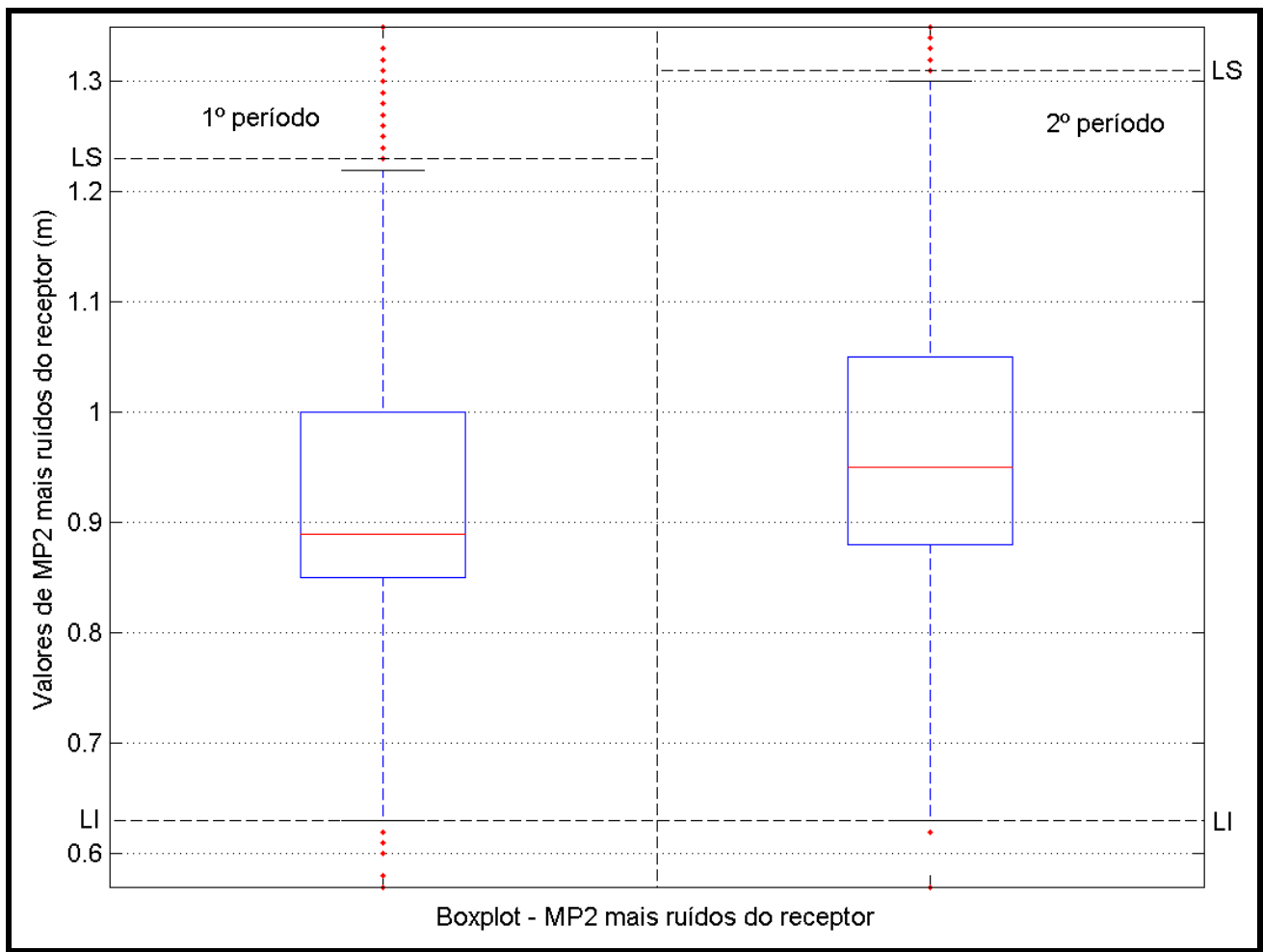

Figura 26: Boxplots para MP2 para os dois períodos.

Na análise gráfica (Figuras 27 e 28) dos valores calculados para multicaminho em L1 (MP1) e do multicaminho em L2 (MP2), foi aplicada a técnica de filtragem 
descrita no item 3.5. Como já dito, a filtragem foi utilizada para eliminar possíveis outliers, e tem por objetivo apenas facilitar a visualização de possíveis movimentos de tendência na representação gráfica. Os dois indicativos (MP1 e MP2), para um mesmo período, estão reproduzidos no mesmo gráfico, também com a finalidade de facilitar a visualização de possíveis movimentos que possam ser detectados em ambos os indicativos.

As falhas na série de dados, observadas no primeiro semestre dos anos de 2002, 2003 e 2004, e no segundo semestre de 2005, ocorreram por problemas técnicos que afetaram a estação e acarretaram na falta de coleta de dados nestes períodos.

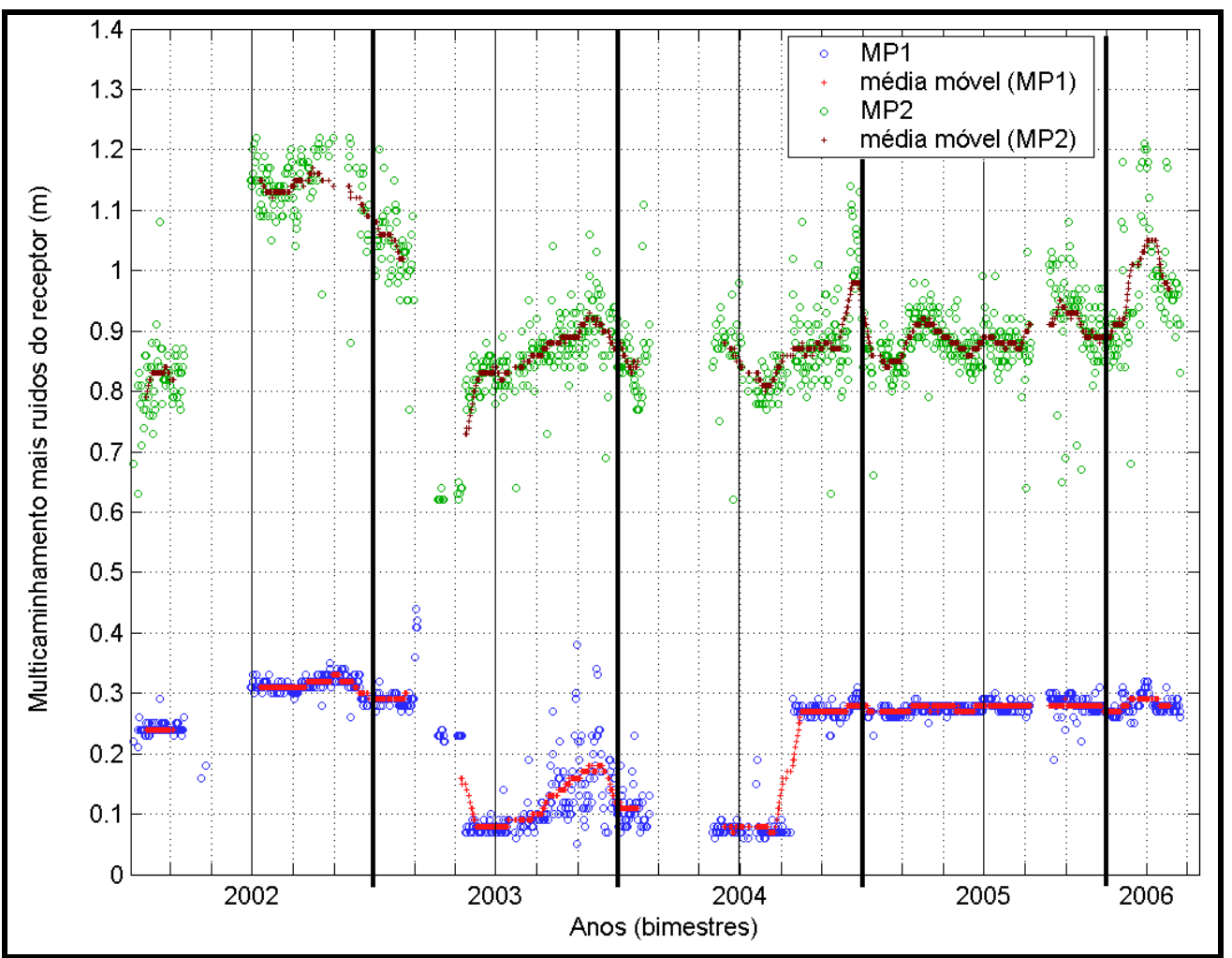

Figura 27: Gráfico dos valores calculados para MP1 e MP2 no 1ํ período, após filtragem 


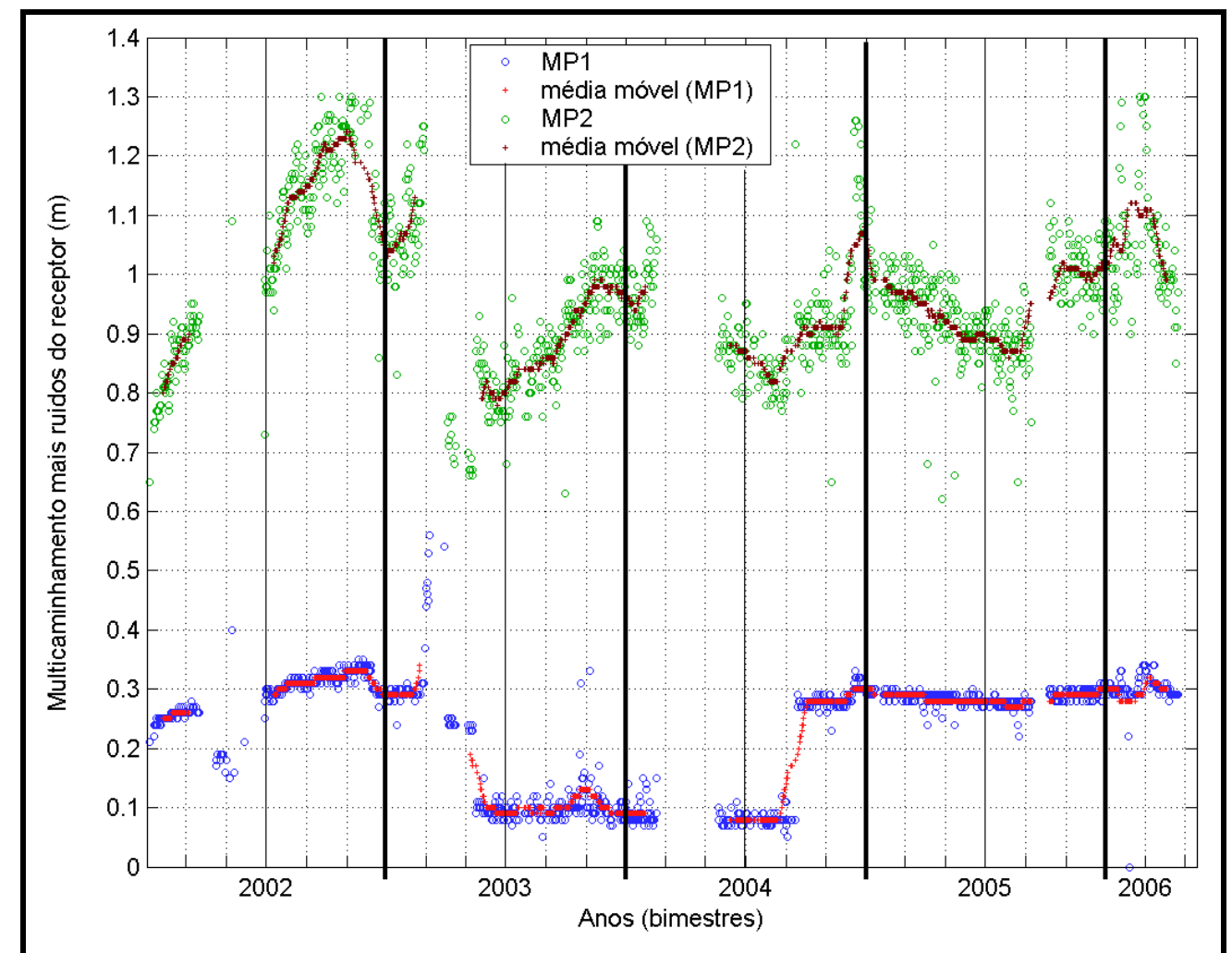

Figura 28: Gráfico dos valores calculados para MP1 e MP2 no $2^{0}$ período, após filtragem

Pode-se observar pelas Figuras 27 e 28 que os valores calculados para cada um dos indicadores (MP1 e MP2) mantiveram-se coerentes, apresentando o mesmo comportamento para ambos os períodos. O que chama mais atenção é o comportamento apresentado por MP1, detectado nos dois períodos, pois o valor de multicaminho geralmente sofre mudanças suaves, diferente do que acontece entre os anos de 2003 e 2004, onde se pode observar mudanças bruscas. O histórico da estação deve ser pesquisado para se tentar identificar a causa do problema, pois, neste trabalho, não se chegou a uma conclusão através da análise dos indicativos estudados. Além disso, observando a média móvel para MP2, principalmente no $2^{\circ}$ período (Figura 28), fica aparente um possível movimento cíclico, de decréscimo para o primeiro semestre (de jan. a jun.) e de crescimento para o segundo (de jul. a dez.), mas este mesmo movimento não é verificado em MP1. Outras pesquisas devem ser feitas a fim de se determinar o causador desta variação.

Utilizando como parâmetro de comparação o trabalho realizado por Fazan, 2002, que calculou os valores médios de MP1 e MP2 para cada uma das estações da RBMC (na época eram 15 estações), verifica-se que os índices MP1 $(24 \mathrm{~cm})$ e MP2 $(103 \mathrm{~cm})$ calculados para a estação NEIA, neste trabalho, estão bem próximos 
à média calculada para todas as estações pesquisadas por Fazan, que apresentaram multicaminho médio em L1 de $29 \mathrm{~cm}$ e em L2 de $88 \mathrm{~cm}$. Atualmente, algumas estações possuem receptores mais modernos que ajudam na redução deste efeito, mas, na época em que Fazan realizou sua pesquisa, todos os receptores/antenas eram equivalentes ao utilizado atualmente pela estação NEIA.

\subsection{PROCESSAMENTO PRELIMINAR UTILIZANDO QUATRO DIFERENTES SERVIÇOS DE PROCESSAMENTO ON-LINE}

Nesta etapa da pesquisa foi realizado o processamento dos dados utilizando alguns serviços de processamento on-line, disponíveis gratuitamente na internet. Esta foi uma maneira de processar os dados enquanto o programa Bernese V5.0 era estudado para ser utilizado.

O objetivo deste primeiro processamento foi o de analisar, de forma preliminar, os resultados de processamento dos dados coletados pela estação NEIA, realizados pelos serviços disponibilizados pelas seguintes agências e instituições:

- CSRS - PPP (Canadian Spatial Reference System - Precise Point Positioning) - Canadian Geodetic Service of Natural Resources Canada - Serviço Canadense;

- AUSPOS (The Australiian Surveying and Land Information Group's Online GPS Processing Service) - Geoscience Australia - Serviço Australiano;

- SCOUT (Scripps Coordinate Update Tool) - SOPAC (Scripps Orbit and Permanent Array Center) - Serviço Norte-Americano e;

- AG (Auto Gipsy) - JPL (Jet Propulsion Laboratory, California Institute of Technology) - Serviço Norte-Americano.

Os dados processados foram divididos em 3 grupos: dos dias julianos 74 ao 80 (15/03/2002 a 21/03/2002 - Semana 1), 180 ao 186 (29/06/2003 a 05/07/2003 Semana 2) e 312 ao 318 (08/11/2003 a 14/11/2003 - Semana 3). Estes dias foram escolhidos para se comparar os resultados em épocas de menor (meses de junho e 
julho) e maior (meses de março e novembro) atividade da ionosfera. Mais detalhes sobre a ionosfera podem ser encontrados em Camargo, 1999 e Fonseca Jr., 2002.

Foram utilizados na Semana 1 dados de 2002, e nas Semanas 2 e 3 dados de 2003, pois foram as seqüências de dados mais completas encontradas para o período previamente definido.

Este primeiro processamento teve como objetivo servir como uma préavaliação para verificação de qual serviço apresentaria os melhores resultados, para que posteriormente fosse utilizado para processar um número maior de dados.

As particularidades de cada ferramenta de processamento estão descritas no item 3.3.3.

Todos os resultados aqui apresentados estão de acordo com o controle de qualidade sugerido por cada serviço.

\subsubsection{ENVIO e PROCESSAMENTO dos ARQUIVOS}

Depois de revisadas as informações da altura e do tipo da antena contidas no cabeçalho de todos os arquivos, os mesmos, foram enviados para cada um dos serviços.

Como já dito anteriormente, o único serviço que realiza "Posicionamento Preciso por Ponto" é o CSRS - PPP, onde o arquivo RINEX recebido passa por uma filtragem para eliminação de observações ruins, e por um processamento, gerando a coordenada final. Nos demais serviços o processamento realizado é no modo relativo, utilizando-se de estações do IGS, que estejam próximas à estação enviada pelo usuário, para determinação de suas coordenadas.

A escolha das estações de referência é realizada automaticamente pelo próprio serviço, sem a intervenção do usuário. O AUSPOS utilizou as estações BRAZ (Brasília - Brasil), LPGS (La Plata - Argentina) e UNSA (Salta - Argentina), enquanto o SCOUT utilizou as estações BRAZ (Brasília - Brasil), CHPI (Cachoeira Paulista - Brasil) e LPGS (La Plata - Argentina). O serviço AG-JPL não fornece o nome das estações utilizadas. Na tabela 4.1 é possível verificar o comprimento das linhas de base utilizadas. 
Tabela 4.1 - Comprimento das linhas de base utilizadas

\begin{tabular}{cc}
\hline Linha de base & Comprimento da linha $(\mathbf{k m})$ \\
\hline BRAZ - NEIA & 1003 \\
CHPI - NEIA & 395 \\
LPGS - NEIA & 1455 \\
UNSA - NEIA & 1760 \\
\hline
\end{tabular}

\subsubsection{RESULtAdos E ANÁlISES}

Após o processamento dos dados, o resultado gerado por cada serviço é enviado para o e-mail designado pelo usuário. Essa resposta pode chegar em poucos minutos, casos do CSRS-PPP e JPL, ou até demorar algumas horas, no caso do SCOUT e do AUSPOS.

No arquivo recebido, além de constarem as coordenadas calculadas da estação, são enviados os respectivos desvios padrão para cada componente: latitude, longitude e altura geométrica.

Com exceção do serviço SCOUT, todos os outros disponibilizam relatórios do processamento, indicando as operações realizadas.

A seguir, são apresentadas figuras contendo os gráficos de análise dos resultados realizados neste primeiro processamento, para todos os serviços, separadamente para latitude, longitude e altura geométrica.

Foram tomadas como referência as coordenadas da estação NEIA, calculadas pelo IBGE e referidas ao SIRGAS2000 (Sistema de Referência Geocêntrico para as Américas - época 2000.4), disponibilizadas no sítio do próprio Instituto. Essas coordenadas são (INSTITUTO BRASILEIRO DE GEOGRAFIA E ESTATÍSTICA, 2006):

$$
\begin{aligned}
& -\varphi=25^{\circ} 01^{\prime} 12,8615^{\prime \prime} \mathrm{S} \\
& -\lambda=47^{\circ} 55^{\prime} 29,8867^{\prime \prime} \mathrm{W} \\
& -\mathrm{h}=6,060 \mathrm{~m}
\end{aligned}
$$

Como as coordenadas da estação estão referidas ao SIRGAS2000 e os serviços geram resultados em ITRF2000, os mesmos podem ser comparados 
diretamente, sem necessidade de compatibilização, pois as realizações SIRGAS (Sistema de Referência Geocêntrico para as Américas) correspondem as densificações do ITRF (International Terrestrial Reference Frame) nas Américas (INSTITUTO BRASILEIRO DE GEOGRAFIA E ESTATÍSTICA, 2003).

\subsubsection{ANÁLISE DAS DIFERENÇAS DA SEMANA 1}

A seguir são apresentadas as Figuras 29, 30 e 31 indicando as diferenças de latitude, longitude e altura da estação NEIA, calculadas por cada serviço. Deve-se observar que os gráficos não estão representados na mesma escala (eixo y), para evitar perda de detalhes.

O Quadro 9 apresenta as médias $(\overline{\mathrm{x}})$ das diferenças para latitude, longitude e altura, e seus respectivos desvios padrão $(\sigma)$, para cada serviço utilizado. Deve-se observar que, os valores em azul representam as menores diferenças encontradas para cada componente, enquanto os valores em vermelho representam as maiores diferenças.

A falta de resultados no serviço do JPL para os dias 74 e 77 se devem ao fato de não ter havido resposta ao envio do arquivo, apesar de o arquivo ter sido enviado por 4 vezes. Como esses dados foram processados pelos outros serviços, pode-se concluir que não foi um problema no arquivo de observações. 


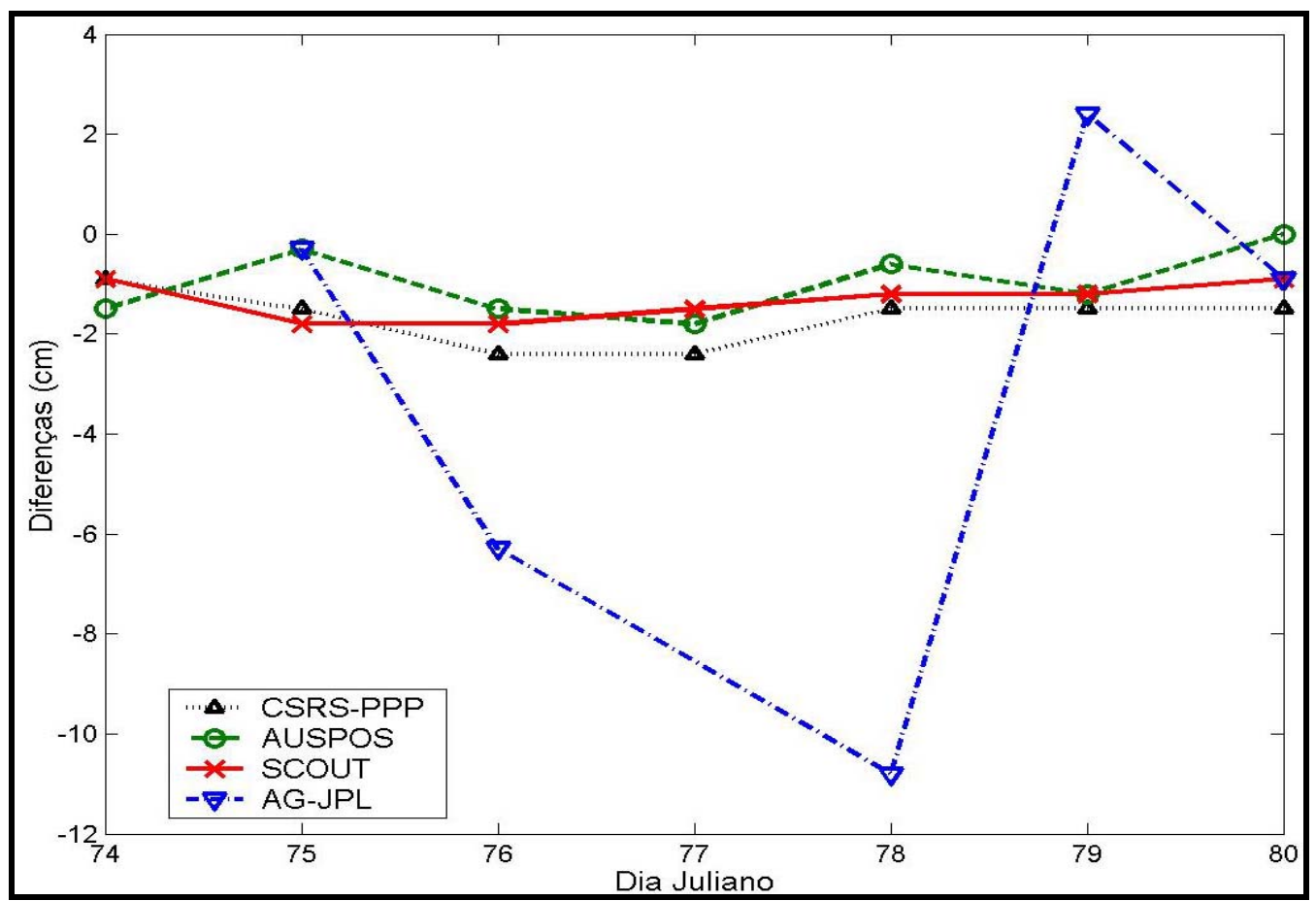

Figura 29: Gráfico das diferenças em latitude na semana1

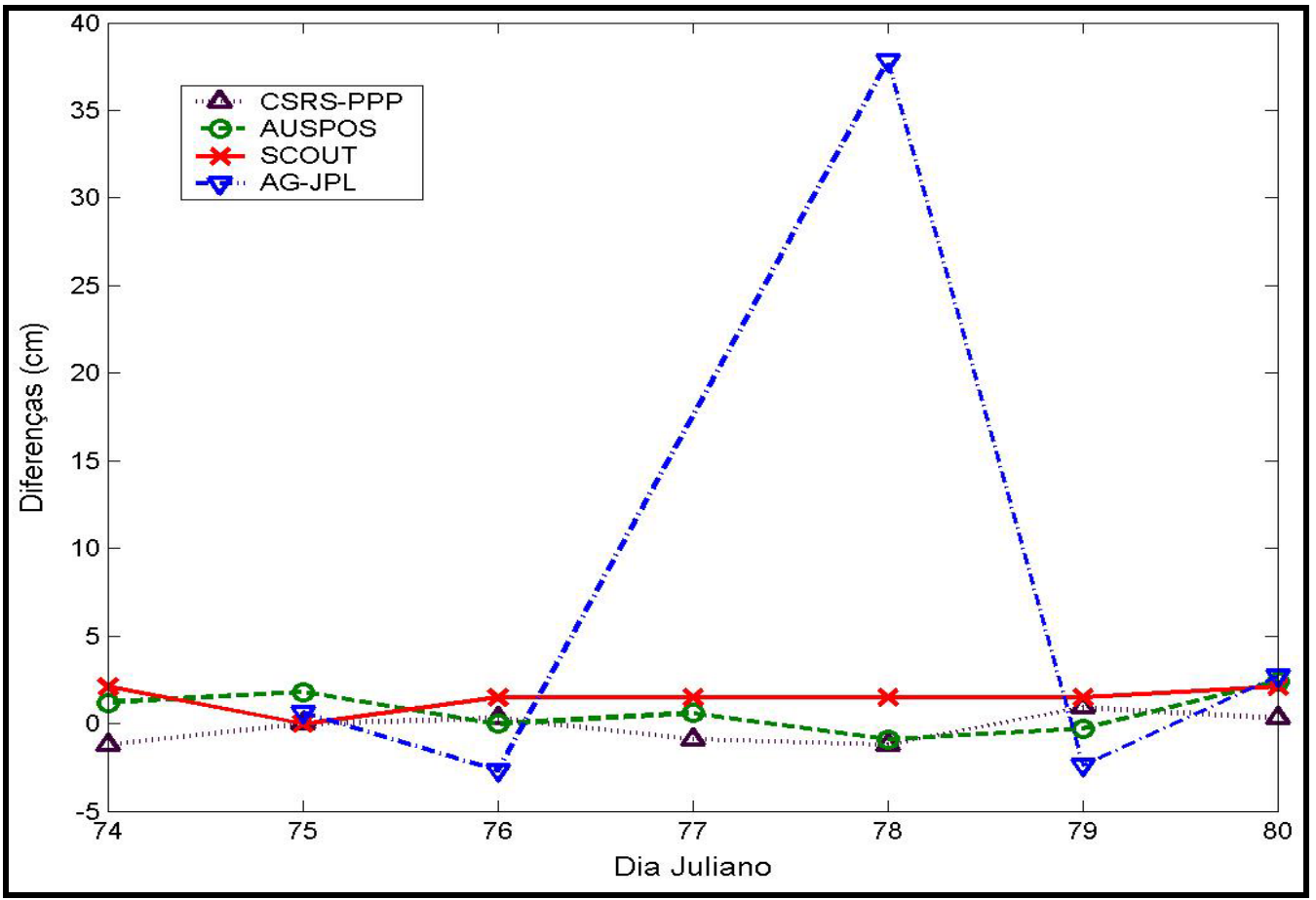

Figura 30: Gráfico das diferenças em longitude na semana1 


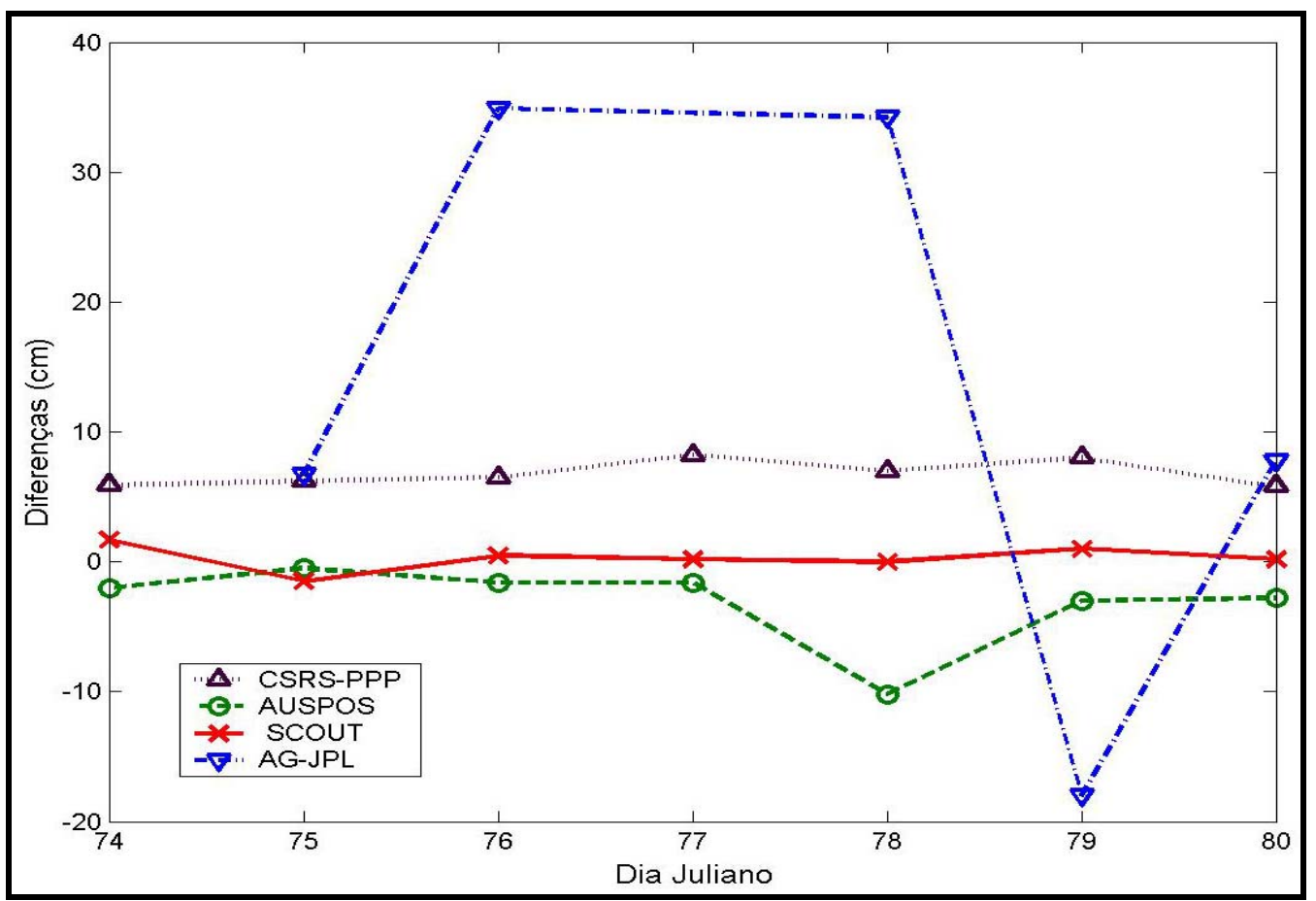

Figura 31: Gráfico das diferenças em altura geométrica na semana1

\begin{tabular}{|c|c|c|c|}
\hline \multirow{2}{*}{ Serviço } & $\Delta$ Lat(cm) & $\Delta$ Long(cm) & $\Delta \mathbf{h}(\mathbf{c m})$ \\
\cline { 2 - 4 } & $\overline{\mathrm{x}} \pm \sigma$ & $\overline{\mathrm{x}} \pm \sigma$ & $\overline{\mathrm{x}} \pm \sigma$ \\
\hline CSRS-PPP & $-1,7 \pm 0,5$ & $-0,3 \pm 0,8$ & $6,8 \pm 1,0$ \\
\hline AUSPOS & $-1,0 \pm 0,7$ & $0,7 \pm 1,2$ & $-3,1 \pm 3,2$ \\
\hline SCOUT & $-1,3 \pm 0,4$ & $1,5 \pm 0,7$ & $0,3 \pm 1,0$ \\
\hline AG-JPL & $-3,2 \pm 5,3$ & $7,2 \pm 17,3$ & $13,1 \pm 22,1$ \\
\hline
\end{tabular}

Quadro 9 - Média e desvio padrão das diferenças da semana1

Observando-se as Figuras 29, 30 e 31 e o Quadro 9 da Semana 1, verifica-se que o serviço oferecido pelo JPL foi o que apresentou maiores diferenças em relação às coordenadas fiduciais da estação NEIA. Chama à atenção, na Figura 31, as diferenças encontradas pelo CSRS-PPP em altura, o que aparenta ser um erro sistemático, e a diferença obtida para altura pelo AUSPOS no dia 78, próxima dos 10 $\mathrm{cm}$. 


\subsubsection{ANÁLISE DAS DIFERENÇAS DA SEMANA 2}

Na seqüência são apresentadas as figuras 32, 33 e 34 indicando as diferenças de latitude, longitude e altura da estação NEIA, calculadas por cada uma das ferramentas on-line.

O Quadro 10 apresenta as médias $(\bar{x})$ das diferenças para latitude, longitude e altura, e seu respectivo desvio padrão $(\sigma)$, para cada serviço.

A falta de resultados no serviço do JPL nos dias 180, 181 e 185, se deve a mesma causa apontada anteriormente na seção (4.2.4.1).

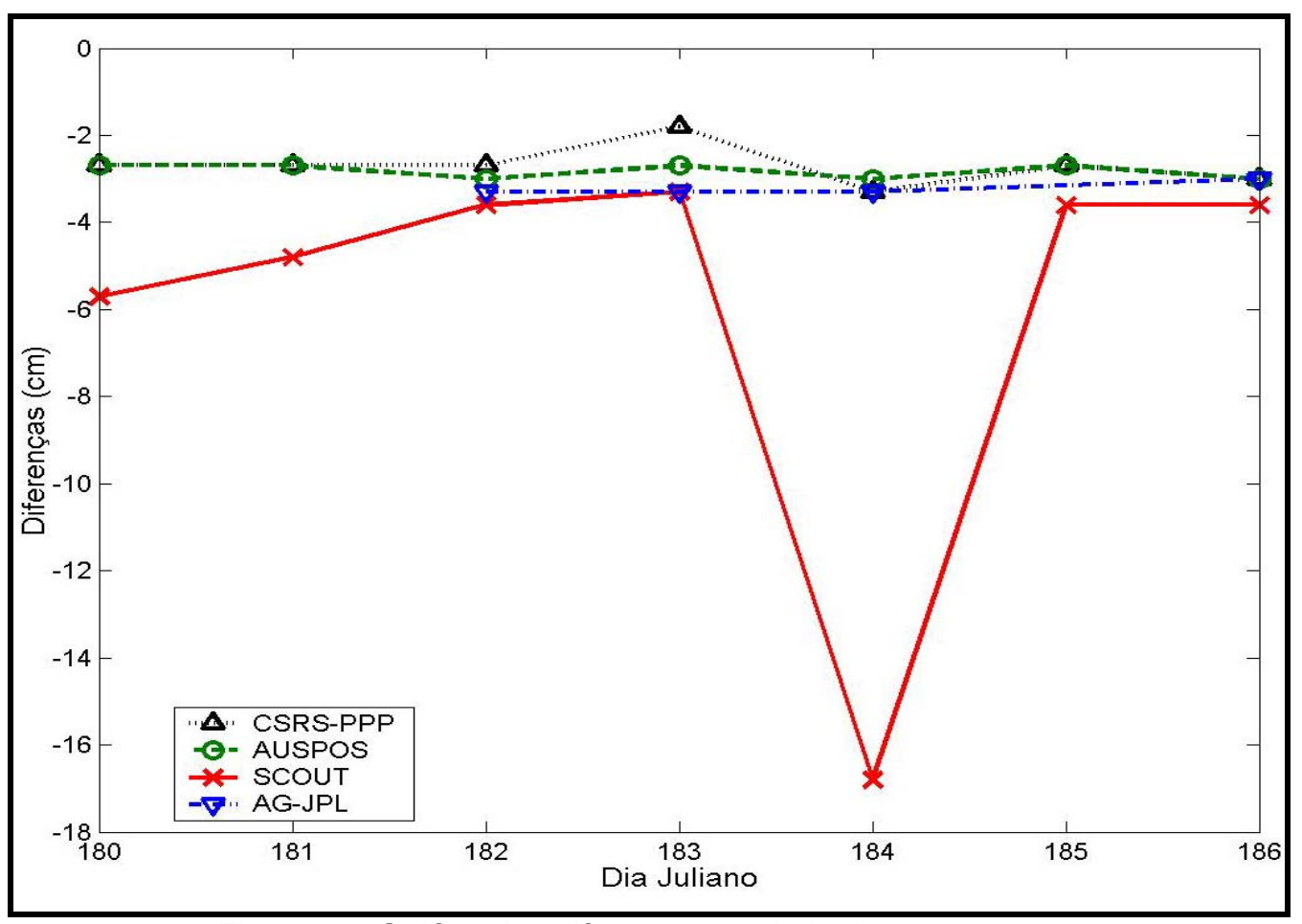

Figura 32: Gráfico das diferenças em latitude na semana2. 


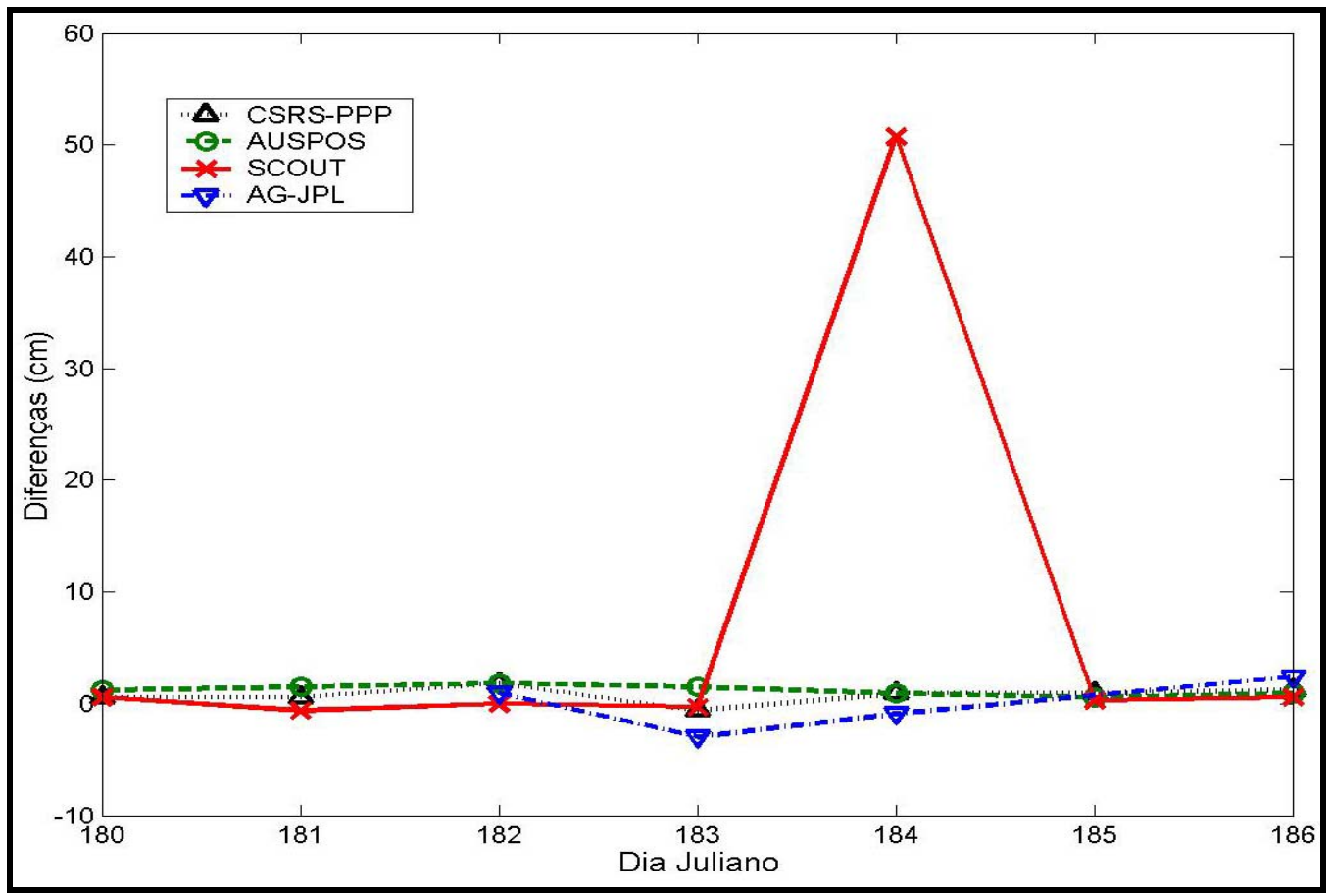

Figura 33: Gráfico das diferenças em longitude na semana2.

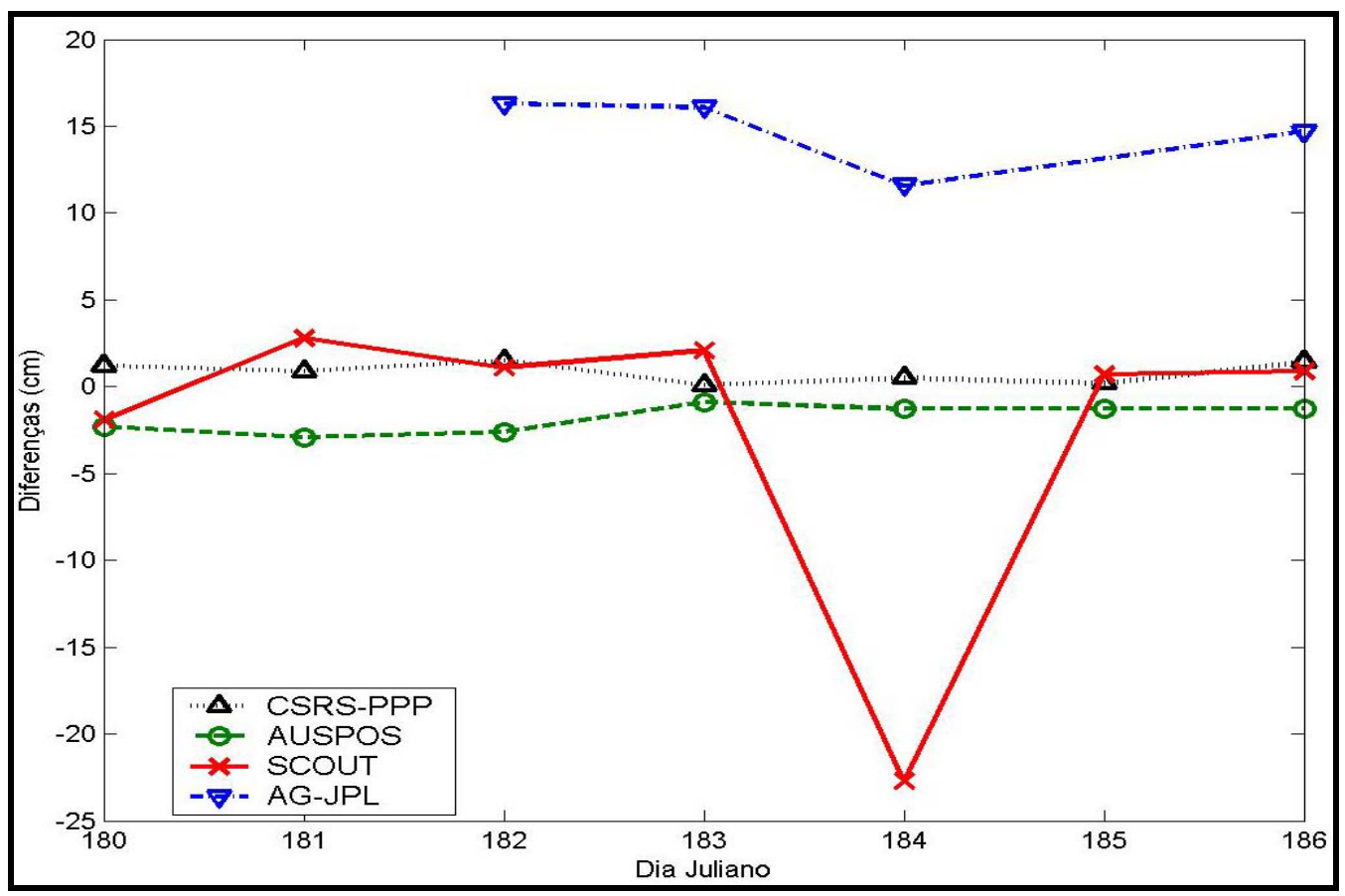

Figura 34: Gráfico das diferenças em altura geométrica na semana2. 


\begin{tabular}{|c|c|c|c|}
\hline \multirow{2}{*}{ Serviço } & $\Delta$ Lat(cm) & $\Delta$ Long(cm) & $\Delta \mathbf{h}(\mathbf{c m})$ \\
\cline { 2 - 4 } & $\overline{\mathrm{x}} \pm \sigma$ & $\overline{\mathrm{x}} \pm \sigma$ & $\overline{\mathbf{x}} \pm \sigma$ \\
\hline CSRS-PPP & $-2,7 \pm 0,5$ & $0,8 \pm 0,7$ & $0,8 \pm 0,6$ \\
\hline AUSPOS & $-2,8 \pm 0,2$ & $1,2 \pm 0,4$ & $-1,8 \pm 0,8$ \\
\hline SCOUT & $-5,9 \pm 4,9$ & $7,3 \pm 19,1$ & $-2,4 \pm 9,1$ \\
\hline AG-JPL & $-3,2 \pm 0,1$ & $-0,2 \pm 2,3$ & $14,7 \pm 2,2$ \\
\hline
\end{tabular}

Quadro 10 - Média e desvio padrão das diferenças da semana2

Analisando-se as Figuras 32, 33 e 34, e o Quadro da Semana 2, pode-se observar que o serviço SCOUT ao processar o arquivo do dia 184, gerou coordenadas com diferenças de até $50 \mathrm{~cm}$ em relação às coordenadas conhecidas da estação. Pode-se visualizar também a diferença em altura calculada pelo JPL, que pode indicar um erro de origem sistemática.

\subsubsection{ANÁLISE DAS DIFERENÇAS DA SEMANA 3}

A seguir são apresentadas as Figuras 35, 36 e 37 indicando as diferenças de latitude, longitude e altura geométrica da estação NEIA, calculadas por cada serviço de processamento on-line.

O Quadro 11 apresenta as médias $(\overline{\mathbf{x}})$ das diferenças para latitude, longitude e altura, e seu respectivo desvio padrão $(\sigma)$, para cada serviço. 


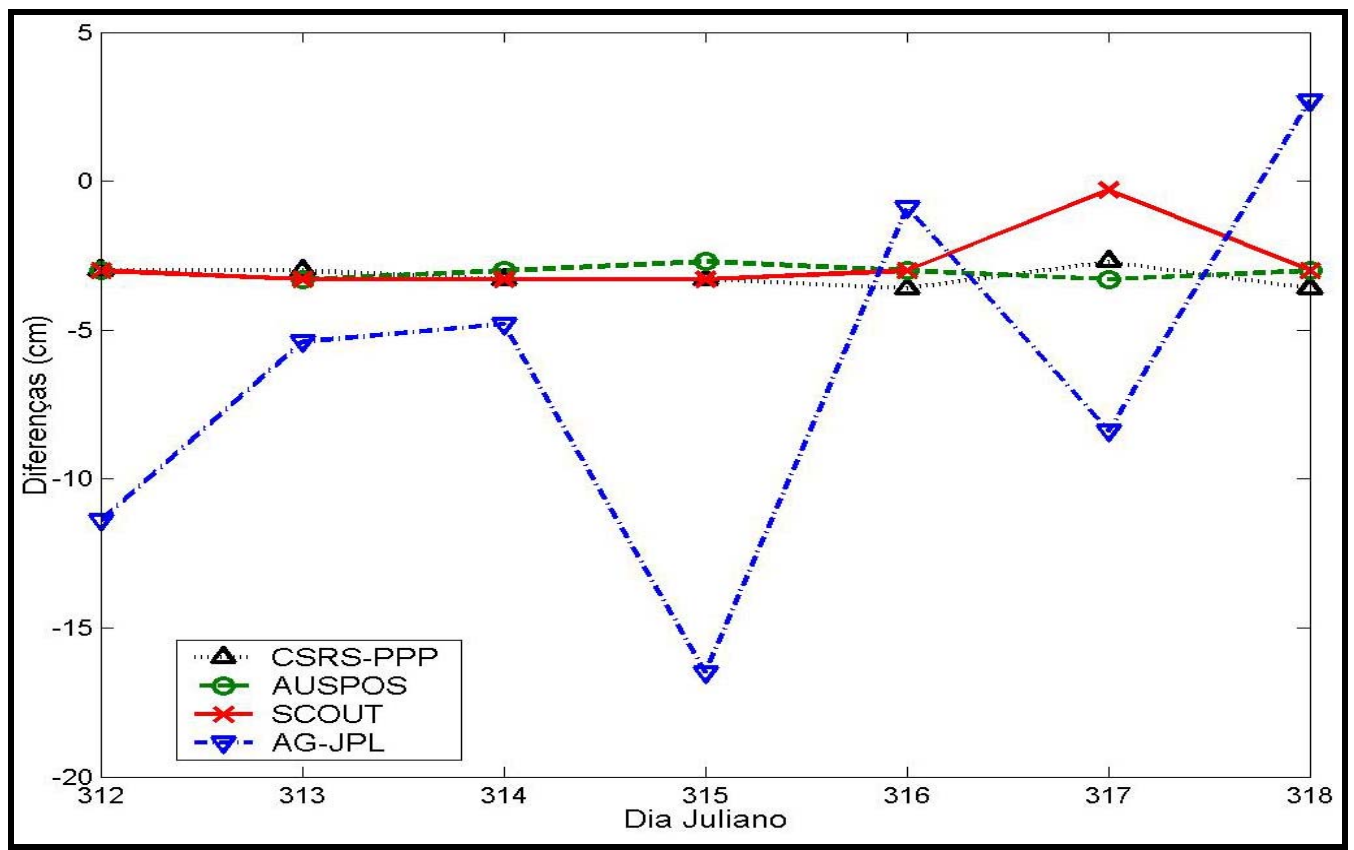

Figura 35: Gráfico das diferenças em latitude na semana3.

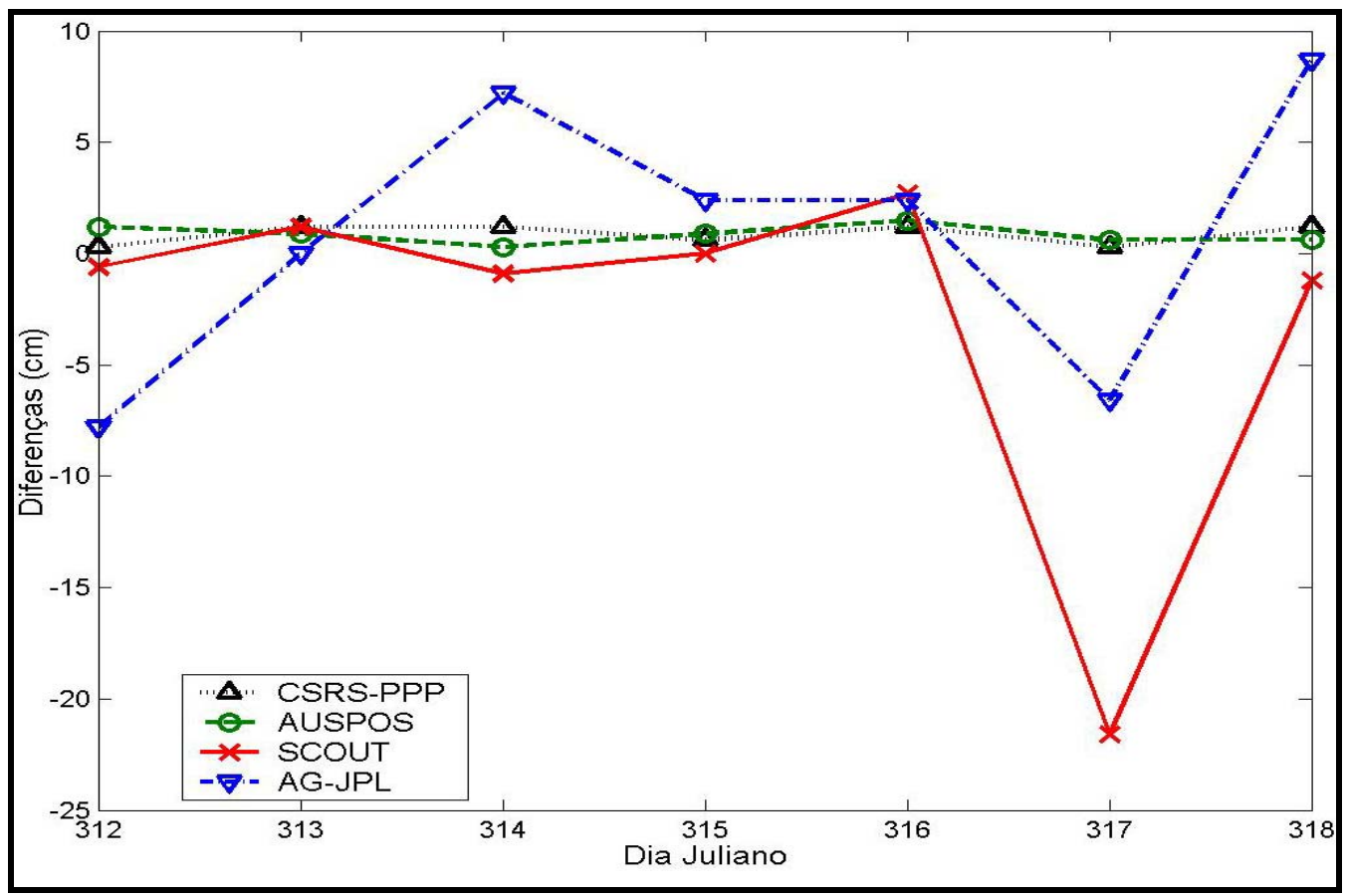

Figura 36: Gráfico das diferenças em longitude na semana3. 


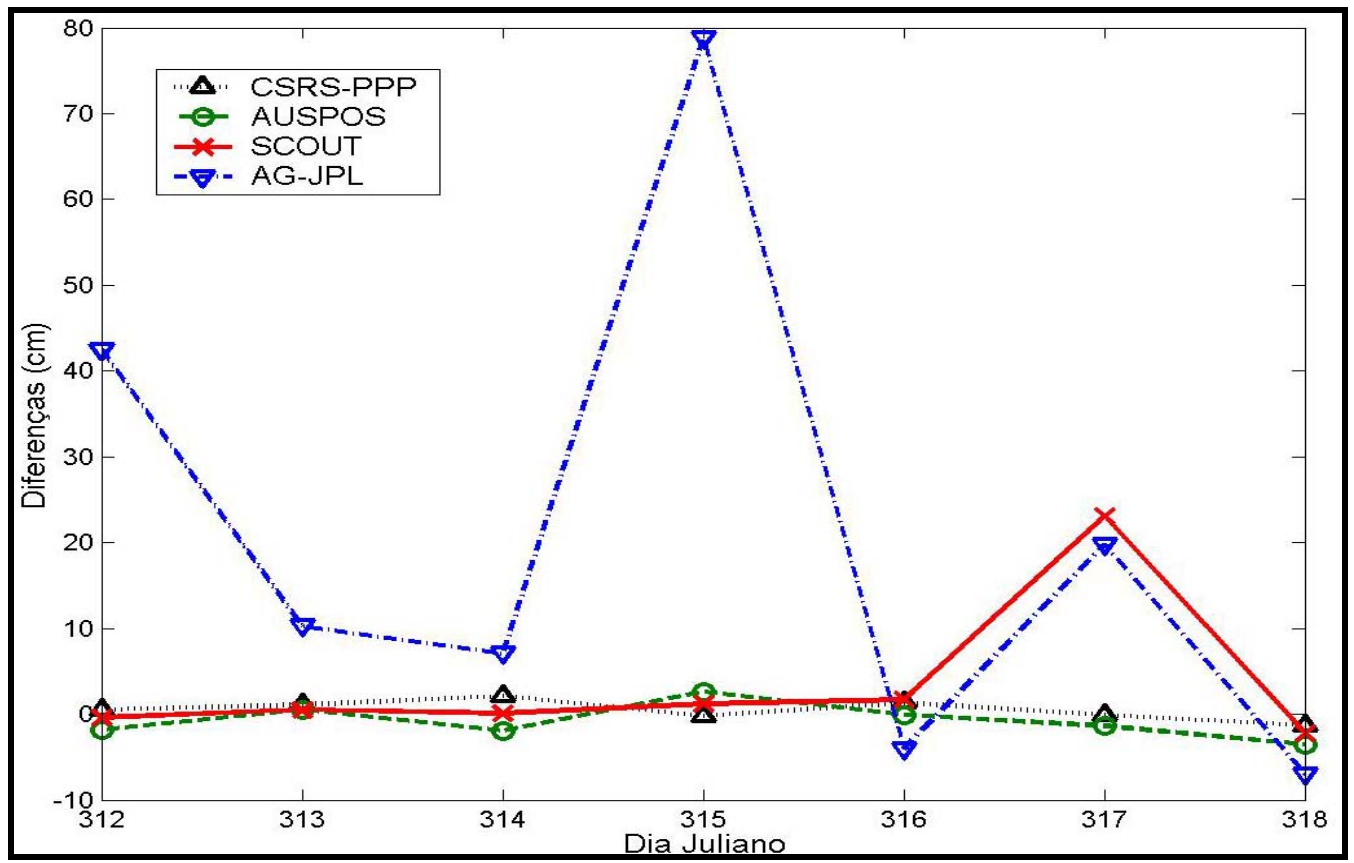

Figura 37: Gráfico das diferenças em altura na semana3.

\begin{tabular}{|c|c|c|c|}
\hline \multirow{2}{*}{ Serviço } & $\Delta$ Lat(cm) & $\Delta$ Long(cm) & $\Delta \mathbf{h}(\mathbf{c m})$ \\
\cline { 2 - 4 } & $\overline{\mathrm{x}} \pm \sigma$ & $\overline{\mathrm{x}} \pm \sigma$ & $\overline{\mathrm{x}} \pm \sigma$ \\
\hline CSRS-PPP & $-3,2 \pm 0,3$ & $0,9 \pm 0,4$ & $0,5 \pm 1,1$ \\
\hline AUSPOS & $-3,0 \pm 0,2$ & $0,9 \pm 0,4$ & $-0,8 \pm 2,0$ \\
\hline SCOUT & $-2,7 \pm 1,1$ & $2,9 \pm 8,4$ & $-3,4 \pm 8,8$ \\
\hline AG-JPL & $-6,4 \pm 6,4$ & $0,9 \pm 6,3$ & $21,1 \pm 30,3$ \\
\hline
\end{tabular}

Quadro 11 - Média e desvio padrão das diferenças da semana3

Examinando-se as Figuras 35, 36 e 37, e o Quadro da semana 3, observa-se que a ferramenta do JPL novamente retornou as coordenadas mais discrepantes, chegando a até $80 \mathrm{~cm}$ em relação às coordenadas da estação NEIA, e que o SCOUT apresentou uma diferença maior nas coordenadas do arquivo do dia 317 , chegando a uma diferença de até $20 \mathrm{~cm}$. 


\subsection{PROCESSAMENTO UTILIZANDO O SERVIÇO ON-LINE AUSPOS}

Neste segundo processamento foi utilizado apenas o serviço on-line AUSPOS, disponibilizado pelo Geoscience Australia. Os serviços AUSPOS e CSRS-PPP apresentaram os melhores resultados quando comparados aos outros dois (SCOUT/SOPAC e AG/JP), como pôde ser visto anteriormente. Para esta etapa de processamento foi escolhido o serviço AUSPOS ao invés do CSRS-PPP, pois o mesmo possibilita o envio de até 7 arquivos conjuntamente e fornece um relatório de pós-processamento mais completo.

\subsubsection{ENVIO E PROCESSAMENTO dos ARQUIVOS}

Os arquivos enviados para processamento estavam no mesmo padrão descrito na seção 4.1, diferindo apenas no período enviado para processamento, foram enviados dados de janeiro de 2003 e dezembro de 2004.

Como já foi dito anteriormente, o serviço AUSPOS utiliza estações do IGS para realizar o processamento, e no caso específico da estação NEIA as estações utilizadas foram: BRAZ (Brasília - Brasil), LPGS (La Plata - Argentina) e UNSA (Salta - Argentina), formando linhas de base de 1003 km, 1455 km e 1760 km, respectivamente.

Após o processamento dos dados, o relatório gerado pelo serviço é enviado para o e-mail designado pelo usuário. Neste caso, como na maioria das vezes eram enviados sete arquivos de uma única vez, o tempo de resposta geralmente era de aproximadamente duas a três horas.

Nesta análise será levada em consideração apenas a exatidão do processamento, ou seja, a diferença obtida entre a coordenada calculada e a coordenada fiducial da estação. 
Na seqüência são apresentadas as Figuras 38, 39 e 40, que mostram as diferenças diárias entre as coordenadas processadas e as coordenadas fiduciais da estação NEIA, encontradas para latitude, longitude e altura geométrica.

Foram tomadas como referência as mesmas coordenadas da estação NEIA utilizadas no processamento anterior (seção 4.2.4).

O Quadro 12 apresenta a tendência de deslocamento anual calculada para cada uma das coordenadas geodésicas (latitude, longitude e altura geométrica).

As linhas de tendência foram calculadas utilizando o método da regressão linear, e o seu desvio padrão foi calculado a partir da diferença entre os valores calculados e os valores gerados pela equação da reta para cada dia de processamento.

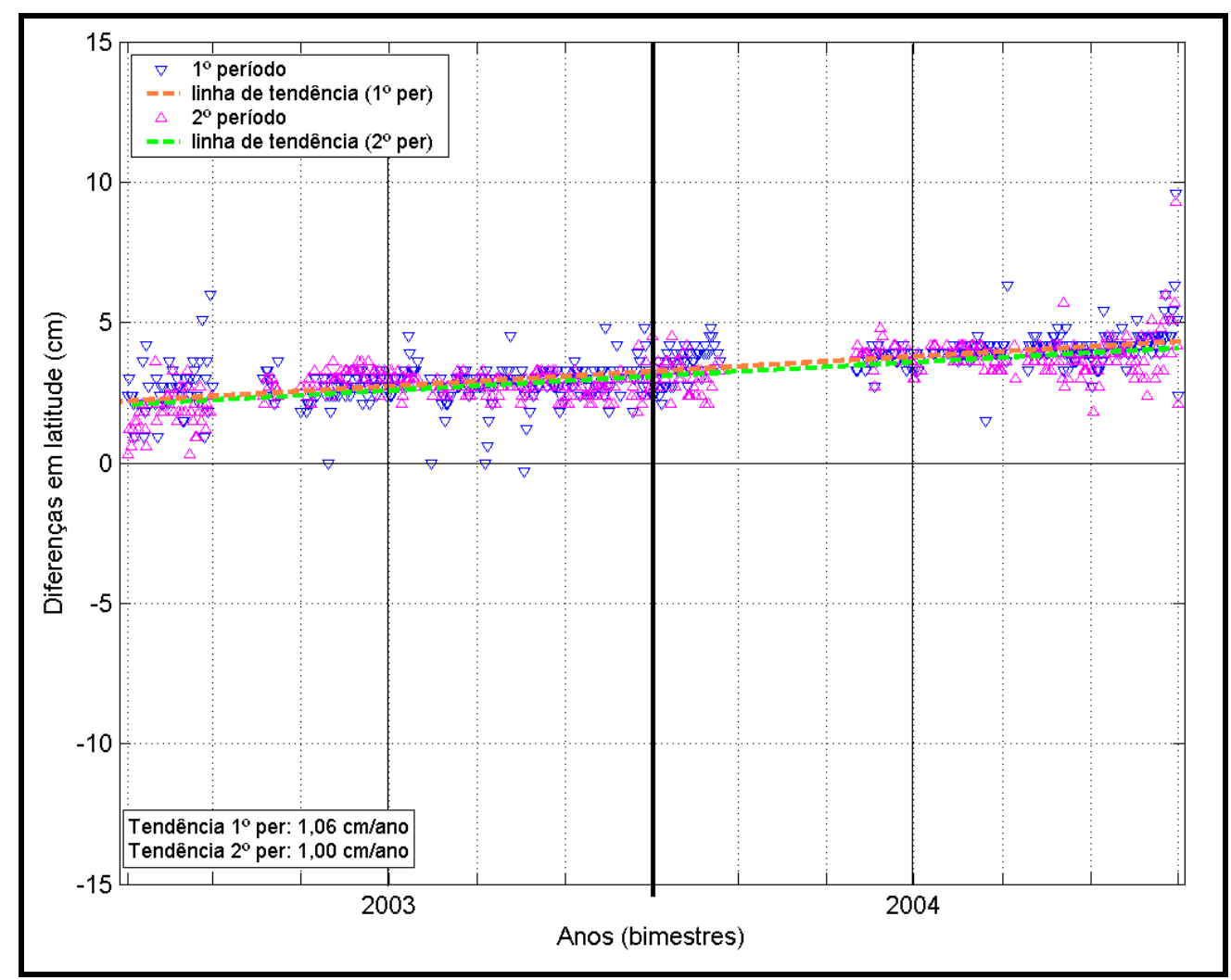

Figura 38: Gráfico das diferenças diárias em latitude para os dois períodos. 


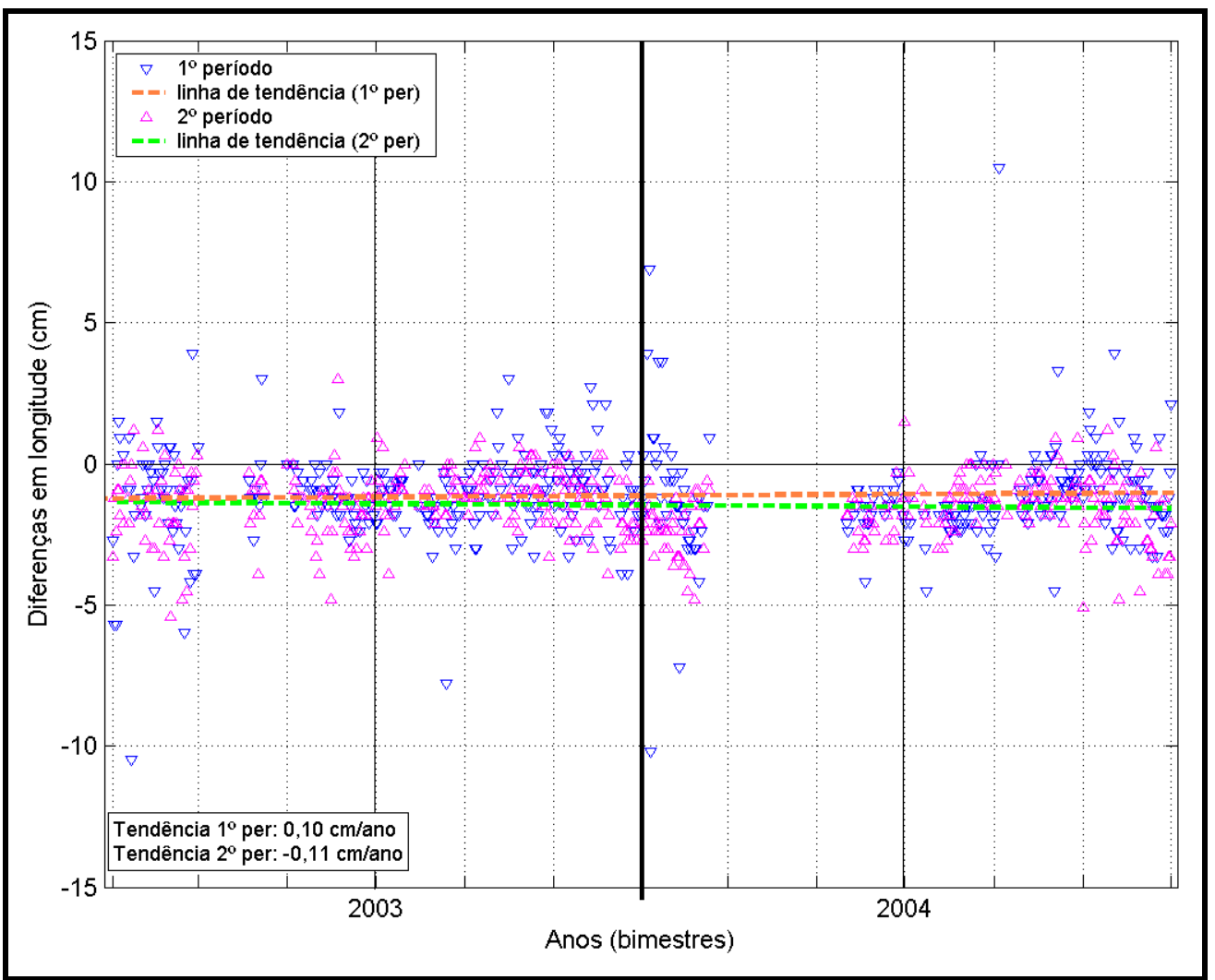

Figura 39: Gráfico das diferenças diárias em longitude para os dois períodos.

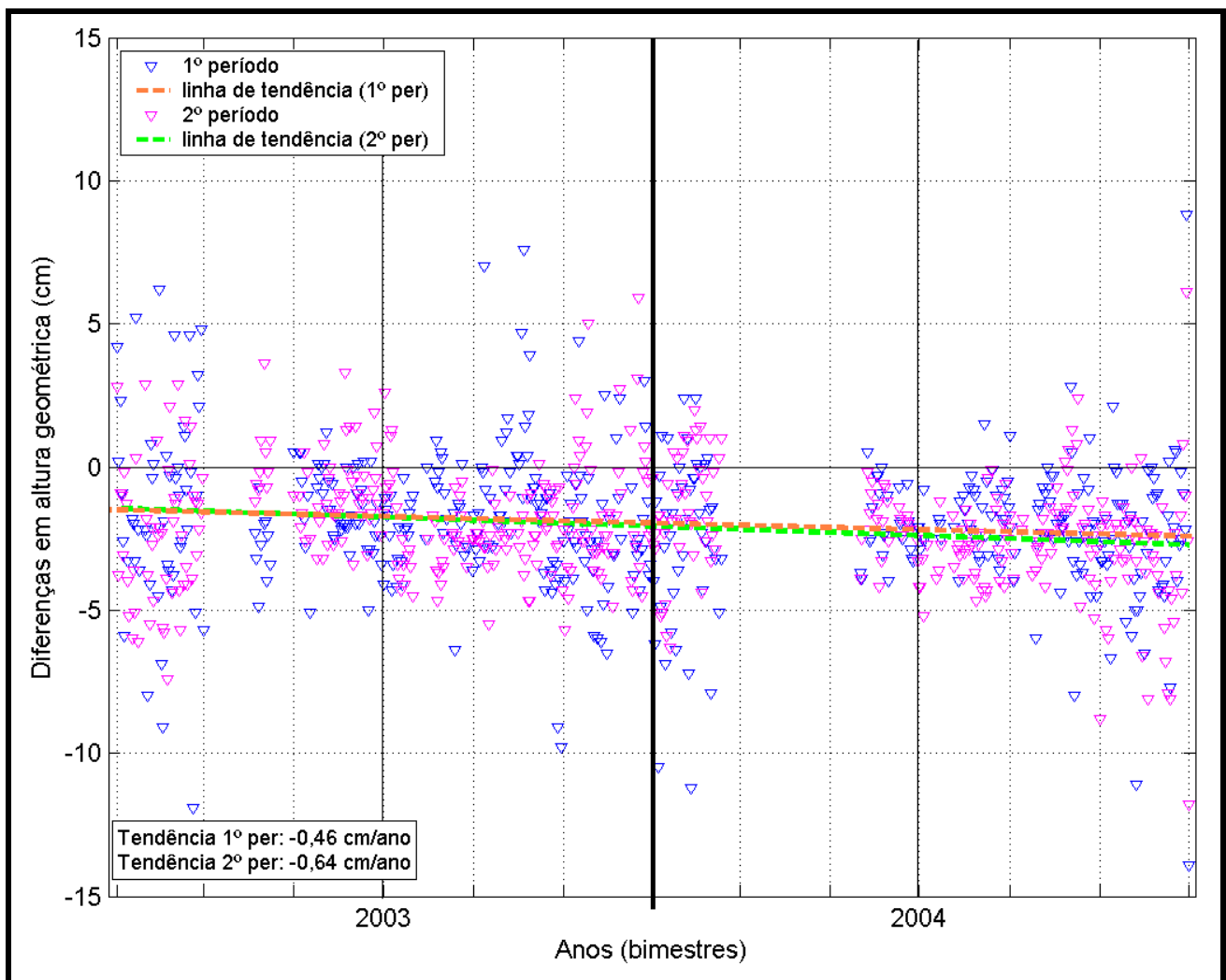

Figura 40: Gráfico das diferenças diárias em altura geométrica para os dois períodos. 


\begin{tabular}{|c|c|c|c|}
\hline \multirow{3}{*}{ Direção } & \multicolumn{2}{|c|}{ Tendência Anual (cm) } & \multirow{3}{*}{$\begin{array}{l}\text { Diferenças entre } \\
\text { os Períodos (cm) }\end{array}$} \\
\hline & $\begin{array}{l}\text { Oh UTC às } \\
12 \mathrm{~h} \text { UTC }\end{array}$ & $\begin{array}{l}\text { 12h UTC às } \\
23: 59 h \text { UTC }\end{array}$ & \\
\hline & $\bar{x} \pm \sigma$ & $\bar{x} \pm \sigma$ & \\
\hline Latitude & $1,06 \pm 0,71$ & $1,00 \pm 0,62$ & $-0,06$ \\
\hline Longitude & $0,10 \pm 1,65$ & $-0,11 \pm 1,12$ & $-0,20$ \\
\hline Alt. Geométrica & $-0,46 \pm 2,47$ & $-0,64 \pm 2,01$ & 0,18 \\
\hline
\end{tabular}

Quadro 12 - Tendências Anuais Calculadas

Analisando-se a linha de tendência nas Figuras 38, 39 e 40, e os valores do Quadro 12, pode-se notar que, a latitude apresentou comportamentos próximos para os dois períodos calculados, o mesmo ocorrendo para a altura geométrica. A longitude apresentou tendências inversas, houve um decréscimo no 1ำ período e um acréscimo no outro. Isso é devido ao fato da linha de tendência ter ficado praticamente paralela ao eixo das abscissas, e qualquer mudança em sua inclinação poderia inverter o sentido do deslocamento encontrado. Além disso, o seu desvio padrão calculado foi de aproximadamente $1,5 \mathrm{~cm}$, valor muito alto comparado a tendência calculada.

Através destas análises pode-se concluir que a estação NEIA vem sofrendo uma pequena variação em suas coordenadas, isso pode ser observado pelos resultados em latitude, que apresenta uma movimentação de aproximadamente 1,0 cm/ano na direção Norte e em altura geométrica, que vem diminuindo a uma razão de aproximadamente $0,5 \mathrm{~cm} /$ ano. Para longitude não se pode afirmar o sentido do deslocamento, pois para um período apresentou movimentação na direção Oeste (positiva) e para outro uma movimentação na direção Leste (negativa).

\subsection{PROCESSAMENTO UTILIZANDO O PROGRAMA BERNESE}

Para se poder afirmar o sentido dos deslocamentos encontrados pelo serviço AUSPOS em longitude, e confirmar os encontrados para latitude e altura geométrica, foi realizado o processamento com o uso do programa Bernese V. 5.0. 
O referido programa foi utilizado para a realização de dois processamentos distintos:

- No primeiro processamento não foi levada em consideração a propagação da velocidade das coordenadas da estação de referência PARA e;

- No segundo processamento um arquivo de velocidades foi utilizado na estação de referência PARA.

Em ambos foram utilizados os dados da estação NEIA que já haviam sido divididos em dois períodos (de $0 \mathrm{~h}$ às $12 \mathrm{hs}$ UTC, e outro de $12 \mathrm{hs}$ às $23 \mathrm{~h} 59 \mathrm{~min}$ UTC).

A seguir, são citados os modelos e parâmetros utilizados no processamento utilizando o programa Bernese:

- Modelo de Pólo: IERS2000;

- Modelo de Nutação: IAU2000;

- Modelo de maré oceânica: OT_CSRC;

- Modelo de troposfera: SAASTAMOINEN;

- Modelo de atraso zenital: WET NIELL;

- Estratégia de resolução da ambigüidade: SIGMA;

- Máscara de elevação: $10^{\circ}$ e;

- Intervalo entre as observações: 15 segundos.

Nesta etapa da pesquisa, foi utilizada a média móvel, sendo definida a ordem de 30 dias (1 mês). Devido ao grande número de dados que a série possuía, cerca de 1200 dias processados, a perda de dados no início e fim da série não gerou problemas.

\subsubsection{Primeiro Processamento}

Para a escolha da estação de referência foi realizado um teste de processamento utilizando as duas estações de referência mais próximas à estação NEIA, a saber, a estação PARA, situada em Curitiba/PR distante $140 \mathrm{~km}$, e a estação UEPP, situada em Presidente Prudente/SP distante $480 \mathrm{~km}$. Os períodos processados foram do dia 12 ao dia 41 do ano de 2002, e do dia 1 ao 31 de 2004. 
Nos Quadros 13 e 14 são apresentadas as médias e respectivos desvios padrão das diferenças entre as coordenadas calculadas e as fiduciais para latitude, longitude e altura geométrica, para cada linha de base processada.

\begin{tabular}{|c|c|c|c|}
\hline \multirow{2}{*}{ Linhas de Base (2002) } & $\Delta$ Lat (cm) & $\Delta$ Long (cm) & $\Delta \mathbf{h ~ ( c m ) ~}$ \\
\cline { 2 - 4 } & $\overline{\mathrm{x}} \pm \sigma$ & $\overline{\mathrm{x}} \pm \sigma$ & $\overline{\mathrm{x}} \pm \sigma$ \\
\hline PARA - NEIA & $0,06 \pm 0,21$ & $-0,27 \pm 0,32$ & $1,35 \pm 1,17$ \\
\hline UEPP - NEIA & $0,40 \pm 0,46$ & $-0,54 \pm 1,01$ & $1,50 \pm 1,04$ \\
\hline PARA - UEPP - NEIA & $0,32 \pm 0,47$ & $-0,57 \pm 0,41$ & $1,48 \pm 1,99$ \\
\hline
\end{tabular}

Quadro 13 - Média e desvio padrão das linhas de base (2002)

\begin{tabular}{|c|c|c|c|}
\hline \multirow{2}{*}{ Linhas de Base (2004) } & $\Delta$ Lat (cm) & $\Delta$ Long (cm) & $\Delta$ h (cm) \\
\cline { 2 - 4 } & $\overline{\mathrm{x}} \pm \sigma$ & $\overline{\mathrm{x}} \pm \sigma$ & $\overline{\mathrm{x}} \pm \sigma$ \\
\hline PARA - NEIA & $0,05 \pm 0,20$ & $-0,34 \pm 0,19$ & $0,41 \pm 0,67$ \\
\hline UEPP - NEIA & $0,16 \pm 0,41$ & $-0,67 \pm 0,63$ & $0,95 \pm 1,32$ \\
\hline PARA - UEPP - NEIA & $0,22 \pm 0,45$ & $-0,61 \pm 0,32$ & $0,95 \pm 0,89$ \\
\hline
\end{tabular}

Quadro 14 - Média e desvio padrão das linhas de base (2004)

Nos Quadros 13 e 14, pode-se observar que os valores de média e desvio calculados para a linha de base NEIA-PARA são sempre menores do que os valores calculados quando se inclui a estação UEPP e apesar das diferenças entre os processamentos ser milimétrica, relativamente ela chega a ser até sete vezes maior. Isso se deve ao fato da estação UEPP estar afastada da estação NEIA a uma distância três vezes maior que da estação PARA, gerando uma incerteza maior na determinação da linha de base. Por este motivo, foi utilizada apenas a estação PARA como referência nos dois processamentos.

No processamento, utilizando o programa Bernese V5.0, foi utilizado o método relativo, onde foram fixadas as coordenadas da estação PARA para determinar as coordenadas da estação NEIA. Foram tomadas como referência as coordenadas da estação PARA, calculadas pelo IBGE e referidas ao SIRGAS2000 (época 2000.4), disponibilizadas no sítio do próprio Instituto. Essas coordenadas são (INSTITUTO BRASILEIRO DE GEOGRAFIA E ESTATÍSTICA, 2006): 


$$
\begin{aligned}
& -\varphi=25^{\circ} 26^{\prime} 54,1269^{\prime \prime} \mathrm{S} \\
& -\lambda=49^{\circ} 13^{\prime} 51,4373^{\prime \prime} \mathrm{W} \\
& -\mathrm{h}=925,770 \mathrm{~m}
\end{aligned}
$$

\subsubsection{RESULTADOS}

Posteriormente ao processamento foi gerado um arquivo de saída para cada arquivo processado. Através de um script em UNIX foram extraídas as coordenadas finais de cada dia processado. Depois de coletadas as informações de interesse, no caso, os valores de latitude, longitude e altura geométrica calculados, os dados foram tabulados e comparados às coordenadas fiduciais da estação NEIA, sendo que, serão apresentados os resultados para latitude, longitude e altura geométrica, respectivamente.

\subsection{LATITUDE}

Para a latitude, os resultados das diferenças dos dois períodos analisados são apresentados no Quadro 15, que traz as diferenças divididas em classes e sua freqüência de ocorrência. 


\begin{tabular}{|c|c|c|}
\hline \multirow{2}{*}{ Diferenças (cm) } & \multicolumn{2}{|c|}{ № de arquivos (\% da amostra) } \\
\hline & 1ํo período & $2^{\circ}$ período \\
\hline$<1$ & $1047(96,7 \%)$ & $1037(96,6 \%)$ \\
\hline $1 \vdash 2$ & $4(0,4 \%)$ & $6(0,6 \%)$ \\
\hline $2 \vdash 3$ & $3(0,3 \%)$ & $1(0,1 \%)$ \\
\hline $3 \vdash 4$ & $1(0,1 \%)$ & $0(0,0 \%)$ \\
\hline $4 \vdash 5$ & $3(0,3 \%)$ & $0(0,0 \%)$ \\
\hline $5 \vdash 10$ & $3(0,3 \%)$ & $2(0,2 \%)$ \\
\hline $10 \vdash 50$ & $14(1,3 \%)$ & $12(1,1 \%)$ \\
\hline $50-100$ & $4(0,4 \%)$ & $5(0,5 \%)$ \\
\hline$>100$ & $4(0,4 \%)$ & $11(1,0 \%)$ \\
\hline
\end{tabular}

Quadro 15 - Valores das diferenças diárias em latitude

Antes da construção do gráfico das diferenças em latitude, os dados passaram por uma filtragem (item 3.5.1). O Quadro 16 apresenta os valores calculados para detecção e eliminação de outliers e a Figura 41 traz o boxplot onde estão representados os valores utilizados como corte para filtragem das diferenças.

\begin{tabular}{|c|c|c|}
\hline \multirow{2}{*}{ Indicadores } & \multicolumn{2}{|c|}{ Latitude $(\mathrm{cm})$} \\
\hline & $1^{\circ}$ período & $2^{\circ}$ período \\
\hline Mínimo & $-557,80$ & $-358,41$ \\
\hline Máximo & 192,95 & 541,97 \\
\hline 1ㅇQ Quartil & $-0,04$ & $-0,05$ \\
\hline Mediana & 0,10 & 0,12 \\
\hline 3ํo Quartil & 0,23 & 0,26 \\
\hline Limite Inferior & $-0,46$ & $-0,51$ \\
\hline Limite Superior & 0,65 & 0,73 \\
\hline
\end{tabular}

Quadro 16 - Valores calculados para eliminação de outliers em latitude 


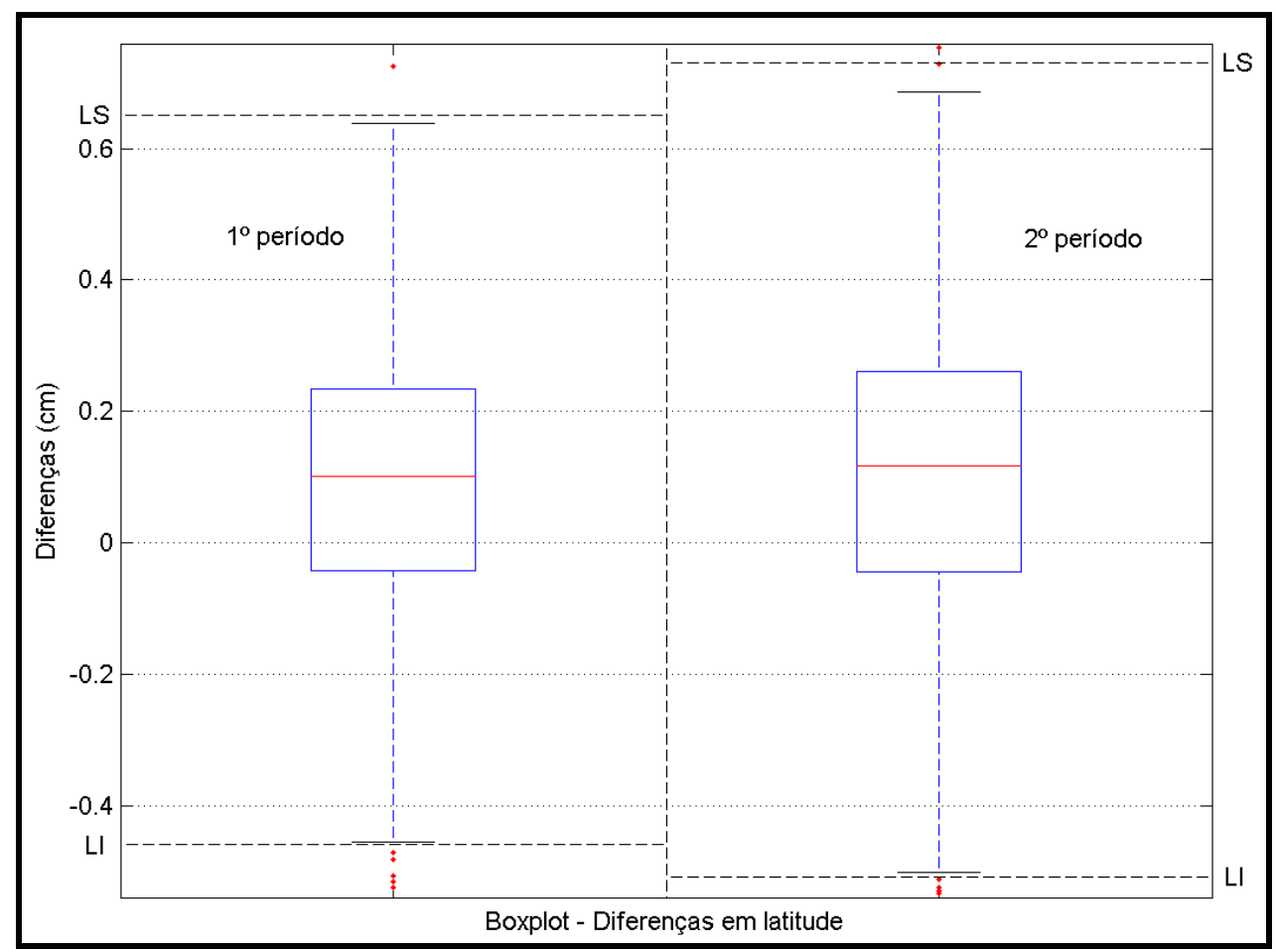

Figura 41: Boxplot das diferenças diárias em latitude para os dois períodos.

A Figura 42 apresenta as diferenças encontradas para latitude. Os resultados dos dois períodos estão apresentados no mesmo gráfico para facilitar a visualização, além de ser apresentada ainda, a média móvel para cada período.

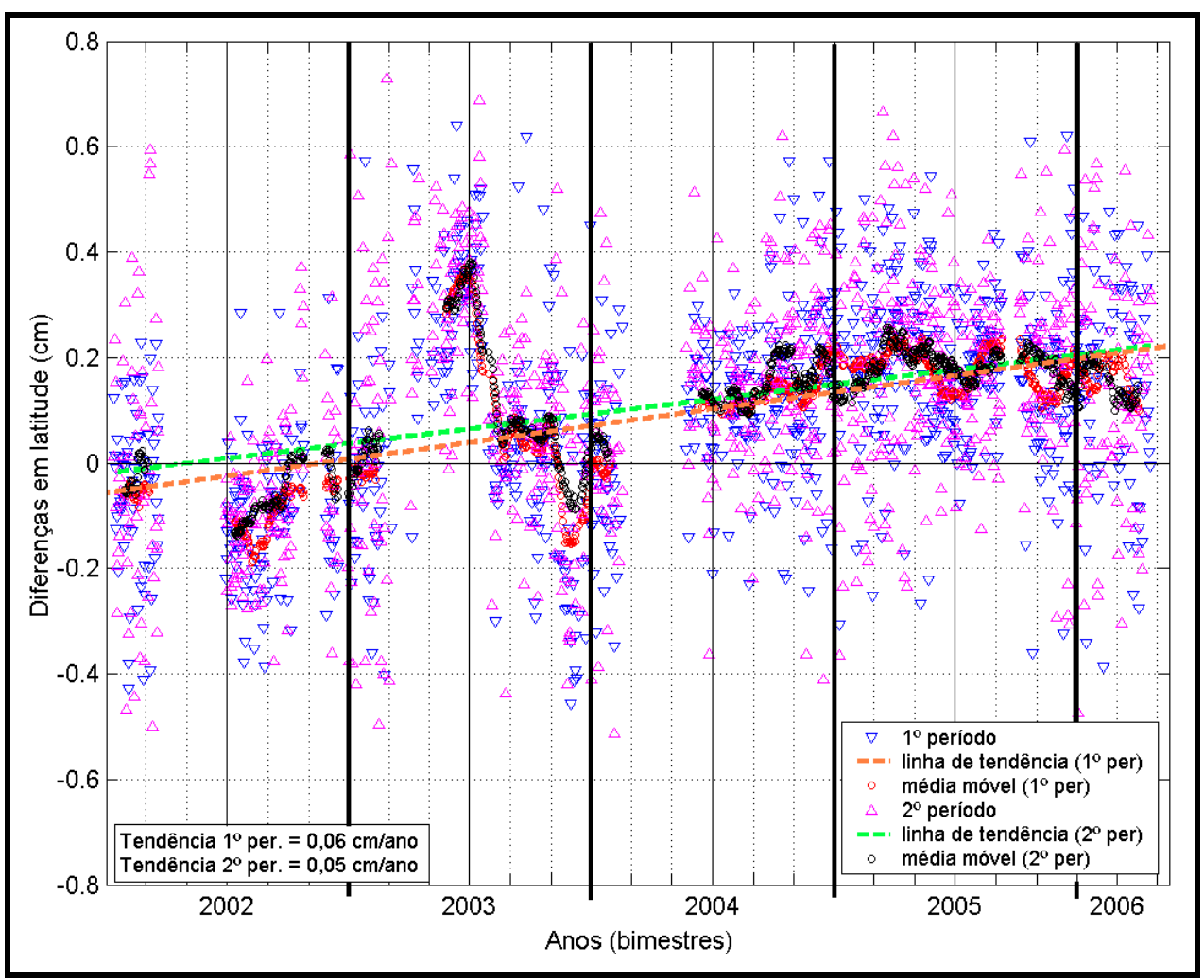

Figura 42: Gráfico das diferenças diárias em latitude após filtragem 


\subsection{LONGITUDE}

O Quadro 17 apresenta os resultados das diferenças e sua freqüência de ocorrência, para os dois períodos analisados em longitude.

\begin{tabular}{|c|c|c|}
\hline \multirow{2}{*}{ Diferenças (cm) } & \multicolumn{2}{|c|}{ № de arquivos (\% da amostra) } \\
\cline { 2 - 3 } & 1o período & 2 período \\
\hline$<1$ & $1015(93,7 \%)$ & $982(91,4 \%)$ \\
\hline $1 \vdash 2$ & $25(2,3 \%)$ & $55(5,1 \%)$ \\
\hline $2 \vdash 3$ & $4(0,4 \%)$ & $1(0,1 \%)$ \\
\hline $3 \vdash 4$ & $1(0,1 \%)$ & $1(0,1 \%)$ \\
\hline $4 \vdash 5$ & $1(0,1 \%)$ & $0(0,0 \%)$ \\
\hline $5 \vdash 10$ & $5(0,5 \%)$ & $3(0,3 \%)$ \\
\hline $10 \vdash 50$ & $8(0,7 \%)$ & $8(0,7 \%)$ \\
\hline $50 \vdash 100$ & $7(0,6 \%)$ & $6(0,6 \%)$ \\
\hline$>100$ & $17(1,6 \%)$ & $18(1,7 \%)$ \\
\hline
\end{tabular}

Quadro 17 - Valores das diferenças diárias em longitude

Os valores utilizados para a filtragem das diferenças calculadas para longitude estão no Quadro 18, sendo que, a Figura 43 apresenta o boxplot com os valores utilizados para a eliminação de outliers. 


\begin{tabular}{|c|c|c|}
\hline \multirow{2}{*}{ Indicadores } & \multicolumn{2}{|c|}{ Longitude (cm) } \\
\cline { 2 - 3 } & $\mathbf{1}^{\text {o }}$ período & $\mathbf{2}^{\text {o }}$ período \\
\hline Mínimo & $-627,80$ & $-460,01$ \\
\hline Máximo & 1699,98 & 454,43 \\
\hline 1음 Quartil $^{*}$ Mediana & 0,32 & 0,32 \\
\hline $3^{\text {o }}$ Quartil & 0,50 & 0,52 \\
\hline Limite Inferior & 0,69 & 0,73 \\
\hline Limite Superior & $-0,23$ & $-0,28$ \\
\hline
\end{tabular}

Quadro 18 - Valores calculados para eliminação de outliers em longitude

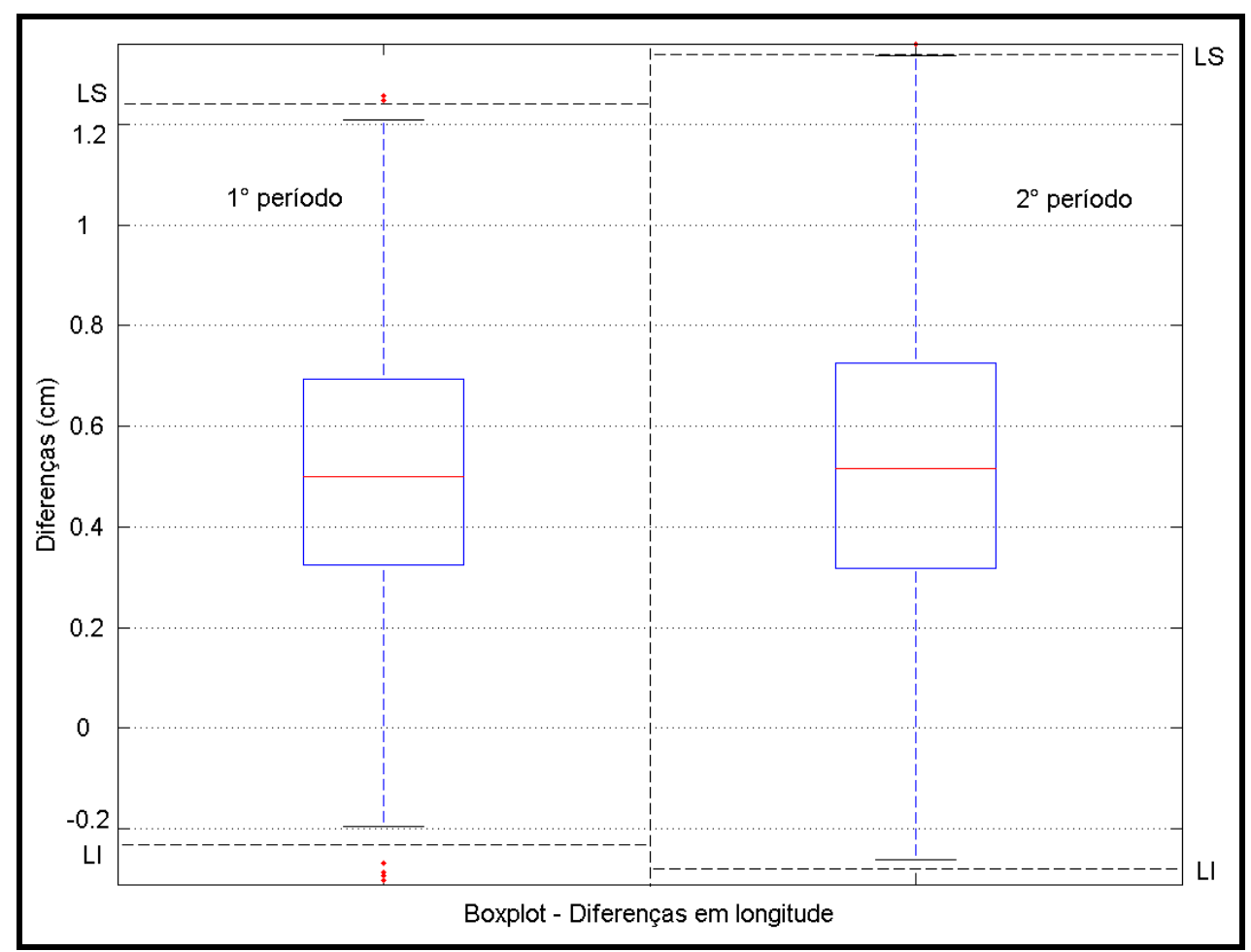

Figura 43: Boxplot das diferenças diárias em longitude para os dois períodos.

As diferenças calculadas para longitude nos dois períodos, com os outliers já eliminados, são apresentadas na Figura 44, junto com a média móvel para cada período. 


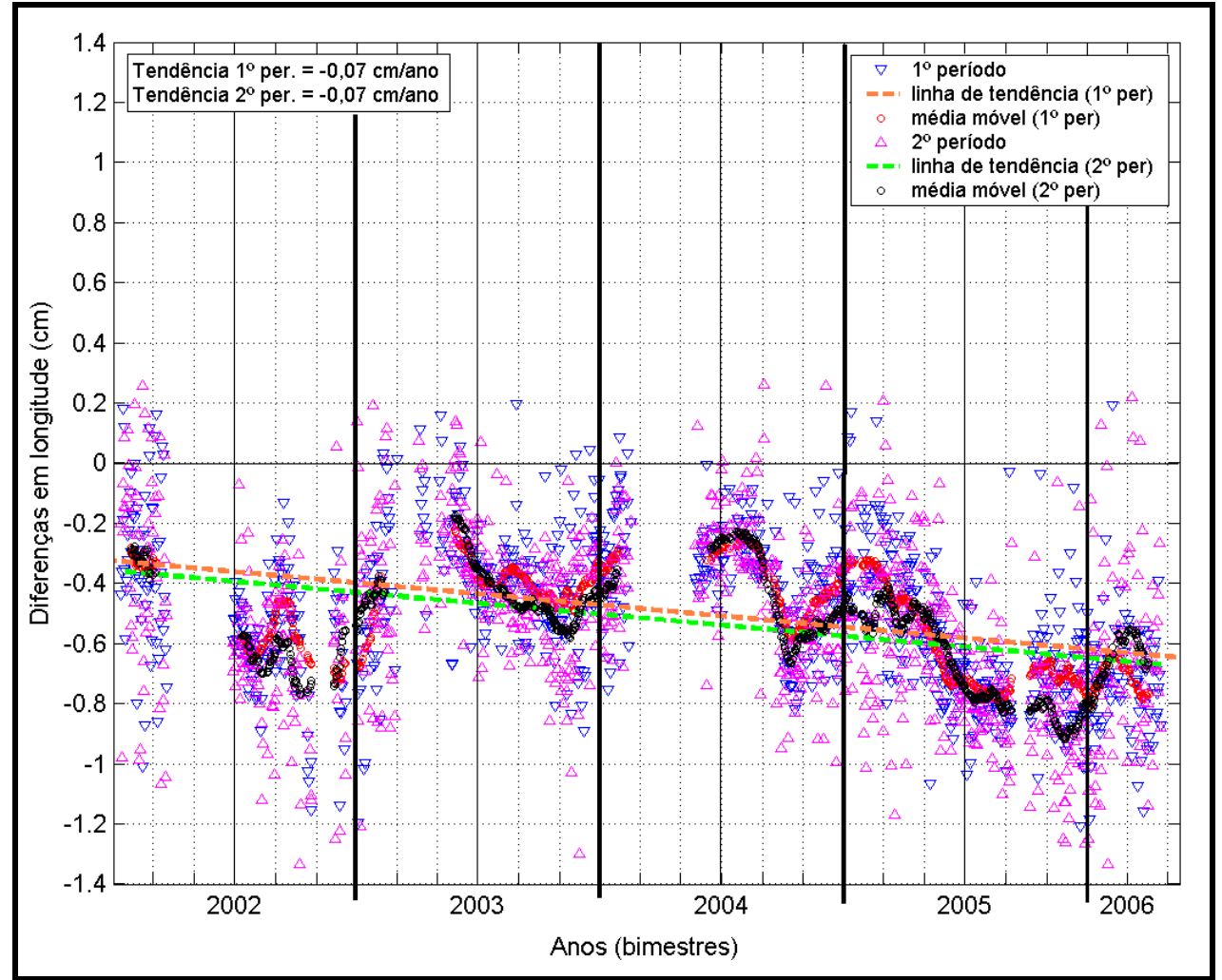

Figura 44: Gráfico das diferenças diárias em longitude após filtragem

\subsection{Altura GeomÉtrica}

A primeira análise realizada para as diferenças em altura geométrica, é mostrada no Quadro 19, que traz as diferenças apresentadas em classes e sua freqüência de ocorrência. 


\begin{tabular}{|c|c|c|}
\hline \multirow{2}{*}{ Diferenças (cm) } & \multicolumn{2}{|c|}{ № de arquivos (\% da amostra) } \\
\cline { 2 - 3 } & 1음 período & 20 período \\
\hline$<1$ & $570(52,6 \%)$ & $608(56,6 \%)$ \\
\hline $1 \vdash 2$ & $389(35,9 \%)$ & $318(29,6 \%)$ \\
\hline $2 \vdash 3$ & $57(5,3 \%)$ & $61(5,7 \%)$ \\
\hline $3 \vdash 4$ & $10(0,9 \%)$ & $21(2,0 \%)$ \\
\hline $4 \vdash 5$ & $2(0,2 \%)$ & $5(0,5 \%)$ \\
\hline $5 \vdash 10$ & $3(0,3 \%)$ & $9(0,8 \%)$ \\
\hline $10 \vdash 50$ & $27(2,5 \%)$ & $25(2,3 \%)$ \\
\hline $50 \vdash 100$ & $5(0,5 \%)$ & $2(0,2 \%)$ \\
\hline$>100$ & $20(1,8 \%)$ & $25(2,3 \%)$ \\
\hline
\end{tabular}

Quadro 19 - Valores das diferenças diárias em altura geométrica

Os dados, antes da construção do gráfico das diferenças em altura geométrica, passaram por uma filtragem para eliminação de possíveis outliers, sendo que, estes valores são apresentados no Quadro 20. A Figura 45 traz o boxplot que representa os valores apresentados no Quadro 20.

\begin{tabular}{|c|c|c|}
\hline \multirow{2}{*}{ Indicativo } & \multicolumn{2}{|c|}{ Alt. Geométrica (cm) } \\
\hline & 1ㅇp. & $2^{\circ}$ per. \\
\hline Mínimo & $-1068,68$ & $-589,00$ \\
\hline Máximo & 3694,64 & 1147,43 \\
\hline 1ㅇ Quartil & 0,22 & 0,33 \\
\hline Mediana & 0,83 & 0,8 \\
\hline 3ํQuartil & 1,4 & 1,38 \\
\hline Limite Inferior & $-1,55$ & $-1,24$ \\
\hline Limite Superior & 3,17 & 2,95 \\
\hline
\end{tabular}

Quadro 20 - Valores calculados para eliminação de outliers em altura geométrica 


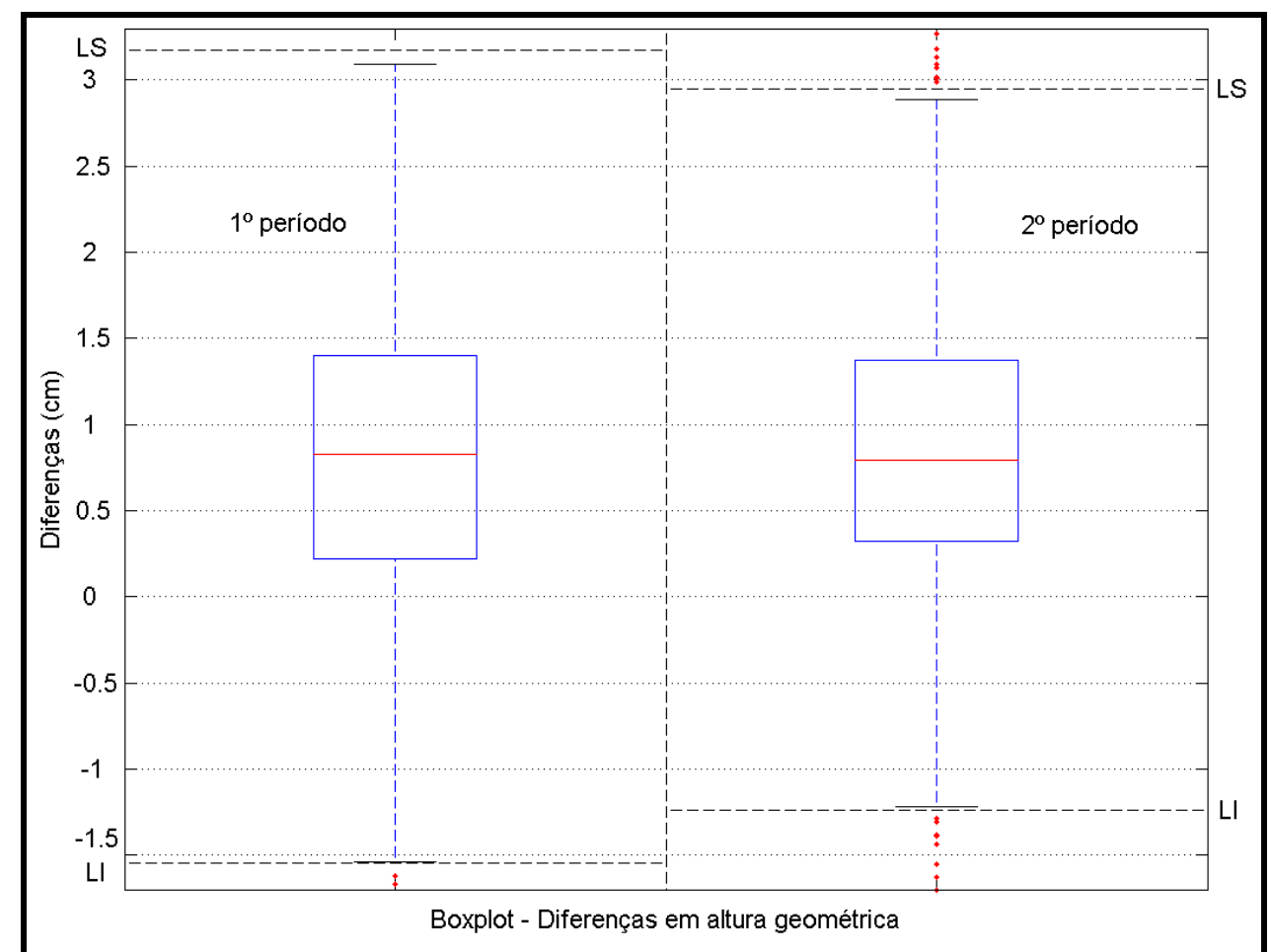

Figura 45: Boxplot das diferenças diárias em altura geométrica para os dois períodos.

A Figura 46 traz as diferenças calculadas para altitude geométrica, sendo que, os resultados dos dois períodos, além de sua média móvel, estão apresentados no mesmo gráfico para facilitar a comparação entre ambos.

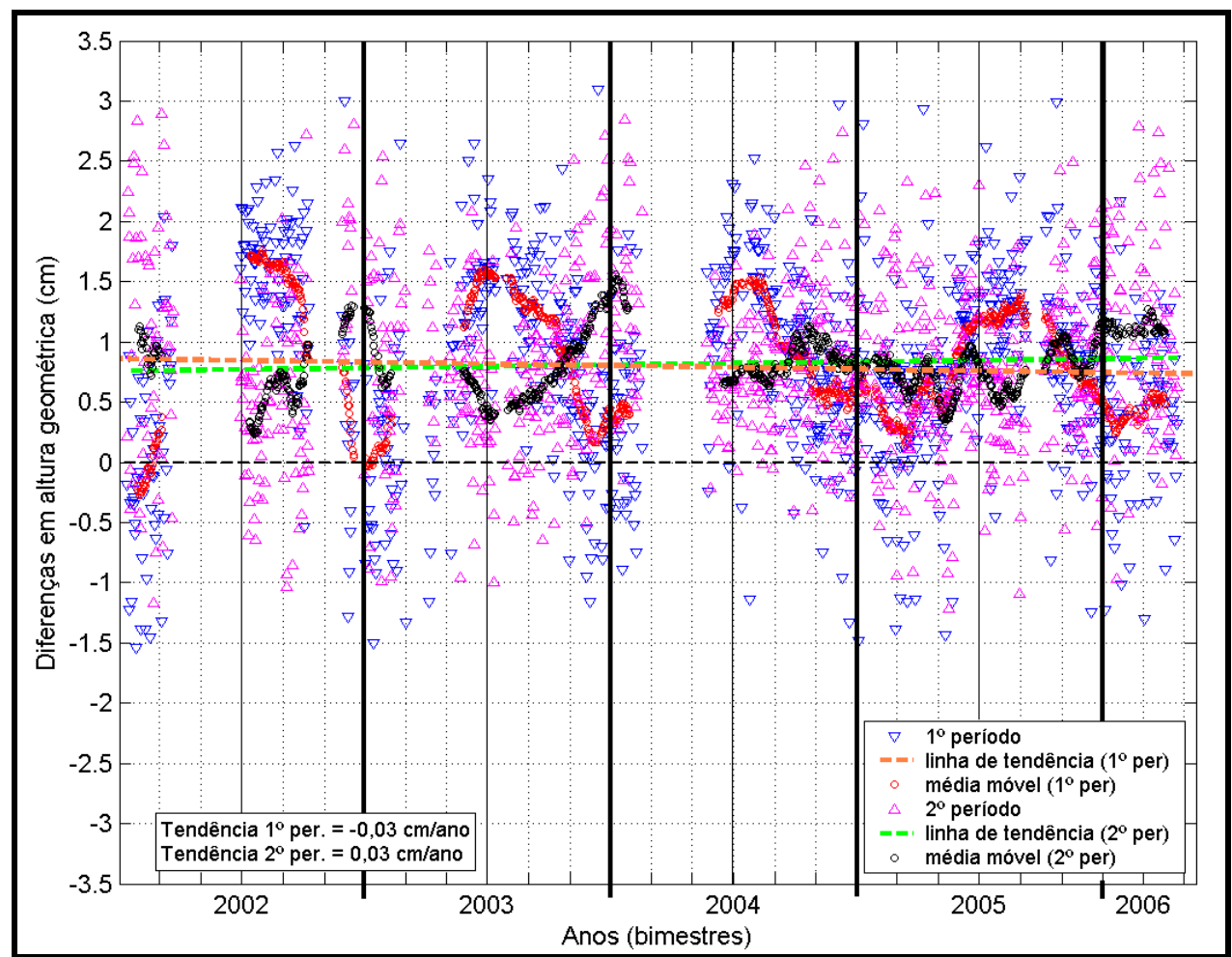

Figura 46: Gráfico das diferenças diárias em altura geométrica após filtragem 
O Quadro 21 apresenta os valores de mínimo, máximo, média e desvio padrão extraídos a partir dos dados utilizados para a construção das Figuras 42, 44 e 46. No Quadro 22 são apresentados os deslocamentos anuais calculados e seu respectivo desvio padrão para cada uma das três componentes.

\begin{tabular}{|c|c|c|c|c|c|c|}
\hline \multirow{2}{*}{ Indicativo } & \multicolumn{2}{|c|}{ Latitude (cm) } & \multicolumn{2}{|c|}{ Longitude (cm) } & \multicolumn{2}{|c|}{ Alt. Geométrica (cm) } \\
\hline & $1^{\circ}$ per. & $2^{\circ}$ per. & $1^{\circ}$ per. & $2^{\circ}$ per. & $1^{\circ}$ per. & $2^{\circ}$ per. \\
\hline Mínimo & $-0,46$ & $-0,51$ & $-0,20$ & $-0,26$ & $-1,54$ & $-1,22$ \\
\hline Máximo & 0,64 & 0,73 & 1,21 & 1,33 & 3,09 & 2,89 \\
\hline Média (x) & 0,09 & 0,11 & 0,50 & 0,53 & 0,79 & 0,81 \\
\hline Desvio $(\sigma)$ & 0,20 & 0,21 & 0,24 & 0,28 & 0,81 & 0,72 \\
\hline
\end{tabular}

Quadro 21 - Diferenças em latitude, longitude e altura geométrica após a filtragem

\begin{tabular}{|c|c|c|c|}
\hline \multirow{3}{*}{ Direção } & \multicolumn{2}{|c|}{ Tendência anual (cm) } & \multirow{3}{*}{$\begin{array}{l}\text { Diferenças entre } \\
\text { os períodos }(\mathrm{cm})\end{array}$} \\
\hline & 1ํo período & 2ํo período & \\
\hline & $\bar{x} \pm \sigma$ & $\bar{x} \pm \sigma$ & \\
\hline Latitude & $0,06 \pm 0,18$ & $0,05 \pm 0,20$ & 0,01 \\
\hline Longitude & $-0,07 \pm 0,23$ & $-0,07 \pm 0,27$ & 0,00 \\
\hline Altura Geométrica & $-0,03 \pm 0,81$ & $0,03 \pm 0,72$ & $-0,06$ \\
\hline
\end{tabular}

Quadro 22 - Deslocamentos anuais calculados

Analisando-se as Figuras 42, 44 e 46 e os quadros 21 e 22 pode-se observar que não houve uma tendência significativa, o que demonstra que a estação não sofre nenhum tipo de movimento relativo em relação à estação de referência.

As médias móveis apresentadas para latitude e longitude, nos dois períodos, são praticamente coincidentes. Já a média móvel calculada para a altura apresentase discrepante entre os dois períodos, podendo ser ocasionada devido a influência da carga oceânica e/ou maré terrestre ser diferente para os dois períodos. 


\subsubsection{Segundo Processamento}

O segundo processamento utilizando o programa Bernese V. 5.0 foi realizado também no modo relativo, fixando-se as coordenadas da estação PARA visando a determinação das coordenadas da estação NEIA, sendo adotadas como referência as mesmas coordenadas utilizadas na seção 4.4.1.

A seqüência de processamento foi idêntica a anterior, com exceção de um módulo que foi adicionado, o COOVEL (descrito no item 3.3.2), sendo que, os parâmetros de propagação de velocidades utilizados foram fornecidos pelo IBGE.

\subsubsection{RESULTADOS}

Após o processamento dos dados GPS, as coordenadas de cada arquivo foram extraídas aproveitando o mesmo script em UNIX utilizado anteriormente. Depois de extraídas as informações, os dados foram tabulados e comparados às coordenadas fiduciais da estação NEIA (seção 4.4.1), sendo que, os resultados para latitude, longitude e altura geométrica são apresentados a seguir.

\subsection{LATITUDE}

Depois de calculadas as diferenças para latitude utilizando o módulo COOVEL, as mesmas foram tabuladas e são apresentadas no Quadro 23. 


\begin{tabular}{|c|c|c|}
\hline \multirow{2}{*}{ Diferenças (cm) } & \multicolumn{2}{|c|}{ № de arquivos (\% da amostra) } \\
\hline & $1^{\circ}$ período & $2^{\circ}$ período \\
\hline$<1$ & $1(0,1 \%)$ & $0(0,0 \%)$ \\
\hline $1 \vdash 2$ & $9(0,8 \%)$ & $16(1,5 \%)$ \\
\hline $2 \vdash 3$ & $152(14,1 \%)$ & $145(13,5 \%)$ \\
\hline $3 \vdash 4$ & $114(10,6 \%)$ & $109(10,1 \%)$ \\
\hline $4 \vdash 5$ & $210(19,5 \%)$ & $219(20,4 \%)$ \\
\hline $5 \vdash 10$ & $571(52,9 \%)$ & $561(52,1 \%)$ \\
\hline $10 \vdash 50$ & $15(1,4 \%)$ & $9(0,8 \%)$ \\
\hline $50 \vdash 100$ & $4(0,4 \%)$ & $5(0,5 \%)$ \\
\hline$>100$ & $3(0,3 \%)$ & $12(1,1 \%)$ \\
\hline
\end{tabular}

Quadro 23 - Valores das diferenças diárias em latitude utilizando o módulo COOVEL

Para a construção do gráfico das diferenças em latitude, foi necessário que os dados passassem por uma filtragem a fim de eliminar os outliers. Os valores utilizados para a filtragem estão no quadro 24 .

\begin{tabular}{|c|c|c|}
\hline \multirow{2}{*}{ Indicativo } & \multicolumn{2}{|c|}{ Latitude (cm) } \\
\hline & $1^{\circ}$ período & $2^{\circ}$ período \\
\hline Mínimo & $-475,81$ & $-358,41$ \\
\hline Máximo & 196,50 & 545,48 \\
\hline 1ㅇ Quartil & 3,95 & 3,87 \\
\hline Mediana & 5,31 & 5,23 \\
\hline 3으 Quartil & 6,38 & 6,36 \\
\hline Limite Inferior & 0,30 & 0,13 \\
\hline Limite Superior & 10,03 & 10,10 \\
\hline
\end{tabular}

Quadro 24 - Valores calculados para eliminação de outliers em latitude

A partir dos valores tabulados no Quadro 24, foi possível montar os boxplots (Figura 47), que representa graficamente os limites utilizados na filtragem. 


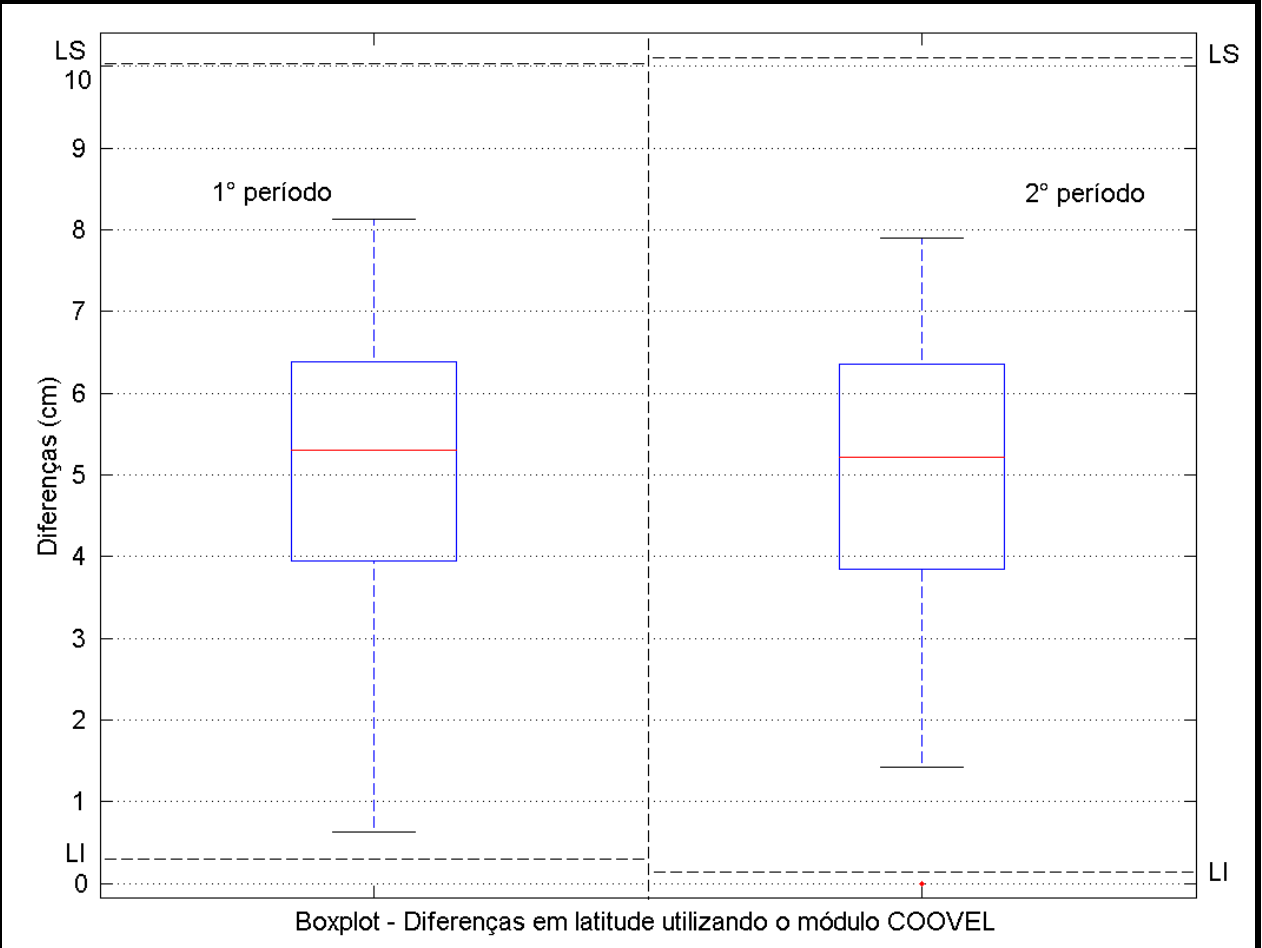

Figura 47: Boxplot das diferenças diárias em latitude para os dois períodos.

Após a filtragem dos dados, os mesmos foram utilizados para construir o gráfico (Figura 48), onde são representadas as diferenças em latitude e a média móvel para os dois períodos, além das linhas de tendência.

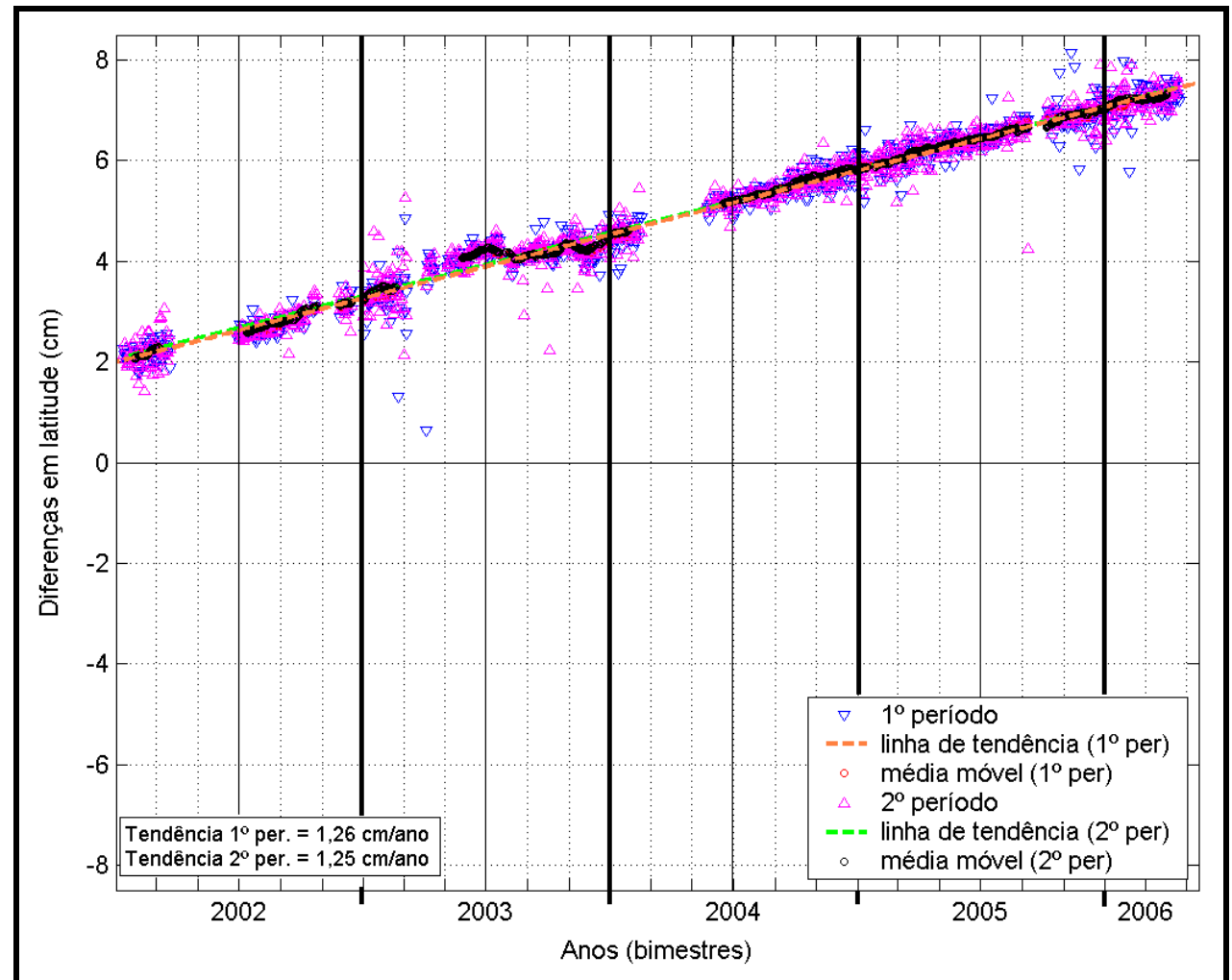

Figura 48: Gráfico das diferenças diárias em latitude utilizando o módulo COOVEL, após filtragem. 


\subsection{LONGITUDE}

O quadro 25 apresenta os valores das diferenças calculadas para os dois períodos, em longitude, divididas em classes de freqüência de ocorrência.

\begin{tabular}{|c|c|c|}
\hline \multirow{2}{*}{ Diferenças (cm) } & \multicolumn{2}{|c|}{ № de arquivos (\% da amostra) } \\
\cline { 2 - 3 } & 1o período & 2- período \\
\hline$<1$ & $409(37,9 \%)$ & $447(41,5 \%)$ \\
\hline $1 \vdash 2$ & $631(58,5 \%)$ & $581(54,0 \%)$ \\
\hline $2 \vdash 3$ & $5(0,5 \%)$ & $13(1,2 \%)$ \\
\hline $3 \vdash 4$ & $1(0,1 \%)$ & $0(0,0 \%)$ \\
\hline $4 \vdash 5$ & $0(0,0 \%)$ & $1(0,1 \%)$ \\
\hline $5 \vdash 10$ & $5(0,5 \%)$ & $3(0,3 \%)$ \\
\hline $10 \vdash 50$ & $10(0,9 \%)$ & $8(0,7 \%)$ \\
\hline $50 \vdash 100$ & $4(0,4 \%)$ & $5(0,5 \%)$ \\
\hline$>100$ & $14(1,3 \%)$ & $18(1,7 \%)$ \\
\hline
\end{tabular}

Quadro 25 - Valores das diferenças diárias em longitude

Os valores utilizados na filtragem das diferenças em longitude, para ambos os períodos, constam no quadro 26 , e o respectivo boxplot está representado na Figura 49. 


\begin{tabular}{|c|c|c|}
\hline \multirow{2}{*}{ Indicativo } & \multicolumn{2}{|c|}{ Longitude (cm) } \\
\cline { 2 - 3 } & 1o período & 2o período \\
\hline Mínimo & $-628,91$ & $-460,99$ \\
\hline Máximo & 430,21 & 453,43 \\
\hline 1o Quartil & $-1,35$ & $-1,32$ \\
\hline Mediana & $-1,15$ & $-1,09$ \\
\hline 3o Quartil & $-0,76$ & $-0,75$ \\
\hline Limite Inferior & $-2,23$ & $-2,17$ \\
\hline Limite Superior & 0,11 & 0,09 \\
\hline
\end{tabular}

Quadro 26 - Valores calculados para eliminação de outliers em longitude

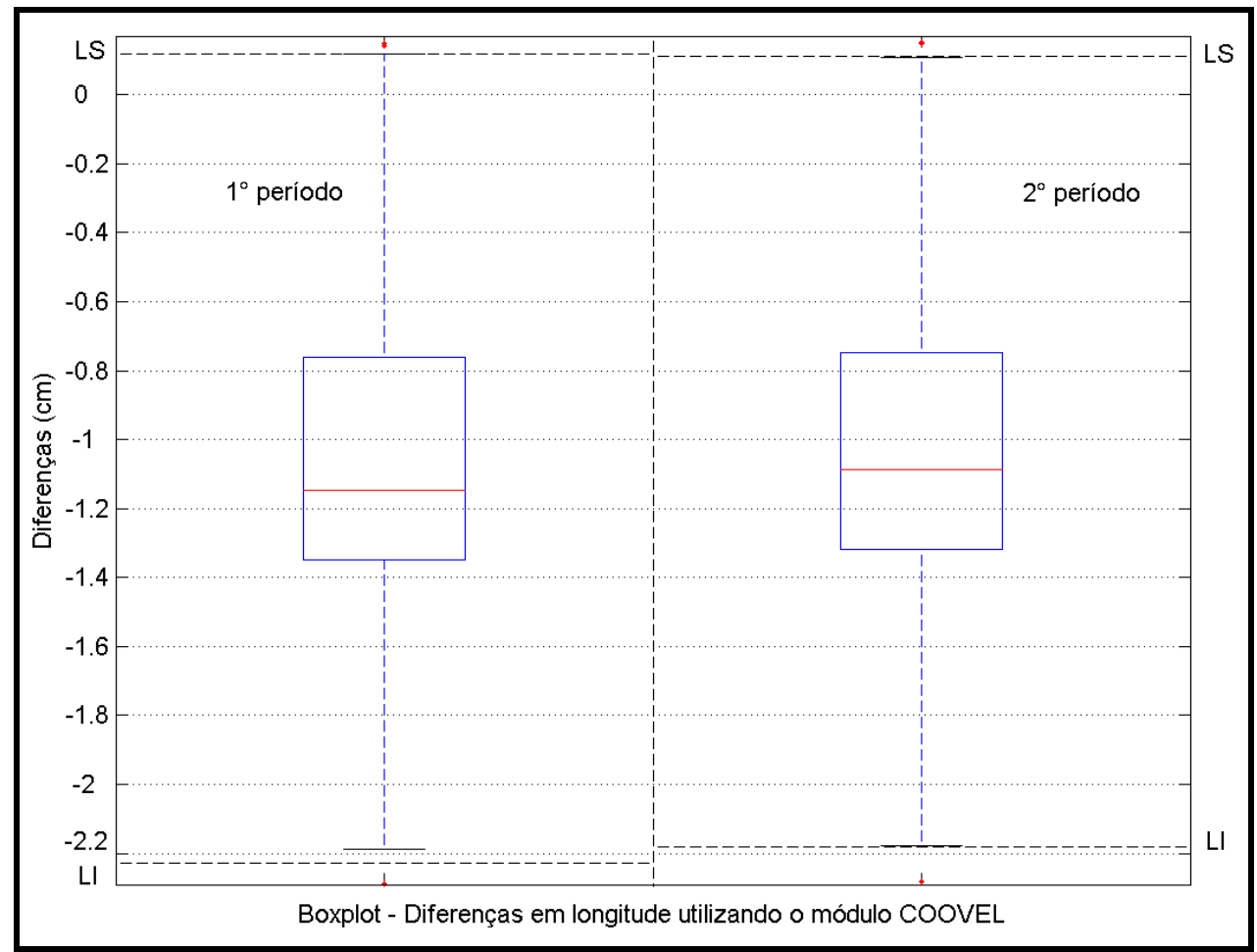

Figura 49: Boxplot das diferenças diárias em longitude para os dois períodos.

A Figura 50 mostra em forma de gráfico as diferenças encontradas para longitude em ambos os períodos, sendo apresentada a média móvel para cada período e a linha de tendência. 


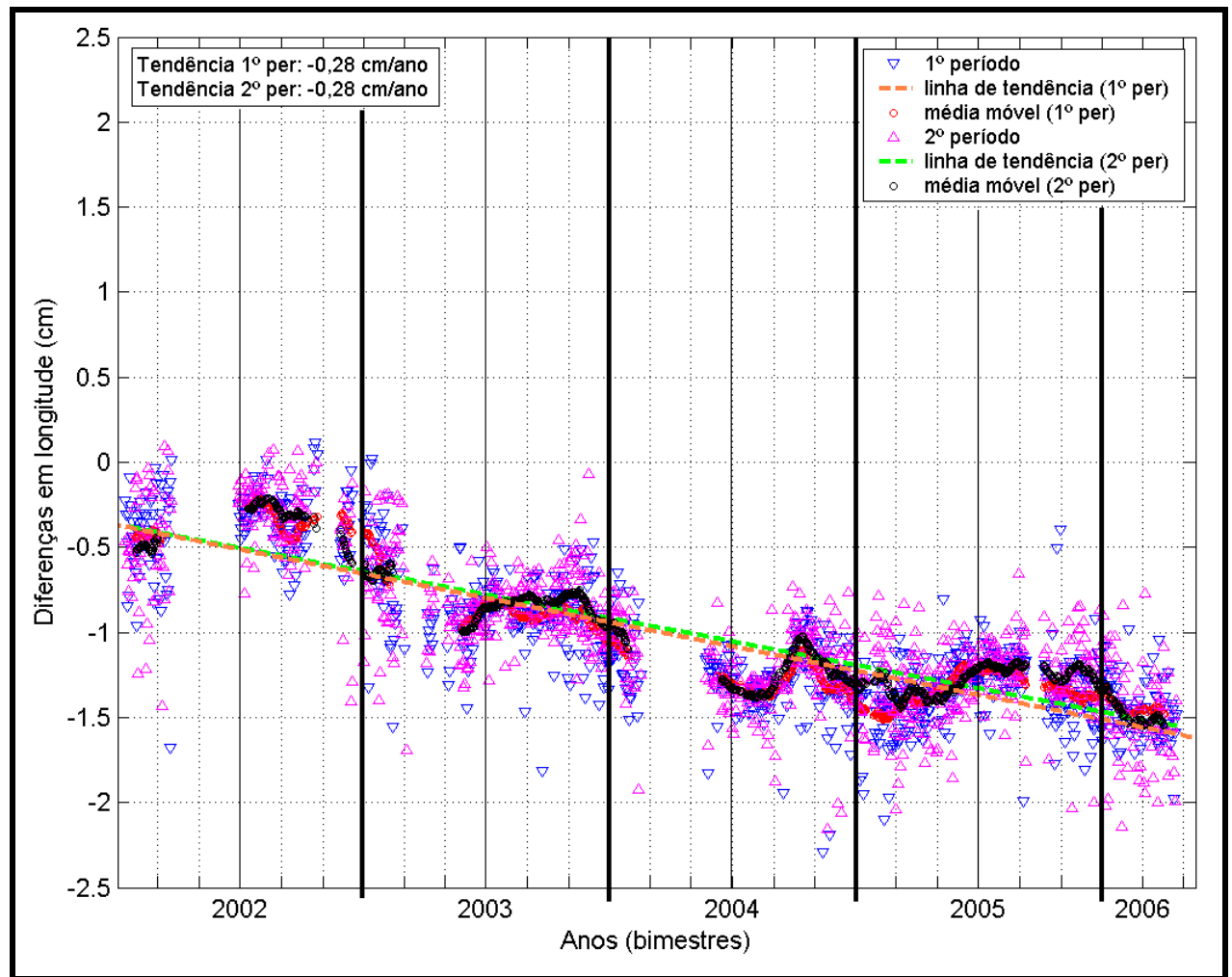

Figura 50: Gráfico das diferenças diárias em longitude utilizando o módulo COOVEL, após filtragem.

\subsection{Altura GeomÉtrica}

No Quadro 27, os resultados das diferenças encontradas para altura geométrica são apresentados em classes, com a respectiva freqüência de ocorrência.

\begin{tabular}{|c|c|c|}
\hline \multirow{2}{*}{ Diferenças (cm) } & \multicolumn{2}{|c|}{ № de arquivos (\% da amostra) } \\
\cline { 2 - 3 } & 10 período & 2ㅇ período \\
\hline$<1$ & $556(51,5 \%)$ & $593(55,1 \%)$ \\
\hline $1 \vdash 2$ & $400(31,7 \%)$ & $329(30,6 \%)$ \\
\hline $2 \vdash 3$ & $59(5,5 \%)$ & $68(6,3 \%)$ \\
\hline $3 \vdash 4$ & $10(0,9 \%)$ & $21(2,0 \%)$ \\
\hline $4 \vdash 5$ & $4(0,4 \%)$ & $5(0,5 \%)$ \\
\hline $5 \vdash 10$ & $3(0,3 \%)$ & $9(0,8 \%)$ \\
\hline $10 \vdash 50$ & $27(2,5 \%)$ & $25(2,3 \%)$ \\
\hline $50 \vdash 100$ & $4(0,4 \%)$ & $2(0,2 \%)$ \\
\hline$>100$ & $16(1,5 \%)$ & $24(2,2 \%)$ \\
\hline
\end{tabular}

Quadro 27 - Valores das diferenças diárias em altura geométrica 
Para representar em forma de gráfico as diferenças para altura geométrica, foi necessário realizar a filtragem dos dados, para eliminação dos outliers. Os valores de corte utilizados na filtragem podem ser vistos no Quadro 28. Na Figura 51 é apresentado o boxplot que apresenta na forma de gráfico os valores constantes no Quadro 28.

\begin{tabular}{|c|c|c|}
\hline \multirow{2}{*}{ Indicativo } & \multicolumn{2}{|c|}{ Altura Geométrica (cm) } \\
\hline & 1ํo período & $2^{\circ}$ período \\
\hline Mínimo & $-991,78$ & $-581,81$ \\
\hline Máximo & 973,13 & 1147,41 \\
\hline 1ㅇ Quartil & 0,26 & 0,34 \\
\hline Mediana & 0,84 & 0,81 \\
\hline 3ํQuartil & 1,41 & 1,39 \\
\hline Limite Inferior & $-1,45$ & $-1,23$ \\
\hline Limite Superior & 3,13 & 2,96 \\
\hline
\end{tabular}

Quadro 28 - Valores calculados para eliminação de outliers em altura geométrica

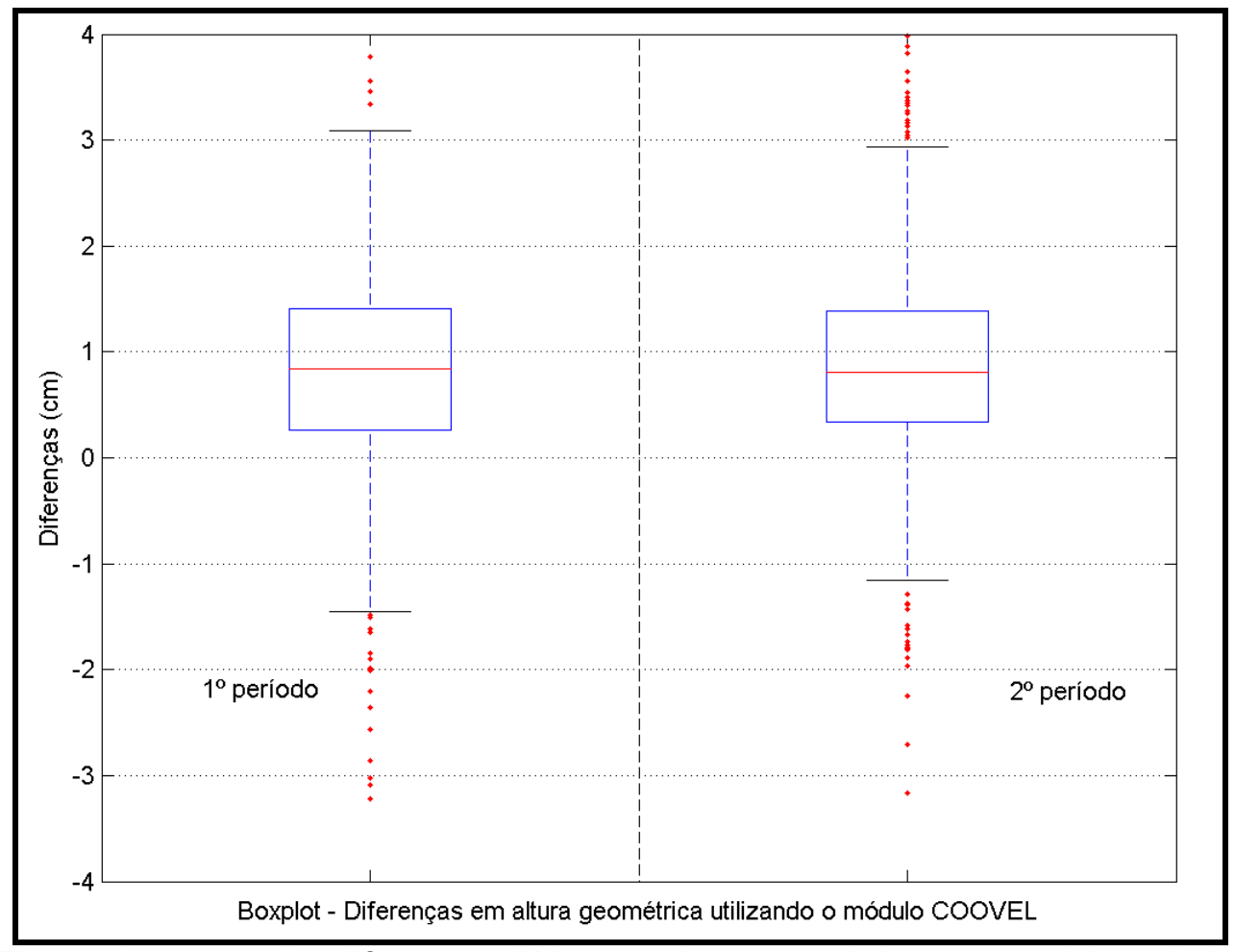

Figura 51: Boxplot das diferenças diárias em altura geométrica para os dois períodos. 
As diferenças calculadas para altura geométrica, após a filtragem dos dados, bem como a média móvel e a linha de tendência são apresentadas na Figura 52.

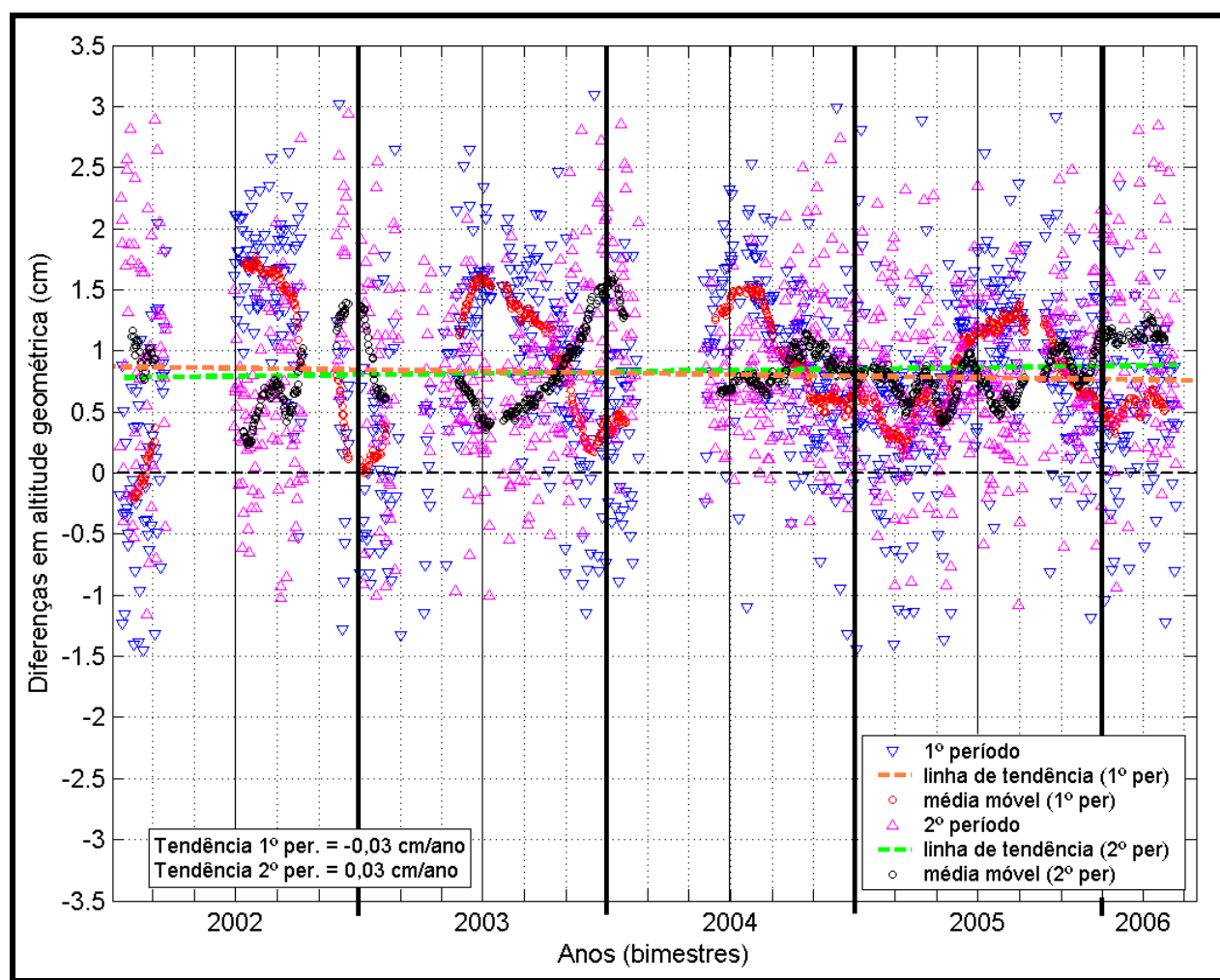

Figura 52: Gráfico das diferenças diárias em altura geométrica utilizando o módulo COOVEL, após filtragem.

\subsubsection{ANÁLISE DOS RESULTADOS}

A partir dos dados colocados nas Figuras 48, 50 e 52 foi possível montar o Quadro 29, com os valores de mínimo, máximo, média e desvio padrão.

O Quadro 30 traz os deslocamentos anuais calculados e seu respectivo desvio padrão para latitude, longitude e altura geométrica, com o processamento utilizando o arquivo de propagação de velocidades. 


\begin{tabular}{|c|c|c|c|c|c|c|}
\hline \multirow{2}{*}{ Indicativo } & \multicolumn{2}{|c|}{ Latitude (cm) } & \multicolumn{2}{|c|}{ Longitude (cm) } & \multicolumn{2}{|c|}{ Alt. Geométrica (cm) } \\
\hline & $1^{\circ}$ per. & $2^{\circ}$ per. & $1^{\circ}$ per. & $2^{\circ}$ per. & $1^{\circ}$ per. & $2^{\circ}$ per. \\
\hline Mínimo & 0,64 & 1,42 & $-2,29$ & $-2,15$ & $-1,45$ & $-1,16$ \\
\hline Máximo & 8,14 & 7,90 & 0,11 & 0,09 & 3,09 & 2,94 \\
\hline Média (x) & 5,01 & 5,00 & 1,05 & 1,02 & 0,81 & 0,83 \\
\hline Desvio $(\sigma)$ & 1,58 & 1,56 & 0,42 & 0,43 & 0,80 & 0,73 \\
\hline
\end{tabular}

Quadro 29 - Diferenças em latitude, longitude e altura geométrica utilizando o módulo COOVEL

\begin{tabular}{|c|c|c|c|}
\hline \multirow{2}{*}{ Direção } & \multicolumn{2}{|c|}{ Tendência anual (cm) } & \multirow{2}{*}{ Diferenças entre } \\
\cline { 2 - 3 } & $\mathbf{1}$ o período & $\mathbf{2}^{\mathbf{o}}$ período & \\
\cline { 2 - 3 } & $\overline{\mathbf{x}} \pm \sigma$ & $\overline{\mathbf{x}} \pm \sigma$ & \\
\hline Latitude & $1,26 \pm 0,25$ & $1,25 \pm 0,26$ & 0,01 \\
\hline Longitude & $-0,28 \pm 0,24$ & $-0,28 \pm 0,27$ & 0,00 \\
\hline Altura Geométrica & $-0,03 \pm 0,80$ & $0,03 \pm 0,73$ & $-0,06$ \\
\hline
\end{tabular}

Quadro 30 - Deslocamentos anuais calculados utilizando o módulo COOVEL

Analisando-se a linha de tendência nos gráficos 46,48 e 50 e os valores do Quadro 30 , observa-se que as 3 componentes apresentaram comportamentos coerentes entre os dois períodos calculados, apesar de a altura geométrica ter proporcionado tendências inversas, apresentando no $1^{\circ}$ período uma diminuição a uma razão de $0,03 \mathrm{~cm} /$ ano e no $2^{\circ}$ período um aumento de $0,03 \mathrm{~cm} / \mathrm{ano}$. Isso se deve ao fato das retas de tendência encontradas para o $1^{\circ}$ e $2^{\circ}$ períodos, para a altura geométrica, estarem praticamente paralelas ao eixo das abscissas, como pode ser visto na Figura 52.

Através deste processamento pode-se avaliar o deslocamento que a estação NEIA vem sofrendo em suas coordenadas devido a movimentação da Placa Sulamericana (Figura 53), isso pode ser observado pelos resultados obtidos em latitude e longitude, que apresentaram um acréscimo por volta de $1,25 \mathrm{~cm} /$ ano e um decréscimo de $0,28 \mathrm{~cm} / a n o$, respectivamente. Para a altura geométrica não foi detectada nenhuma tendência aparente, tanto que a Figura 52 está igual a Figura 46, tendo sua média móvel apresentado o mesmo comportamento do processamento anterior. 


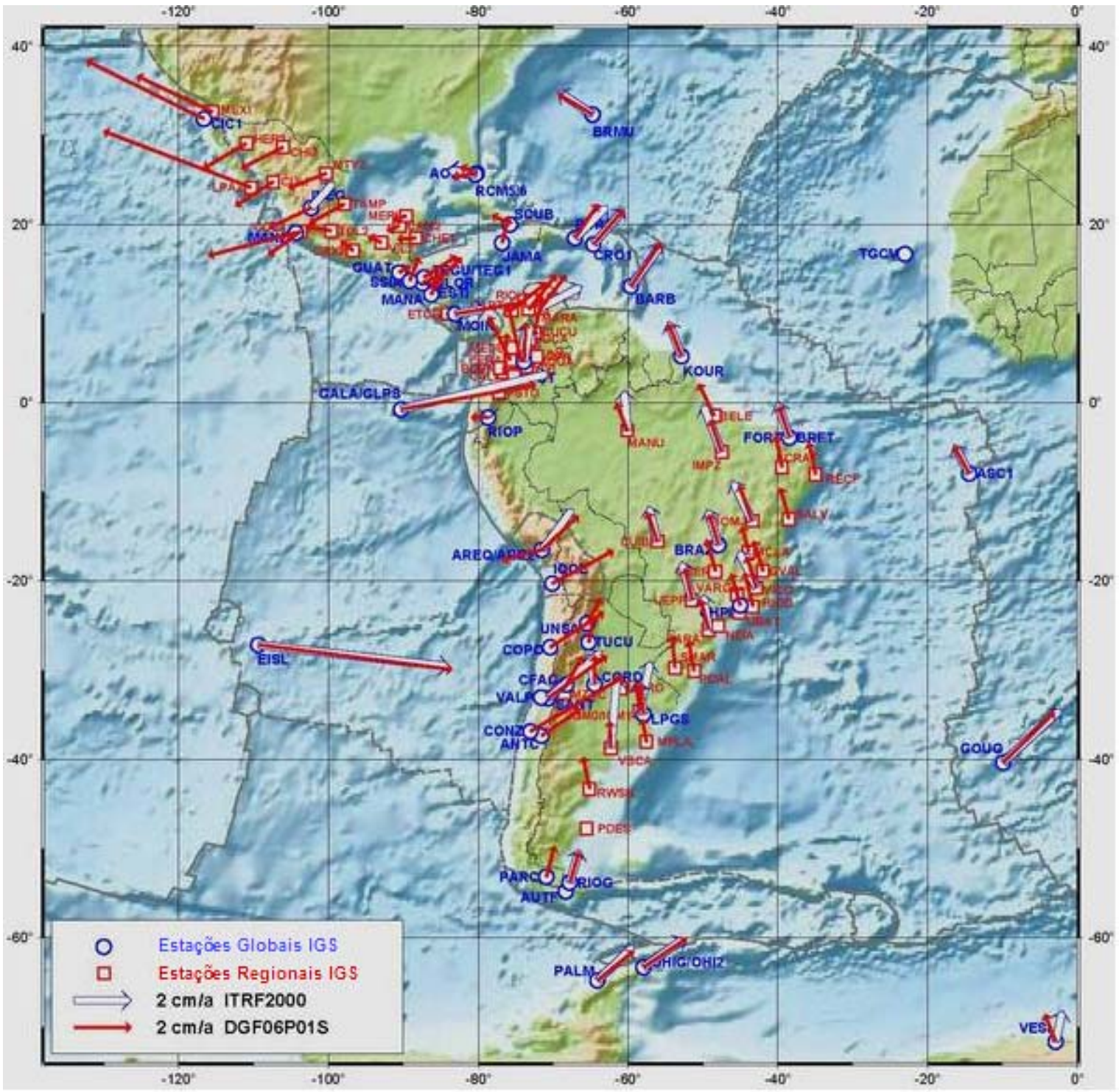

Figura 53: Movimentação da placa Sul-americana.

Fonte: adaptado de DEUTSCHES GEODÄTISCHES FORSCHUNGSINSTITUT, 2007

A média móvel calculada para a latitude coincidiu exatamente com a linha de tendência. Já para a longitude a média móvel também acompanha a linha de tendência, mas não tão coincidente como na componente anterior. Isto ocorreu devido a dispersão dos pontos, pois os valores em latitude estão muito mais agrupados do que os valores em longitude, o que pode ser percebido observando-se as Figuras 48 e 50.

Os deslocamentos calculados no Quadro 30 indicam que a placa movimenta-se em latitude na direção Norte e em longitude na direção Oeste. A resultante do deslocamento e seu respectivo desvio padrão podem ser calculados utilizando as seguintes equações: 


$$
\begin{aligned}
& \mathrm{R}=\sqrt{(\Delta \text { lat })^{2}+(\Delta \text { long })^{2}} \\
& \sigma_{R}=\sqrt{\left(\sigma_{\text {lat }}\right)^{2}+\left(\sigma_{\text {long }}\right)^{2}}
\end{aligned}
$$

sendo:

$\mathrm{R}$ - o valor da resultante;

$\Delta$ lat - o deslocamento em latitude;

$\Delta$ long - o deslocamento em longitude;

$\sigma_{R}$ - o desvio padrão da resultante;

$\sigma_{l a t}$ - o desvio padrão para latitude;

$\sigma_{\text {long }}$ - o desvio padrão para longitude.

O valor calculado para a resultante é de $1,28 \mathrm{~cm}$ com desvio padrão de 0,36 $\mathrm{cm}$, sendo que o deslocamento anual vai à direção Noroeste (NO). A Figura 54 ilustra graficamente o vetor resultante de deslocamento da estação NEIA.

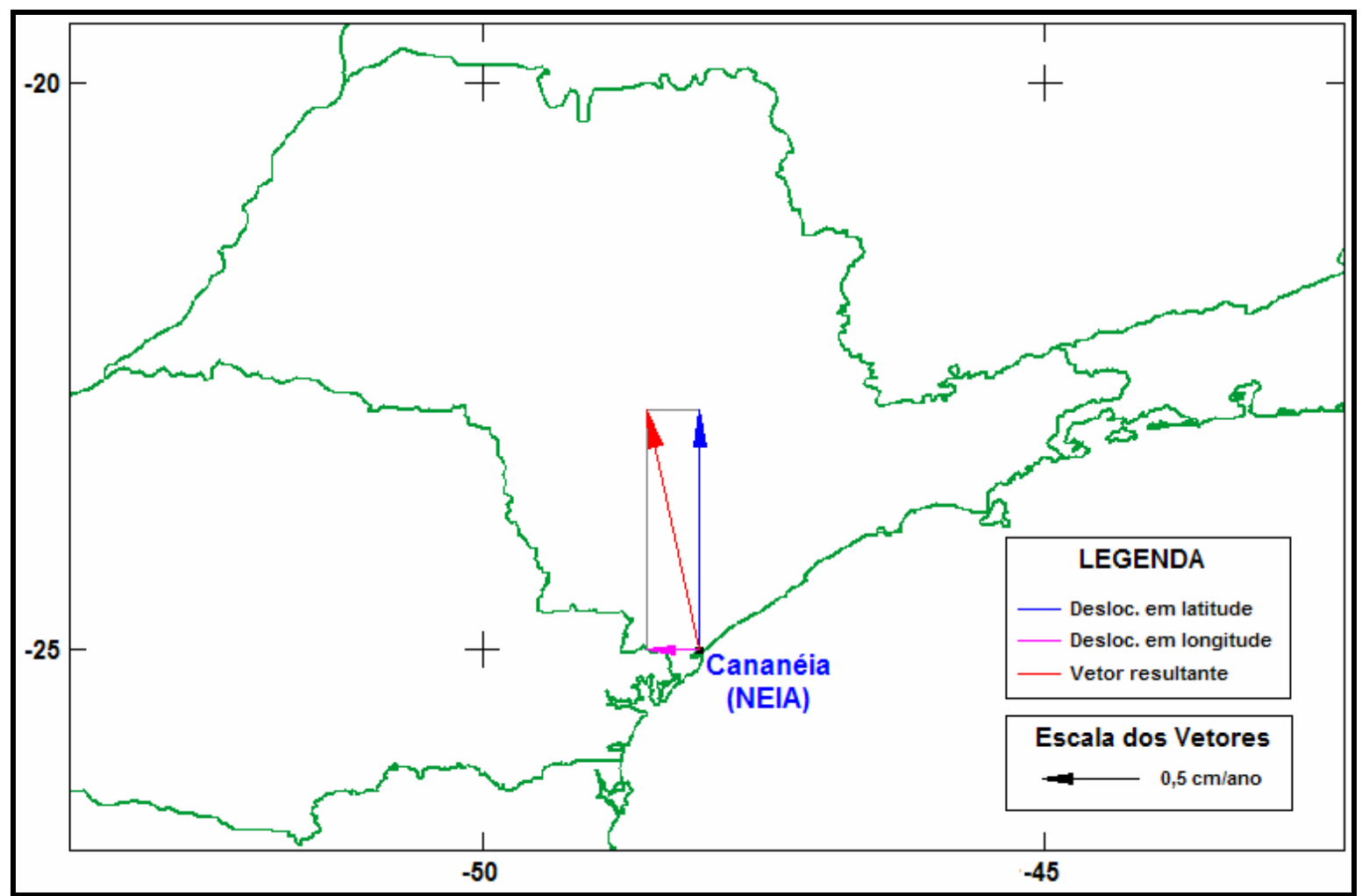

Figura 54: Vetor resultante do deslocamento. 


\subsection{COMPARAÇÃO ENTRE O PROCESSAMENTO UTILIZANDO O PROGRAMA BERNESE E O PROCESSAMENTO UTILIZANDO O SERVIÇO AUSPOS}

Neste item serão comparados os resultados de deslocamento calculados para latitude $(\varphi)$, longitude (I) e altura geométrica (h) (Quadro 31) utilizando o serviço de processamento on-line AUSPOS com os resultados processados pelo programa Bernese V5.0 utilizando o módulo COOVEL.

Deve-se observar que os períodos comparados são distintos, no Bernese foi processada a série de dados de jan./2002 a abr./2006, enquanto no AUSPOS foram processados apenas os dados dos anos de 2003 e 2004.

\begin{tabular}{|c|c|c|c|c|c|c|}
\hline \multirow{4}{*}{ Direção } & \multicolumn{4}{|c|}{ Tendência anual (cm) } & \multirow{3}{*}{\multicolumn{2}{|c|}{$\begin{array}{l}\text { Diferenças entre } \\
\text { os períodos }(\mathrm{cm})\end{array}$}} \\
\hline & \multicolumn{2}{|c|}{ AUSPOS } & \multicolumn{2}{|c|}{ BERNESE } & & \\
\hline & 1o per. & $2^{\circ}$ per. & 1o per. & $2^{\circ}$ per. & & \\
\hline & $\bar{x} \pm \sigma$ & $\bar{x} \pm \sigma$ & $\bar{x} \pm \sigma$ & $\bar{x} \pm \sigma$ & 1ㅇp. & 2o per. \\
\hline Latitude & $1,06 \pm 0,71$ & $1,00 \pm 0,62$ & $1,26 \pm 0,25$ & $1,25 \pm 0,26$ & 0,20 & 0,25 \\
\hline Longitude & $0,10 \pm 1,65$ & $-0,11 \pm 1,12$ & $-0,28 \pm 0,24$ & $-0,28 \pm 0,27$ & $-0,38$ & $-0,17$ \\
\hline $\begin{array}{c}\text { Alt. } \\
\text { Geométrica }\end{array}$ & $-0,46 \pm 2,47$ & $-0,64 \pm 2,01$ & $-0,03 \pm 0,80$ & $0,03 \pm 0,73$ & 0,43 & 0,61 \\
\hline
\end{tabular}

Quadro 31 - Comparação entre os deslocamentos anuais calculados (BERNESE X AUSPOS)

Através dos dados do Quadro 31 é possível observar que, se aplicarmos o valor do desvio padrão aos valores de deslocamento calculados, todos estão coerentes para o nível de incerteza determinado.

Ao observar apenas os valores de deslocamento em longitude, sem utilizar o desvio padrão, fica confirmado por ambos os períodos processados pelo Bernese, e pelo segundo período do AUSPOS que o sentido do deslocamento da componente é para a direção Oeste.

Além disso, observando-se os gráficos de altura geométrica do AUSPOS (Figura 40) e dos dois processamentos do programa Bernese (Figuras 46 e 52), verifica-se que eles estão em posição oposta em relação ao eixo das abscissas. 
Pode-se observar também, pelo Quadro 31, que as diferenças calculadas para - AUSPOS estão mais dispersas do que as calculadas utilizando o programa Bernese, devido ao desvio padrão do serviço AUSPOS ser maior.

\subsection{COMPARAÇÃO ENTRE O PROCESSAMENTO REALIZADO NESTA PESQUISA E O PROCESSAMENTO REALIZADO PELO IBGE}

O IBGE, como o órgão responsável pela Geodésia no Brasil, realiza o monitoramento sistemático de todas as estações SIRGAS, função desempenhada através de sua Coordenação de Geodésia.

Utilizando o programa Bernese V5.0, é realizado o processamento das estações, empregando como referência a estação BRAZ (Brasília/DF). O processamento é realizado diariamente, e semanalmente, são combinados os resultados processados naquela semana, gerando as coordenadas semanais para cada uma das estações integrantes do SIRGAS.

São apresentados nas Figuras 55, 56 e 57, e no Quadro 32 os valores calculados pela diferença entre as coordenadas calculadas pelo IBGE e as coordenadas fiduciais da estação NEIA.

O intervalo de tempo comparado neste item é diferente, no Bernese foram processados os dados da estação NEIA de jan./2002 a abr./2006, enquanto que, pelo IBGE, foram processados apenas os dados dos anos de 2004 e 2005. 


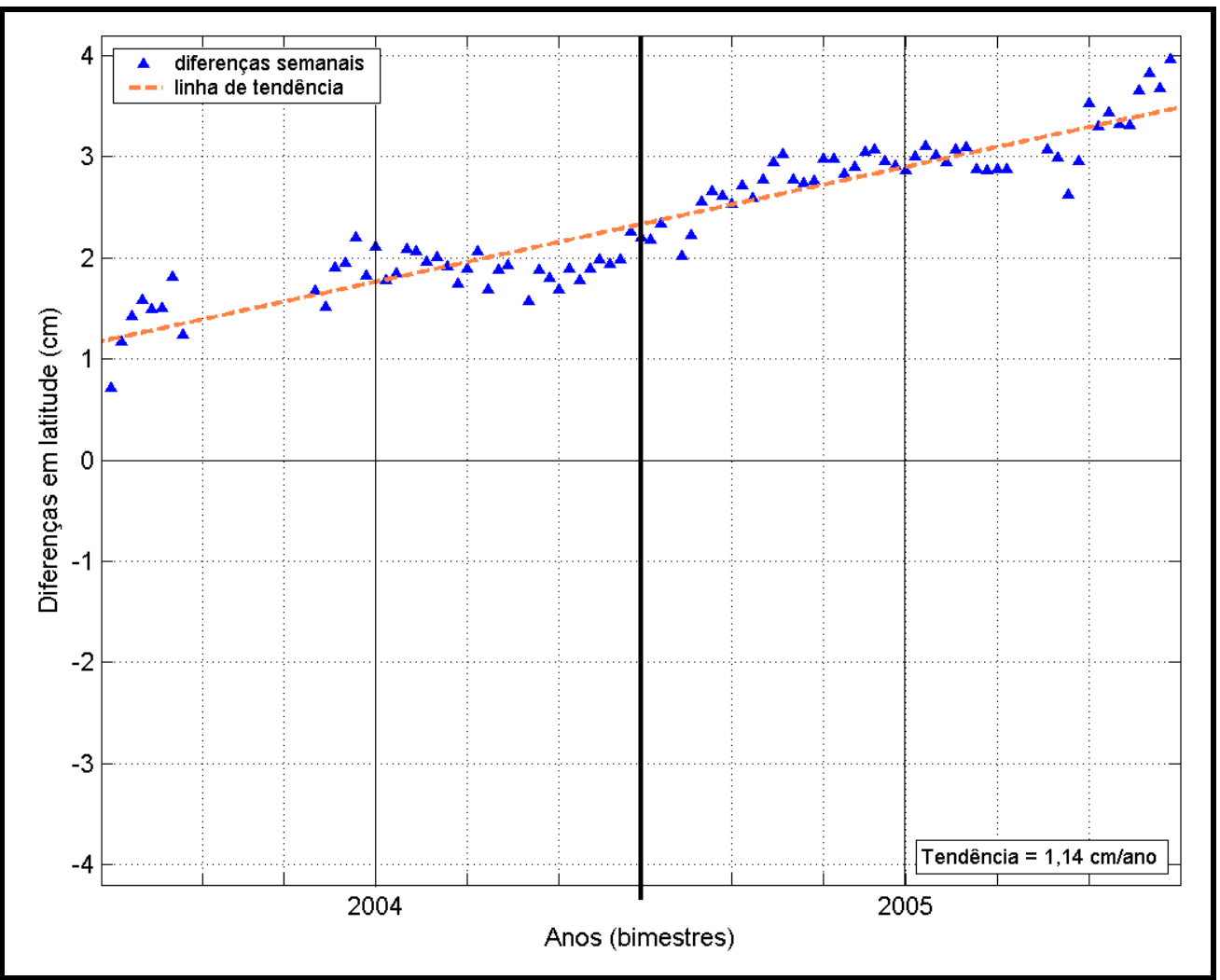

Figura 55: Gráfico das diferenças semanais em latitude (IBGE).

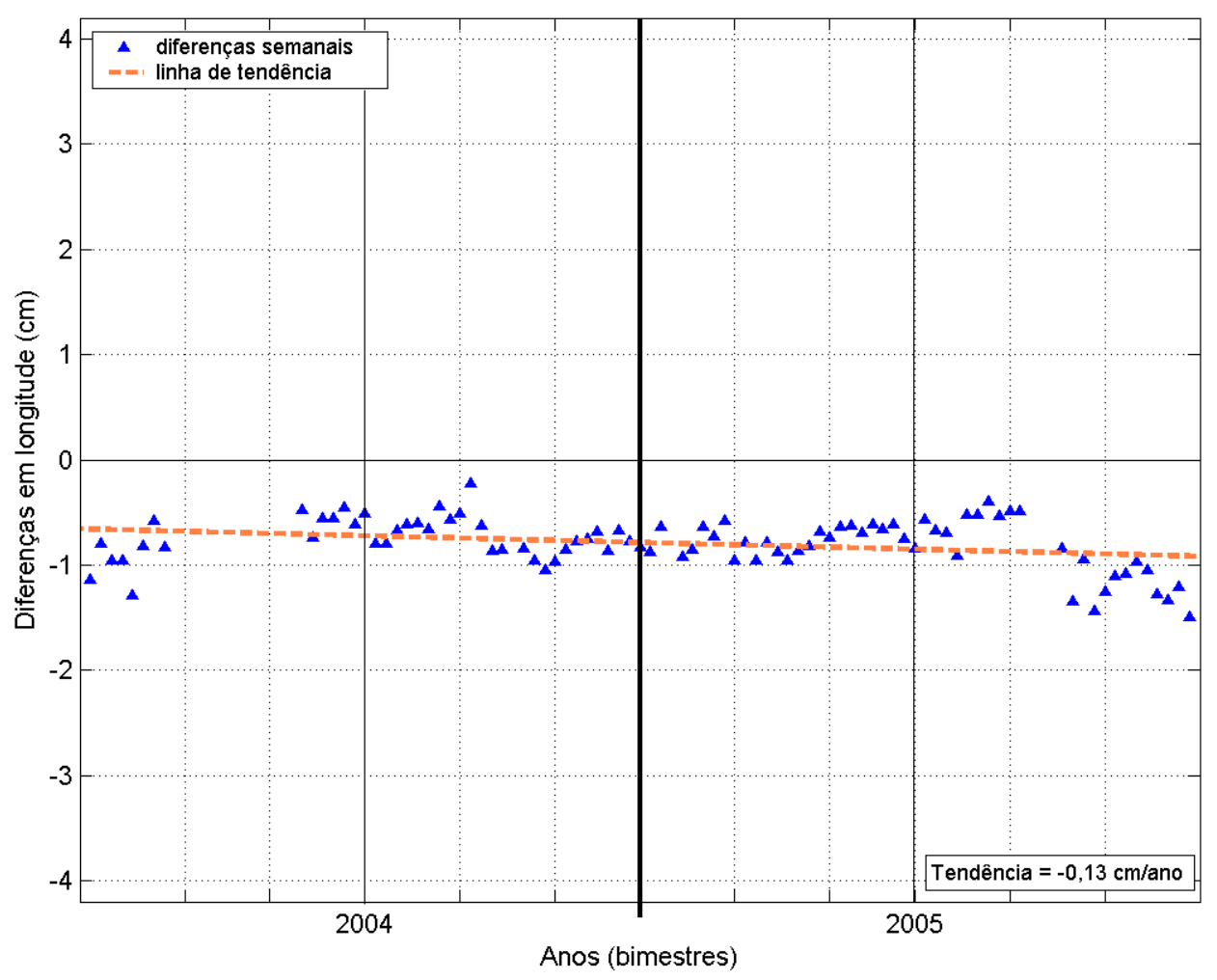

Figura 56: Gráfico das diferenças semanais em longitude (IBGE). 


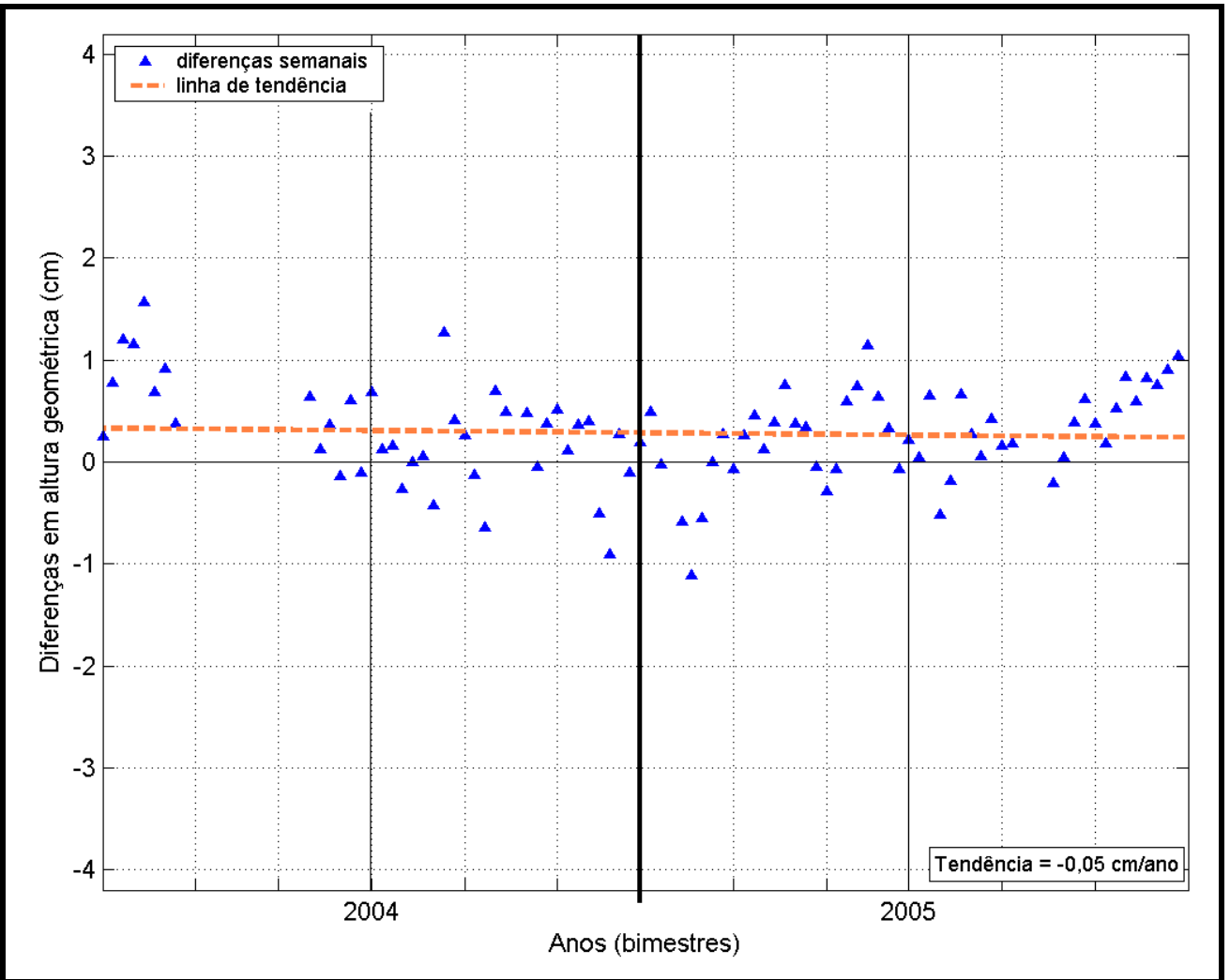

Figura 57: Gráfico das diferenças semanais em altura geométrica (IBGE).

\begin{tabular}{|c|c|c|c|c|c|}
\hline \multirow{4}{*}{ Direção } & \multicolumn{3}{|c|}{ Tendência anual (cm) } & \multirow{3}{*}{\multicolumn{2}{|c|}{$\begin{array}{c}\text { Diferenças } \\
\text { entre os } \\
\text { períodos }(\mathbf{c m})\end{array}$}} \\
\hline & \multirow{3}{*}{$\begin{array}{l}\text { IBGE } \\
\bar{x} \pm \sigma\end{array}$} & \multicolumn{2}{|c|}{ Nesta pesquisa (BERNESE) } & & \\
\hline & & $1^{\circ}$ per. & $2^{\circ}$ per. & & \\
\hline & & $\bar{x} \pm \sigma$ & $\bar{x} \pm \sigma$ & $1^{\circ}$ per. & $2^{\circ}$ per. \\
\hline Latitude & $1,14 \pm 0,24$ & $1,26 \pm 0,25$ & $1,25 \pm 0,26$ & 0,12 & 0,11 \\
\hline Longitude & $-0,13 \pm 0,23$ & $-0,28 \pm 0,24$ & $-0,28 \pm 0,27$ & $-0,15$ & $-0,15$ \\
\hline A. Geométrica & $-0,05 \pm 0,48$ & $-0,03 \pm 0,80$ & $0,03 \pm 0,73$ & 0,02 & 0,08 \\
\hline
\end{tabular}

Quadro 32 - Comparação entre os deslocamentos anuais calculados (Nesta pesquisa (BERNESE) X IBGE)

Deve-se observar que o período dos dados utilizados para o cálculo da tendência é diferente, nesta pesquisa foi processado o período de jan/2002 a abr/2006, e pelo IBGE os resultados são referentes aos anos de 2004 e 2005.

Analisando os valores do Quadro 32, gerados pelo processamento com o programa Bernese utilizando o módulo COOVEL e o realizado pelo IBGE, pode-se observar que as tendências calculadas para cada uma das componentes ficaram bem próximas, demonstrando coerência entre os valores determinados. 
Apesar do arquivo de propagação de velocidades ser apenas utilizado para determinação das coordenadas planimétricas, os gráficos de altura geométrica gerados pelos processamentos do Bernese (nesta pesquisa) e pelo processamento do IBGE ficaram coerentes.

\subsection{COMPARAÇÃO ENTRE O PROCESSAMENTO REALIZADO NESTA PESQUISA E O PROCESSAMENTO REALIZADO PELO DGFI}

O DGFI (Deutsches Geodätisches Forschungsinstitut) é uma instituição alemã que também realiza o monitoramento sistemático de todas as estações SIRGAS e divulga anualmente um relatório onde são apresentados os resultados de todas as estações monitoradas, sendo que, a estação NEIA passou a fazer parte deste processamento apenas à partir do ano de 2006.

O DGFI também utiliza o programa Bernese V5.0, e como o IBGE, realiza o processamento das estações diariamente, combinando os resultados processados naquela semana, gerando as coordenadas semanais para cada uma das estações integrantes do SIRGAS.

Nas Figuras 58, 59 e 60 são apresentados graficamente os valores calculados pela diferença entre as coordenadas calculadas pelo DGFI e as coordenadas fiduciais da estação NEIA, e no Quadro 33, pode-se observar a tendência anual calculada utilizando os dados do DGFI e os dados calculados neste trabalho utilizando o programa Bernese V5.0. O grid apresentado nas Figuras 58, 59 e 60 está definido por quinzenas para não poluir a visualização das mesmas, mas devese perceber que os dados apresentados são semanais.

Deve-se observar que os períodos comparados são diferentes, pois, o DGFI dispunha de apenas um ano de dados (2006), enquanto nesta pesquisa foi processado o período de jan./2002 a abr./2006. 


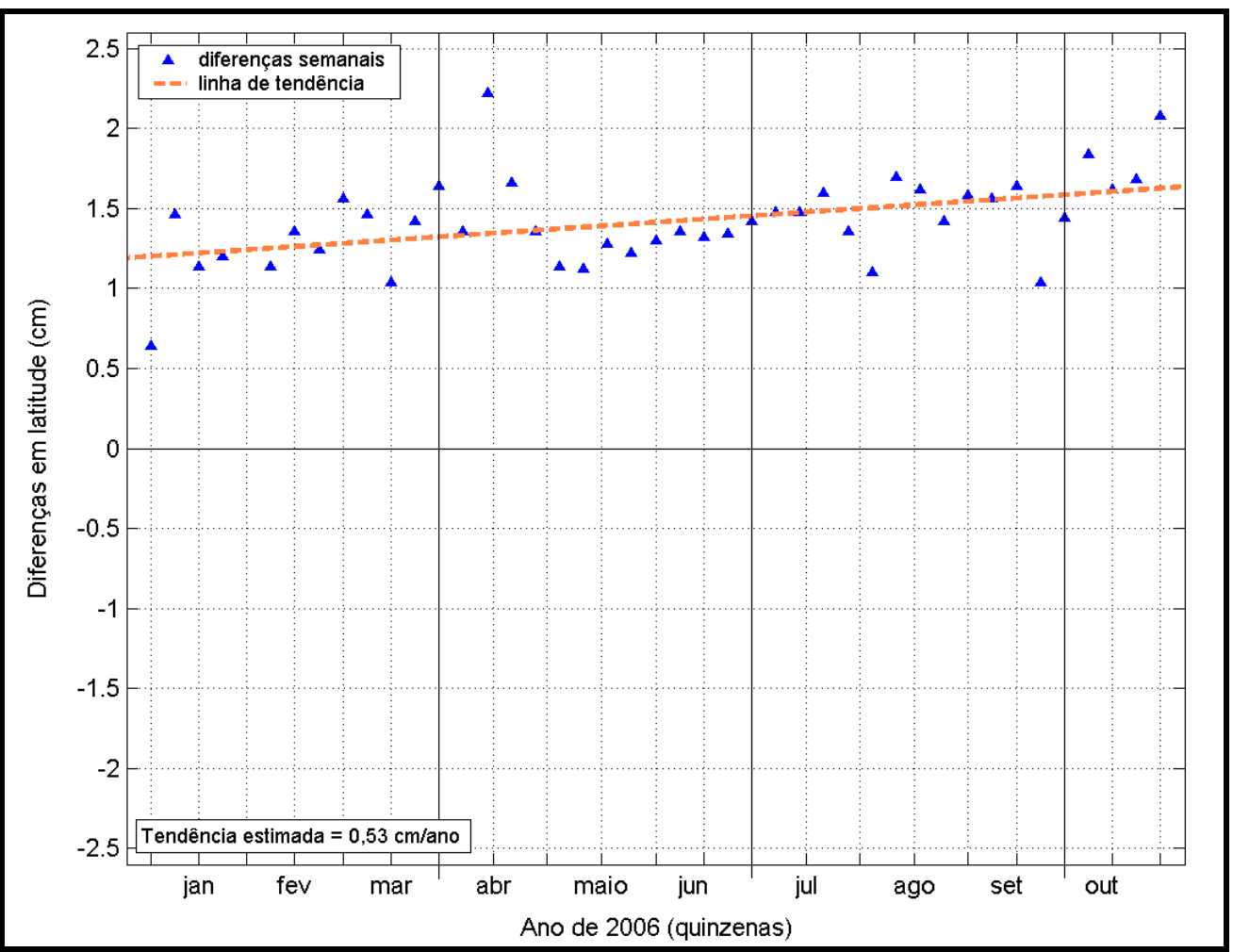

Figura 58: Gráfico das diferenças semanais em latitude (DGFI).

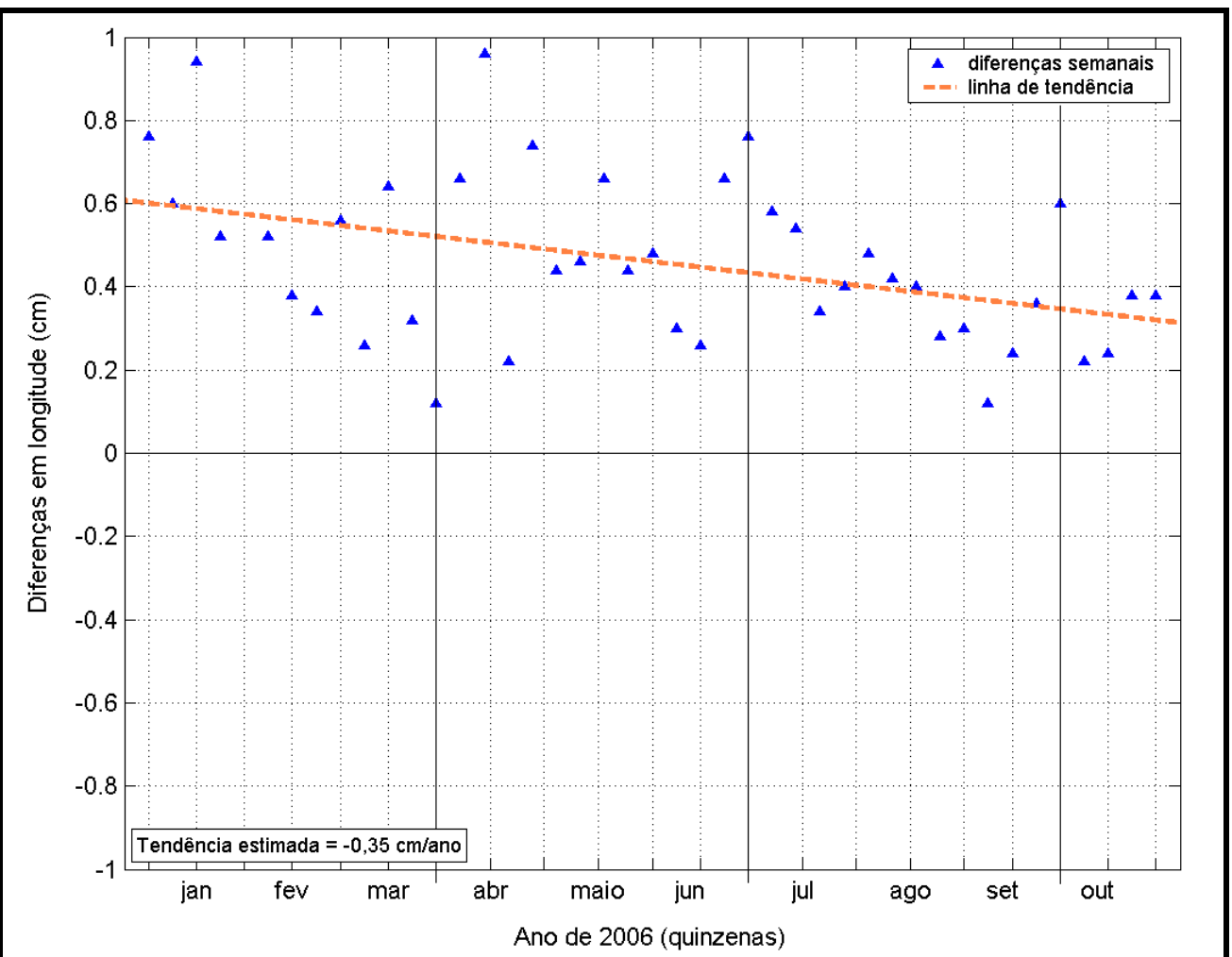

Figura 59: Gráfico das diferenças semanais em longitude (DGFI). 


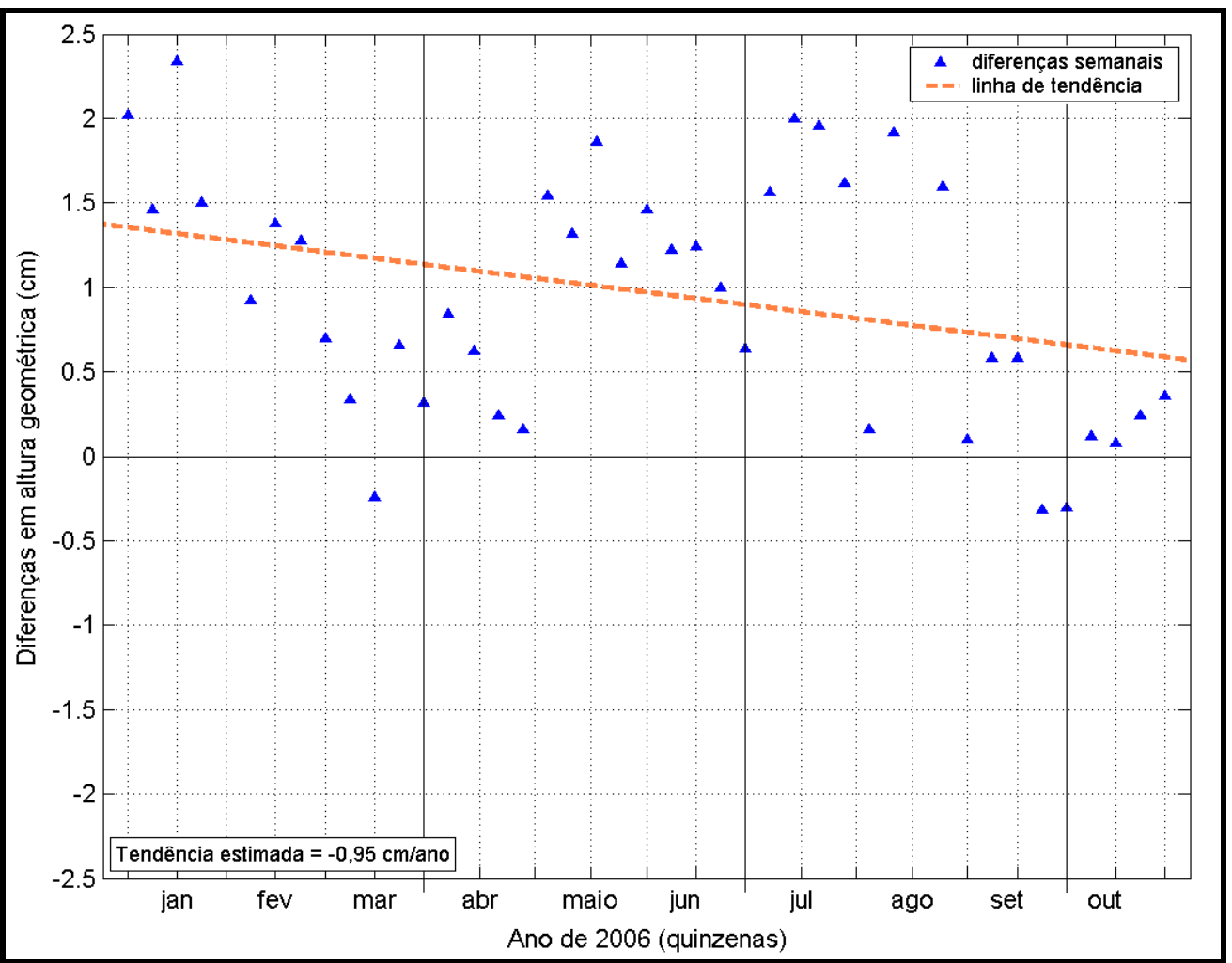

Figura 60: Gráfico das diferenças semanais em altura geométrica (DGFI).

\begin{tabular}{|c|c|c|c|c|c|}
\hline \multirow{4}{*}{ Direção } & \multicolumn{3}{|c|}{ Tendência anual (cm) } & \multirow{3}{*}{\multicolumn{2}{|c|}{$\begin{array}{l}\text { Diferenças } \\
\text { entre os } \\
\text { períodos }(\mathbf{c m})\end{array}$}} \\
\hline & \multirow{3}{*}{$\begin{array}{l}\text { DGFI } \\
\bar{x} \pm \sigma \\
\end{array}$} & \multicolumn{2}{|c|}{ Nesta pesquisa (BERNESE) } & & \\
\hline & & \multirow{2}{*}{$\begin{array}{c}\text { 1o per. } \\
\bar{x} \pm \sigma\end{array}$} & \multirow{2}{*}{$\begin{array}{c}\text { 20 per. } \\
\bar{x} \pm \sigma\end{array}$} & & \\
\hline & & & & $1^{\circ}$ per. & $2^{\circ}$ per. \\
\hline Latitude & $0,53 \pm 0,25$ & $1,26 \pm 0,25$ & $1,25 \pm 0,26$ & 0,73 & 0,72 \\
\hline Longitude & $-0,35 \pm 0,18$ & $-0,28 \pm 0,24$ & $-0,28 \pm 0,27$ & 0,07 & 0,07 \\
\hline A. Geométrica & $-0,95 \pm 0,71$ & $-0,03 \pm 0,80$ & $0,03 \pm 0,73$ & 0,92 & 0,98 \\
\hline
\end{tabular}

Quadro 33 - Comparação entre os deslocamentos anuais calculados (Nesta pesquisa (BERNESE) $X$ DGFI)

Analisando-se os valores do Quadro 33, gerados pelo processamento com o programa Bernese e o realizado pelo DGFI, pode-se observar que as tendências calculadas para cada uma das componentes tiveram o mesmo comportamento, na direção Norte $(\mathrm{N})$ para latitude e na direção Oeste $(\mathrm{O})$ para longitude. Os valores de tendência calculados para longitude estão bem próximos, mas os calculados para latitude ficaram distantes, sendo que, os valores calculados neste trabalho apresentaram uma tendência maior que duas vezes a tendência apresentada pelo DGFI. Isso pode ter ocorrido devido à pequena série calculada pelo DGFI, pois, 
quanto mais longo for o período de observações GPS os resultados serão mais confiáveis, sendo que, alguns pesquisadores consideram o período de 5 anos apropriado para iniciar estudos de Geodinâmica (COSTA, 2001).

No caso das diferenças em altura geométrica, a tendência calculada pelo DGFI apresentou uma diminuição ao longo da série, igual ao primeiro período calculado neste trabalho e igual ao valor calculado pelo IBGE. O que chamou a atenção, foi que a tendência calculada pelo DGFI $(-0,95 \mathrm{~cm} / \mathrm{ano})$ ficou muito discrepante em relação às tendências calculadas neste trabalho $(-0,03 \mathrm{~cm} / \mathrm{ano})$ e pelo IBGE $(-0,05$ cm/ano), porém, como o arquivo de propagação de velocidades é apenas planimétrico, não há como afirmar e fazer comparações com precisão para a componente altimétrica. 


\section{CONCLUSÕES E RECOMENDAÇÕES}

Durante o desenvolvimento desta pesquisa, foram analisados alguns índices para avaliar a qualidade dos dados GPS coletados pela estação NEIA, a fim de orientar os usuários sobre o funcionamento da mesma. Além disso, o processamento dos dados possibilitou verificar a estabilidade da estação e a movimentação que a mesma sofre devido ao deslocamento da placa Sul-americana.

Como forma de contribuição desta pesquisa, a partir dos resultados e análises geradas, são apresentadas as conclusões e recomendações com o objetivo de ponderar sobre as ferramentas e os experimentos realizados.

\subsection{CONCLUSÕES}

A partir das análises realizadas sobre os resultados gerados pelo programa de pré-processamento TEQC (item 4.1), conclui-se que:

- Os índices de horas rastreadas e observações coletadas apresentados mostraram que o funcionamento da estação é satisfatório, apesar das falhas e perdas de arquivos. Através dos gráficos gerados foi possível verificar que a estação possuía muitas perdas de dados no início de seu funcionamento, e que, a partir do segundo semestre de 2004, as perdas passaram a ser muito menos constantes;

- Com relação aos índices de perdas de ciclos (item 4.1.1.3), pôde ser visto que as perdas não são muitas, mas podem ser minimizadas retirando objetos que possam obstruir o horizonte de visada da antena como, por exemplo, a copa de árvores grandes próximas à estação;

- Os valores de multicaminho (MP1 e MP2) apresentaram-se coerentes quando comparados aos valores calculados para as estações da RBMC que possuem o mesmo tipo de receptor. Atualmente, algumas estações da RBMC já contam com receptores mais modernos, que possuem programas internos capazes de minimizar os efeitos de multicaminho, 
fazendo com que este valor seja bastante reduzido. Os valores apresentados para MP2 são sempre maiores do que os apresentados para MP1, pois a onda portadora L2 possui comprimento de onda maior (freqüência menor) que a onda portadora L1 estando mais suscetível a interferências. A causa da mudança brusca de comportamento detectada em L1, entre os anos de 2003 e 2004, não foi encontrada, mas, pode ter sido causada por: troca da antena, problemas de recepção no centro de fase da onda portadora $L 1$, água acumulada no centro eletrônico da antena ou a retirada de algum objeto que causava o multicaminho e que possa ter sido colocado novamente próximo à antena.

Em relação às ferramentas utilizadas no processamento dos dados e a análise dos resultados gerados pelas mesmas, pôde-se concluir que:

- As ferramentas de processamento on-line (itens 4.2 e 4.3) são de fácil utilização, mas ainda dependem de mais testes para que possam ser aplicadas corretamente por todos os usuários do GPS;

- Através da análise dos resultados do serviço AUSPOS foi possível observar que a estação NEIA vem sofrendo uma variação em suas coordenadas ao longo do tempo, devido ao movimento da placa Sulamericana;

- O programa Bernese V5.0 apresentou-se como uma boa ferramenta para o processamento dos dados GPS;

- O primeiro processamento realizado utilizando o programa Bernese, não possibilitou identificar movimentação na estação, mas permitiu verificar que a mesma não sofre nenhum tipo de movimento em relação à estação de referência. A média móvel auxiliou na identificação de movimentos sazonais em latitude e longitude, possivelmente causados pelas estações do ano, e em altura geométrica permitiu verificar a movimentação contrária entre os dois períodos analisados, caracterizando a influência de maré terrestre e/ou carga oceânica;

- Na análise dos resultados do segundo processamento utilizando o programa Bernese V5.0, com o módulo COOVEL para propagar as coordenadas da estação de referência, foi possível identificar 
movimentação na estação NEIA, nas componentes latitude e longitude. A altura geométrica não apresentou nenhuma mudança em relação ao primeiro processamento e manteve o mesmo comportamento. Isso se deve ao fato do modelo propagar a velocidade apenas para as componentes horizontais. Através desta análise, também foi possível verificar que a estação NEIA vem sofrendo uma alteração em suas coordenadas, devido à movimentação da Placa Sul-americana. Isto pode ser comprovado pelos resultados obtidos em latitude, que apresentou movimentação na direção Norte $(\mathrm{N})$ por volta de $1,25 \mathrm{~cm} /$ ano com desvio de aproximadamente $0,25 \mathrm{~cm} / \mathrm{ano}$, e em longitude, apresentando movimentação de $0,28 \mathrm{~cm} /$ ano com desvio padrão de 0,26 cm/ano na direção Oeste $(\mathrm{O})$, resultando em uma movimentação anual da ordem de $1,3 \mathrm{~cm} /$ ano com desvio padrão de $0,4 \mathrm{~cm} / \mathrm{ano}$, sendo que, o deslocamento anual tem direção predominante para Noroeste (NO).

\subsection{RECOMENDAÇÕES}

Embasado nos resultados gerados e nas análises realizadas é possível apresentar as seguintes recomendações:

- Realizar o processamento dos dados da estação reduzindo o tempo gradativamente para 6 horas, 2 horas e 1 hora, a fim de verificar quais movimentos de tendência podem ser observados, principalmente os efeitos sazonais em latitude e longitude, e os efeitos de maré que afetam a componente vertical;

- Criar condições para geração e divulgação sistemática dos indicativos gerados pelo TEQC para todas as estações da RBMC, atuais e futuras;

- Divulgar os índices calculados para as estações da RBMC através da internet, sendo que, atualmente, O IBGE já vem tomando providências para adotar este procedimento como padrão;

- A estação NEIA encontra-se no litoral, e a serra próxima a mesma tornase uma obstrução natural que não pode ser evitada e nem eliminada, 
portanto, a realização de um controle sistemático no entorno da estação se faz necessário para evitar o aumento das fontes de obstrução do sinal GPS, efeito que pode ser controlado, principalmente, com a poda sistemática das árvores;

- O receptor GPS utilizado na estação NEIA já tem quase dez anos de uso, e a troca do mesmo por um modelo mais novo, acarretaria em melhor performance e confiabilidade da estação;

- Uma conexão de alta velocidade (banda larga) permitiria maior controle da estação remotamente, além de possibilitar que os dados fossem transferidos ao IBGE com maior rapidez.

Para futuros trabalhos que venham a ser desenvolvidos, recomenda-se:

- Estudar e utilizar os vários modelos de correção (ionosfera, troposfera, maré e carga oceânica) disponíveis no programa Bernese para processar os dados, e comparar os resultados analisando quais são os melhores modelos para serem aplicados à estação;

- Estudar e utilizar outras ferramentas científicas de processamento de dados GPS, como o GIPSY-OASIS e o GAMIT, a fim de comparar resultados e ver se os resultados gerados pelas ferramentas utilizadas são compatíveis;

- Integrar os dados da estação NEIA com os dados do marégrafo, localizado na própria base do IO-USP, com o intuito de realizar estudos sobre a componente altimétrica;

- Utilizar os dados da estação NEIA conjuntamente aos dados da estação metereológica, situada na própria base do IO-USP, para realizar estudos referentes ao comportamento da troposfera na região da estação;

- Realizar novos testes utilizando os serviços de processamento on-line com objetivo de avaliar melhor em quais tipos de trabalhos os mesmos podem ser utilizados;

- Analisar, a mudança brusca ocorrida com o multicaminho em L1 (Figuras 27 e 28) entre os anos de 2003 e 2004, na tentativa de detectar a real fonte do efeito, podendo ser, através de documentos que apresentem o histórico da estação ou de informações dos funcionários da base que 
tenham acompanhado a estação desde a sua instalação e possam dar detalhes sobre possíveis mudanças;

- Processar os dados GPS utilizando o método PPP, e compará-los aos gerados utilizando o método relativo. Com o método de "Posicionamento Preciso por Ponto" seria eliminada a incerteza devido à distância da linha de base, além de ser teoricamente mais fácil de identificar o movimento da estação, pois o cálculo da coordenada será absoluto e não relativo à outra estação, e não dependerá de um movimento de propagação de velocidades para a identificação do deslocamento.

\subsection{PERSPECTIVAS FUTURAS}

O objetivo principal desta dissertação consistiu em analisar a qualidade dos dados GPS da estação NEIA. Isso se faz necessário, pois, devido a grande popularização do GPS, o número de estações permanentes vem crescendo de maneira muito rápida, e a tendência é que isso aumente significativamente nos próximos anos.

Atualmente, o IBGE, como órgão oficial que regula a Geodésia no Brasil, conta com 24 estações permanentes, e em 2006 firmou um convênio com o Instituto de Colonização e Reforma Agrária (INCRA), que prevê a instalação de mais 56 novas estações nos próximos anos, além da troca de equipamentos nas outras já existentes, totalizando 80 estações em funcionamento no território nacional. Isso prova a necessidade de se ter os indicativos de qualidade destas estações disponíveis a toda comunidade, a fim de orientar os usuários sobre a utilização das mesmas, além da realização do monitoramento sistemático do deslocamento das estações da RBMC, tarefa que já vem sendo desempenhada pelo IBGE há alguns anos. 


\section{REFERÊNCIAS}

AKOS, D. M. et al. GNSS album: images and spectral of the new GNSS signals. Inside GNSS, Canadá, v. 1, n. 4, p. 46-56, maio/jun. 2006.

ASTRONAUTIX. Glonass. Artigo n. 11F654. Disponível em: <http://www.astronautix.com/craft/glonass.htm>. Acesso em: 12 mar. 2006.

AUSTRALIAN SURVEYING AND LAND INFORMATION GROUP'S ONLINE GPS PROCESSING SYSTEM. AUSPOS. Disponível em: <http://www.ga.gov.au/>. Acesso em: 20 maio 2005.

BLACK, H. D.; EISNER, A. Correcting satellite doppler data for tropospheric effects. Journal of Geophysical Research, Washington, DC, v. 83, n. B4, p. 1825-1828, sept. 1984.

BRUYNINX, C. The global positioning system: present status and modernization plans. In: GNSS Workshop, 2002, Brussels, Belgium. Proceedings... Brussels, Belgium: Royal Observatory of Belgium. Disponível em:

<http://www.gps.oma.be/publications/2002/modern.pdf>. Acesso em: 10 out. 2006.

CAMARGO, P. O. Modelo regional da ionosfera para uso em posicionamento com receptores GPS de uma freqüência. 1999. $191 \mathrm{f}$. Tese (Doutorado) Universidade Federal do Paraná, Curitiba, 1999.

CASTRO, A. L. P. Nivelamento através do GPS: avaliação e proposição de estratégias. 2002. 174 f. Dissertação (Mestrado) - Faculdade de Ciências e Tecnologia, Universidade Estadual Paulista, Presidente Prudente, 2002.

CHANG, X. -W.; YANG, X.; ZOU, T. MLAMBDA: a modified LAMBDA method for integer least-squares estimation. GNSS Solutions, v. 79, n. 9, p. 552-565, dez. 2005.

COLLINS, J.P. An overview of GPS inter-frequency carrier phase combinations. UNB/GSD. out.1999. Disponível em:

<http://gauss.gge.unb.ca/papers.pdf/L1L2combinations.collins.pdf>. Acesso em: 23 nov. 2006. 
COORDINATIONAL SCIENTIFIC INFORMATION CENTER. Glonass center. Disponível em: <http://www.glonass-center.ru/frame e.html>. Acesso em: 13 mar. de 2006.

COSTA, S. M. A. Estimativa do Campo de Velocidades a partir das Estações da RBMC. XX Congresso Brasileiro De Cartografia. Porto Alegre, 2001. Disponível em: $<$ http://www.ibge.gov.br/home/geociencias/geodesia/default artigos.shtm?c=18>. Acesso em: 15 out. 2006.

CREEL, T. et al. New improved GPS: the legacy accuracy improvement initiative, GPS World, Duluth, v. 17, n. 03, p. 20-31, mar. 2006.

CRUSTAL DYNAMICS DATA INFORMATION SYSTEM. NASA's archive of space geodesy data. Disponível em: <http://cddis.nasa.gov>. Acesso em: 28 ago. 2006.

DELFT UNIVERSITY OF TECHNOLOGY. Faculty of Aerospace Engineering Department of Earth Observation and Space Systems/DEOS - Mathematical Geodesy and Positioning. Disponível em:

$<$ http://www.Ir.tudelft.nl/live/pagina.jsp?id=d94afef2-73a6-4a78-a609-

913141bbffc7\&lang=em>. Acesso em: 25 jan. 2007.

DEUTSCHES GEODÄTISCHES FORSCHUNGSINSTITUT. Regional Network Associate Analysis Centre for SIRGAS (IGS RNAAC SIR). Disponível em: <http://www.dgfi.badw.de/index.php?id=123>. Acesso em: 23 abr. 2007.

ENCYCLOPEDIA OF ASTROBIOLOGY ASTRONOMY AND SPACEFLIGHT. Galileo satellite navigation system. Disponível em:

<http://www.daviddarling.info/encyclopedia/G/Galileo satellite navigation.html>.

Acesso em: 23 abr. 2006.

EUROPEAN SPACE AGENCY. The future - GALILEO. Disponível em: $<$ http://www.esa.int/esaNA/GGGMX650NDC galileo 0.html>. Acesso em: 19 jun. 2006.

FAZAN, J. A. Controle de qualidade dos dados GPS da RBMC. Presidente Prudente: UNESP, 2002. 100 p. (Relatório Científico de Bolsa de Pesquisa de Iniciação Científica - FAPESP (Processo n.01/03145-2), correspondente ao período de Julho/2001 a Junho/2002). 
FEDERAL AVIATION ADMINISTRATION. Satellite navigation. Disponível em: <http://gps.faa.gov/>. Acesso em: 29 out. 2006.

FONSECA JR., E. S. O sistema GPS como ferramenta para a avaliação da refração ionosférica no Brasil. 2002. 176 f. Tese (Doutorado) - Escola Politécnica, Universidade de São Paulo, São Paulo, 2002.

FORTES, L. P. S. Operacionalização da rede brasileira de monitoramento contínuo do sistema GPS (RBMC). 1997. 152 f. Dissertação (Mestrado) - Instituto Militar de Engenharia, Rio de Janeiro, 1997.

.; GODOY, R. A. Z. Rede brasileira de monitoramento contínuo do sistema de posicionamento global - GPS. In: CONGRESSO BRASILEIRO DE CARTOGRAFIA, 15., 1991, Rio de Janeiro. Coletânea de trabalhos técnicos. Rio de Janeiro: SBC, 1991. v. 3, p. 677-682.

FREIBERGER JR., J. Análise da degradação do posicionamento em tempo real com o emprego do GNRT. 2002. 130 f. Dissertação (Mestrado) - Universidade Federal do Paraná, Curitiba, 2002.

GAMIT. Disponível em: <http://www-gpsg.mit.edu/ simon/gtgk/>. Acesso em: 20 mar. 2005.

GEMAEL, C.; ANDRADE, J. B. Geodésia celeste. Curitiba: Ed. UFPR, 2004. 389 p.

GEODETIC SURVEY DIVISION, NATURAL RESOURCES CANADA. CSRS - PPP. Disponível em: <http://www.geod.nrcan.gc.ca/>. Acesso em: 25 mar. 2005.

GIPSY-OASIS. Disponível em: <http://gipsy.jpl.nasa.gov/orms/goa/>. Acesso em: 14 mar. 2005.

HAN, S.; RIZOS, C. Improving the computational efficiency of the ambiguity function algorithm. Journal of Geodesy. v. 70, n. 6, p. 330-341. 1996.

HATANAKA, Y. Hatanaka format. Disponível em:

<http://gpsbase.nu.ac.za/ref/docs/hatanaka.htm>. Acesso em: 10 mar. 2005. 
HOFMANN-WELLENHOF, B.; LICHTENEGGER, H.; COLLINS, J. Global positioning system: theory and practice. $4^{\text {th }}$ rev. ed. Wien; New York: SpringerVerlag, c1997. xxii, $389 \mathrm{p}$.

HUGENTOBLER, U. (Ed.) et al. Bernese GPS software, version 5.0. Switzerland: Astronomical Institute, University of Bern, 2006. 548 p.

INSTITUTO BRASILEIRO DE GEOGRAFIA E ESTATÍSTICA. Especificações e normas gerais para levantamentos geodésicos (versão preliminar). Resolução da Presidência n. 5, de 31 março de 1993. Rio de Janeiro: IBGE, 1993. 18 p.

INSTITUTO BRASILEIRO DE GEOGRAFIA E ESTATÍSTICA. Geodésia. Disponível em: <http://www.ibge.gov.br/>. Acesso em: 22 dez. 2006.

INSTITUTO BRASILEIRO DE GEOGRAFIA E ESTATÍSTICA. Projeto mudança do referencial geodésico. Informativo geocêntrico, Rio de Janeiro, v. 2, n. 1, p. 4, 2003.

INSTITUTO GEOGRÁFICO NACIONAL. Curso avanzado de sistemas de posicionamiento por satélite. Madri, Espanha: IGN, 2006. 455 p.

INTERNATIONAL GNSS SERVICE. IGS - data and products. Disponível em: $<$ http://igscb.jpl.nasa.gov/>. Acesso em: 12 dez. 2006.

JET PROPULSION LABORATORY. Institute of Technology. AG - Auto Gipsy. Disponível em: <http://www.unavco.org/>. Acesso em: 23 mar. 2005.

KIM, D.; LANGLEY, R. B. GPS Ambiguity Resolution and Validation: Methodologies, Trends and Issues. $7^{\circ}$ GNSS Workshop - International Symposium on GPS/GNSS, Seul, Coréia, 2000. Disponível em: $<$ http://gauss.gge.unb.ca/papers.pdf/gnss2000.kim.pdf>. Acesso em: 08 fev. 2006.

LEICK, A. GPS satellite surveying. $2^{\text {nd }}$ ed. New York: John Wiley \& Sons, 1995. $587 \mathrm{p}$.

LIU, G. C. lonosphere weighted global positioning system carrier phase ambiguity resolution. 2001. 157 f. Dissertação (Mestrado) - University of Calgary, Canadá, 2001. 
LIU, J. Implementation and analysis of GPS ambiguity resolution strategies in single and multiple reference station scenarios. 2003. 149 f. Dissertação (Mestrado) - University of Calgary, Canadá, 2003.

MACHADO, W. C. Solução rápida das ambigüidades GPS para aplicações no posicionamento relativo de bases curtas. 2003. 126 f. Dissertação (Mestrado) Universidade Estadual Paulista, Presidente Prudente, 2002.

MONICO, J. F. G. Solução rápida das ambigüidades GPS utilizando o software GPSeq. In: XIX Congresso Brasileiro De Cartografia. Anais... CD-Rom. Recife/Olinda, 1999.

MARQUES, H. A.; SANTANA, M. R.; MONICO, J. F. G. Avaliação da qualidade das efemérides transmitidas dos satélites GPS. In: COLÓQUIO BRASILEIRO DE CIÊNCIAS GEODÉSICAS, 3., 2003, Curitiba. Novos desenvolvimentos em Ciências Geodésicas: anais. Curitiba : Curso de Pós-Graduação em Ciências Geodésicas, 2003. p. [pg.incial-pg.final].

MATSUOKA, M. T. Avaliação de funções para modelagem do efeito da refração ionosférica na propagação dos sinais GPS. 2003. 164 f. Dissertação (Mestrado) Universidade Estadual Paulista, Presidente Prudente, 2003.

McCARTHY, D. D. IERS standards. IERS technical note, Paris, n. 13, 1992, 150 p.

MICROCOSM. Van Martin Systems Inc. MicroCosm ${ }^{\circledR}$ software system. Disponível em: <http://www.vmsi-microcosm.com/index.html>. Acesso em: 22 mar. 2005.

MONICO, J. F. G. Métodos para solução da ambigüidade: primeiras experiências da UNESP de Presidente Prudente. In: GIS BRASIL 96. Anais... Curitiba, 1996. p. 465474.

Posicionamento pelo NAVSTAR-GPS: descrição, fundamentos e aplicações. São Paulo: Ed. UNESP, c2000. 287 p.

MORETTIN, P. A.; TOLOI, C. M. C. Previsão de séries temporais. 2. ed. São Paulo: Atual, 1987. 438 p.

.; BUSSAB, W.O. Estatística básica. 5. ed. São Paulo: Saraiva, 2006. 526 p. 
MUNDOGEO - Geoinformação para todos. Informações espaciais, tecnologia e desenvolvimento. Disponível em: <http://mundogeo.com.br>. Acesso em: 04 jan. 2006.

NIELL, A. E. Global mapping functions for the atmosphere delay at radio wavelengths. Journal of Geophysical Research, Washington, v. 101, n. B2, p. 3227-3246, 1996.

POLISCHUK, G. M. et al. The global navigation satellite system glonass:

development and usage in the $21^{\text {st }}$ century. In: ANNUAL PRECISE TIME AND TIME INTERVAL (PTTI) MEETING, 34., 2002, Reston, Virginia. Proceedings... Reston, Virginia: PTTI, 2002. p. 151-160. Disponível em:

<http://tycho.usno.navy.mil/ptti/ptti2002/paper13.pdf>. Acesso em: 23 abr. 2006.

RODRIGUES, D. D. Rede geodésica de precisão no estado de Minas Gerais: avaliação de diferentes estratégias de processamento e ajustamento. 2002. $116 \mathrm{f}$. Tese (Doutorado) - Escola Politécnica, Universidade de São Paulo, São Paulo, 2002.

ROTHACHER, M. et al. The swiss 1985 GPS campaign. In: INTERNATIONAL SYMPOSIUM ON SATELLITE POSITIONING, 4., 1986, Austin, Texas.

Proceedings... Austin, Texas, v. 2, p. 979-991, 1986.

ROYAL OBSERVATORY OF BELGIUM. Geodesy \& Geodynamics - GPS Dictionary. Disponível em: <http://www.gps.oma.be/gb/dic gb ok css.htm\#U $>$. Acesso em: 08 fev. 2007.

RUEGER, L. J. Development of receivers to characterize transit time and frequency signals. Johns Hopkins APL Technical Digest, Washington, v. 19, n. 01, p. 53-59, 1998.

SAASTAMOINEM, J. Contributions to the theory of atmospheric refraction. Bulletin geodesique, Toulouse, FR, n. 167, p. 13-34, 1973.

SANTOS, M. C. Impacto do $3^{\circ}$ sinal no GPS. InfoGeo, Curitiba, n. 15 , p. 22, 2000.

. NAVSTAR/GPS: aspectos teóricos e aplicações geofísicas. 1990. 162 f. Dissertação (Mestrado) - Observatório Nacional, Rio de Janeiro, 1990. 
SANTOS, M. S. T. Potencialidades do GPS em levantamentos geofísicos terrestres. 140 p. Dissertação (Mestrado) - Universidade de São Paulo (USP). São Paulo, 2005.

SCRIPPS COORDINATE UPDATE TOOL. SCOUT/SOPAC. Disponível em: <http://sopac.ucsd.edu>. Acesso em: 21 mar. 2005.

SEEBER, G. Satellite geodesy: foundations, methods and applications. $2^{\text {nd }}$ ed. Berlin; New York: Walter de Gruyter, 2003. 588 p.

SILVA, A. L. Estudo da distribuição e autocorrelação das observações GPS. 2005. 116 f. Dissertação (Mestrado) - Universidade Federal de Pernambuco, Recife, 2005.

SPIEGEL, M. R. Estatística. 3. ed. São Paulo: Makron, 1994. 643 p. (Coleção Schaum).

UNAVCO. Disponível em: <http://facility.unavco.org/software/teqc/teqc.html>. Acesso em: 12 set. 2006.

UNITED STATES NAVAL OBSERVATORY. USNO GPS timing operations. Disponível em: <http://tycho.usno.navy.mil/gps.html>. Acesso em: 30 dez. 2006.

WIKIPEDIA. A enciclopédia livre. Disponível em: <http://www.wikipedia.org/>. Acesso em: 12 dez. 2006. 


\section{ANEXO A - Arquivo de Saída do Programa TEQC}

A seguir, é mostrado parte de um arquivo de saída (.XXS) gerado pelo programa TEQC para o dia 13 de janeiro de 2003.

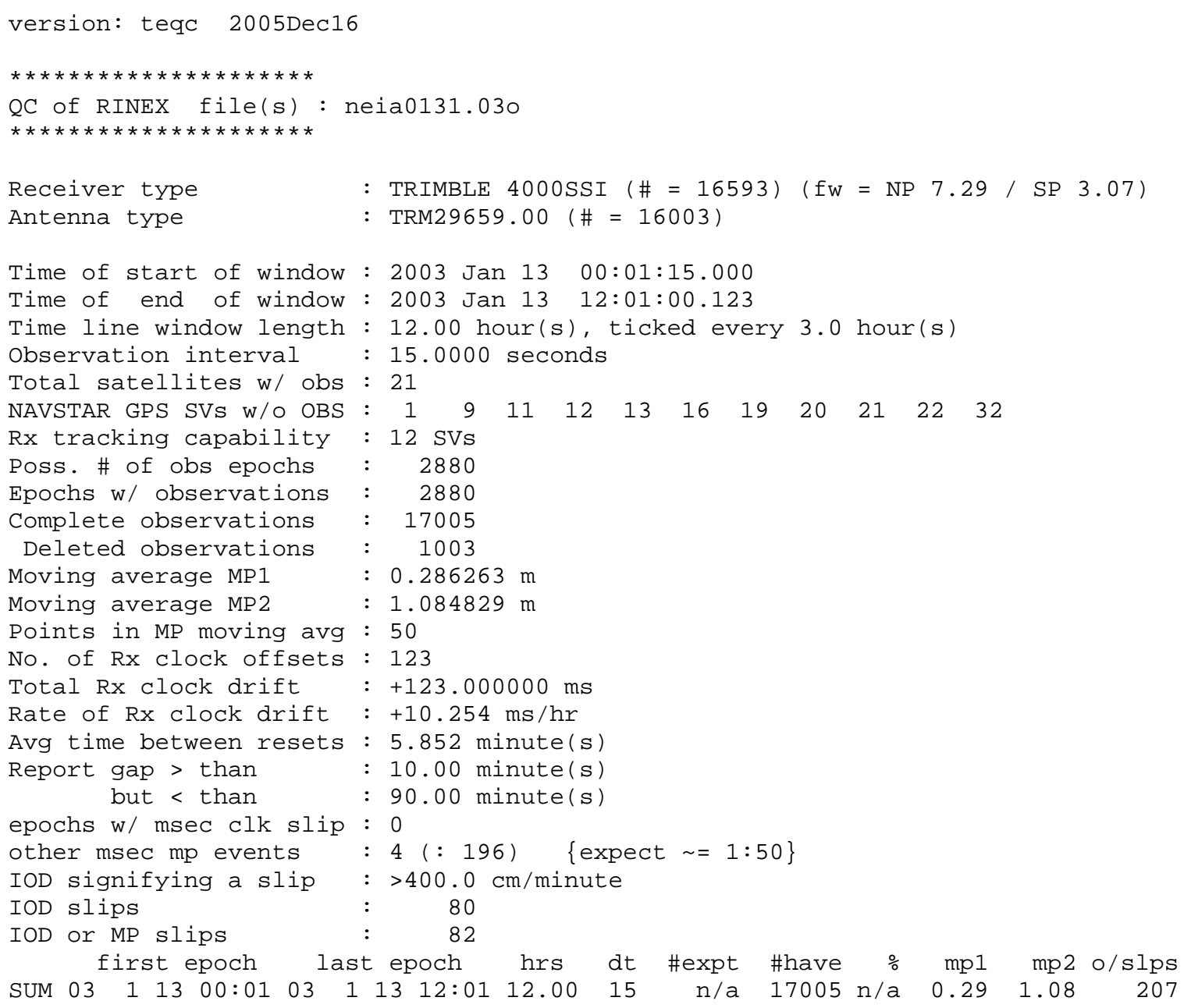

